\title{
Weer aan het werk : verzekeringsgeneeskundige verzuimbegeleiding als onderhandeling over verantwoordelijkheden
}

Citation for published version (APA):

Meershoek, A. M. (1999). Weer aan het werk : verzekeringsgeneeskundige verzuimbegeleiding als onderhandeling over verantwoordelijkheden. [Doctoral Thesis, Maastricht University]. Thela Thesis. https://doi.org/10.26481/dis.19990702am

Document status and date:

Published: 01/01/1999

DOI:

10.26481/dis.19990702am

Document Version:

Publisher's PDF, also known as Version of record

Please check the document version of this publication:

- A submitted manuscript is the version of the article upon submission and before peer-review. There can be important differences between the submitted version and the official published version of record. People interested in the research are advised to contact the author for the final version of the publication, or visit the DOI to the publisher's website.

- The final author version and the galley proof are versions of the publication after peer review.

- The final published version features the final layout of the paper including the volume, issue and page numbers.

Link to publication

\footnotetext{
General rights rights.

- You may freely distribute the URL identifying the publication in the public portal. please follow below link for the End User Agreement:

www.umlib.nl/taverne-license

Take down policy

If you believe that this document breaches copyright please contact us at:

repository@maastrichtuniversity.nl

providing details and we will investigate your claim.
}

Copyright and moral rights for the publications made accessible in the public portal are retained by the authors and/or other copyright owners and it is a condition of accessing publications that users recognise and abide by the legal requirements associated with these

- Users may download and print one copy of any publication from the public portal for the purpose of private study or research.

- You may not further distribute the material or use it for any profit-making activity or commercial gain

If the publication is distributed under the terms of Article $25 \mathrm{fa}$ of the Dutch Copyright Act, indicated by the "Taverne" license above, 


\section{WEER AAN HET WERK}


HSTYY TIIII YAAR GHaW 


\section{WEER AAN HET WERK}

Verzekeringsgeneeskundige verzuimbegeleiding als onderhandeling over verantwoordelijkheden

\section{PROEFSCHRIFT}

ter verkrijging van de graad van doctor aan de Universiteit Maastricht,

op gezag van de Rector Magnificus, Prof. dr. A.C. Nieuwenhuijzen Kruseman volgens het besluit van het College van Decanen,

in het openbaar te verdedigen

op vrijdag 2 juli 1999 om 14.00 uur

door

Agnes Maria Meershoek

geboren op 25 februari 1967

te Losser 


\section{Promotores:}

Prof. dr. G.A.M. Widdershoven

Prof. dr. ir. W.E. Bijker

Prof. dr. F.J.N. Nijhuis

\section{Beoordelingscommissie:}

Prof. dr. R. Vos

Dr. mr. J.C.J. Dute

Prof. dr. A. Mol (Universiteit Twente)

Prof. dr. H. Philipsen

Prof. dr. R.J. van der Veen (Universiteit Twente) 


\section{Inhoud}

Voorwoord

1. Poortwachters van de arbeidsongeschiktheidsregelingen

- onderzoek naar verzekeringsgeneeskundig handelen in de praktijk -

1 Inleiding

2 Bewaken van de toegang 11

3 Oordelen en kennis 13

4 Flexibele criteria $\quad 15$

5 Onderhandelen $\quad 16$

$\begin{array}{ll}6 \text { Logica's van praktijken } & 20\end{array}$

2. Verzekeringsartsen en de Ziektewet 29

1 Inleiding 29

2 Wetgeving en uitvoeringsorganisaties $\quad 31$

3 Proceduregang binnen de BVG $\quad 34$

4 Opzet, methode en analyse $\quad 41$

3. Wat vindt u er zelf van? 47

- de constructie van de zieke als werknemer -

1 Inleiding 47

2 Het voorstel voor een rolverdeling $\quad 48$

3 De werkhervatting als probleem van de cliënt $\quad 50$

4 Van praten over, naar doen: het werk hervatten $\quad 57$

5 Vertrouwen geven of reguleren $\quad 66$

$\begin{array}{ll}6 \text { Conclusie } & 72\end{array}$

4. De behandelaar op afstand $\quad 77$

- de constructie van het verzekeringsgeneeskundig domein -

1 Inleiding $\quad 77$

2 Ziekte naast werkhervatting $\quad 78$

3 Samenvallende domeinen $\quad 90$

4 Conclusie $\quad 99$ 
5. Werkgevers als spil in de verzuimbegeleiding

- de constructie van een gezonde arbeidsrelatie -

1 Inleiding

2 De werkhervatting als probleem van de werkgever 106

3 Werkgevers als probleem $\quad 120$

4 Conclusie 131

$\begin{array}{lr}\text { 6. Conclusie } & 135\end{array}$

1 Inleiding 135

2 De logica van de verzekeringsgeneeskundige praktijk 135

3 Logica's van praktijken $\quad 140$

4 Normativiteit van praktijken $\quad 143$

5 Besluit 147

$\begin{array}{lr}\text { Literatuur } & 153\end{array}$

$\begin{array}{ll}\text { Summary } & 161\end{array}$ 


\section{Voorwoord}

Toen ik begin jaren ' 90 begon aan het onderzoek waar dit boek verslag van doet, stonden de Ziektewet en de WAO nog nauwelijks in de politieke schijnwerpers. Sindsdien is er veel gebeurd. Ziektewet en WAO hebben onder invloed van politieke ontwikkelingen drastische wijzigingen ondergaan en in de loop der jaren menig krantenpagina gevuld. Maar niet alleen 'het veld' was onrustig, ook de relatie tussen mij en m'n onderzoeksonderwerp heeft woelige tijden gekend.

Waar het schrijven van een proefschrift vaak vergeleken wordt met een (zware) bevalling, is voor mij een vergelijking van deze periode met volwassen worden meer to the point. Naast een zoektocht binnen het domein van onderzoek hebben de afgelopen jaren zich gekenmerkt door een zoeken naar een plaats in 'de wereld'. Zowel binnen de wetenschap als daarbuiten. Periode van euforie hebben zich afgewisseld met soms diepe dalen. Dat ik uiteindelijk met plezier en voldoening op deze periode terug kijk komt door de steun die ik van velen heb gehad.

Op de eerste plaats gaat mijn dank uit naar mijn drie promotoren. Mijn soms grillige buien hebben ze geduldig laten overwaaien, en ze hebben me de ruimte gegeven om mijn eigen positie te zoeken en het werk in mijn eigen tempo te voltooien. De laatste jaren heeft Guy Widdershoven mij regelmatig gewezen op de implicaties van mijn soms kort door de bocht getrokken conclusies. De discussies met hem waren vaak waardevol en maakten het mogelijk om de analyses te nuanceren en aan te scherpen. Wiebe Bijker heeft een belangrijke rol gespeeld bij het vergroten van mijn psychische draagkracht. Hij was nooit te beroerd om over weer een nieuwe opzet van het boek of een hoofdstuk te brainstormen. En zijn vertrouwen in een goede afloop heeft mij gesterkt. Frans Nijhuis kende (en kent) vooral het 'veld' terwijl de onderzoeksbenadering die ik koos wat verder van hem afstond. De begeleidingsgesprekken mondden dan ook vaak uit in het vrij discussieren over ontwikkelingen in de arbeidsongeschiktheidsregelingen. Deze discussies, maar ook zijn enthousiasme voor de resultaten die 'dit type' onderzoek opleverde zijn voor mij een belangrijke stimulans geweest.

Discussies met vakgenoten binnen het verband van Loowtok, ZTC en Bots zijn belangrijk geweest bij het uitdenken van lijnen. Zowel het bespreken van mijn eigen werk als dat van anderen hebben veel inspiratie gebracht. Ook de aio-soep was in dit verband van grote waarde. Maar meer nog dan de inhoudelijke bijdrage die mijn mede aio's in Maastricht leverden, heeft het delen van de lusten en lasten die gepaard gaan met het aio-bestaan, me veel plezier opgeleverd. Een speciale rol in dit geheel heeft Anja Krumeich gespeeld. Ze was steeds weer bereid om verhalen aan te horen over de nieuwe vondsten die ik had gedaan en het zoveelste concept van een hoofdstuk te lezen. Discussies met haar hebben een grote stempel op dit boek gedrukt. Anja, ik hoop deze samen- 
werking in de toekomst voort te kunnen zetten. Ruud Hendriks, Saskia van der Lyke, Antoinette de Bont, Roland Bal, Marc Berg, Klasien Horstman en Marie-Josée Smits hebben in eerdere of latere stadia het manuscript of delen daaruit voorzien van commentaar. Hun suggesties hebben de uiteindelijke tekst aanzienlijk verbeterd.

Dank ook aan Wout de Boer, die mij toegang tot het veld verschafte. Zonder de medewerking van de verzekeringsartsen binnen de BVG had het onderzoek niet kunnen plaatsvinden. Ik heb het zeer op prijs gesteld dat zij mij met grote openheid hun spreekkamers hebben binnen gelaten. Dat zelfde geldt voor de medewerking van cliënten.

Judith Ruijs, Hannerieke van der Boom en Carola Koornneef hebben mij met het verzamelen van relevante literatuur veel werk uit handen genomen. Ingrid Lathouwer is bereid geweest de opmaak van het manuscript te verzorgen en Ruth Benschop om de engelse samenvatting te corrigeren. Allen dank daarvoor.

De vakgroep Gezondheidsethiek en Wijsbegeerte fungeerde al die jaren als mijn 'thuisbasis'. De leden van deze vakgroep hebben mijn dagelijkse werkomgeving tot een zeer plezierige gemaakt. Marleen Goumans, waarmee ik gedurende enkele jaren een kamer deelde, is daarbij een aparte vermelding waard. Haar luisterend oor voor zowel inhoudelijke ideeën, dagelijkse tegenslag als grootse nieuwe plannen was geweldig.

Tenslotte wil ik mijn ouders bedanken voor het vertrouwen dat ze al die jaren in mij hebben gesteld.

Agnes Meershoek

Maastricht 21-4-'99 


\section{Poortwachters van de arbeidsongeschiktheidsregelingen}

- onderzoek naar verzekeringsgeneeskundig handelen in de praktijk -

\section{Inleiding}

Sinds eind vorige eeuw de eerste wetten op het terrein van de sociale verzekeringen werden geintroduceerd, hebben artsen een belangrijke rol gespeeld bij de ontwikkeling van de verzorgingsstaat. De aanwezigheid van artsen in dit domein wordt gelegitimeerd door het feit dat ziekte in een deel van deze wetgeving het toelatingscriterium vormt waarop beoordeeld wordt of iemand rechtmatig een beroep doet op een uitkering. Aan het begin van deze eeuw gold dat voor de Ongevallenwet (1901), de Invaliditeitswet (1913) en later voor de Ziektewet (1930). Op dit moment spelen artsen nog steeds een belangrijke rol bij beoordelingen in het kader van de arbeidsongeschiktheidsregelingen (Wet op de Arbeidsongeschiktheid, WAO; Wet Arbeidsongeschiktheidsverzekering zelfstandigen, WAZ; Wet Arbeidsongeschiktheidsvoorziening jonggehandicapten, Wajong; Ziektewet, ZW).

Alhoewel het werk dat artsen in het kader van de arbeidsongeschiktheidsregelingen uitvoeren door het ziektecriterium binnen het geneeskundig domein wordt gebracht, verschilt de taak van verzekeringsartsen' sterk van die van andere artsen. Althans van de taak waarmee artsen normaal gesproken geassocieerd worden, namelijk het therapeutische werk ${ }^{2}$. Deze domeinscheiding binnen de geneeskunde hangt samen met de zogenaamde scheiding van behandeling en controle. De taak van verzekeringsartsen ${ }^{3}$ is namelijk niet in de eerste plaats gericht op genezing, maar op controleren. Verzekeringsartsen vervullen een poortwachtersfunctie voor sociale voorzieningen, die er uit bestaat te controleren of zieke werknemers rechtmatig een beroep doen op de voorzieningen van $\mathrm{ZW}$ en WAO.

De maatschappelijke betekenis van deze poortwachtersfunctie van artsen is groot. Niet alleen zijn de financiële stromen die in deze sector omgaan aanzienlijk ${ }^{4}$, artsen hebben in deze poortwachtersfunctie een belangrijke stem in het reguleren van maatschappelijke verhoudingen. Door het ziektecriterium in de arbeidsongeschiktheidsregelingen wordt de bevoegdheid om mensen (tijdelijk) te ontheffen van hun normale maatschappelijke plichten voor een groot deel in de handen van artsen gelegd en hebben zij een belangrijke stem bij het bepalen wie wel en wie geen recht heeft op een uitkering (De Swaan, 1983).

Ondanks de maatschappelijke betekenis van het werk van verzekeringsartsen is de belangstelling voor hun werk historisch gezien relatief gering. Binnen het sociaal-wetenschappelijk onderzoek zijn slechts enkele studies die het werk van verzekeringsartsen tot 
onderwerp hebben. Ook in de politieke context is pas zeer recent aandacht voor de positie van verzekeringsartsen. Medische advisering werd beschouwd als een zaak van de beroepsgroep zelf. Artsen zijn op grond van hun expertise ingeschakeld bij deze arrangementen. Die expertise legitimeert niet alleen de aanwezigheid van artsen in deze context, maar verschaft hen tevens een grote mate van autonomie. Dat wil zeggen dat ook het toezicht op de wijze waarop artsen deze rol vervullen voor een groot deel in handen van de beroepsgroep zelf is.

Sinds de parlementaire enquête naar de sociale zekerheid (Tweede Kamer, 1992) en de wetswijzigingen die daar op volgden mogen deze poortwachters zich verheugen in enige publieke en politieke belangstelling. En ook in het wetenschappelijk onderzoek zijn begin jaren ' 90 een aantal studies verschenen die het handelen van verzekeringsartsen in de praktijk van de uitvoering van $\mathrm{ZW}$ en WAO tot onderwerp hebben ${ }^{5}$. Met deze belangstelling wordt de rol van artsen bij de uitvoering van de arbeidsongeschiktheidsregelingen ook steeds meer onderwerp van discussie. Met name in het publieke en politieke domein wordt forse kritiek geuit op het functioneren van artsen in deze context. In de parlementaire enquête sociale zekerheid wordt bijvoorbeeld geconcludeerd dat artsen hun oren teveel laten hangen naar de politieke wensen van werkgevers en werknemers, die hen via het bestuur van de uitvoeringsorganisaties aanmoedigen om vooral soepel op te treden $^{6}$. Het vellen van objectieve en onafhankelijke oordelen op basis van hun expertise zou daardoor sterk bemoeilijkt worden. Bovendien zouden artsen zich in hun oordeelsvorming te veel laten leiden door informele regels en professionele normen die een strikte toepassing van de wet in de weg staan.

Deze kritiek op artsen is voor een belangrijk deel gebaseerd op de constatering dat het praktisch handelen van verzekeringsartsen geen afspiegeling vormt van de theoretische ideeën die daarover bestaan. In plaats van hun oordelen te baseren op objectieve kennis zouden artsen zich laten leiden door bijvoorbeeld politieke belangen, en in plaats van oordelen te vellen aan de hand van formele beslisregels zouden ze zich in hun oordeelsvorming laten beïnvloeden door hun cliënten en allerhande niet-medische factoren. Of deze kritiek nu terecht is of niet, er ligt wel een belangrijke veronderstelling aan ten grondslag; de veronderstelling dat theoretische principes de basis vormen voor praktisch handelen. Volgens deze critici blijkt echter dat die principes in de praktijk worden vertroebeld door andere zaken. Een dergelijke veronderstelling over de relatie tussen theoretische principes en praktisch handelen is door diverse wetenschappelijke disciplines geproblematiseerd. In het wetenschapsonderzoek en de ethnomethodologie wordt er voor gepleit om praktisch handelen of de praktijk niet te beschouwen als een afgeleide van principes, maar als een zelfstandig domein dat haar eigen logica of praktische rationaliteit kent'. In dit onderzoek zal de verzekeringsgeneeskundige praktijk van de uitvoering van de ziektewet vanuit die aanname onderzocht worden. De centrale vraag luidt dan ook 
welke logica in het verzekeringsgeneeskundig handelen in de praktijk is aan te wijzen, of anders gezegd, hoe de verzekeringsgeneeskundige praktijk geordend is.

Die logica of ordening heeft het karakter van een praktische rationaliteit. Dat betekent dat ze tot stand komt in de onderhandelingen tussen betrokken actoren in de praktische setting. In dit onderzoek zal de aandacht dan ook uitgaan naar alledaagse gesprekssituaties in de verzekeringsgeneeskundige praktijk. Gesprekken tussen verzekeringsartsen en cliềnten, die daar een belangrijk onderdeel van vormen, zullen gedetailleerd geanalyseerd worden.

In dit eerste hoofdstuk zal ik de achtergrond van de vraagstelling en het theoretisch perspectief dat in deze studie gehanteerd wordt nader uiteenzetten. Daartoe begin ik met een korte karakterisering van de formele rol van verzekeringsartsen die werkzaam zijn in het kader van de arbeidsongeschiktheidsregelingen en ga ik in op de wijze waarop de beoordeling daarbinnen wordt geconceptualiseerd. Vervolgens zal ik ingaan op een aantal verklaringen die in onderzoek naar de verzekeringsgeneeskundige praktijk gegeven worden voor het feit dat het handelen in de praktijk niet overeenkomt met de theoretische principes en tevens aannemelijk maken dat deze verklaringen slechts ten dele bevredigend zijn wanneer men van het standpunt uitgaat dat praktisch handelen een eigen logica kent. Tenslotte zal ik het theoretische perspectief schetsen dat in deze studie gehanteerd zal worden.

\section{Bewaken van de toegang}

Volgens Deborah Stone (1984) dragen sociale verzekeringen, hoe verschillend ook in hun verschijningsvormen, een spanningsveld in zich". De primaire gedachte achter stelsels van sociale zekerheid is het besef dat de maatschappij een bepaalde verantwoordelijkheid draagt voor mensen die niet in hun eigen bestaansvoorwaarden kunnen voorzien. Sociale verzekeringen regelen een redistributie van inkomens. Degenen die recht hebben op de voorzieningen die de verzekering regelt, krijgen bepaalde privileges, in de vorm van geldelijke toelagen en/of vrijstellingen van normale plichten van een burger, zoals bijvoorbeeld werken. Die geprivilegieerde positie wordt gerechtvaardigd door het feit dat deze mensen, buiten hun eigen schuld, behoeftig zijn. De niet-behoeftigen brengen gezamenlijk de kosten voor deze voorzieningen op. Om het systeem in stand te houden is het noodzaak dat de groep van behoeftigen niet te groot wordt. Dat gevaar bedreigt systemen van sociale zekerheid voortdurend. Enerzijds omdat 'behoeftig zijn' slechts ten dele een van nature gegeven, maar vooral een maatschappelijk bepaalde conditie is. Anderzijds omdat het stelsel bepaalde privileges toekent, waardoor het een aantrekkingskracht uitoefent op niet-behoeftigen. 
$\mathrm{Om}$ te voorkomen dat het systeem van sociale zekerheid overvoerd raakt, worden criteria opgesteld waaraan mensen moeten voldoen om te worden toegelaten. Historisch onderzoek laat zien dat die criteria in de loop der tijd aan veranderingen onderhevig zijn geweest. De introductie van het criterium 'ziekte' als maatstaf om behoeftigheid vast te stellen, dateert van de tweede helft van de vorige eeuw. Dat het ziekte-criterium werd verkozen boven andere criteria, hing samen met de verwetenschappelijking van de geneeskunde. Binnen de geneeskunde werden technieken en methoden geïntroduceerd die de belofte in zich hielden om mensen aan een onderzoek te onderwerpen, zonder dat de arts zich op het verhaal van de patiënt zou moeten verlaten. "..technological development of instruments to give the physician information about the body and its processes without his having to rely on the patiënt's description of himself" (Stone, 1984, 104). Artsen zouden met behulp van deze technieken feitelijke ongeschiktheid en geveinsde ongeschiktheid van elkaar kunnen onderscheiden?. Tot op de dag van vandaag wordt de aanwezigheid van artsen gelegitimeerd door de veronderstelling dat zij met behulp van hun expertise $^{10}$ op het gebied van ziekte in staat zijn een objectief oordeel uit te spreken over de mate van behoeftigheid van mensen die een beroep doen op die verzekeringen.

In de formele omschrijving of de standaardopvatting van de rol van verzekeringsartsen als poortwachters wordt hun werk gekarakteriseerd door het vellen van objectieve oordelen. Objectief in de zin dat de arts beschikt over algemeen geldende criteria waarop cliënten beoordeeld worden èn over een instrumentarium waarmee de 'toestand' van de cliënt kan worden vastgesteld zonder dat de cliënt daar invloed op kan uitoefenen. Die objectiviteit zou een uniforme behandeling van cliënten kunnen garanderen, in de zin dat gelijke gevallen gelijk behandeld zullen worden. En die uniformiteit is nodig om rechtsgelijkheid te garanderen (Tweede Kamer, 1992; Croon en Langius, 1993; Van Eck, 1990)". In deze conceptualisering van de arbeidsongeschiktheidsbeoordeling wordt het besluitvormingsproces als een formeel en rationeel proces opgevat (Van der Veen, 1990; Berg, 1997). Dat wil zeggen dat verondersteld wordt dat beslissingen logisch voortvloeien uit het toepassen van expliciete regels op concrete situaties. Voor er iets kan worden beslist moet in eerste instantie de toestand van de cliënt wordt vastgesteld. In het kader van de arbeidsongeschiktheidsregelingen zou medische kennis de garantie geven dat de conditie van de cliënt objectief in kaart wordt gebracht. $\mathrm{Na}$ die inventarisatie wordt op basis van een logische afleiding uit criteria en regels een besluit genomen.

Zowel door verzekeringsartsen zelf, als in het publieke debat, als in onderzoek naar de verzekeringsgeneeskundige praktijk wordt gesignaleerd dat de wijze waarop arbeidsongeschiktheidsoordelen in de praktijk tot stand komen, niet strookt met de standaardopvatting over de taak van verzekeringsartsen. De precieze verklaring daarvoor en de consequenties die daaraan verbonden moeten worden, lopen echter sterk uiteen. In de rest van dit hoofdstuk zal ik deze verklaringen bespreken. Op de eerste plaats zal ik ingaan op een verklaring die verzekeringsartsen zelf geven voor het feit dat zij in de praktijk op 
een andere wijze besluiten nemen dan volgens de theoretische principes verondersteld wordt. Binnen de kring van verzekeringsartsen wordt dit 'falen' geweten aan een gebrek aan kennis, alhoewel sommige verzekeringsartsen wijzen op de onmogelijkheid om in het kader van de arbeidsongeschiktheidsregelingen objectieve oordelen te vellen op basis van kennis. Vervolgens komen verschillende sociologische verklaringen aan bod. Daarbij zal ik ingaan op de analyse van Stone, waarin centraal staat dat het arbeidsongeschiktheidscriterium geen strikt maar een flexibel karakter heeft. Door het hanteren van een dergelijk criterium staat de restrictiviteit van de toelating van mensen tot de arbeidsongeschiktheidsregelingen in de praktijk voortdurend onder druk. Ten derde zal ik ingaan op een aantal empirische studies naar het werk van verzekeringsartsen, die in het verlengde van de conclusies van Stone, laten zien dat het besluitvormingsproces ten aanzien van arbeidsongeschiktheid geen formeel-rationeel karakter heeft, gebaseerd op het ziektecriterium, maar een contextueel karakter waarbij cliënten niet zozeer een passieve positie innemen, maar het besluitvormingsproces eerder het karakter van een onderhandeling heeft. Het hoofdstuk wordt afgesloten met een bespreking van het perspectief dat in deze studie centraal zal staan.

\section{Oordelen en kennis}

Sinds de invoering van de WAO eind jaren '60 wordt in verzekeringsgeneeskundige kring de groei van het aantal arbeidsongeschikten geproblematiseerd (Meershoek, 1993; Josten, 1974, 1978; Weijel, 1973; Mertens, 1974; Zaal, 1978; Hilverinck, 1978). Verzekeringsartsen zien het problematische karakter van het arbeidsongeschiktheidscriterium als een van de belangrijkste oorzaken van die groei. Sommige verzekeringsartsen wijzen er in de jaren ' 70 , vlak na de invoering van de WAO, op, dat het ziektebegrip steeds omvattender is geworden. Naast lichamelijk onwelbevinden is het steeds meer geaccepteerd geworden om ook geestelijk en maatschappelijk onwelbevinden als een kwestie van gezondheid en ziekte te beschouwen (Gentis, 1972). Omdat het moeilijk was ongeschiktheid door ziekte en ongeschiktheid door andere oorzaken te onderscheiden, was het voor verzekeringsartsen moeilijk om de grens tussen ziekte en ongeschiktheid enerzijds en gezond en geschikt anderzijds te trekken. Sommige verzekeringsartsen zagen de groei van het aantal arbeidsongeschikten dan ook als een gevolg van veranderende waarden en normen in de maatschappij, waarbij verzekeringsartsen tot taak hadden mensen met al deze problemen te helpen (Weijel, 1970; Festen, 1970). Anderen waren echter van mening dat verzekeringsartsen zich moesten houden aan de wettelijke taakstelling en, tegen de maatschappelijke ontwikkelingen in, vast moesten houden aan een strikt uit ziekte afgeleid arbeidsongeschiktheidscriterium (Van der Beek, 1974). Daartoe zouden de begrippen ziekte en ongeschiktheid beter gedefinieerd moeten worden. 
In de jaren ' 80 wordt de roep om een strikte invulling van de wettelijke taak, waarin het gaat om het vaststellen van ziekte en het aangeven van de gevolgen daarvan voor het uitoefenen van arbeidsfuncties, luider. Timmer, de eerste bijzonder hoogleraar verzekeringsgeneeskunde, constateert echter dat het ongeschiktheidscriterium dat in de wet wordt gegeven, in de praktijk moeilijk te hanteren is, omdat verzekeringsgeneeskundige kennis over de relatie tussen ziekte en arbeidsongeschiktheid ontbreekt (Timmer, 1985). Verzekeringsartsen zouden zich in de praktijk te veel laten leiden door intuïties in plaats van door objectieve kennis. Volgens Timmer en anderen is dat bezwaarlijk omdat in een intuïtieve afweging makkelijk ruimte gegeven kan worden aan argumenten die misschien redelijk, maar niet objectief zijn (zie ook Hunfeld, 1984; Saan, 1981). Een intuïtieve afweging is dan ook niet verantwoord omdat ze geen rechtsgelijkheid kan garanderen. 'Dit constaterende zullen we niet moeten besluiten dan maar de zaak te laten zoals ze is, doch proberen onze ziektecriteria zo goed mogelijk te formuleren en te uniformeren' (Saan, 1981, 693). Timmer heeft het initiatief genomen het zogenaamde verzekeringsgeneeskundig referentiekader te ontwikkelen waarbinnen dergelijke kennis gegenereerd kan worden. In dit referentiekader wordt het verzekeringsgeneeskundig besluitvormingsproces opgesplitst in een aantal stappen. Eerst moet een bepaalde ziekte of gebrek worden vastgesteld. Uit die ziekte wordt vervolgens afgeleid welke stoornissen iemand heeft, om op grond van die stoornissen te bepalen over welke vaardigheden iemand nog beschikt. Een confrontatie tussen vaardigheden en werkuitvoeringseisen maakt duidelijk welke arbeidsfuncties iemand nog kan vervullen. Een formalisering van het besluitvormingsproces op basis van kennis over ziekte-eenheden en de relatie tussen ziekte en functioneren zou het verzekeringsgeneeskundig besluitvormingsproces doorzichtig en objectief kunnen maken $^{12}$.

Tegen deze objectiverende opvatting over het vellen van arbeidsongeschiktheidsoordelen is in verzekeringsgeneeskundige kring veel bezwaar gemaakt (Herngreen, 1985; Knepper, 1989). Opponenten van Timmer voeren als kritiek aan dat Timmer ziekte als objectieve toestand beschouwt, terwijl ziekte en met name de mate waarin ziekte leidt tot arbeidsongeschiktheid volgens deze verzekeringsartsen een persoonsgebonden en dynamische aangelegenheid is. De klachten en het functioneren van een persoon zijn niet rechtstreeks af te leiden uit de diagnose omdat elk individu ziekte anders ervaart. De ene persoon met griep heeft daar minder last van dan de andere, de een wordt erdoor belemmerd in zijn functioneren en de andere niet. Bovendien wordt het vaststellen van arbeidsongeschiktheid bemoeilijkt omdat de definitie gekoppeld is aan de werkzaamheden die iemand uitvoert. Deze verzekeringsartsen stellen voor om niet de objectiviteit maar de plausibiliteit van het verhaal van de cliënt centraal te stellen in de arbeidsongeschiktheidsbeoordeling. Deze verzekeringsartsen hebben eveneens een beoordelingsmethodiek ontwikkeld: de zogenaamde argumentatieve claimbeoordeling. Verzekeringsartsen die volgens deze methode werken beoordelen niet zozeer of een ziekte objectief aanwezig is, 
maar of de werknemers aannemelijk maken dat zij niet kunnen functioneren ${ }^{13}$ (De Boer, 1988, 1992). De verzekeringsarts bekleedt volgens deze auteur vooral de rol van rechter waar het zijn beoordelingstaak betreft. De rechtmatigheid van de oordelen die hij velt, wordt gewaarborgd door zijn neutrale positie, van waaruit hij beoordeelt of de cliënt de waarheid spreekt.

Dat verzekeringsartsen in de praktijk geen oordelen vellen op basis van een formeel beslissingsmodel, met ziekte als criterium voor toelating, wordt door verzekeringsartsen dus op verschillende manieren verklaard. Sommige verzekeringsartsen zien de handelwijze in de praktijk als een falen van verzekeringsartsen, dat veroorzaakt wordt door gebrekkige kennis over de relatie tussen ziekte en ongeschiktheid. Anderen wijzen op de onmogelijkheid van het vellen van objectieve oordelen op basis van medische kennis en stellen daarvoor het criterium plausibiliteit in de plaats. Ook bij deze laatste groep wordt de oordeelsvorming echter geconceptualiseerd als een besluitvormingsproces, waarbij de toestand van de cliënt moet worden geinnventariseerd om vervolgens tot een oordeel te komen. Het criterium waarop wordt beoordeeld is echter niet objectief aantoonbare ziekte, maar plausibiliteit van het verhaal van de cliënt. Daarin worden onder andere de aannemelijkheid van de klachten gezien het ziektebeeld, en de consistentie van het verhaal van de cliënt in ogenschouw genomen. Deze twee stromingen zijn nog steeds binnen de verzekeringsgeneeskunde te onderscheiden (De Bont e.a., 1998).

\section{Flexibele criteria}

Ook in sociologisch onderzoek naar de poortwachtersfunctie van artsen bij de arbeidsongeschiktheidsregelingen wordt het formeel-rationele model van besluitvorming, waarbij oordelen op basis van kennis en wettelijke voorschriften tot stand komen, geproblematiseerd. Dat beoordelingen in het kader van de arbeidsongeschiktheidsregelingen in de praktijk minder restrictief zijn dan in regelgeving beoogd wordt, komt volgens Stone (1984) doordat het 'ongeschiktheidscriterium' een grote mate van flexibiliteit kent. Die flexibiliteit komt voort uit het feit dat ziekte en arbeidsongeschiktheid geen objectief vaststelbare grootheden zijn. Ongeschiktheid tot werken is niet meetbaar met medischdiagnostische middelen omdat medisch-diagnostische middelen zelf niet betrouwbaar zijn, omdat ze gevoelig zijn voor manipulatie door betrokkenen en omdat arbeidsongeschiktheid niet direct afleidbaar is uit medische toestand maar tevens bepaald wordt door maatschappelijke normen, bijvoorbeeld ten aanzien van de vraag welke inspanningen en welke pijndrempels van mensen verwacht mogen worden. De medisch-diagnostische informatie die artsen ter beschikking staat bij de arbeidsongeschiktheidsbeoordeling vormt daarmee niet de basis van een logisch-deductieve afleiding voor het vaststellen van arbeidsongeschiktheid, maar vormt een element dat artsen meewegen in hun beslis- 
sing of iemand al dan niet arbeidsongeschikt is. Gezien de flexibiliteit van het arbeidsongeschiktheidscriterium wordt deze beslissing mede beïnvloed door alledaagse normen ten aanzien van ziekte en arbeidsongeschiktheid, die een minder restrictief karakter hebben dan de formele. In de opvatting van Stone is de arbeidsongeschiktheidsbeoordeling dan ook geen formeel-rationeel proces.

Waar Timmer het feit dat verzekeringsartsen in de praktijk geen formeel-rationele besluiten nemen wijt aan een op te heffen tijdelijk gebrek aan medische kennis, laat Stone overtuigend zien dat medische kennis ten principale geen garantie kan geven voor formeel-rationele besluiten. Die kennis is per definitie niet volledig en bovendien is voor het toepassen van kennis interpretatie nodig. Die interpretatie is afhankelijk van culturele waarden en normen, onder andere ten aanzien van wat binnen een samenleving telt als ziek en wat niet. Het feit dat medische kennis geen basis kan vormen voor objectieve rationele oordelen leidt er volgens Stone toe dat arbeidsongeschiktheidsoordelen mede gebaseerd worden op culturele en professionele normen en waarden en dat ze gevoelig zijn voor manipulatie door cliënten en artsen. Stone's analyse handelt over de politieke consequenties van deze constatering. Ze stelt dat sommige (groepen) cliënten meer mogelijkheden tot hun beschikking hebben om de beoordeling te beïnvloeden dan anderen en dat daardoor de mogelijkheden om toegang tot arbeidsongeschiktheidsregelingen te krijgen voor verschillende cliënten verschillend zijn (zie ook Stone, 1979). Hoe die culturele normen en waarden in de dagelijks beoordelingspraktijk van verzekeringsartsen zijn ingebed en leiden tot ongelijke kansen valt echter buiten het domein van haar onderzoek.

\section{Onderhandelen}

Vanaf begin jaren ' 90 zijn er vanuit de onderzoeksafdelingen van het Gemeenschappelijk Administratie Kantoor (GAK) en de Gemeenschappelijke Medische Dienst (GMD) een aantal studies verschenen waarin juist het handelen van verzekeringsartsen in de praktijk op micro-niveau centraal staat (Razenberg, 1992; Van Eck, 1990; Croon en Langius, 1993). Ook deze onderzoekers concluderen dat het voor verzekeringsartsen vaak onmogelijk blijkt om de toestand van een cliënt in medisch objectieve termen te beschrijven. Met name in het geval van zogenaamde vage en/of psychische klachten blijkt dat een directe relatie tussen ziekte en belastbaarheid niet gelegd kan worden (Razenberg, 1992). Volgens Razenberg maken verzekeringsartsen hier gebruik van "het niet direct meetbare begrip 'realiteit'. Dit begrip geeft de mate aan, waarin de door de belanghebbende gepresenteerde klacht voor de verzekeringsarts invoelbaar of herkenbaar invloed heeft op het functioneren" (Razenberg, 1992, 140). Slechts in gevallen waarin het probleem duidelijk is en waarin expliciete kennis aanwezig is over de samenhang tussen ziekte en belast- 
baarheid maken verzekeringsartsen gebruik van een formeel besliskundige wijże van oordelen (Razenberg, 1992, 141), Van Eck (1990) komt in zijn onderzoek naar besluitvorming bij surmenage (overspannenheid) tot een vergelijkbare conclusie. Bij psychische klachten (waar surmenage onder valt) is het 'nagenoeg onmogelijk om met behulp van objectief medische gegevens aan te tonen dat iemand niet arbeidsongeschikt is', In deze gevallen 'tracht de verzekeringsgeneeskundige de bonafiditeit van de verzekerde te bepalen, diens vertrouwen te winnen, hem bindende uitspraken te laten doen en hem te overreden of te overtuigen' (Van Eck, 1990, 208).

Volgens deze onderzoekers maakt het medisch besliskundig model van besluitvorming ${ }^{14}$ in het geval van met name vage en/of psychische klachten plaats voor een speltheoretische model, hetgeen betekent dat de beoordeling het karakter van een leer- en onderhandelingsproces krijgt. In dat proces staat de verzekeringsarts zijn beslissingsruimte voor een groot deel af aan de cliënt. In tegenstelling tot het formele model van besluitvorming is de cliënt geen passief object waarover een oordeel wordt geveld, maar speet hij of zij een actieve rol bij nemen van een besluit. Verzekeringsarts en cliënt onderhandelen over de definitie van de situatie van de cliënt, en omdat de arts niet over instrumenten beschikt die die toestand objectief weergeven, is hij of zij afhankelijk van de beschrijving die de cliënt daar zelf van geeft. Hoe die onderhandelingen tussen verzekeringsarts en cliểnt in de praktijk precies verlopen, valt echter buiten de vraagstelling van deze onderzoeken.

Razenberg en Van Eck beschouwen het onderhandelingsproces als een routinematig en onvermijdelijk aspect van de arbeidsongeschiktheidsbeoordeling. Dat het onderhandelen onvermijdelijk is, wordt verklaard door het feit dat objectief medische kennis over de relatie tussen ziekte en belastbaarheid met name in het geval van vage en/of psychische klachten ontbreekt. Onderhandelen is dus eigenlijk een verlegenheidsstrategie, waar artsen op terug vallen omdat het hen aan beter ontbreekt. Het onderzoek van Razenberg heeft als expliciete doelstelling om door middel van het inventariseren van 'praktijkkennis', 'vuistregels' te ontwikkelen en structuur te brengen in de oordeelsvorming, zodat op termijn het proces van de oordeelsvorming controleerbaar wordt voor anderen. Impliciet lijken Razenberg en Van Eck dan ook vast te houden aan het formeel rationele besluitvormingsmodel als ideaal model voor een objectieve beoordeling in het kader van de arbeidsongeschiktheidsbeoordeling. ${ }^{15}$

Ook de beleidssociologisch georiënteerde onderzoeken van Van der Veen (1990) en Mudde (1995) benadrukken het onderhandelingskarakter van de arbeidsongeschiktheidsbeoordeling. Anders dan boven genoemde onderzoeken verklaren zij het feit dat er in de beoordelingssituatie onderhandeld wordt echter niet door een gebrek aan kennis, waardoor de verzekeringsarts overgeleverd zou zijn aan de medewerking van de cliënt. Het onderhandelingskarakter van de verzekeringsgeneeskundige beoordeling is volgens hen geen verlegenheidsstrategie, maar een kenmerk van beoordelingsprocessen in het alge- 
meen. Op grond van beleidssociologische uitgangspunten betogen zij dat uitvoeringsprocessen van wet- en regelgeving niet het karakter dragen van mechanistische processen of logisch-deductieve afleidingen uit formele regels, maar dat dergelijke processen een sociaal karakter hebben. Dat betekent dat sociale regelgeving als gevolg van de interpretaties die er door betrokkenen aan gegeven worden bij de uitvoering ervan transformeert. De mate waarin regels in de praktijk ruimte laten voor interpretatie, zogenaamde discretionaire ruimte, wordt door verschillende factoren beïnvloed. Die factoren liggen op het terrein van de regelgeving zelf, de structuur van de uitvoeringsorganisatie, de aard van het werk en de relatie tussen uitvoeringsambtenaar en het publiek. In het kader van de arbeidsongeschiktheidsregelingen is de discretionaire ruimte volgens Van der Veen groot. Op de eerste plaats omdat deze wetgeving vage begrippen kent, zoals bijvoorbeeld 'arbeidsongeschiktheid'. Op de tweede plaats omdat professionals belast zijn met de uitvoering, en professionals een grote mate van autonomie toebedeeld krijgen op basis van hun expertise en omdat ze gebonden zijn aan professionele normen. Tenslotte oordelen deze professionals over complexe problematiek en hebben cliënten redelijk grote invloed op de besluitvorming omdat professionals in hoge mate afhankelijk zijn van de informatie die cliënten zelf verstrekken over hun toestand, zowel ten aanzien van hun klachten als ten aanzien van hun werkzaamheden.

Meer specifiek concludeert Van der Veen dat artsen (en arbeidsdeskundigen) in het kader van de arbeidsongeschiktheidsbeoordeling een contextuele wijze van beslissen hanteren. "De twee normen die in de wet aangereikt worden voor de beoordeling, medische beperkingen en resterende verdiencapaciteit, laten ruimte over en zijn niet voldoende restrictief om alle beslissingen te dekken" (Van der Veen, 1990, 109) "Binnen deze vrije ruimte hanteren de ambtenaren andere normen om tot een beslissing te komen: verdienste, behoefte en het professionele criterium van het zekere voor het onzekere nemen." (Van der Veen, 1990, 108).

Ook Mudde (1995) concludeert in zijn onderzoek naar de uitvoering van de ziektewet door het GAK en het Sociaal Fonds Bouwnijverheid (SFB) dat verzekeringsartsen "niet rechtlijnig en eenduidig medische kennis toepassen en uitvoering geven aan wetgeving en beleid. De besluitvorming van verzekeringsartsen is een dynamische en complexe praktijk die niet volledig herleid kan worden tot de formele structuren van de geneeskunde en de wet- en regelgeving." (Mudde, 1995, 225-226). Alhoewel Mudde in de opzet van zijn onderzoek het onderhandelingskarakter van de arbeidsongeschiktheidsbeoordeling benadrukt, ligt in zijn analyse en conclusie de nadruk op de wijze waarop verzekeringsartsen bij hun beoordeling gebruik maken van alledaagse, praktische en normatieve overwegingen. De rol van cliënten bestaat voornamelijk uit het presenteren van hun situatie aan de verzekeringsarts. In het gesprek herdefiniëren verzekeringsartsen deze situatie. "De herdefinitie van de verzuimredenen vindt niet alleen plaats in medische contexten, maar ook in sociale en normatieve contexten" (Mudde, 1995, 225). De norma- 
tiviteit van de herdefiniëring van de situatie is dan gelegen in het feit dat verzekeringsartsen oordelen vellen over de mate waarin verzekerden verantwoordelijk gedrag vertonen in hun rol als zieke of patiënt en in hun rol als werknemer. "Door middel van 'nieuwe' definities van de situatie doen artsen een beroep op het vermogen van verzekerden om 'zelf' een beslissing te nemen ten aanzien van de voortzetting of beeindiging van het verzuim." (Mudde, 1995, 225). Die normatieve noties zijn volgens Mudde géèn verlegenheidsstrategie van verzekeringsartsen, waarvan ze gebruik maken om de onzekerheid en complexiteit van de beslissingen te reduceren, maar een normaal onderdeel van deze praktijk. "Ook in situaties waarin zij hun beslissing medisch objectiveren en legitimeren, formuleren de artsen normatieve oordelen" (Mudde, 1995, 229). Die normatieve noties maken onderdeel uit van de legitimering van de besluitvorming in het licht van de sociale controle taak van verzekeringsartsen.

Ondanks de theoretische verschillen van inzet tussen de onderzoeken van Van Eck en Razenberg enerzijds en Van der Veen en Mudde anderzijds zijn de conclusies ten dele vergelijkbaar. Ook uit het onderzoek van Van der Veen en Mudde wordt duidelijk dat de cliēnt niet de passieve 'object' rol inneemt in de arbeidsongeschiktheidsbeoordeling. zoals in de formele taakstelling van artsen wordt verwacht. In de beoordeling van de arbeidsongeschiktheid is de arts afhankelijk van de wijze waarop de cliënt zijn of haar toestand presenteert. Niet alleen ziekte, maar ook andere elementen maken deel uit van die situatiebeschrijving. Wat daarbij wel en niet relevant is, is afhankelijk van de situatie van de cliënt. Ook de criteria om de toestand te beoordelen beperken zich niet tot ziekte en daaruit afleidbare arbeidsongeschiktheid, maar omvatten ook zogenaamde informele normen. Ten aanzien van het functioneren van die informele normen doen Van der Veen en Mudde wel generalistische uitspraken: die informele normen omvatten respectievelijk criteria van 'verdienste' en 'behoefte' en de professionele norm van 'het zekere voor het onzekere nemen' en het ten toon spreiden van 'verantwoordelijk gedrag' in de rol van patiënt en/of werknemer. Door deze generalisatie ten aanzien van de hantering van informele criteria lijkt de oordeelsvorming ook hier te worden voorgesteld als het nemen van besluiten, in die zin dat een fase van beschrijving van de toestand van de cliënt voorafgaat aan en gescheiden is van een fase waarin criteria worden toegepast om tot een oordeel te komen. Het onderhandelingskarakter van de oordeelsvorming lijkt vooral gelokaliseerd te worden in de eerste fase, waarin de cliënt invloed uitoefent op de beschrijving van de toestand. Het toepassen van criteria en het vellen van een oordeel blijft in handen van de arts, waarbij het trekken van een conclusie ten aanzien van de vraag of een toestandsbeschrijving aan de criteria voldoet wel een kwestie van interpreteren is. Bij die interpretatie speelt de context een rol.

Razenberg en Van Eck beschouwen het onderhandelingskarakter van de arbeidsongeschiktheidsbeoordeling weliswaar als noodzakelijk, tegelijkertijd vormt het een bedreiging voor de objectiviteit en daarmee de rechtmatigheid van arbeidsongeschiktheidsoor- 
delen. Van der Veen en Mudde betogen dat dat onderhandelingskarakter en met name de informele normen die een rol spelen bij de beoordeling, voor artsen een correctie betekenen op de ervaren onrechtvaardigheid van de consequenties van het letterlijk uitvoeren van de wet. Vanuit het perspectief van de artsen wordt de beoordeling door het hanteren van informele normen rechtvaardiger dan als ze gebaseerd zou zijn op de formele wettelijke criteria. Van der Veen wijst er op dat informele beoordelingsnormen inderdaad het sociaal selectieve karakter van de WAO corrigeren ${ }^{16}$. Tegelijkertijd betoogt hij dat het routine-matig toepassen van informele normen het gevaar in zich houdt dat maatschappelijke vooroordelen kunnen doorwerken in de beoordeling, hetgeen ten nadele kan werken van bepaalde groepen, zoals vrouwen en buitenlanders.

Alhoewel de besproken onderzoeken naar de verzekeringsgeneeskundige praktijk sterk van inzet verschillen, delen ze de conclusie dat het praktisch handelen afwijkt van het formeel rationeel model van besluitvorming, dat gebaseerd is op medische kennis. Alleen Timmer wijt dat aan een gebrek aan medische kennis. In de andere onderzoeken komt naar voren dat besluiten die in de verzekeringsgeneeskundige praktijk genomen worden geen formeel, maar een contextueel karakter hebben. Stone concentreert zich in haar analyse met name op de vraag waarom het arbeidsongeschiktheidscriterium geen basis kan bieden voor restrictieve besluitvorming. Van Eck en Razenberg concentreren zich op de vraag welke andere elementen een rol spelen in de beoordeling. $\mathrm{Zij}$ constateren dat de cliěnt grote invloed heeft op de besluitvorming, omdat op basis van medische kennis (voor sommige klachten) geen objectieve beschrijving van de toestand van de cliënt mogelijk is. Om die toestand in kaart te brengen is de arts afhankelijk van de (subjectieve) informatie van de cliënt zelf. Mudde en Van der Veen laten zien hoe de betekenis van regels onder invloed van de praktische handelingscontext transformeren. Ook hier blijkt dat cliënten invloed hebben op de besluitvorming, maar niet alleen cliënten, ook normen en waarden van verzekeringsartsen zelf dragen bij aan die transformatie.

\section{Logica's van praktijken}

Van der Veen en Mudde betogen in hun werk dat het praktisch handelen van verzekeringsartsen niet opgevat kan worden als een afgeleide van formele kennis of regels. Het praktisch handelen kent haar eigen contextgebonden logica. Van der Veen en Mudde laten in hun analyses zien hoe in het praktische handelen van verzekeringsartsen regels in het licht van de context waarbinnen zij besluiten nemen geïnterpreteerd worden. Zowel Van der Veen als Mudde beschrijven het praktisch handelen als een praktijk waarin besluiten worden genomen. En alhoewel zowel het inventariseren van de situatie van de cliënt als het toepassen van criteria een kwestie is van het interpreteren van gegevens en regels in het licht van de context, blijft het nemen van een besluit een 
cognitieve gebeurtenis die op een aanwijsbaar moment plaats vindt. De activiteit waar het in de praktijk om gaat is er een van beslissingen nemen en in die zin ligt hun analyse dicht aan tegen het standaardbeeld over die praktijk.

In het wetenschapsonderzoek en de ethnomethodologie is deze conceptualisering van besluitvormingsprocessen bekritiseerd. Berg (1997) betoogt in zijn onderzock naar het functioneren van beslissingsondersteunende technieken in de geneeskunde dat een 'beslissing' vaak een achteraf constructie is waarin rationaliteit aan gebeurtenissen wordt toegeschreven. '...as is the case with medical criteria then the occurence of a decision is often constructed post hoc to underseore the rationality of events' (Berg, 1997, 137). In het praktisch handelen zelf is vaak helemaal geen sprake van het nemen van beslissingen, in de zin van 'een weloverwogen besluit nemen' (Berg, 1992). Situaties spreken voor zich en artsen doen dingen routinematig. 'Beslissingen' komen incrementeel tot stand, ze vormen het resultaat van stapsgewijze reacties op een steeds veranderende situatie, dat achteraf wordt benoemd/gereconstrueerd als een rationele reactie op een achteraf gedefinieerd patiënt-probleem. De complexiteit en diversiteit van te beheersen heterogene elementen in het traject vragen om een voortdurende aanpassing aan en reactie op contingenties die zich voordoen. Gedurende het behandeltraject is het probleem in samenhang met de oplossingsstrategie ën getransformeerd van een probleem waarmee de patiēnt de spreekkamer binnen kwam tot een behandelbaar probleem. Het resulterende traject is geen product van bewust ontwikkelde plannen, noch is het het resultaat van een serie van beslissingen. 'The course the trajectory takes, then is an "incourse-accomplishment", which is attributed to "decisions" only in retrospect' (Berg, 1997, 138).

Het proces waarin interactiepartners in de praktijk door een reeks van handelingen tot een bepaald resultaat komen, duid ik aan met de term 'logica'. De term logica ontleen ik aan Mol (Mol, 1993; Mol en Berg, 1994). Mol geeft aan dat de term logica zowel de conceptuele als de praktische behandeling van een object omvat ${ }^{17}$. De term logica doelt op de vraag hoe heterogene elementen in de praktijk coherent gemaakt worden, als een coherent geheel gaan functioneren. Het is deze logica van de verzekeringsgeneeskundige praktijk die in dit onderzoek centraal staat. De term logica verdient de voorkeur boven besluitvorming omdat aan de term besluitvorming te veel een connotatie kleeft van bewust en expliciet keuzes maken ${ }^{18}$. Het besluit dat uiteindelijk genomen wordt en de factoren die daarin een rol spelen staan in dit onderzoek op de tweede plaats. De aandacht is daarentegen gericht op het werk dat verzet wordt om tot een resultaat te komen. Daarbij gaat het niet zozeer om factoren die worden meegewogen, maar over de wijze waarop fenomenen waar het in de praktijk om gaat door betrokkenen worden benoemd, welke oplossingsstrategiee' n die 'probleemdefiniëring' impliceert, welke handelingsopties voor betrokkenen vanzelfsprekend zijn en welke uitgesloten zijn. Het staat hier niet ter discussie dat informele 'normen' gehanteerd worden, waar het om gaat is de vraag 
waarom bepaalde kwesties op een specifiek moment een rol spelen (en andere niet) in de praktische ordening van het verzekeringsgeneeskundige handelen en waarom het binnen de context legitiem en vanzelfsprekend is dat ze worden gehanteerd.

Mol richt zich in haar analyses veelal op de verschillende betekenissen die fenomenen in verschillende praktijken krijgen. Zo laat ze in haar onderzoek naar bloedarmoede (zie bv. Mol en Berg, 1994) zien dat anemie zowel statistisch als klinisch gedefinieerd wordt. Klinische en statistische definities vallen niet samen, en iemand kan volgens de statistische criteria bloedarmoede hebben, maar volgens de klinische niet. Op het eerste gezicht lijkt dat onlogisch en verwarrend, maar in de praktijk van de spreekkamer transformeren deze verschillende soorten kennis tot een logisch geheel. Ingebed in de praktijk en verbonden met andere zaken ontstaat een nieuwe orde, die niet samenvalt met de statistische, noch met de klinische. Om de logica van een praktijk te begrijpen is het niet voldoende om de kennissystemen van de klinische epidemiologie te doorgronden. Het gebruik van de klinische epidemiologie als maatstaf om de rationaliteit van de praktijk aan af te meten '..helpt ons niet om de eigen logica van de complexe en ogenschijnlijk rommelige praktijk te begrijpen. Daar is onderzoek voor nodig dat in die praktijk kruipt en de soms grillige bochten ervan in kaart brengt" (Mol, 1993, 13). Vertaald naar de verzekeringsgeneeskundige praktijk levert dit bijvoorbeeld de vraag op hoe arbeidsongeschiktheidsoordelen geproduceerd worden en wat arbeidsongeschiktheid 'is' of hoe arbeidsongeschiktheid 'gemaakt' wordt in die praktijk. Deze vraag vormt een belangrijk onderdeel van deze studie. Wat arbeidsongeschiktheid is, is, ondanks allerlei definities, niet op voorhand duidelijk, maar wordt geconstrueerd door de wijze waarop ziekte, klachten, problemen, etc. in de praktijk worden 'behandeld'.

Bij de constructie en productie van 'fenomenen' in het handelen speelt taal een belangrijke rol. In de taal worden zaken op specifieke wijze benoemd, en die benoeming is niet neutraal. Met het benoemen van verschijnselen heeft de taal een ordenende kracht ".. om de manier waarom zij verschijnselen wel en niet ter sprake brengt, wel en niet waarneembaar maakt, wel en niet op elkaar betrekt" (Mol en Van Lieshout, 1989, 147). Ten dele geĩnspireerd door het werk van Foucault, laten $\mathrm{Mol}$ en Van Lieshout in hun analyses van de medische taal in de huisartsgeneeskunde en de geestelijke gezondheidszorg zien dat het er toe doet hoe verschijnselen benoemd worden. Het spreken over ziektes heeft andere consequenties dan de dingen waar patiënten mee komen benoemen als noden of problemen. In de term nood gevat, zo laten zij zien, "...is de ellende iets waar mensen zich mee dienen te verzoenen omdat het inherent is aan het menselijk bestaan" (blz. 150). Als huisartsen in de jaren ' 50 de ellende van mensen vatten in de term nood, zien zij hun taak dan ook als het zoeken naar wegen om die verzoening tot stand te brengen. Het spreken over problemen, zoals dat in de jaren '60 meer gangbaar wordt, vraagt daarentegen om oplossingen. Huisartsen zien het dan ook als hun taak mensen te ondersteunen in het zoeken van die oplossingen. Met het op specifieke wijzen benoemen 
van de moeilijkheden, veranderen ideeên over wat er gedaan moet worden en verschuift de taak en de handelingswijze van de huisarts.

Alhoewel Mol in haar publicaties aangeeft dat het om praktijken te begrijpen nodig is in die praktijk te kruipen, beperkt zij zich in haar analyses over het algemeen tot de talige weerslag van die praktijk in leerboeken en tijdschriften en interviewmateriaal van deelnemers aan de praktijk. Dat (en hoe) de taal de handelingswijze van bijvoorbeeld huisartsen in de praktijk ordent, valt buiten het bestek van haar onderzoek. In het werk van ethnomethodologen is wel expliciet aandacht voor het praktisch handelen (Livingstone, 1987; Silverman, 1993; Denzin and Lincoln, 1994). Ook zij houden zich bezig met de ordening van het praktisch handelen. Oorspronkelijk richtte de ethnomethodologie zich op alledaagse activiteiten. De centrale vraag daarbij was hoe mensen alledaagse activiteiten produceren en organiseren. In toenemende mate is de aandacht van de ethnomethodologie verschoven naar institutionele activiteiten. In dergelijk onderzoek staat de vraag centraal hoe deze activiteiten georganiseerd zijn en hoe die organisatie onderdeel is van de activiteiten zelf. Institutionele of context elementen spelen daarbij een rol, maar vormen geen kader waarbinnen die activiteiten plaatsvinden. De institutionele context wordt in de activiteit gereproduceerd en ondergaat in dat reproductieproces een verandering.

Daarbij gaat men er van uit dat de ordening of structurering een eigenschap is van het handelen, die niet herleid kan worden tot "psychological or other characteristics of particular speakers" (Heritage J geciteerd in Silverman, 1993, 125). Die ordening ontstaat in het handelen zelf, en is niet vooraf gegeven door intenties die betrokken actoren hebben. Dat betekent niet dat de perspectieven of verklaringen van de discussie-partners irrelevant zijn, wel dat ze door de onderzoeker niet klakkeloos over genomen kunnen worden. Deze verklaringen maken daarentegen deel uit van het onderzoeks-object en maken onderdeel uit van het constructie- of productieproces zelf.

In het ordenen van praktisch handelen wordt 'realiteit' geproduceerd. Dat betekent dat 'fenomenen' zoals bijvoorbeeld arbeidsongeschiktheid in het praktisch handelen geconstrueerd worden. Maar ook de subjecten behoren tot die 'realiteit', Dus ook de betrokkenen bij de arbeidsongeschiktheidsbeoordeling zoals de cliënt, de verzekeringsarts, de huisarts en de werkgever worden geconstrueerd. Dat wil zeggen: tijdens de interactie wordt duidelijk wat het betekent om een cliënt, een verzekeringsarts of een werkgever te zijn. "Individuals are not pre-defined entities with particular psychological properties but are 'subjects', constituted in specific institutional and discursive practices' (Silverman, 1989, 134). De identiteit van betrokkenen wordt gedurende de interactie (het handelen) geconstrueerd. Ook bij die constructie speelt volgens Silverman het vocabulaire dat gehanteerd wordt een belangrijke rol $^{19}$. Silverman laat in zijn analyses van gesprekken tussen artsen en (ouders van) patiēnten zien dat het uitmaakt of in gesprekken een medisch-technisch vocabulaire gehanteerd wordt of een sociaal. De 'toestand' van patiënten 
wordt afhankelijk van het vocabulaire anders benoemd en de criteria op grond waarvan besloten wordt tot wel of niet ingrijpen veranderen daarmee. Waar in een medisch-technisch vocabulaire anatomische afwijkingen vragen om operatief ingrijpen, kan bij het hanteren van een sociaal vocabulaire het belang van een dergelijke afwijking naar de achtergrond verschuiven als iemand sociaal goed functioneert. Op grond van dat sociaal goed kunnen functioneren, verdwijnt de oplossing van operatief ingrijpen uit het vizier. In deze verschillende beoordelingssystemen is echter niet alleen de uitkomst verschillend, ook de identiteit van betrokkenen verschilt. Binnen een medisch-technisch vocabulaire is de patiënt bijvoorbeeld, een object, over wiens anatomische toestand door anderen een oordeel wordt uitgesproken. Binnen een sociaal vocabulaire wordt de patiënt een subject en wordt gesproken over diens sociale welbevinden, waarbij de patiënt zelf een stem heeft in dat gesprek.

Om de vraag naar de ordening of de logica van de verzekeringsgeneeskundige praktijk te onderzoeken zal ik gebruik maken van ideeën uit het wetenschapsonderzoek en de ethnomethodologie. Het uitgangspunt daarbij is dat die praktische ordening niet te herleiden is tot theoretische principes, maar tot stand komt in het praktische handelen zelf. De wijze waarop zaken benoemd worden, en de wijze waarop de taal ingebed is in dat handelen, speelt daarbij een belangrijke rol. Daarbij gaat het niet alleen om de woorden, maar ook en vooral om de structuur van de gesprekken. In het benoemen van zaken en structuur van gesprekken worden handelingsopties voor betrokken actoren geconstrueerd, zowel binnen het gesprek als daarbuiten. Die structuur en handelingsopties constitueren en veronderstellen bepaalde subjecten. In die ordening van het handelen, of de logica van het handelen, wordt realiteit, dat wil zeggen worden fenomenen en subjecten geconstrueerd. Met andere woorden in de ordening of logica van het handelen krijgt 'arbeidsongeschiktheid' betekenis maar krijgen ook de concepten 'verzekeringsarts' en 'cliënt' een specifieke invulling. Die ordening ontstaat tijdens de interactie en omvat zowel datgene wat zich binnen de spreekkamer bevindt als delen van de wereld daarbuiten. Met andere woorden: werk, ziekte, maar ook behandelend artsen en werkgevers krijgen een plaats en betekenis in de structuur van de interactie. Dat wil niet zeggen dat de wereld er buiten de spreekkamer ook daadwerkelijk zo uit ziet, maar binnen de spreekkamer worden die elementen in onderlinge relatie geconstrueerd en daarmee geordend. Die ordening heeft consequenties in de zin dat ze sommige handelingen meer vanzelfsprekend en andere minder goed mogelijk maakt. Binnen dat praktische handelen wordt de institutionele context van de praktijk gereproduceerd en getransformeerd. Het wettelijk kader, de formele verhouding tussen betrokken actoren en hun bevoegd- en verantwoordelijkheidsverdeling vormen niet zozeer een gegeven kader waarbinnen mensen handelen, maar krijgen in dat handelen een specifieke plaats en betekenis. In dit onderzoek wordt die formele inbedding dan ook tijdelijk tussen haakjes gezet, om na te gaan waar en hoe ze in het praktisch handelen een rol speelt. 
In het volgende hoofdstuk zal ik eerst de locatie van dit onderzoek naar verzekeringsgeneeskundige praktijk uiteenzetten, om vervolgens een verdere operationalisering van de term logica in en de methodologische opzet van dit onderzock uiteen te zetten. In hoofdstuk 3 tot en met 5 volgt dan de analyse van het materiaal. De opzet en thema's van die hoofdstukken zal ik uiteenzetten in hoofdstuk 2 . In hoofdstuk 6 worden conclusies getrokken ten aanzien van de logica van de verzekeringsgeneeskundige praktijk en aan de consequenties die hieraan verbonden moeten worden.

\section{Noten}

1. Ten tijde van het onderzoek werden deze artsen aangeduid met de term verzekeringsgeneeskundigen; inmiddels is de term verzekeringsartsen meer gangbaar. Ik zal dan ook de term verzekeringsartsen gebruiken.

2. Ongeveer een kwart van de artsen in Nederland werkt in de niet-curatieve sector. Het werk dat deze artsen verrichten loopt zeer uiteen. Deze artsen zijn behalve als verzekeringsarts bijvoorbeeld werkzaam als onderzoeker, bedrijfsarts, consultatie-bureau arts, jeugdarts, adviserend geneeskundige, afdelingsmanager, directeur, docent, verslavingsarts, inspecteur of keuringsarts (Van den Berg en Kerkhof, 1994). Ongeveer een vijfde van deze niet-curatief werkzame artsen is werkzaam in de verzekeringsgeneeskunde (Rapportage arbeidsmarkt zorgsector, 1997).

3. Een belangrijk deel van de verzekeringsartsen is werkzaam in het kader van de Ziektewet en WAO. Daarnaast omvat deze groep echter ook artsen die werkzaam zijn als medisch adviseur voor particuliere verzekeringen en het ziekenfonds. Alhoewel deze laatste functies ook wel aangeduid worden als medisch adviseur of adviserend geneeskundige.

4. In 1995 is ruim 30 miljard aan uitkeringen in het kader van de ZW en de AAW/WAO uitgekeerd (SCP, Sociaal en cultureel rapport 1996).

5. Begin jaren '90 zijn er in Nederland een zestal proefschriften verschenen die het verzekeringsgeneeskundig handelen tot onderwerp hebben. Drie daarvan zijn uitgevoerd door onderzoekers gelieerd aan het GAK (Van Eck, 1990) of de GMD (Croon en Langius, 1993; Razenberg. 1992) en richten zich op verzekeringsartsen bij de uitvoering van respectievelijk de Ziektewet en de WAO. De beschrijving van het verzekeringsgeneeskundig beoordelingsproces die deze onderzoekers geven, staat ten dienste van pogingen om de kwaliteit daarvan te verbeteren. Twee studies zijn van beleidssociologische signatuur, waarvan één geheel aan de uitvoering van de Ziektewet is gewijd (Mudde, 1995) en én de uitvoeringsprocessen van een aantal verschillende wetten analyseent, waaronder de WAO (Van der Veen, 1990). Kaiser (1992) tenslotte heeft een vergelijkend onderzoek verricht naar het functioneren van verzekeringsartsen enerzijds en bedrijfsartsen met verzekeringsgeneeskundige taken anderzijds.

6. Voorbeelden van artikelen waarin verzekeringsartsen begin jaren ' 90 in de publieke media onder vuur werden genomen zijn 'De falende poortwachters van de WAO' van Willem Velema in Intermediair (1991) en 'Explosie WAO: "zo ontstond een klimaat van ga je gang maar" ' van Kees Calje in NRC-handelsblad (1993) 
7. Zie bijvoorbeeld voor het wetenschapsonderzoek Collins, 1985; Latour, 1987, 1988; Mol, 1993 en Mol en Berg, 1994; voor de ethnomethodologie Garfinkel, 1967; Lynch, 1985; Livingstone, 1987; Denzin and Lincoln, 1994.

8. In haar boek 'The disabled state' geeft Deborah Stone een interessante, historisch-politicologische analyse van het ontstaan en de ontwikkeling van arbeidsongeschiktheidsregelingen in Duitsland, Engeland en de Verenigde Staten. Daarbij gaat ze uitvoerig in op de rol van medische kennis binnen deze stelsels en de rol van artsen bij de redistributie van inkomens en de politieke implicaties daarvan.

9. Klasien Horstman (1996) laat in haar studie 'Verzekerd Leven; artsen en verzekeringsmaatschappijen 1880-1920' naar de ontwikkeling van de poortwachtersfunctie van artsen bij levensverzekeringen eveneens zien dat de betrokkenheid van artsen aanvankelijk gemotiveerd werd door het grote vertrouwen dat levensverzekeringsmaatschappijen (en het publiek) stelden in artsen. Artsen zouden met behulp van hun medische technieken in staat zijn om goede en slechte risico's van elkaar te scheiden.

10. Die expertise is niet alleen gebaseerd op technische hulpmiddelen, maar tevens op kennis.

11. Zie bijvoorbeeld parlementaire enquête uitvoering sociale zekerheid blz 42 "De bedrijfsverenigingen stellen eenduidigheid van de uitvoering voorop. Gelijke gevallen moeten gelijk behandeld worden"; blz. 43 "Belangrijk voor een rechtmatige uitvoering is dat gelijke gevallen gelijk worden behandeld en tevens recht wordt gedaan aan verschillen tussen uitkeringsgerechtigden. Dit vormt de voornaamste reden om de wetgeving, waar deze ruimte laat voor interpretatieverschillen, aan te vullen met eenduidige uitvoeringsinstructies". blz. 82 "Ingevolge vaste jurisprudentie van de Centrale Raad voor beroep dient onder <<ongeschiktheid tot werken $>$ te worden verstaan het op medische gronden naar objectieve maatstaven gemeten niet kunnen werken of mogen verrichten van de in aanmerking komende arbeia".

Zie ook Croon en langius (1993) blz 5 "de uitvoeringsorganen, de wetgever en de beroepsrechter leggen bijvoorbeeld de nadruk op objectiviteit met het oog op een uniforme gevalsbehandeling. Een maatschappelijke waarde die hieraan ten grondslag ligt is rechtsgelijkheid, het principe van gelijke behandeling van gelijke gevallen".

Van Eck (1990) blz 35 "Hij [de verzekeringsarts] moet daarom [gezien zijn controle-functie en het niet zonder meer kunnen uitgaan van vertrouwen, AM] relatief meer aandacht besteden aan de objectivering van de klachten van de verzekerde dan een behandelend arts. Ook de beroepsrechter stelt voor de vaststelling van de arbeidsongeschiktheid in de zin van de Ziektewet de eis dat verzekerde op medische gronden, naar objectieve maatstaven gemeten, niet kan of mag verrichten."

12. Naast het ontwikkelen van een verzekeringsgeneeskundig referentiekader dat een objectieve verzekeringsgeneeskundige oordeelsvorming zou moeten kunnen garanderen zijn er ook andere initiatieven geweest om verzekeringsgeneeskundige kennis te ontwikkelen. Daartoe behoren initiatieven voor intercollegiale toetsing, waarbinnen normen ontwikkeld zouden moeten worden om de gevalsbehandeling te uniformeren en initiatieven tot protocol-ontwikkeling (zie bijvoorbeeld Smits 1988; Croon, 1988; Steen, 1988).

13. Deze benadering van de verzekeringsgeneeskundige oordeelsvorming wordt in de opleiding voor verzekeringsartsen gedoceerd en in de praktijk wisselende mate gebruikt. In het volgende hoofdstuk kom ik op deze benadering terug. 
14. Het medisch besliskundig besluitvormingsmodel waar deze onderzoekers naar verwijzen is een formeel rationeel besluitvormingsproces, waarin een besluit te herleiden valt tot expliciet geformuleerde beslisregels.

15. Die impliciete aanname ligt besloten in de doelstelling van het onderzoek. De vraagstelling van deze studies richt zich op het onderzoeken van de mogelijkheid om het verzekeringsgeneeskundig handelen te beschrijven in formele beslisregels. Het nut van een dergelijke exercitie valt alleen te begrijpen vanuit de gedachte dat, als het mogelijk is om beslissingen in formele beslisregels te beschrijven, de verzekeringsgeneeskundige praktijk via formalisering te verbeteren zou zijn.

16. Met sociaal selectieve karakter van wetgeving doelt Van der Veen op het mechanisme dat ogenschijnlijk neutrale, dat wil zeggen voor iedereen gelijke, regelingen in de praktijk verschillend uitpakken voor verschillende groepen. Bij de WAO creeert het feit dat het verlies aan inkomen bepalend is voor de mate van arbeidsongeschiktheid bijvoorbeeld sociale selectiviteit. Naar mate het inkomen lager is, is de kans groter dat er een functie te duiden is, waarmee hetzelfde inkomen verdiend kan worden. Daarmee wordt de kans op cen uitkering aanzienlijk kleiner.

17. De term logica heeft dan ook verwantschap met de term discours van Foucault. Mol kiest echter voor de term logica's omdat het discours-begrip van Foucault gereserveerd wordt door grote denk-en handelingsstijlen. Foucault beschouwt de geneeskunde vanaf begin negentiende eeuw tot heden als eén discours. terwijl Mol juist ingaat op de specifieke redeneer- en handelingsstijlen die binnen de hedendaagse geneeskunde, zelfs binnen de verschillende disciplines, al naar gelang plaats en tijd, van elkaar verschillen.

18. In navolging van Mudde en Van der Veen zal ik de verzekeringsgeneeskundige praktijk dus niet opvatten als een afgeleide van formele kennis of regelsystemen, maar haar beschouwen als een praktijk met een eigenstandige logica. In tegenstelling tot deze beleidssociologische studies zal ik die echter niet bij voorbaat benaderen als een praktijk waar besluiten worden genomen, om vervolgens vast te stellen welke normen, formeel of informeel een rol spelen. Daarentegen zal ik de logica van die praktijk beschouwen als een handelingspraktijk waarin heterogene elementen tot een logisch geheel worden getransformeerd. De centrale vraag daarbij is de wijze waarop activiteiten en werkelijkheden geproduceerd of georganiseerd worden in het praktisch handelen.

19. Silverman maakt, zoals veel ethnomethodologen, in zijn werk gebruik van conversatic-analyse om de rol van taal in ordeningsprocessen te analyseren. In tegenstelling tot anderen beperkt hij zich echter niet tot analyse van gesprekken, maar concentreert hij zich expliciet op de samenhang tussen gesprekssequenties en de context van de specifieke institutionele situatie, zonder dat hij de ordening van die gesprekken herleidt tot een product van die situatic. 



\section{Verzekeringsartsen en de Ziektewet}

\section{Inleiding}

De doelstelling van dit onderzoek is om inzicht te verschaffen in de logica van de verzekeringsgeneeskundige praktijk. Die inzet heeft op de eerste plaats een theoretische component. Die theoretische component bestaat uit de vraag hoe in de dagelijkse praktijk 'besluiten' over arbeidsongeschiktheid worden genomen worden. Op basis van ethnomethodologisch en wetenschapsonderzoek heb ik beargumenteerd dat de conceptualisering van deze processen, die leiden tot het al dan niet toelaten van mensen tot de arbeidsongeschiktheidsregelingen, als formeel-rationele besluitvormingsprocessen op bezwaren stuit. Dat wil niet zeggen dat regels en kennis geen enkele rol spelen in de dagelijkse beoordelings- en begeleidingspraktijk, wel dat het formele systeem van regels en kennis geen blauwdruk vormt voor of afspiegeling is van de dagelijkse handelingspraktijk. Het beoordelen van de dagelijkse praktijk op basis van de principes (of formele systemen) miskent de eigen rationaliteit van de dagelijkse praktijk. Die rationaliteit van de dagelijkse praktijk heeft niet zozeer een formeel karakter als wel een eigen ratio, of logica. Die logica komt tot stand in interacties en onderhandelingen in de dagelijkse praktijk.

Dit onderzoek wil inzicht bieden in die logica en stelt zich de vraag hoe die interacties en onderhandelingen in de dagelijkse praktijk gestructureerd zijn, welke patronen daarin te herkennen zijn en welke consequenties ze hebben. Die consequenties hebben dan betrekking op de vraag hoe fenomenen zoals arbeidsongeschiktheid geconstrueerd worden en hoe subjecten geconstitueerd worden. Alhoewel die constructie en constitutie in de dagelijkse interactie tot stand komen, en daarmee tot een bepaalde hoogte contingent zijn, zijn ze niet willekeurig. Dat heeft te maken met het feit dat interactiepartners niet volstrekt geïsoleerd opereren, maar deel uitmaken van een grotere 'samenleving', en in hun interactie voortdurend een beroep doen op vanzelfsprekendheden die gelden in die bredere samenleving. Meer concreet betekent dat, dat de interactiepartners als vanzelfsprekend gebruik maken van een aantal normen die gelden in onze samenleving, en die normen tegelijkertijd transformeren.

De meer theoretische georiênteerde vraagstelling van dit onderzoek is dus gericht op het verschaffen van inzicht in 'mechanismen' die een rol spelen bij het constitueren van een 'logica' in het praktisch handelen. Die theoretische vraagstelling gaat gepaard met een meer empirische, namelijk met de vraag hoe de logica van de verzekeringsgeneeskundige praktijk er uit ziet. De verzekeringsgeneeskundige praktijk is echter dusdanig groot en divers dat hier om praktische redenen een afbakening moet plaats vinden. In dit 
onderzoek is gekozen voor de verzekeringsgeneeskundige praktijk rondom de uitvoering van de Ziektewet, zoals die werd uitgevoerd binnen de Bedrijfsvereniging voor de Gezondheid, Geestelijke en Maatschappelijke belangen (BVG).

De keuze voor een specifieke locatie is noodzakelijk in het licht van de uitvoerbaarheid van het onderzoek en het stelt tevens beperkingen aan de mate waarin de uitkomsten van dit onderzoek generaliseerbaar zijn naar andere praktijken. Het onderzoek verschaft inzicht in de specifieke 'logica' van deze lokale praktijk. Toch beperkt het onderzoek zich niet tot deze ene praktijk alleen omdat het niet zozeer gericht is op het in kaart brengen van de relatie tussen plaatsgebonden factoren en de specifieke besluiten. Het onderzoek richt zich op het lokale overstijgende mechanismen die in de lokale onderhandelingssituatie door werken'. Alhoewel ook deze mechanismen context-gebonden zijn, makt het speerpunt van de analyse het wel mogelijk om te reflecteren op aannames die ten grondslag liggen aan andere verzekeringsgeneeskundige praktijken, rondom de uitvoering van de Ziektewet en wellicht ook die rondom de uitvoering van de WAO. In de conclusie van dit boek zal ik hier op terug komen.

Gedurende het onderzoek hebben zich een aantal wijzigingen voltrokken in de uitvoering van de Ziektewet bij de voormalige Bedrijfsvereniging voor de Gezondheid, Geestelijke en Maatschappelijk Belangen $(B V G)^{2}$. Waar de uitvoering van de Ziektewet in het verleden was opgedragen aan de Bedrijfsverenigingen, is de betaling krachtens deze wet voor een groot deel van de werknemers buiten werking gesteld, en is de verantwoordelijkheid voor de arbeidsongeschiktheidsbeoordeling en -begeleiding overgedragen aan werkgevers. De werkgevers dienen daartoe een gecertificeerde deskundige dienst (een Arbo-dienst) in te schakelen. Deze Arbo-diensten voeren naast de verzuimcontrole en begeleiding ook taken op het terrein van de bedrijfsgezondheidszorg uit. Deze wetswijzigingen hebben een aantal structurele wijzigingen in de organisatie van de arbeidsongeschiktheidsbeoordeling en begeleiding te weeg gebracht. De huidige positie van artsen in het veld vertoont desalniettemin overeenkomsten met de situatie van voor de wetswijziging. Zowel voor als na de wetswijzigingen opereren zij in een afhankelijkheidsrelatie met zieke werknemers, werkgevers en de uitvoeringsorganisatie (resp. de Bedrijfsvereniging en de Arbo-dienst), zij het dat er in die afhankelijkheidsrelaties wel enige verschuivingen zijn opgetreden, omdat de Arbo-dienst, anders dan de Bedrijfsvereniging in opdracht van de werkgever optreedt. En ook de processen van verzuimcontrole en begeleiding van voor en na de wetswijzigingen vergelijkbaar, in de zin dat werknemers die zich hebben ziek gemeld voor controle (en begeleiding) een bezoek brengen aan de arts en de arts toetst of de claim van de zieke werknemer dat hij of zij niet kan werken plausibel is. Daar dit onderzoek zich richt op met name dat laatste proces zijn de onderzoeksresultaten nog steeds van belang.

Naast empirische argumenten zijn er echter ook theoretische argumenten aan te voeren om de stelling dat het onderzoek, ondanks de wetswijzigingen die de afgelopen jaren zijn 
doorgevoerd met betrekking tot ziekteverzuimcontrole en begeleiding, niet aan belang heeft ingeboet. Op basis van de theoretische uitgangspunten kan betoogd worden dat wetswijzigingen niet per definitie veranderingen in de praktijk te weeg brengen. Die eén op één relatie tussen regels en praktijk is immers geproblematiseerd. Het onderzoek verschaft ten dele inzicht in de wijze waarop regels en praktijk wel met elkaar samenhangen omdat gedurende het onderzoek een aantal wijzigingen in wet- en regelgeving zijn doorgevoerd. Bovendien zal het onderzoek, omdat het inzicht versehaft in het type processen en mechanismen dat werkzaam is in de praktijk, handvatten bieden om een verwachting uit te spreken over de wijze waarop nieuwe wetswijzigingen de praktijk zullen beïnvloeden. In de conclusies van het boek zal ik dan ook ingaan op de vraag of deze wijzigingen van wet- en regelgeving zich verhouden tot de 'bestaande' logica van de praktijk.

In dit hoofdstuk zal ik de locatie en de opzet van het onderzoek nader uiteenzetten. De verandering van de formele structuur van de begeleiding en controle van zieke werknemers is inmiddels volledig doorgevoerd. Het onderzoek heeft echter plaatsgevonden gedurende de overgangsperiode tussen de werking van de Ziektewet en de huidige situatie. In de eerste paragraaf zal ik kort de formele regelgeving met betrekking tot de Ziektewet beschrijven, zoals die gold gedurende de periode van het onderzoek. Om de overgangssituatie enigszins begrijpelijk te maken zal ik waar nodig tevens ingaan op de oude en de huidige situatie. Vervolgens zal ik ingaan op de dagelijkse gang van zaken rondom verzuimcontrole en begeleiding bij de BVG, in het bijzonder op de rol van artsen daarbinnen. Ondanks alle wetswijzigingen in het veld was gedurende de periode van dataverzameling voor dit onderzoek in die dagelijkse gang van zaken (nog) nauwelijks iets veranderd. In de laatste paragraaf zal ik op basis van de schets van de locatie waar het onderzoek heeft plaatsgevonden de verdere opzet van deze studie beschrijven.

\section{Wetgeving en uitvoeringsorganisaties}

De verzekeringsgeneeskundige praktijk die in dit boek centraal staat draait om de uitvoering van de Ziektewet. De Ziektewet was een wet die een verzekering tegen loonderving regelde. Alle werknemers, met uitzondering van ambtenaren', konden in Nederland een beroep doen op de Ziektewet als zij niet in staat waren om hun werkzaamheden uit te voeren vanwege ziekte of gebrek. De Ziektewet compenseerde het verlies aan inkomen dat daardoor ontstond.

De Ziektewet is na jarenlange politieke discussies uiteindelijk ingevoerd in 1930. Alhoewel de globale doelstelling, het verzorgen van een verzekering tegen loonderving ten gevolge van ziekte of gebrek, nog steeds overeind staat, is de Ziektewet tussen 1930 en heden een aantal keren ingrijpend veranderd. In 1939 is bijvoorbeeld de uitkerings- 
duur verlengd van 26 naar 52 weken. In 1967 is het aantal verzekerden sterk uitgebreid en werd, door het afschaffen van de Ongevallenwet en de Invaliditeitswet, verzuim ten gevolge van bedrijfsongevallen ook onder de Ziektewet gerangschikt. In 1994 is er een wachttijd van 6 weken ingevoerd voor de uitbetaling van ziekengeld. Tijdens deze wachttijd heeft de werkgever een loondoorbetalingsverplichting.

Samen met de WAO en de AAW vormde de ZW de verzekering tegen loonderving in het geval van arbeidsongeschiktheid wegens ziekte of gebrek ${ }^{4}$. De Ziektewet verzekerde tegen loonderving gedurende de eerste 52 weken van het verzuim. Daarbij ging het om het verlies aan inkomen dat veroorzaakt werd doordat een werknemer zijn of haar eigen werkzaamheden niet meer kon uitvoeren wegens ziekte of gebrek. De AAW en de WAO traden in werking na die periode en kenden dus een wachttijd van één jaar. Bovendien verschilde het arbeidsongeschiktheidscriterium van dat van de Ziektewet, in de zin dat het betrekking had op alle gangbare, dat wil zeggen algemeen geaccepteerde arbeid ${ }^{5}$ en niet alleen op de werkzaamheden die een werknemer op het moment van de ziekmelding verricht. De bepaling van de hoogte van de uitkering was gebaseerd op de theoretische mogelijkheid of iemand in staat was om inkomsten uit arbeid te verkrijgen die gelijk stonden aan zijn oude inkomen, daarbij aangetekend dat voor de hoogte van de uitkering een maximum was vastgelegd. Afhankelijk van het inkomensverlies werd een gehele of een gedeeltelijke arbeidsongeschiktheidsuitkering vastgesteld. Deze aspecten van de WAO zijn tot op heden niet gewijzigd.

Tussen begin 1994 en nu is Ziektewet en de uitvoering daarvan, of beter gezegd de controle en begeleiding van werknemers gedurende de eerste 52 weken van de ziekte, drastisch veranderd. Voor 1994 was de uitvoering van de Ziektewet middels de Organisatiewet Sociale Verzekering (OSV), opgedragen aan de Bedrijfsverenigingen (Veerman, 1990). Bedrijfsverenigingen waren bedrijfstakgewijze organisaties van werkgevers en werknemers. De Bedrijfsverenigingen waren verantwoordelijk voor de premie-inning, de controle en de uitkering van het ziekengeld. In Nederland waren in 1995 achttien bedrijfsverenigingen, waarvan dertien hun administratie lieten verzorgen door het GAK, het Gemeenschappelijk Administratie Kantoor. De BVG was één van de zogenaamde zelfadministrerende bedrijfsverenigingen, die de uitvoering in eigen beheer hielden ${ }^{6}$.

Binnen de zelfadministrerende bedrijfsverenigingen en het GAK was de vaststelling van arbeidsongeschiktheid opgedragen aan de medische dienst', die daarvoor rapporteurs Ziektewet en verzekeringsartsen in dienst had. De medische dienst bracht verslag uit aan de uitkeringsafdeling, die al dan niet overging tot uitkering. De bedrijfsvereniging was formeel verantwoordelijk voor het besluit. In de praktijk werd een advies van de medische dienst vrijwel altijd opgevolgd. Het ziekengeld werd, behalve in het geval van werkloosheid, uitbetaald aan de werkgever. Bij werkloosheid werd de WW-uitkering bij ziekte stop gezet en het ziekengeld rechtstreeks aan de verzekerde uitbetaald. 
Op dit moment is de betaling vanuit de Ziektewet voor een groot deel van de werknemers buiten werking gesteld ${ }^{x}$ en vervangen door de Wet uitbreiding loondoorbetalingsplicht bij ziekte (Wulbz)'. Sinds 1 maart 1996 hebben werkgevers een loondoorbetalingsverplichting bij ziekte van hun werknemers gedurende de cerste 52 weken van het verzuim en ligt de verantwoordelijkheid voor de verzuimbeoordeling en begeleiding gedurende het hele 'ziektewetjaar' in handen van werkgevers. Werkgevers moeten zich bij de uitvoering van deze taken laten bijstaan door deskundigen. In de praktijk nemen veel instellingen daartoe een commercieel opererende Arbo-dienst in de $\mathrm{arm}^{10}$. Over de precieze diensten die deze Arbo-diensten aan werkgevers leveren worden contracten afgesloten. De facto ligt de beoordeling en begeleiding van verzuim gedurende de eerste 52 weken daarmee in handen van artsen in dienst bij de arbo-dienst. Naast die controlerende en begeleidende taken die voorheen door de Bedrijfsverenigingen werden uitgevoerd voeren deze nieuwe Arbo-diensten ook bedrijfsgezondheidstaken uit. De Uitvoeringsorganisaties (voorheen Bedrijfsverenigingen genoemd) houden een controlerende taak ten opzichte van de Arbo-diensten op het gebied van arbeidsongeschiktheidsbeoordelingen.

In de tussenliggende periode hebben werkgevers afhankelijk van de grootte van hun bedrijf een eigen risico-periode ten aanzien van het verzuim van hun werknemers gehad van twee of zes weken". Dat betekende dat werkgevers een loondoorbetalingsverplichting hadden en verantwoordelijk waren voor de verzuimcontrole en begeleiding gedurende de eerste 2 of 6 weken van het verzuim van de werknemer. Daarna namen de bedrijfsverenigingen deze taken over. Werkgevers konden hun verantwoordelijkheid voor verzuimbegeleiding en controle uitbesteden. In de overgangsperiode waren drie verschillende type diensten op dat terrein actief. In de eerste plaats de oude Bedrijfsverenigingen, ten tweede de Bedrijfsgezondheidsdiensten en ten derde nieuw opgerichte Arbodiensten $^{12}$.

Gedurende de participatieperiode van dit onderzoek trof de BVG maatregelen om op al deze veranderingen te anticiperen. Vanuit de BVG is in juni 1994, in samenwerking met anderen de Arbo-dienst 'Avios-Arbo' opgericht. Deze dienst heeft de sociaal-medische verzuimbegeleidingstaak van de BVG voor een groot deel over genomen. Een deel van het personeel is overgenomen door deze nieuwe ARBO-dienst. Instellingen die voorheen onder de BVG vielen hadden de mogelijkheid om de controle gedurende de eerste twee of zes weken zelf uit te voeren of door een andere dienst te laten verrichten. Indien instellingen daartoe geen uitdrukkelijk verzoek indienden werden deze taken automatisch overgenomen door Avios-Arbo. In ieder geval tot 1 januari 1995 heeft Avios-Arbo deze taken voor het grootste deel van de 'oude' BVG instellingen verricht.

De betrokkenheid van artsen bij de uitvoering van de Ziektewet werd gelegitimeerd door het feit dat het criterium voor arbeidsongeschiktheid gelegen is in het door ziekte of gebrek niet kunnen uitoefenen van de eigen werkzaamheden. Artsen, in het bijzonder 
verzekeringsartsen, zijn belast met de taak om te beoordelen of iemand al dan niet terecht een beroep doet op de wet. De taak van artsen is echter niet beperkt tot het constateren van door ziekte of gebrek veroorzaakte arbeidsongeschiktheid. In de Ziektewet wordt tevens aangegeven dat de geneeskundige het in het belang van de werknemer kan vinden dat deze passende arbeid verricht bij ongeschiktheid voor zijn eigen werk (art. $30)^{13}$, dat de werkgever in zulke gevallen verplicht is deze arbeid ter beschikking te stellen en dat de werknemer zich tijdig onder geneeskundige behandeling moet stellen, de geneeskundige voorschriften moet opvolgen en zijn genezing niet mag belemmeren (art,44). Voor verzekeringsartsen betekende dat, dat ze naast het vellen van een oordeel over de rechtmatigheid van het verzuim tevens tot taak hadden er voor te zorgen dat het verzuim tot een minimum beperkt werd. Deze taak werd meestal aangeduid als reïntegratiebevorderend of begeleidend. Deze op begeleiding en verzuimbeperking gerichte activiteiten zijn in de nieuwe situatie steeds belangrijker geworden.

\section{Proceduregang binnen de BVG}

Dit onderzoek richt zich op de verzekeringsgeneeskundige praktijken die bij de aanvang van het onderzoek in 1994 binnen de Bedrijfsvereniging voor Gezondheid, Geestelijke en Maatschappelijke belangen (BVG) waren gelokaliseerd. De BVG was bij de aanvang van het onderzoek verantwoordelijk voor de uitvoering van de Ziektewet bij de bij de BVG aangesloten bedrijven en instellingen. Zoals als de naam al aangeeft betreft dat instellingen in de sectoren gezondheidszorg en welzijn. Zoals gezegd zijn deze taken voor wat betreft de verzuimcontrole en begeleiding voor een groot deel overgenomen door AviosArbo. Later zijn daar ook bedrijfsgezondheidszorg taken aan toegevoegd.

De eerste maanden na de formele oprichting van de Arbo-dienst hebben zich slechts heel langzaam wijzigingen voltrokken in de structuur van de uitvoering. In eerste instantie deden dezelfde mensen op dezelfde locaties hetzelfde werk en was alleen hun werkgever veranderd (van BVG naar Avios-Arbo). Avios-Arbo heeft ook de instellingen en bedrijven voor wat betreft de ziektecontrole en begeleiding voor een groot deel van de BVG overgenomen. Het afsluiten van 'commerciēle' contracten met deze instellingen, die de mogelijkheid hadden om voor een andere Arbo-dienst te kiezen, is pas per 1 januari 1995 ingegaan.

In deze paragraaf zal ik beschrijven hoe de medische afdeling van de BVG vorm gaf aan haar controle en begeleidingstaak. Dat wil zeggen welke activiteiten door wie op welk moment werden uitgevoerd. Deze werkwijze is tijdens het onderzoek, ondanks de formele overname van deze taken door Avios-Arbo, niet gewijzigd. 


\section{Ziekmelding}

Een werknemer die wegens ziekte van mening is zijn of haar werk niet te kunnen doen, meldt zich ziek bij de werkgever. In veel instellingen is een zogenaamd verzuimprotocol van kracht, waarin regels en procedures ten aanzien van omgang met zieke werknemers binnen de instelling zijn geregeld. Naast ziekmeldingsprocedures zijn daarin afspraken vastgelegd ten aanzien van de omgang met verzuim door de instelling (zie verder onder verzuimbeleid binnen de instelling). Als werknemers opgenomen zijn in een intramurale instelling wordt dit eveneens vermeld. De zieke werknemer krijgt dan een formulier. waarop de datum van ontslag kan worden vermeld en dat wordt opgestuurd bij ontslag uit de instelling. Gedurende de opname vindt geen controle plaats door de BVG.

\section{Rapporteur ziektewet}

Een ziekmeiding van een werknemer komt bij de BVG binnen via de werkgever bij de administratie van de medische dienst. In principe wordt een zieke werknemers binnen enkele werkdagen bezocht door de rapporteur ziektewet van de BVG. De rapporteur ziektewet vult tijdens dit bezoek een formulier in, waarop naast naar persoonsgegevens gevraagd wordt naar de reden van het verzuim, de acties die iemand onderneemt/ondernomen heeft om van zijn ziekte af te komen (bezoek arts, therapie, medicijngebruik etc.) en de verwachting ten aanzien van de duur van het verzuim. De rapporteur heeft de bevoegdheid om, vanaf de dag van zijn bezoek toestemming te geven voor verzuim gedurende een periode van maximaal twee weken, indien de duur van het verzuim gezien de klachten redelijk lijkt. Als de zieke werknemer aangeeft dat hij of zij denkt dat het verzuim langer dan twee weken gaat duren verwijst de rapporteur ziektewet de werknemer door naar het spreekuur van de verzekeringsarts. De zieke werknemer wordt eveneens naar de verzekeringsarts doorverwezen als de rapporteur van mening is dat de zieke werknemer langer denkt te verzuimen dan gezien zijn klachten noodzakelijk is. Als de klachten van een zieke werknemer psychisch van aard zijn of werkgerelateerd volgt in principe altijd een verwijzing naar de verzekeringsarts, dus ongeacht de door de werknemer verwachte duur van het verzuim. De zieke werknemer ontvangt via de administratie van de BVG een oproep voor het spreekuur van de verzekeringsarts. Na opname in een intramurale gezondheidszorginstelling volgt na ontslag uit deze instelling meestal direct een oproep voor het spreekuur van de verzekeringsarts.

\section{Spreekuur verzekeringsarts}

Alle door de rapporteur doorverwezen zieke werknemers worden in principe binnen drie weken opgeroepen voor het spreekuur van de verzekeringsarts. Voorafgaande aan het spreekuur heeft de verzekeringsarts beschikking over het dossier van de ziek gemelde werknemer. Dat dossier bevat de aantekeningen van de rapporteur ziektewet over de ziekmelding in verband waarmee de werknemer is opgeroepen en, indien daar sprake van 
is, informatie over het zogenaamde verzuimverleden van de zieke werknemer: alle ziekmeldingen en de duur daarvan van de afgelopen jaren en dossieraantekeningen van de verzekeringsarts indien de werknemer in het verleden eerder een bezoek heeft gebracht aan de verzekeringsarts. De verzekeringsarts heeft voorafgaande aan het spreekuur geen beschikking over informatie ten aanzien van eventuele diagnose en behandeling van de klachten van de werknemer uit de zogenaamde curatieve sector.

De verzekeringsarts heeft tot taak te beoordelen of het verzuim van de werknemer rechtmatig is en om de werknemer, zo snel als redelijkerwijs mogelijk is, te begeleiden om terug te keren in zijn of haar werkzaamheden. Ten behoeve van deze begeleiding beschikt de verzekeringsarts over een aantal instrumenten. Op de eerste plaats kan de verzekeringsarts gebruik maken van een zogenaamde gedeeltelijke hervatting, waarbij de werknemer slechts een gedeelte van zijn of haar taken opneemt en/of slechts een deel van het aantal uren gaat werken. Op de tweede plaats is het mogelijk om mensen op arbeidstherapeutische basis te laten werken. Dat wil zeggen dat mensen werkzaamheden uitvoeren, zonder dat daar betaling tegenover staat. Werknemers zijn dan boventallig aanwezig en worden betaald uit de ziektewet. Tenslotte is er de mogelijkheid om mensen tijdelijk andere werkzaamheden te laten doen. Deze drie instrumenten worden vaak in combinatie gebruikt.

Alhoewel de verzekeringsarts in principe vrij is om de inrichting van de gesprekken met de zieke werknemer te bepalen, biedt de BVG ondersteuning in de vorm van een uitgewerkte systematiek voor gespreksvoering. Deze systematiek, het klein-werk-model $^{14}$ genoemd, is gebaseerd op het model van de argumentatieve claimbeoordeling. Het uitgangspunt van dit model is dat de zieke werknemer met een claim komt, namelijk dat hij of zij niet kan werken wegens ziekte. De zieke werknemer moet deze claim beargumenteren, de verzekeringsarts beoordeelt of de claim aannemelijk is, en of die aannemelijkheid gebaseerd is op ziekte. Daartoe beschikt de verzekeringsarts over de mogelijkheid om informatie op te vragen bij behandelend artsen en/of therapeuten van de zieke werknemer, voorzover deze daar toestemming voor geeft. Vervolgens beoordeelt de verzekeringsarts of de arbeidsongeschiktheid herstelbaar is, en, als dat het geval is, of de werknemer adequaat herstelgedrag vertoont. Het werkmodel bevat een vijftal thema's die in het gesprek ter sprake moeten komen, te weten, het inventariseren van de claim zelf, de redenen van de claim, het toetsen van de aannemelijkheid van de claim, het stellen van de prognose en het beoordelen van de gezondheid van de werknemer aan de hand van het gesprek. Deze vraaggebieden zijn echter te omvangrijk om binnen de tien minuten die staan voor een eerste gesprek te worden besproken. De thema's komen daarom meestal gedurende een aantal opeenvolgende gesprekken aan de orde. In het eerste gesprek staat met name de vraag centraal of de verzekeringsarts van doen heeft " met een 'pluis' geval (duidelijk arbeidsongeschikt die weldra effectief door de cliënt bestreden zal worden) of een 'niet-pluis' geval (onduidelijk of arbeidsongeschiktheid echt 
bestaat en/of risico's van langdurig verzuim al dan niet omdat het herstelgedrag insufficiënt is)" (De Boer, 1991). Voor een tweede gesprek is het mogelijk om twintig minuten te reserveren indien dat nodig is. Het klein-werk-model bevat voorbeelden van vragen en een opbouw voor het gesprek die het mogelijk moeten maken de tien minuten gesprekken efficiênt in te richten.

Het klein-werk-model is een handreiking aan verzekeringsarts, daarnaast is er een rapportageprotocol, waarin aangegeven wordt welke vraaggebieden in ieder geval in het gesprek aan de orde moeten komen en waarover gerapporteerd moet worden. De verslaglegging van verzekeringsarts wordt aan de hand van dit protocol steekproefsgewijs gecontroleerd.

\section{De arbeidsconsulent}

De verzekeringsarts kan in het kader van verzuimcontrole en begeleiding gebruik maken van de diensten van de arbeidsconsulent. De arbeidsconsulent is met name belast met arbeidskundige aspecten van het verzuim. Daarbij gaat het op de eerste plaats om het berekenen van loonwaarden, als werknemers gedeeltelijk hun eigen werkzaamheden uitvoeren of gedeeltelijk in vervangende werkzaamheden bezig zijn. Ten tweede adviseert de arbeidsconsulent over aanpassingen van de werkplek indien die nodig zijn om de reïntegratic van een werknemer mogelijk te maken. Op de derde plaats kan de arbeidsconsulent bemiddelen als er sprake is van arbeidsconflicten. De arbeidsconsulent voert dan gesprekken met de zieke werknemer, en met toestemming van de werknemer ook met de werkgever en eventueel met werknemer en werkgever gezamenlijk. De arbeidsconsulent werkt in opdracht van de verzekeringsarts en rapporteert ook aan de verzekeringsarts. De verzekeringsarts blijft verantwoordelijk voor adviezen ten aanzien van de arbeidsongeschiktheid en besluiten ten aanzien van aanpassingen etc.

\section{Werkorganisatie en intern overleg}

De rapporteur ziektewet, de verzekeringsarts en de arbeidsconsulent, aangevuld met een administratief medewerker, vormen samen een verzuimteam. De verzekeringsarts is teamleider en verantwoordelijk voor de werkzaamheden van zijn of haar teamgenoten. Het verzuimteam werkt in principe bedrijfsgericht, dat wil zeggen dat de verzuimcontrole en begeleiding van een aantal instellingen of bedrijven onder de verantwoordelijkheid van een team vallen. De rapporteur ziektewet rapporteert over zijn werkzaamheden aan de verzekeringsarts en vraagt in geval van twijfel om advies. Afhankelijk van het team, worden alle door de rapporteur bezochte werknemers besproken of komen alleen de gevallen waarmee de rapporteur geen raad weet aan de orde. Alle verzuimteams staan op hun beurt onder leiding van het hoofd medische dienst. Iedere maand rapporteert het team over haar werkzaamheden in de vorm van kwantitatieve gegevens. Ten tijde van 
het onderzoek was dit voornamelijk een administratieve procedure en werd dergelijke informatie voor kennisgeving aangenomen door het hoofd medische dienst.

\section{Sociaal Medisch Team}

Naast het houden van een spreekuur is het overleg met de werkgever een belangrijke taak van de verzekeringsarts. Bij grotere instellingen is dit overleg veelal geïnstitutionaliseerd in het zogenaamde Sociaal Medische Team (SMT). Het SMT is een regelmatig terugkerende bijeenkomst tussen de verzekeringsarts, de verantwoordelijke voor personeelsbeleid binnen de instelling (personeelsconsulent, hoofd personeelszaken, soms een directielid), indien aanwezig de bedrijfsarts, en in sommige gevallen direct leidinggevenden. De wijze waarop het SMT is ingevuld loopt sterk uiteen. Deze invulling is afhankelijk van zowel de ideeẻn en wensen van de instelling als die van de verzekeringsarts. Zo geven sommige instellingen aan geen behoefte te hebben aan adviezen van de artsen, en vindt het SMT in het geheel niet plaats. In andere situaties is ofwel de werkgever ofwel de verzekeringsarts met name geinteresseerd in de bespreking van opvallende of langdurige 'verzuimgevallen' en bestaat het SMT uit een bespreking van deze gevallen. In weer andere situaties hechten werkgever en/of verzekeringsarts veel waarde aan het gehele verzuimbeleid, en wordt in het overleg, naast de bespreking van individuele gevallen,

veel aandacht besteed aan de bespreking van verzuimstatistieken van de instelling, de betekenis van deze cijfers en mogelijke veranderingen binnen de instelling om verzuim terug te dringen.

\section{Het verzuimbeleid binnen de instelling}

Begin jaren ' 90 formuleert de BVG expliciet de taken van de werkgever ten aanzien van verzuim (BVG, 1992, 2). "hoewel de BVG een duidelijke taak heeft in verlaging van het verzuim, is het ziekteverzuim in de eerste plaats de verantwoordelijkheid van het management van de instelling". De BVG stimuleert instellingen om een verzuimbeleid te ontwikkelen dat uit drie onderdelen bestaat. 1) een registratie van het verzuim; 2) een verzuimprotocol; 3) de kwaliteit van arbeid en organisatie. De registratie van het verzuim vindt plaats op instellings- en afdelingsniveau en heeft tot doel inzicht te verschaffen in de ontwikkeling van het verzuim, op grond waarvan problemen gesignaleerd kunnen worden en preventief beleid ontwikkeld kan worden. Het verzuimprotocol regelt taken, verantwoordelijkheden en activiteiten van de verschillende betrokkenen binnen de instelling bij het begeleiden van individueel verzuim. Binnen de instelling heeft de direct leidinggevende vaak een belangrijke taak bij de verzuimbegeleiding, in de zin dat deze contact dient te onderhouden met de zieke werknemer en als eerste aanspreekbaar is om de mogelijkheden voor aangepaste werkzaamheden te bekijken. De aandacht voor kwaliteit van arbeid en organisatie is gericht op het bestrijden van de oorzaken van verzuim, 
onder andere op grond van signalen die naar voren komen in de eerste twee onderdelen van het verzuimbeleid.

\section{Contacten met de behandelende sector}

De verzekeringsarts heeft tot taak om de claimklacht van zieke werknemers te beoordelen en zieke werknemers te begeleiden gedurende het werkhervattingstraject. Veel zieke werknemers zijn voor hun klachten onder behandeling van een huisarts, een therapeut of een specialist. De verzekeringsarts heeft tot taak om zieke werknemers te stimuleren om hun klachten te verhelpen. Daartoe kan hij zicke werknemers aanmoedigen om zich onder behandeling te stellen. De verantwoordelijkheid van de behandeling van klachten ligt echter bij de 'behandelaars'. Ter ondersteuning van hun adviezen of oordelen ten aanzien van de werkhervatting kunnen verzekeringsartsen wel informatie inwinnen bij behandelend artsen. Voor de uitwisseling van informatie tussen verzekeringsartsen en curatief werkzame artsen zijn door de KNMG gedragsregels neergelegd in het 'Besluit en rapport inzake geneeskundige verklaringen, intercollegiale informatic en medische informatie', het zogenaamde "groene boekje". Daarin wordt aangegeven dat curatief werkzame artsen zich moeten onthouden van het verstrekken van geneeskundige verklaringen over arbeids(on)geschiktheid, maar dat betekent niet dat hij daarover geen advies mag geven. Uitgangspunt bij het verstrekken van intercollegiale informatic is in het algemeen dat pas informatie gevraagd wordt na een eigen onderzoek van en een voorlopig oordeel over de patiēnt en wel met diens toestemming. Alleen relevante (strikt noodzakelijke), objectiveerbare gegevens mogen worden verstrekt en in principe schriftelijk (KNMG, 1987; Cuypers e.a., 1992) ${ }^{15}$. In de praktijk maakten verzekeringsartsen weinig gebruik van de mogelijkheid om informatie op te vragen bij de curatieve sector.

Over de uitwisseling van informatie tussen verzekeringsartsen en de behandelende sector is in de loop der jaren veel gediscussieerd (Meershoek, 1993). Alhoewel beide partijen in deze discussie genuanceerde en veranderende opvattingen naar voren brengen, beweegt de discussie zich tussen twee tegengestelde argumentatielijnen. Onder verzekeringsartsen wordt regelmatig de klacht geuit dat de medewerking van behandelend artsen te wensen overlaat. Binnen de behandelende sector wordt de terughoudendheid ten opzichte van het verstrekken van informatie veelal erkend. De motivatie die binnen de behandelende sector wordt gegeven voor die terughoudendheid is gebaseerd op het beroepsgeheim en daarmee samenhangend de scheiding van controle en behandeling. Volgens deze argumentatie zou het verstrekken van informatie aan de verzekeringsarts een inbreuk kunnen betekenen op de vertrouwensrelatie tussen behandelend arts en patient gezien de controle taken die de verzekeringsarts uitvoert. Die vertrouwensrelatie kan worden geschaad omdat niet is uitgesloten dat de verzekeringsarts, uit hoofde van zijn functie, deze informatie gebruikt om besluiten te onderbouwen die tegen de wensen van de werknemer/patiënt ingaan. Bovendien moeten verzekeringsartsen adviseren ten behoe- 
ve van derden, waardoor het risico bestaat dat vertrouwelijke informatie in handen van derden (de werkgever) terecht komt. De belangrijkste argumenten die verzekeringsartsen tegen deze redenering in hebben gebracht zijn ten eerste dat hun werk veel minder controlerend van aard is dan voorgesteld wordt. Een groot deel van hun werkzaamheden is gericht op begeleiding en om die goed te laten verlopen onderhouden ook verzekeringsartsen wel degelijk een vertrouwensrelatie met de zieke werknemer. Bovendien zijn ook verzekeringsartsen gebonden aan het beroepsgeheim en zijn zij in hun advisering aan derden niet verplicht de medische informatie waar zij hun oordeel op baseren openbaar te maken.

De laatste jaren zijn beide partijen in toenemende mate overtuigd geraakt dat een goede samenwerking en informatieverstrekking tussen verzekeringsarts en behandelend arts ten goede komt aan de zieke werknemer (Post, 1994; Levi, 1994; KNMG, 1996). Desalniettemin is er nog steeds onenigheid over de vraag hoe die informatieverstrekking gestalte moet krijgen en welke informatie dan overgedragen zou moeten worden. Deze contacten zijn moeizaam, mede omdat een deel van zowel de behandelend artsen als de verzekeringsartsen hechten aan het principe van de scheiding van verantwoordelijkheden (Combé en Streng, 1991). Dat betekent dat de behandelend arts verantwoordelijkheid heeft over de behandeling en de verzekeringsarts over adviezen ten aanzien van arbeids(on)geschiktheid en werkhervatting. Met de komst van de Arbo-diensten is deze discussie opnieuw opgelaaid omdat de afhankelijkhieid van verzekeringsartsen ten opzicitte van de Arbo-diensten en de werkgevers is vergroot (Croon en De Boer, 1994; De Boer e.a. 1995; Spreeuwenberg, 1996). De eerder genoemde argumenten van behandelend artsen om terughoudend te zijn met het verstrekken van informatie hebben daardoor weer aan kracht gewonnen.

Het beoordelingswerk van de verzekeringsarts bestaat dus voor een belangrijk deel uit het voeren van gesprekken met zieke werknemers. Deze werknemers zijn over het algemeen door de rapporteur Ziektewet verwezen naar de verzekeringsarts. Bij de begeleiding maakt de verzekeringsarts gebruik van de arbeidsconsulent, die als een soort verlengde arm van de verzekeringsarts fungeert. Naast de gesprekken met de werknemer voert de verzekeringsarts overleg met de werkgever en heeft hij incidenteel overleg met behandelaars. In de gesprekken tussen werknemer en verzekeringsarts zijn de behandelend arts en de werkgever als relevante anderen aanwezig, in die zin dat over de rol en het functioneren van deze mensen wordt gesproken. 


\section{Opzet, methode en analyse}

Dit onderzoek heeft tot doel inzicht te bieden in de logica van de verzekeringsgeneeskundige praktijk. In het vorige hoofdstuk heb ik betoogd dat de logica van de verzekeringsgeneeskundige praktijk tot stand komt in het praktisch handelen, meer specifiek gedurende de interactie of onderhandelingen die plaats vinden tussen verschillende actoren. Om die logica inzichtelijk te maken is het noodzakelijk om een gedetailleerd beeld te krijgen van dat praktische handelen. Het gebruik van intensieve onderzoeksmethoden ligt daarbij het meest voor de hand. Omdat het onderzoek zich richt op interacties is gekozen om gebruik te maken van participerende observaties ${ }^{16}$.

Het uitvoeren van participerende observaties is een tijdrovende aangelegenheid. Daar het onmogelijk is om alles even uitgebreid te bestuderen heb ik me geconcentreerd op die activiteiten die direct gericht zijn op de arbeidsongeschiktheidsbeoordeling en begeleiding en omdat het hier gaat over de verzekeringsgeneeskundige praktijk beperk ik me daarbinnen tot die activiteiten waar artsen bij betrokken zijn. In concreto zijn dat op de eerste plaats de gesprekken tussen verzekeringsartsen en zieke werknemers. Ten tweede zijn dat de contacten tussen verzekeringsartsen enerzijds en 'externen' zoals de behandelend artsen en de werkgevers (Sociaal Medische Teams) anderzijds. Ten derde zijn dat contacten die artsen onderhouden met diverse betrokkenen binnen de instelling, zoals rapporteurs Ziektewet, arbeidsdeskundigen, en afdelingshoofden.

Om deze activiteiten te bestuderen heb ik in de periode mei- oktober 1994 gedurende vier maanden participerende observaties uitgevoerd op zes verschillende kantoren van de BVG. Op ieder kantoor van de BVG heb ik steeds twee weken meegelopen met één verzekeringsarts. 's Ochtends hielden deze verzekeringsartsen spreekuur en was ik aanwezig bij de gesprekken tussen verzekeringsarts en cliënten. In totaal zijn ongeveer 250 gesprekken geobserveerd. De cliënten die bij de verzekeringsarts op bezoek kwamen werd gevraagd om toestemming voor het bijwonen van het gesprek door de onderzoeker $^{17}$. In een klein deel van de gevallen (15) werd die toestemming geweigerd. Naar redenen voor deze weigering is niet gevraagd. Op basis van de informatie van verzekeringsartsen zijn er geen aanwijzingen om aan te nemen dat er een specifieke groep cliënten daardoor niet is geobserveerd (er zat geen patroon in naar bijvoorbeeld sekse, type klachten of type werk). 's Middags hadden de verzekeringsartsen verschillende activiteiten op het programma. Voor een groot deel waren dat administratieve werkzaamheden, telefonisch contacten etc. Ook vergaderingen en bezoeken aan instellingen voor de Sociaal Medische Teams waren vaak 's middags. In deze activiteiten heb ik geparticipeerd voor zover ze van belang waren voor het onderzoek. In totaal ben ik 12 keer mee geweest naar vergaderingen van Sociaal Medisch Teams. Daarnaast heb ik vergaderingen bijgewoond, heb ik gesprekken gevoerd met arbeidsconsulenten en ben ik mee geweest met rapporteurs Ziektewet en een enkele keer met de arbeidsconsulent. Van alle bijge- 
woonde gesprekken zijn gedurende de observaties gedetailleerde aantekeningen gemaakt. Die aantekeningen zijn zoveel mogelijk dezelfde dag verwerkt tot chronologische verslagen van de gesprekken ${ }^{18}$.

De primaire activiteiten van verzekeringsartsen in het kader van de arbeidsongeschiktheidscontrole en -begeleiding zijn het voeren van gesprekken met zieke werknemers en, in mindere mate, het voeren van gesprekken met werkgevers in het kader van de SMT's. Deze activiteiten staan centraal in dit onderzoek. Op basis van de verslagen van de participerende observaties is de logica van de verzekeringsgeneeskundige praktijk geanalyseerd. Deze verslagen bevatten twee onderdelen. Op de eerste plaats geven ze de interactie (het gesprek) tussen verzekeringsarts en werknemer respectievelijk werkgever weer. Ten tweede zijn ook de reacties van verzekeringsartsen voor en na deze gesprekken in de observatieverslagen verwerkt. De gesprekken zijn systematisch geanalyseerd. Het overige materiaal is meer gebruikt als achtergrond informatie voor de onderzoeker, die nodig was om de gebeurtenissen binnen de spreekkamer in een context te kunnen plaatsen. In de analyse wordt daar gebruik van gemaakt om op sommige punten de conclusies van de analyse te kunnen preciseren.

De analyse van de gesprekken zelf richt zich op de eerste plaats op de structuur van de gesprekken. Dat wil zeggen hoe ze zijn opgebouwd, wat er aan de orde komt en wat niet, hoe interactie-partners als vanzelfsprekend op specifieke manieren op elkaar reageren en reacties bepaalde reacties mogelijk maken en andere niet. Ten tweede is gekeken naar hoe die structurering van de gesprekken een specifieke werkelijkheid produceert. Dat wil zeggen hoe arbeidsongeschiktheid betekenis krijgt door of in die structurering, omdat er bepaalde dingen over gezegd en besproken worden terwijl andere onbesproken blijven. En daarnaast hoe actoren geconstitueerd worden in relatie tot interactiepatronen omdat gedurende het gesprek bepaalde gedragingen passen en andere niet. Die gedragingen en de afwijzende en stimulerende reacties construeren een bepaald type patiënt/cliënt en (re)construeren wat een verzekeringsarts is. Daarnaast worden in samenhang met de constructic van arbeidsongeschiktheid ook werkgevers en behandelend artsen geconstrueerd. Analytisch kunnen deze twee delen van de analyse, de structurering en de wijze waarop daarin werkelijkheid wordt geproduceerd, onderscheiden worden. In de praktijk lopen ze in elkaar over. Bij de analyse van het materiaal ben ik begonnen met het zoeken naar patronen, door de gesprekken met elkaar te vergelijken. Die vergelijkingen hadden in eerste instantie betrekking op het verloop van het gesprek, maar werden steeds abstracter. Inzicht in de logica van (delen) van het gesprek maakt het vervolgens mogelijk om de rationale van die structuur inzichtelijk te maken en afwijkende of opvallende zaken te verklaren. Ze geven aanknopingspunten om te begrijpen waarom sommige reacties niet passen en andere wel.

De reacties van verzekeringsartsen op de gesprekken vervullen een specifieke functie bij het analyseren van de logica van de praktijk. Verzekeringsartsen geven na afloop van 
de gesprekken een reconstructie van wat er in die gesprekken gebeurd is en waarom zij op een bepaalde manier hebben gereageerd. Die reconstructie is niet zozeer opgevat als een 'verslag' van het gesprek, maar geeft inzicht in welke zaken voor de verzekeringsarts kennelijk op het spel staan, bijzonder worden gevonden of gelegitimeerd moeten worden. Die reacties zeggen iets over het concrete gesprek of de concrete cliēnt, maar geven tevens aanknopingspunten om vanzelfsprekendheden en bijzonderheden in de praktijk op het spoor te komen. Voor dit onderzoek is vooral op die tweede manier naar deze reacties gekeken.

De identiteit van actoren wordt niet in specifieke fases van het gesprek geproduceerd, maar in het gesprek als geheel. Bij de verslaglegging van de analyse is er dan ook voor gekozen om niet de chronologie van het gesprek te volgen, maar om de hoofdstukken thematisch te ordenen. Deze thematische opzet heeft consequenties voor de wijze waarop het empirisch materiaal in de studie het verslag is verwerkt. Ter ondersteuning van de analyse worden fragmenten uit de gesprekken in de tekst opgenomen. Zij vormen de ondersteuning van de argumentatie in de diverse hoofdstukken. Er zijn geen integrale gesprekken in de tekst opgenomen. De centrale vraagstelling in dit boek is ook niet gericht op de letterlijke verloop van de gesprekken, maar op de logica van het geheel. De logica of het patroon dat in de interacties onderzocht wordt gaat niet in op letterlijke opeenvolging van precieze uitingen", maar op de samenhang tussen interactie-onderdelen en de wijze waarop zij 'realiteit' produceren.

Het systematische karakter van de analyse vindt zijn weerslag in de opbouw van het boek. In de empirische hoofdstukken staat steeds de constructie van de identiteit van éen van de actoren centraal. De constructie van arbeidsongeschiktheid en de identiteiten van actoren vindt echter in onderlinge wisselwerking plaats. Alhoewel het accent steeds op één van de actoren ligt, komen ook andere onderdelen in de hoofdstukken meer zijdelings aan de orde. In hoofdstuk drie staat de constructie van de cliënt centraal. In hoofdstuk vier de constructie van de behandelaar en in hoofdstuk 5 de constructie van de werkgever. De identiteit van de verzekeringsartsen komt in alle hoofdstukken aan bod, omdat zij in deze praktijk direct interacteren met alle drie deze actoren. Voor de constructie van arbeidsongeschiktheid geldt hetzelfde; dat is het product van alle interacties tezamen.

\section{Noten}

1. Generaliseren vindt hier plaats door abstractie. Deze opvatting ten aanzien van generaliseerbaarheid is gangbaar binnen het zgn. intensieve onderzoek (Van der Veen, 1990; Komter, 1983; Schuyt, 1986; Harré, 1979). Intensief onderzoek staat tegenover extensief onderzoek. Extensief onderzoek wordt gekenmerkt door de bestudering van een gering aantal kenmerken bij een voor een bepaalde populatie representatieve steekproef. Uitkomsten van dit type onderzoek is generaliseerbaar naar de populatie. De methoden die bij dit type onderzoek gehanteerd worden zijn bijvoorbeeld surveys. Intensief onderzoek probeent daarentegen 
de aspectrijkdom van verschijnselen $z 0$ veel mogelijk intact te laten en richt zich dan ook op gedetailleerde bestudering van beperkt aantal cases. Generaliseerbaarheid heeft hier geen betrekking op de populatie maar op het verschijnsel. Onderzoeksmethoden die voor intensief onderzoek worden gebruikt zijn bijvoorbeeld participerende observaties en diepte-interviews.

2. De Bedrijfsvereniging BVG bestaat inmiddels niet meer. Een deel van de taken en mensen die vroeger onderdeel uit maakten van de organisatie BVG zijn overgeheveld naar de Arbo-dienst Avios-Arbo. Het resterende deel van de BVG is gefuseerd met de voormalige bedrijfsvereniging DETAM (Bedrijfsvereniging voor detailhandel, ambachten en huisvrouwen) tot de uitvoeringsorganisatie CADANS. De eigenlijke bedrijfsvereniging is opgegaan in het Lisv.

3. Ambtenaren zijn verzekerd via het ABP (Algemeen Burgerlijk Pensioenfonds), dat een vergelijkbare regeling ten aanzien van loonderving ten gevolge van ziekte of gebrek kent (Veerman, 1990).

4. Letterlijk zijn de criteria als volgt geformuleerd:

'De verzekerde heeft bij ongeschiktheid tot het verrichten van zijn arbeid wegens ziekte recht op ziekengeld... Voor de toepassing van deze wet worden onder ziekte mede verstaan: a. zwangerschap en bevalling; b. gebreken' (art. $19 \mathrm{ZW}$ ); 'Arbeidsongeschikt, geheel of gedeeltelijk is hij die ten gevolge van ziekte of gebreken geheel of gedeeltelijk niet in staat is om met arbeid te verdienen, hetgeen gezonde personen met soortgelijke opleiding en ervaring....met arbeid gewoonlijk verdienen' (art. 5 AAW/art. 18 WAO). In de wet TBA, ingevoerd in augustus 1993 is het arbeidsongeschiktheidscriterium gewijzigd: 'arbeidsongeschikt, geheel of gedeeltelijk, is hij die als rechtstreeks en objectief medisch vast te stellen gevolg van ziekte of gebreken....

5. Het arbeidsongeschiktheidscriterium in de WAO had oorspronkelijk betrekking op passende arbeid (Arbeidsongeschikt.is hij, die ....buiten staat is om met arbeid, die voor zijn krachten en bekwaamheid is berekend en die met het oog op zijn opleiding en vroeger beroep hem in billijkheid kan worden opgedragen, ter plaatsen waar hij arbeid verricht of het laatst verricht heeft of op een naburig soortgelijke plaats te verdienen, hetgeen lichamelijk en geestelijk gezonde personen, van dezelfde soort en van soortgelijke opleiding, op zodanige plaats met arbeid gewoonlijk verdienen; art. 18). Met de invoering van de Wet Terugdringing Beroep op de Arbeidsongeschiktheidsregelingen (TBA) op 1 augustus 1993 is het begrip 'passend' vervangen door 'alle gangbare' arbeid, waarbij onder gangbaar algemeen geaccepteerde arbeid waartoe de werknemer gezien zijn beperkingen nog in staat is.

6. Een aantal grote bedrijven in Nederland heeft ten aanzien van de uitvoering van de ziektewet nooit of slechts voor een deel van de taken een beroep op de Bedrijfsverenigingen gedaan. Deze bedrijven, de zogenaamde Akers (Afdelingskassen en eigen risico-dragers) hielden de uitvoering van de ziektewet geheel of gedeeltelijk in eigen beheer (Veerman, 1990).

7. De inrichting van de medische dienst en de organisatie van de verzuimcontrole verschilt per bedrijfsvereniging.

8. De Ziektewet is nog wel van kracht als vangnet voor bepaalde groepen. Hiertoe behoren onder andere uitzendpersoneel, mensen die niet op basis van een arbeidsovereenkomst werkzaam zijn (thuiswerkers of oproepkrachten), zieke werklozen.

9. Zie voor een uitvoerig overzicht van de regelgeving ten aanzien van de omgang met zieke werknemers: Ascher-Vonk c.a. 1997).

10. Afhankelijk van de bedrijfstak is de effectuering van de plicht van werkgevers om zich te laten bijstaan door deskundigen ingegaan per 1 januari 1996 of per I januari 1998. Voor een deel van de taken geldt de verplichting dat werkgever zich laat bijstaan door een gecertificeerde Arbo-dienst. Die verplichting is vastgelegd in de Arbeidsomstandighedenwet (Grevelingen en Waanders, 1995). 
11. De loondoorbetalingsverplichting voor werkgevers gedurende de eerste 2.6 weken van het verzuim is geregeld middels de Wet terugdringing ziekteverzaim (TZ), die in werking is getreden op 1 januari 1994 (Grevelingen en Waanders, 1995).

12. Deze taken voor de werkgever zijn geregeld in de Arbeidsomstandighedenwet. Middels de wijzigingen in deze wet (van kracht sinds I januari 1994) is de werkgever verplicht een zogenaamd vermuimbeleid te voeren, waaronder deze taken vallen. Het toezicht van de bedrijfsvereniging/uitvoeringsorganisatie is geregeld in de Wet Terugdringing Ziekteverzuim (Grevelingen en Waanders, 1995).

13. Dit artikel heeft gedurende de overgangsperiode naar de WULBZ aan betekenis gewonnen. Alhoewel het ook voobr 1994 was opgenomen in de Ziektewet, werd van deze herplaatsingsmogelijkheden nauwelijks gebruik gemaakt.

14. Het klein-werk-model is afgeleid uit het groot-werk-model, een gespreksprotocol dat gebruikt werd in de tijd dat zieke werknemer pas na 3 maanden op het spreekuur van de verzekeringsgeneeskundige verscheen en dat gesprek 45 minuten duurde. Gedurende de eerste drie maanden van het verzuim werd de zieke werknemer gecontroleerd door zgn. huisartsverzekeringsgeneeskundige. In 1992 is de inrichting van de controle veranderd conform het in dit hoofdstuk beschreven werkwijze.

15. Het besluit dateent van 1982 is in de loop der jaren een aantal keren herzien (KNMG, 1987; 1991). Nieuwe richtlijnen over het omgaan met medische gegevens zijn opgesteld in 1995 (KNMG, 1995). Tijdens het onderzock was de oude regeling dus nog van kracht.

16. Zie ook noot I van dit hoofdstuk.

17. Cliênten kregen een brief van de onderzoeker waarin kort de doelstelling van het onderzoek stond uitgelegd en werd aangegeven dat de aanwezigheid van de onderzoeker noch de weigering tot medewerking van invloed zou zijn op de beoordeling. Deze brief kregen cliênten als zij zich met hun oproep voor het spreekuur meldden bij de receptic. Aan de receptie konden zij ook doorgeven als ze bezwaren hadden tegen aanwezigheid van de onderzoekster bij hun gesprek met de verzekeringsarts. De verzekeringsartsen haalden de oproep voor het spreekuur op bij de receptie voordat zij de cliênt uit de wachtkamer opriepen. Als op de oproep stond aangetekend dat de cliênt bezwaar had tegen de aanwezigheid van de onderzoekster, werd ik eerst uit de spreekkamer gehaald en werd de cliënt daama pas opgehaald.

18. Tijdens deze gesprekken zijn aantekeningen gemaakt, die meestal dezelfde dag ten behoeve van de analyse zijn uitgeschreven. De gespreksfragmenten die in de volgende hoofdstukken gebruikt worden zijn geen letterlijke weergaven. De aantekeningen waren wel dusdanig gedetailleerd dat de lijn van het gesprek en de kern van iedere opmerking weergegeven kunnen worden.

19. Zoals bijvoorbeeld wel in conversatic-analyse gebruikelijk is. 



\section{Wat vindt $u$ er zelf van ?}

\section{- de constructie van de zieke als werknemer -}

\section{Inleiding}

De logica van het handelen in de verzekeringsgeneeskundige praktijk produceert 'realiteit', dat wil zeggen dat fenomenen en subjecten een specifieke lokaal geconstrueerde vorm krijgen. In dit eerste empirische hoofdstuk staat de wijze waarop in deze logica cliënten (belanghebbenden of zieke werknemers) geconstrueerd worden centraal. Deze constructie vindt gelijktijdig en in samenhang met andere onderdelen van deze praktijk plaats, zoals bijvoorbeeld de definiëring of constructie van arbeidsongeschiktheid of de verzekeringsartsen. Die laatste twee komen in dit hoofdstuk alleen zijdelings aan de orde en zullen in de volgende twee hoofdstukken verder worden uitgewerkt.

Voor het analyseren van het constructieproces van de cliënten vormen de gesprekken tussen verzekeringsartsen en zieke werknemers het uitgangspunt. De vraag is op welke wijze de constructie van cliènten tot stand komt in de gesprekken. Dat wil niet zeggen dat andere activiteiten op andere plaatsen geen bijdrage leveren aan de constructies van zieke werknemers, of dat het kader of de context waarbinnen het gesprek plaats vindt niet relevant is. Dat kader wordt in dit onderzoek echter niet op voorhand als gegeven beschouwd. De rol die verschillende onderdelen uit dat kader spelen in de gesprekken, of spelen in de logica van de praktijk vormt een onderdeel van de vraag. Het gaat immers om de eigen logica van de praktijk. Wat bijvoorbeeld de invloed van wet- en regelgeving is op datgene dat in de gesprekken gebeurt en in hoeverre verzekeringsartsen op grond van het wettelijk kader een betere of machtiger positie innemen dan zieke werknemers, vormen vragen die niet a priori beantwoord kunnen worden, maar waarvan het antwoord afhankelijk is van de context. Hoe dergelijke elementen die praktijk vorm geven is namelijk afhankelijk van de wijze waarop ze gereproduceerd worden.

Om het constructieproces van de zieke werknemer in de interactie te analyseren zal ik in dit hoofdstuk de stijl van de gesprekken tussen zieke werknemers en verzekeringsartsen bespreken. Ik zal laten zien dat verschillende onderdelen van het gesprek, zowel door de wijze waarop ze worden vorm gegeven als door de inhoud van de gespreksagenda, gezamenlijk een specifiek type cliënt tot stand brengen.

In de eerste paragraaf ga ik in op de rolverdeling tussen verzekeringsartsen en zieke werknemers in de interactie. Die rolverdeling komt in het begin van het gesprek expliciet aan de orde, maar transformeert gedurende de interactic. In deze paragraaf ligt het accent op de begin-fase van het gesprek. In de tweede paragraaf ga ik in op de probleemdefini- 
ering die in de gesprekken tot stand komt. Die probleemdefini ëring vormt een expliciet onderwerp in de tweede fase van het gesprek, maar loopt door het hele gesprek heen en heeft consequenties voor de rolinvulling of constructie van werknemers en verzekeringsartsen. De derde paragraaf gaat in op het creëren van commitment door te kijken naar de wijze waarop in latere fases van het gesprek, in lijn met de probleemdefiniëring handelingsopties geconstrueerd worden en interactiepartners aan die opties worden gebonden. In de vierde paragraaf komen mechanismen aan de orde die het karakter van vertrouwen geven of reguleren kennen. In de conclusie kom ik terug op de vraag hoe middels deze mechanismen een specifieke 'zieke werknemer' geconstrueerd wordt.

\section{Het voorstel voor een rolverdeling}

"..en daarbij ben ik vooral geinteresseerd in uw eigen mening.."

Als zieke werknemers voor de eerste keer op het spreekuur van de verzekeringsarts komen, worden zij op een bepaalde manier ontvangen. De verzekeringsartsen beginnen met een korte introductie, waarin zij de bedoeling van het gesprek uiteenzetten.

Ik zal u eerst even uitleggen wat de bedoeling is van dit gesprek. Ik ben arts bij de BVG. U heeft zich op 16 mei ziek gemeld. In dit gesprek gaan we uit van de situatie mu. Ik ga u eerst wat vragen stellen over of u nu uw werk weer zou kunnen doen, daarbij wil ik vooral uw eigen oordeel weten. Het gesprek duurt ongeveer 10 minuten en aan het einde van het gesprek moet ik een oordeel vellen over of $u$ uw huidige werk kunt doen of niet.

Dit is uw eerste oproep, ik zal u eerst even uitleggen hoe het gaat. $U$ bent opgeroepen in verband met de ziekmelding van 24 juni. Wij maken afspraken met betrekking tot het werk. We lopen zo eerst even de administratic langs, dan kijken we wat $u$ er van vindt, eventueel doe ik lichamelijk onderzoek en aan het einde van het gesprek bespreken we de conclusies.'

Op het eerste gezicht lijken dit tamelijke zakelijke introducties waarin de verzekeringsartsen aangeven waar het gesprek over gaat, wat van de zieke werknemer verwacht wordt en hoe hun eigen rol zal zijn. De precieze betekenis van wat in de introductie gezegd wordt krijgt gedurende het gesprek verder vorm. In de introductie wordt daarvoor een kader gezet. In die zin doet de introductie dan ook veel, ook al is de betekenis van wat er gezegd wordt niet precies gegeven en blijken zieke werknemers, zoals we verder in het hoofdstuk zullen zien, deze 'kaderstelling' lang niet altijd zonder meer te accepteren.

Op de eerste plaats vallen verzekeringsartsen niet met de deur in huis, maar brengen zij de zieke werknemer op de hoogte van de doelstelling van het gesprek. Het gesprek heeft een specifiek doel en door dat expliciet te formuleren wordt tot uitdrukking ge- 
bracht dat de zieke werknemer mede verantwoordelijk is voor het bereiken van dat doel. Daarmee wordt een beroep gedaan op de competentie van de zieke werknemer als een redelijke gesprekspartner.

Daarnaast doen de verzekeringsartsen een beroep op de verantwoordelijkheid van de werknemer in dat proces van naar het doel toe werken. In de rolverdeling die geformuleerd wordt krijgen zieke werknemers een actieve rol toebedeeld. Enerzijds wordt het gezamenlijke karakter van 'de onderneming' uitgedrukt, ".gaan we wit.". ".we maken afspraken.". En anderzijds worden de verantwoordelijkheden van beiden afzonderlijk benoemd. Van de zieke werknemer wordt verwacht dat hij zijn eigen mening geeft over zijn situatie; de verzekeringsarts legt uit, stelt vragen, doet eventueel lichamelijk onderzoek, wil dingen weten en oordeelt uiteindelijk over de situatie. De zieke werknemer, en daar concentreer ik me in dit hoofdstuk op, is mede verantwoordelijk voor het laten slagen van de doelstellingen. Die verantwoordelijkheid bestaat voor een belangrijk deel uit het geven van zijn of haar mening of oordeel over de situatie. De verzekeringsartsen beschouwen werknemers niet als passieve objecten, maar als actieve deelnemers, die geacht worden iets over hun eigen situatie te vinden. Dat vereist een bepaalde mate van distantie ten aanzien van die eigen situatic. De verzekeringsartsen spreken werknemers niet alleen aan als competente gesprekspartners, maar ook als mensen die over de competentie beschikken om hun eigen situatie te analyseren ${ }^{2}$.

Met het tonen van interesse voor de mening of het oordeel van de zieke werknemer introduceren verzekeringsartsen een open houding ten aanzien van de werknemers. Het gaat in het gesprek over diens opvattingen. Tegelijkertijd bakenen ze het gesprek in de introductie al af. Het draait om de situatie nu en niet over het verleden; het gesprek gaat over werk, en niet over bijvoorbeeld de klachten.

Tenslotte geven verzekeringsartsen met het benadrukken van bepaalde aspecten die in het gesprek centraal staan, namelijk de eigen opvattingen van de werknemer, het werk en de situatie nu, een meer impliciete boodschap. Verzekeringsartsen anticiperen op een mogelijke veronderstelling van cliënten ten aanzien van de vraag wat van hen verwacht wordt in het gesprek. Die veronderstelling heeft betrekking op het feit dat cliënten zich niet bewust zouden zijn van het verschil tussen verzekeringsartsen en behandelend artsen en er bovendien een tamelijk traditioneel beeld op na houden van arts-patiênt contacten in de curatieve sector. De verzekeringsartsen houden rekening met de mogelijkheid dat de werknemer er van uit gaat met een 'gewone' arts-patiënt situatie van doen te hebben. waar hij of zij zijn klachten en de voorgeschiedenis uit de doeken doet en de arts aangeeft wat er aan de hand is en wat er moet gebeuren. Impliciet bakenen verzekeringsartsen hun rol af ten opzichte van die van gewone artsen, en brengen zij tot uitdrukking dat ook cliënten niet de 'gewone' patiëntenrol op zich behoren te nemen. Er wordt van cliënten een actieve bijdrage verwacht en de informatie die verzekeringsartsen willen horen heeft geen betrekking op de voorgeschiedenis en de diagnose van de curatieve 
sector, maar op de situatie nu in het licht van het werk en het eigen oordeel van de cliënt. Er wordt cliënten duidelijk gemaakt dat de rol van de yerzekeringsartsen en het gesprek gepositioneerd moeten worden in het kader van de arbeidsrelatie van de cliënten en de verplichtingen die die relatie met zich meebrengt de achtergrond vormen van het gesprek.

In de ogenschijnlijk neutrale introductie die verzekeringsartsen geven wordt dus al een vrij specifiek kader van het gesprek naar voren gebracht. We zullen in de volgende paragrafen zien dat de drie boven genoemde elementen in de rolverdeling en het verwachtingspatroon van verzekeringsartsen ten aanzien van de cliënten in het gesprek steeds terugkerende thema's zijn.

\section{De werkhervatting als probleem van de cliënt}

". zoals het nu is, zou u uw werk weer kunnen doen."

In de introductie van de gesprekken plaatsen verzekeringsartsen cliënten in de rol van competente gesprekspartners. Cliënten worden geacht actief deel te nemen aan het gesprek en een bijdrage te leveren aan het tot stand brengen van de doelstelling van dat gesprek. In kort bestek krijgen cliënten een eerste indicatie van wat binnen de orde van dat gesprek valt en wat niet.

Wat binnen de orde van het gesprek valt, of het onderwerp waar het gesprek over gaat, wordt door verzekeringsartsen op de agenda gezet. In de wijze waarop verzekeringsartsen het gesprek verder opbouwen, de vragen die zij stellen en de volgorde daarvan, worden thema's binnen maar impliciet ook thema's buiten de orde van het gesprek geplaatst. De vragen construeren het probleem dat aan de orde is. De probleemdefiniering is niet zozeer een 'bewust' moment, in de zin dat de interactiepartners stil staan bij de vraag waar ze het over zullen hebben. Ze ligt veeleer besloten in de wijze waarop het gesprek vorm krijgt: de vragen die worden gesteld, de antwoorden die daarop komen en de volgorde die daarin optreedt. Die probleemdefinië ring heeft invloed op hoe cliënten geacht worden zich te gedragen. Deze paragraaf gaat in op verschillende onderdelen van het gesprek waar de probleemdefiniëring aan de orde is. Op de eerste plaats is dat bij de wijze waarop de gesprekken tussen verzekeringsartsen en cliënten ingezet worden. Ten tweede komen onderdelen aan de orde waar verzekeringsartsen 'onderhoudswerkzaamheden' plegen om de probleemdefinitie voortdurend centraal op de agenda te houden. Ten derde gaat het over de wijze waarop problemen samengevat worden.

\section{Het gaat over werk}

De eerste fase van de gesprekken tussen werknemer en verzekeringsarts kent een grote uniformiteit. Enerzijds wijst dat op (daadwerkelijk) gebruik van de handleiding voor het 
voeren van gesprekken ${ }^{3}$ die verzekeringsartsen door de BVG aangereikt hebben gekregen. Anderzijds geeft die uniformiteit aan dat verzekeringsartsen in deze fase van het gesprek grote invloed hebben op de probleemdefini ëring. Na de introductie en de bespreking van wat administratieve en persoonsgegevens van de zieke werknemer, vervolgt men het gesprek met een vraag van de volgende strekking:

va: $\mathrm{U}$ heeft zich 16 mei ziek gemeld, dat is nu ruim twee weken geleden. Zou u op dit moment uw werk weer kunnen doen?

De vraag "zou u op dit moment weer kunnen werken" is op het eerste gezicht een wat merkwaardige vraag. Als cliênten hun werk denken te kunnen doen, ligt het meer voor de hand dat ze aan het werk gaan en niet op het spreekuur van de arts verschijnen. De vraag fungeert in het gesprek dan ook niet zozeer als een reële vraag of iemand mogelijkerwijs al weer aan het werk zou kunnen, maar behelst eerder een statement waarin het onderwerp van het gesprek wordt benoemd: kan iemand werken of niet. De vraag dient als introductie om de klachten van werknemers op een specifieke wijze te bespreken. Het ontkennende antwoord van de zieke werknemer dat meestal volgt, vormt een specifieke opstap om de klachten ter sprake te brengen.

\footnotetext{
cl: nee, dat kan niet.

va: waar merkt $u$ aan dat het niet gaat?

cl: de stress, het werk maakt me gek, ik kan niet slapen, ik vergeet alles .. ik kan me niet concentreren,.
}

De vraag "waar merkt $\mathrm{u}$ aan dat het niet gaat" heeft betrekking op concrete handelingen die de zieke werknemer niet meer kan doen en die hij of zij zelf ervaart. Het probleem dat aan de orde is betreft niet zozeer de lichamelijke klachten, maar de concrete belemmeringen die werknemers bij het uitvoeren van hun werk tegen komen. Die problemen moeten expliciet worden geformuleerd. Bij zaken als vergeetachtigheid en concentreren, zoals in bovenstaand voorbeeld, is vanzelfsprekend duidelijk dat het belemmeringen betreft die de werkhervatting in de weg staat. In andere gevallen is niet meteen helder dat de klachten belemmeringen opleveren. Er wordt dan een extra stap gezet om de problemen op de juiste wijze te definiëren.

\footnotetext{
va: waar merkt $\mathrm{u}$ aan dat $\mathrm{u}$ niet kan werken?

cl: de stem, ik ben hees en ik heb last van branderige ogen.

va: en wat zijn dan precies de beperkingen?

cl: door die stem ben ik erg moeilijk verstaanbaar, en de kinderen worden er bang van.
} 
Alhoewel de man concreet benoemt waar hij last van heeft, wordt niet duidelijk welke belemmeringen dat oplevert voor de uitvoering van zijn taken. De man moet de relatie tussen klachten en zijn taken expliciteren. Hij werkt als maatschappelijk werker en begeleidt gezinnen waarin sprake is van opvoedingsproblemen. De moeilijkheden die hij ondervindt bij het praten vormen pas een probleem als hij kan duidelijk maken dat hij daardoor die begeleiding niet goed kan uitvoeren.

Dat de vraag 'waar merkt u dat aan' een specifieke probleemdefiniëring naar voren brengt en inderdaad opgevat moet worden als een vraag naar concrete beperkingen die zieke werknemers zelf ervaren en die van belang zijn voor de uitvoering van hun werk, wordt nog duidelijker op het moment dat zieke werknemers een ander antwoord geven.

va: waaraan merks $u$ dat het niet meer gaat?

cl: ik heb veel te veel pijn. Ik ben bij de neuroloog geweest, die zag ook dat het niet goed zat. Nu moet ik naar een academisch ziekenhuis.

va: wat zijn precies de klachten? waardoor gaat het niet?

De vrouw beantwoordt de vraag 'waaraan merkt $\mathrm{u}$ dat het niet meer gaat' niet met concrete klachten. Ze noemt dat ze pijn heeft, en stapt daarna over op het behandelingstraject dat ze doorloopt vanwege die klachten. De verzekeringsarts negeert dit antwoord en herformuleert de vraag door explicieter naar klachten te vragen. Alhoewel het behandelingstraject vanuit een medische probleemdefinitie alles te maken heeft met klachten, doet dat traject vanuit de vraag welke handelingen iemand niet meer kan doen op zijn werk niet ter zake. Pas als duidelijk is welke problemen de werknemer op zijn werk ondervindt wordt het eventueel interessant om op dat behandelingstraject in te gaan. In de opbouw van het gesprek zoals de verzekeringsarts die ziet is het behandelingstraject (nog) niet aan de orde. De verzekeringsarts probeert dat aan de werknemer duidelijk te maken door de inhoud van het antwoord te negeren en de oorspronkelijke vraag te herformuleren. Soms verwijzen verzekeringsartsen expliciet naar hun gespreksagenda voor zij hun vraag herhalen of herformuleren.

\footnotetext{
va: waaraan merkt u dat?

cl: na een half uur lopen begin ik te sloffen, heb ik pijn in m'n schaambeen en rug, daar krijg ik nu fysiotherapie voor.

va: we komen dadelijk terug op de fysiotherapie, u heeft problemen met lopen, heeft u nog andere klachten?

cl: ik ben moe, ik heb een loodzwaar been en een vaginale infectie.
}

De verzekeringsarts geeft hier expliciet aan dat de behandeling van de klachten later in het gesprek aan de orde komt, om vervolgens zijn oorspronkelijke vraag in een andere formulering te herhalen. Het bespreken van de therapie of behandeling is, zo blijkt, een 
niet-passend antwoord op de vraag 'waar merkt $\mathrm{u}$ aan dat het niet meer gaat'. De vraag 'waar merkt u aan dat het niet meer gaat' kan weliswaar opgevat worden als een vraag naar bijvoorbeeld de diagnose die in de curatieve sector is gesteld, binnen de probleemdefiniēring die de verzekeringsarts stelt is die diagnose (nog) niet relevant. Een tweede regelmatig terugkerend niet-passend antwoord is een verwijzing of bespreking van de ziektegeschiedenis. Ook hier proberen verzekeringsartsen door herhaling of herformulering van de vraag hun oorspronkelijke agenda, die begint met de vraag 'waarom kunt u niet werken', vast te houden. Verzekeringsartsen slagen daar niet altijd in.

va: zou u nu weer aan het werk kunnen?

cl: nou, ik heb griep gehad.

va: ik wil het eerst even over het mu hebben, dan komen we daama terug op de geschiedenis.

cl: ik heb een drukkend gevoel op de borst, want ik heb griep gehad, daar heb ik te lang mee gelopen, ik had een heel zwaar gevoel, slijm bij het hoesten, keelpijn en een zware verkoudheid.

va: maar wat kunt u op dit moment niet?

cl: ik ben snel moe, ik heb gerust.

va: is dat een probleem of een advies?

cl: nou, de fysiotherapeut heef ' $\mathrm{t}$ voor geschreven.

va: de huisarts heeft u doorverwezen naar de fysiotherapie?

cl: ja, ik heb een injectie in de knieěn gehad, want daar had ik pijn, dat heeft niet geholpen en toen moest ik naar fysiotherapie.

va: en wat zijn de problemen?

cl: buigen en strekken.

va: wat is het probleem ten aanzien van uw werk, de knieên of de vermoeidheid?

cl: Nou de vermoeidheid weet ik nog niet, want ik heb nog niet gewerkt.

De verzekeringsarts vraagt de vrouw of ze nu weer aan het werk kan. De vrouw begint daarop haar ziektegeschiedenis te vertellen, en ondanks het feit dat de verzekeringsarts haar tot twee keer toe onderbreekt om nogmaals te vragen wat er op het moment van het spreekuur nog aan de hand is, gaat ze door met haar verhaal. De probleemdefinitie van de verzekeringsarts, die samengevat kan worden met de vraag: 'wat kunt u niet op uw werk' is een andere dan die van de cliënt: 'ik kan niet werken want dat ik moet rust houden van de fysiotherapeut'. Verzekeringsarts en werknemer verschillen in bovenstaand fragment van mening over de vraag waar het gesprek over moet gaan. Voor de verzekeringsarts is van belang wat de belemmeringen zijn die de werknemer ervaart op het moment van het gesprek. De ziektegeschiedenis is voor de verzekeringsarts (nog) niet interessant. De vrouw zelf echter lijkt te veronderstellen dat zij haar afwezigheid op het werk moet legitimeren door te bewijzen dat ze 'echt' ziek is. Die legitimering ligt voor haar in het verleden, in de reden waarom ze is gestopt met werken en zich heeft ziek gemeld. Ze vertelt dingen die ze ook haar huisarts heeft verteld en verwacht dat de verzekeringsarts daarin geinteresseerd is. Haar antwoord verwijst naar een medische 
definitie van 'klachten'. Ondanks pogingen van de verzekeringsarts om haar te laten vertellen wat ze nu op haar werk merkt van de klachten, blijft ze die ziektegeschiedenis centraal stellen. De vrouw probeert de verzekeringsarts te 'overtuigen' van het belang van haar probleemdefinitie en de verzekeringsarts gaat daar even in mee, om na die bespreking weer terug te komen op zijn eigen probleemdefinitie. In de volgende paragraaf zullen we echter zien dat de onderhandeling over de probleemdefinitie in de loop van het gesprek voortdurend terug komt.

In de eerste fase van de gesprekken tussen verzekeringsartsen en zieke werknemers wordt een specifieke probleemdefinitie geconstrueerd. De vraag 'zou u nu uw werk kunnen hervatten' introduceert het probleem: de werkhervatting. En de vragen die daarop volgen moeten leiden tot een concretisering van dat probleem. Niet de 'medische' klachten maar de belemmeringen voor de werkhervatting worden geêxpliciteerd.

\section{Contacten op het werk}

Het vasthouden van dit werkgebonden perspectief staat niet op zich, maar speelt een belangrijke rol in het hele gesprek. Verzekeringsartsen moeten moeite doen om die werkhervatting als centraal probleem op de agenda te houden. Ze doen dat door het onderwerp vroeg te introduceren om er op een later tijdstip in het gesprek op een voor de hand liggende manier op terug te kunnen komen en door een aantal vragen in de loop van de gesprekken steeds te laten terugkeren. Die vragen dwingen werknemers steeds weer opnieuw over hun werkhervatting na te denken.

Verzekeringsartsen vragen bijvoorbeeld vrijwel altijd na het bespreken van de persoonsgegevens wat de werknemer van zijn of haar werk vindt.

\footnotetext{
va: hoe zou u uw werk typeren? zwaar, middelmatig of licht?

cl: lichamelijk niet zwaar, maar geestelijk wel. Door de hoeveelheid, het is nooit genoeg, en door de complexiteit m.n. door die samenwerking.

va: sou u op dit moment uw werk weer kunnen doen?
}

De antwoorden van werknemers op deze vragen zijn kort, ja, of nee, soms geestelijk niet, maar lichamelijk wel of andersom. Als de werknemers het werk zwaar vinden geven ze soms een korte toelichting. Verzekeringsartsen vragen niet of nauwelijks door op het antwoord van de werknemer. De vraag wordt gesteld om later op terug te kunnen grijpen en tijdens het gesprek makkelijker van het bespreken van de klachten over te kunnen gaan naar de bespreking van de werkhervatting. Zo vertelt één van de verzekeringsartsen na afloop van een gesprek:

Ik vraag altijd eerst naar de persoonsgegevens, dan staat het werk op de agenda, dan kan ik makkelijk vragen of ze het werk zwaar of leuk vinden, dan vergeet ik dat niet en kan er naar terugkoppelen. 
Een tweede type vraag dat in het eerste gesprek, maar ook in de daaropvolgende gesprekken altijd terug keert is de vraag naar contacten met de werkgever ${ }^{5}$. Verzekeringsartsen geven zelf aan dat het contact met het werk belangrijk is, om werkhervatting in een later stadium gemakkelijker te laten verlopen. Hoe langer iemand uit de roulatie is, hoe moeilijker het wordt om terug te keren. Het onderhouden van contacten met het werk en daardoor weten wat er gaande is, verlaagt de drempel voor werknemers om terug te keren. In gesprekken waar een werkhervatting nog niet aan de orde is, wordt deze vraag meestal ook gesteld, en lijkt hij wat in het luchtledige te hangen.

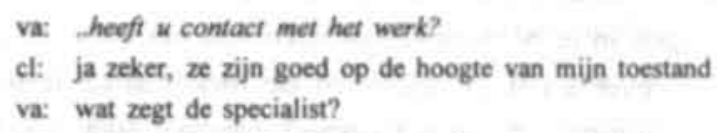

De vrouw geeft aan dat ze contact heeft met de werkgever. De verzekeringsarts gaat vervolgens over op een nieuw onderwerp. Als belanghebbenden geen contact onderhouden, zet de verzekeringsartsen ze daartoe aan.

cl: de sfeer op het werk is niet goed, soms wordt het me te veel, er wordt nu ook gestolen, en we draaien veel overdiensten, als iemand ziek is, komt er geen ander voor:

va: heeft u deze problemen wel eens op het werk besprokem?

cl: nee, niet echt.

va: dat moet $u$ wel doen, gaat u maar eens praten bij personeeiszaken.

cl: ik weet het niet, ik moet me eerst beter voelen.

va: ja, maar de klachten hebben juist met het werk te maken, daarom moet u gaan praten. $U$ maakt een afspraak met personeelszaken. Ik bespreek het ook met de werkgever.

cl: misschien is het toch wel goed.

De vraag naar contacten met de werkgever komt ook in de latere gesprekken terug, en dat onderwerp is dan (soms) een opstapje om de overgang naar het voorbereiden van de werkhervatting te maken.
va: heeft u contact met de werkgever?
cl: nee, dat ligt een beetje moeilijk, er is een nieuwe leidinggevende, maar die is ziek, er is nu een invalster en ik heb geen zin om daar nu weer kennis mee te maken.
va: hoe ziet $u$ de toekomst wat werk betreft?

Vanuit het bespreken van contacten met de werkgever is het makkelijk om de werkhervatting of voorbereidingen daartoe ter sprake te brengen.

Een derde vraag die regeimatig terugkeert is de vraag naar de inschatting die de werknemer heeft ten aanzien van de werkhervatting in de toekomst. Ook als duidelijk is dat iemand zijn werk nog niet kan hervatten, vraagt de verzekeringsarts naar een inschatting. 
va: wat denkt $u$ zelf ten aanzien van het werk? wanneer zou u weer kunnen beginnen? kunt u daar iets over zeggen?

cl: voor de zomer nog niet, gezien m'n kwetsbaarheid kan ik dat nog niet aan. lk weet het niet, maar ik wil het ook liever openhouden, ik ben bang dat de druk anders te groot wordt.

va: heeft $u$ contact met uw collega's?

De vrouw wil nog geen inschatting maken. De verzekeringsarts vraagt ook niet verder. Een precieze datum is niet zo belangrijk. Wat wel belangrijk is, is dat de vrouw nadenkt over een werkhervatting. De vraag zet de vrouw aan om met distantie naar haar eigen situatie te kijken en die in het licht van een toekomstige werkhervatting te analyseren.

Door in de gesprekken structureel vragen in te bouwen ten aanzien van het contact dat werknemers onderhouden met hun werkgever en/of collega's en de toekomstige terugkeer naar het werk, wordt de probleemdefiniëring die in het gesprek centraal staat voortdurend herhaald, zodanig dat werknemers er bijna niet meer omheen kunnen.

\section{Een werknemersprobleem}

De inhoud van de vragen, de volgorde ervan en de antwoorden die er op komen, construeren het probleem dat op de agenda van het gesprek staat. Voor verzekeringsartsen wordt het probleem gedefinieerd door de vraag of iemand zijn of haar werk kan doen. Deze definitic bevindt zich op het terrein van het sociaal functioneren van cliënten. Daarbij gaat het enerzijds om de mate waarin zij hun concrete werkzaamheden al dan niet kunnen uitvoeren, maar ook over de mate waarin zij contacten onderhouden met hun werk, en de mate waarin zij hun netwerk daar in stand houden en over de vraag hoe zij weer terug kunnen keren in hun functie van werknemer. Sommige cliënten schuiven een andere probleemdefinitie naar voren. Het probleem waar het in het gesprek over gaat is de vraag of zij ziek zijn of niet. Daarbij zijn de herkomst van de klachten en de adviezen en de behandeling die zij ondergaan in de curatieve sector belangrijke gegevens. De medisch geformuleerde criteria om vast te stellen of er iets aan de hand is en het netwerk dat ze als patiënt onderhouden treedt dan op de voorgrond.

Welke probleemconstructie in het gesprek centraal staat wordt bepaald gedurende het gesprek. Verzekeringsartsen opteren daarbij voor de werkgebonden definitie en trachten dit perspectief op de agenda te zetten door inhoud en de volgorde van de vragen. Sommige cliënten opteren voor de medische definitie. Gedurende de interactie wordt daarover onderhandeld, waarbij zowel verzekeringsartsen als cliënten volhardend kunnen zijn. Desalniettemin slagen verzekeringsartsen er vaak in om hun probleemdefinitie centraal op de agenda te houden. Verzekeringsartsen proberen werknemers aan hun probleemdefinitie te binden door vragen op een specifieke wijze te introduceren en vast te houden aan dat perspectief. Op werknemers die die agenda niet volgen reageren verzekeringsartsen meteen, door hun vraag in een wat gewijzigde formulering te herhalen, door 'niet-passende' antwoorden te negeren en eventueel hun agenda aan te kondigen. Soms echter 
besteden ze eerst aandacht aan de meer medisch georiënteerde aspecten die cliënten naar voren schuiven om vervolgens de werkgerelateerde probleemdefiniè ring weer op te pakken. Naast de directe reactie op opmerkingen van werknemers, proberen verzekeringsartsen controle over de agenda te houden door de focus, werk en werkhervatting, van het gesprek voortdurend onder de aandacht te houden. Verzekeringsartsen stellen vragen over het werk, over contacten met de werkgever en over een mogelijke werkhervatting in de toekomst, ook als een werkhervatting nog niet direct aan de orde is. Deze vragen maken het echter makkelijker om de werkhervatting ter sprake te brengen als die wel aan de orde is.

De verschillen in probleemdefiniéring hebben verdergaande consequenties dan dat ze alleen de onderwerpen beïnvloeden die besproken worden. Het antwoord op de vraag of er überhaupt sprake is van een probleem en hoe dat er uit ziet wordt er eveneens door beinnvloed. Het is immers heel goed mogelijk om gezondheidsklachten te hebben die concrete werkzaamheden niet beïnvloeden. Door de kwestie in termen van werkhervatting te definiëren schuiven de klachten en het ziek zijn naar de achtergrond. Als de werknemer zijn werknemersrol weer op zich kan nemen, zijn die klachten überhaupt niet meer van belang.

Niet alleen het antwoord op de vraag of er sprake is van een probleem wordt bepaald door de probleemdefinitie. Het vocabulaire waarin gesproken wordt ('kunnen werken' en bijvoorbeeld niet 'ziek zijn') heeft tevens implicaties voor wat er van de interactiepartners wordt verwacht. Arbeidsongeschiktheid wordt door deze probleemdefinitie een sociale kwestie in plaats van een medisch-technische ${ }^{6}$. Door het benadrukken van het werk, de contacten met de werkgever en de toekomstige werkhervatting wordt de cliënt als werknemer aangesproken en niet als zieke. De vragen hebben betrekking op het "werknemer" zijn van de persoon, en niet op zijn rol als zieke of patiènt. Dat bevestigt de actieve houding die van cliënten verwacht wordt. Waar in medisch-technische kwesties de oplossing nog aangedragen kan worden door de arts, die immers de deskundigheid op dat terrein heeft, wordt het bij sociale kwesties moeilijker om de oplossing van het probleem op het bordje van die arts te leggen. In die sociale kwestie wordt het vanzelfsprekender een probleem waar de werknemer zelf iets aan moet doen?

\section{Van praten over, naar doen: het werk hervatten}

". het gaat dus weer wat beter, wanneer denkt $u$ weer te kunnen beginnen?.."

De rolverdeling en de probleemdefini ëring zijn twee mechanismen die gericht zijn op de ordening van het gesprek zelf. In de rolverdeling wordt duidelijk dat de cliẽnten geacht worden competente gesprekspartners te zijn, die een eigen bijdrage leveren aan de doelstelling van het gesprek; in de probleemdefiniëring wordt arbeidsongeschiktheid tot een 
sociale of werkgebonden kwestie gemaakt, waarin zaken die met het werk verbonden zijn besproken worden en waarin cliënten geacht worden hun problemen in termen van het werk te formuleren, zelf hun situatie vanuit dat perspectief te analyseren en na te denken over oplossingen voor die problemen. Zieke werknemers ondergaan de beoordeling niet, maar zijn zelf deelnemer.

Zieke werknemers spelen echter niet alleen een actieve rol binnen het gesprek. Alhoewel in het gesprek alleen gesproken wordt over problemen en oplossingen, impliceren deze gesprekken ook activiteiten die 'buiten' de spreekkamer door de cliënten ondernomen (dienen te) worden. Om van het praten 'over' te komen tot het 'werken' aan een werkhervatting zijn in de gesprekken een aantal elementen aan te wijzen, die de werkhervatting bewerkstelligen. Enerzijds ontwikkelen werknemers plannen ten aanzien van de werkhervatting en anderzijds maken verzekeringsartsen en werknemers afspraken. Verzekeringsartsen vragen werknemers zelf voorstellen te doen, proberen vast te houden aan een stapsgewijze vooruitgang en maken afspraken met werknemers. Deze elementen zal $\mathrm{ik}$ in deze paragraaf bespreken.

\section{Plannen ontwikkelen}

De activering van werknemers valt grofweg uiteen in twee aspecten. De activering is ten eerste gericht op het verhelpen van de klachten. Ten tweede komen het voorbereiden en (geleidelijk) oppakken van de werkzaamheden aan de orde. In beide gevallen wordt de activering besproken aan de hand van de vraag wat de werknemer zelf denkt of doet.

\footnotetext{
va: hoe gaat $\mathrm{u}$ er mee om, wat doet $u$ er aan om beter te worden?

cl: in het begin niks, toen sliep ik alleen maar, nu probeer ik een planning te maken en dingen te doen.

cl: het heeft tijd nodig, ik heb de klap als nog gekregen, de stress moet er nu uit.

va: hoe probeert $u$ er iets aan te doen?

cl: regelmatig te blijven leven, op tijd opstaan, dingen blijven doen, en ik fiets veel.
}

De verzekeringsartsen spreken werknemers direct aan op hun verantwoordelijkheid iets te doen aan hun klachten. Als werknemers zich actief opstellen, dingen doen, en er blijk van geven bezig te zijn met de vraag hoe zij van hun klachten af kunnen komen, volgt een instemmende houding van verzekeringsartsen.

Hetzelfde geldt voor initiatieven die zijn gericht op het oppakken van de werkzaamheden. Eigen voorstellen van werknemers spelen daarbij een belangrijke rol.

\footnotetext{
va: hoeft u enig idee wanneer u weer sou kunnen werken?

cl: nou, ik dacht volgende week maandag.

va: ja, dat zou moeten kunnen als u goed rust houdt. Laten we dat maar proberen.
} 
Zowel in het geval van de behandeling van de klachten als bij de werkhervatting zijn de vragen dusdanig geformuleerd dat de werknemers zelf ideeĕn (moeten) aandragen voor oplossingen.

De vraag naar eigen ideeên van de werknemer ten aanzien van de werkhervatting moet gezien worden in de context van het gesprek en vanuit de probleemdefinié ring die daarin centraal staat. Met enige regelmaat wordt de vraag hoe mensen denken over hun werkhervatting vooraf gegaan door een constatering, die betrekking heeft op de ontwikkeling van de klachten. Is er sprake van een vooruitgang of een verbetering van de klachten, dan wordt het voor werknemers moeilijk om nee te zeggen tegen het oppakken of uitbreiden van de werkzaamheden.

va: maar het gaat toch wel weer wat beter. Kunt u inschatten wanneer u weer kunt beginnen?

cl: geen idee, nu nog niet, misschien over een week of $3-4$.

Als het iets beter gaat met de werknemer wordt het moeilijk om toch te zeggen dat werken nog niet kan. De voortdurende aandacht voor de werkhervatting in de gesprekken, gekoppeld aan het constateren van een verbetering ten aanzien van de klachten die een belemmering voor het werk vormden, maakt het logisch dat bij een verbetering over gegaan kan worden tot het (gedeeltelijk) hervatten van het werk. 'lets beter' betekent 'iets (meer) gaan doen'. De aanpak om het werk geleidelijk op te pakken sluit hier op aan.

Alhoewel verzekeringsartsen beginnen met het vragen naar de 'eigen' ideeën van werknemers, worden die ideeën niet letterlijk overgenomen. Ze vormen wel vaak een aanknopingspunt om plannen verder te ontwikkelen. Verzekeringsartsen doen vaak suggesties, die aansluiten bij de ideeën van werknemers.

va: wat doet u eraan om de problemen op te lossen?

cl: ik ben bij de huisarts geweest, die zegt dat ik eventueel terug kan naar de kliniek, waar ik vroeger met dezelfde problematiek ben geweest. Hij zou daarover bellen. Ik heb vanochtend terug gebeld, maar hij was het vergeten. Ik ben ook naar het RIAGG geweest, maar dat duurt drie weken, dat is te lang. Door het overijiden komen de problemen van vroeger weer terug. Daarom wil ik terug naar dezelfde kliniek, daar kennen ze m'n verleden, maar ik weet niet of dat kan. lk heb het gevoel dat ik toch nog niet alles verwerkt heb.

va: ik denk dat het goed is als $u$ de huisarts nog eens belt, en ook aangeeft dat de problemen met vroeger te maken hebben. Hij moet spoed zetten achter die kliniek.

De werknemer heeft zelf duidelijke ideeën ten aanzien van haar behandeling, maar de uitvoering daarvan duurt volgens haar te lang. De verzekeringsarts doet een suggestie hoe de vrouw daar verandering in aan kan brengen en sluit daarmee aan bij de ideeën van de vrouw zelf. Naar aanleiding van vragen hoe cliënten hun klachten denken te 
verhelpen, geven cliënten regelmatig te kennen dat ze baat zullen hebben bij bepaalde vormen van therapie, zoals bijvoorbeeld fysiotherapie of Mensendieck. Verzekeringsartsen adviseren cliënten dan vaak daar bij de huisarts naar te vragen.

Ook bij het voorbereiden van de terugkeer naar het werk borduren verzekeringsartsen voort op de voorstellen van werknemers. Vaak gebeurt dat in combinatie met het constateren van een verbetering of vooruitgang in het ziekte-herstelproces.

[belanghebbende is gedeeltelijk aan het werk, vindt dat vermoeiend, maar is blij dat ze weer wat doet]

va: we gaan er van uit dat de stijgende lijn doorzet, wanneer kunt u weer volledig hervatten?

cl: ik dacht om het op te bouwen, over twee weken $20 \mathrm{u}$, daarna ga ik twee weken op vakantie en dan kan ik na de vakantie weer helemaal hervatten.

va: het opbouwen is goed, maar over twee weken kunt u wel ietsje meer gaan doen, 25u. Dan kan voor uw vakantie de Ziektewet gestopt worden.

De werknemer doet zelf een voorstel. De verzekeringsarts verandert dat voorstel een beetje, maar zodanig dat de werknemer moeilijk bezwaar kan maken. Het opbouwen is een goed idee van de vrouw, maar het kan wel iets sneller, het gaat immers beter met de vrouw. Door de wijze waarop verzekeringsarts zijn eigen voorstel presenteert als een vertaalslag van het voorstel van de werknemer, lijkt het voorstel niet conflicterend met de gedachten van de werknemer.

Een niet conflicterend voorstel kan tot stand komen door een gedeelte van het voorstel over te nemen, maar ook door het voorstel zodanig in te richten dat aan bezwaren van de werknemer tegemoet kan worden gekomen.

va: ik constateer een lichte vooruitgang, wanneer zou u weer kunnen beginnen?

cl: nog niet, ik ben bang dat ik kinderen laat vallen.

va: een prestatic is op zich wel mogelijk, alleen kunt u niet tillen, kunt u geen andere dingen doen?

cl: ik werk met kinderen die zelf nog niet kunnen lopen, dus ben de hele dag aan het tillen.

va: ik stel voor dat u voor $20 \mathrm{u}$ pw terug gaat, op arbeidstherapeutische basis omdat tillen een belangrijk onderdeel van het werk is. Ik wil u graag over twee weken terug zien, dan kan ik zien hoe het met de schouder gaat en dan kijken we verder of $u$ aan het werk kunt.

De werknemer is van mening dat ze haar werk nog niet kan doen, omdat ze niet kan tillen. De verzekeringsarts gaat akkoord met het niet tillen, maar is tegelijkertijd van mening dat de vrouw wel kan beginnen. Een voorzichtige stap, op basis van de klachten ontwikkeling, maakt dat het niet tot een conflict komt. De verzekeringsarts komt in zijn voorstel tegemoet aan de bezwaren van de vrouw. Ze moet wel naar het werk, maar hoeft niet te tillen. Omdat een groot deel van het werk uit tillen bestaat, gebeurt dit op arbeidstherapeutische basis. Dat betekent dat de vrouw nog wel volledig een beroep doet op de Ziektewet en boventallig aanwezig is. 
Op basis van het voorstel van werknemers zelf, al dan niet in combinatie met het constateren van vooruitgang in de klachtenontwikkeling. lukt het verzekeringsartsen in bovenstaande voorbeelden om werknemers net iets meer te laten doen dan zij zelf voorstelden, zonder dat daar discussie of conflict over ontstaat. Werknemers gaan meteen akkoord, of werpen in ieder geval niets tegen.

In een aantal andere gevallen verloopt de onderhandeling over de activiteiten die werknemers in de toekomst zullen gaan ondernemen veel moeizamer omdat de werknemer wel tegenwerpingen inbrengt. In het volgende voorbeeld slaagt de verzekeringsarts er uiteindelijk in instemming van de werknemer te krijgen voor zijn voorstel.

\section{[belanghebbende heeft haar werk voor $75 \%$ hervat.]}

va: als a terag gaat naar $50 \%$ geeft u or wel aan toe.

cl: maar ik zie het niet zitten $75 \%$, ik ben veel te moe.

va: wat is het verschil met 50\%?

cl: toen ik ging uitbreiden werd het te veel, met halve dagen had ik het gevoel dat ik het beheerste, wat extra komt is te veel, zo'n middag poffertjes bakken of aanwezig zijn op de soos.

va: hoe heeff 4 die $24 u$ dan werdeeld over de week?

cl: oh, maandag heb ik tot $12.30 \mathrm{u}$ gewerkt, dinsdag de hele dag.

va: misschien moet $u$ het gelijkmatiger verdelen, $5 \times 5$ uur gaan werken.

cl: ze hebben me nu weer gevraagd om de soos te doen, maar dat gaat niet

va: die extra uren moet u niet doen.

cl: maar dat is organisatorisch erg ingewikkeld

va: u moet een ritme vinden, een gelijkmatige belasting is onder uw omstandigheden belangrijk, wat u nu doet, iedere dag iets anders is veel te belastend, u moet gewoon weten om $14.00 \mathrm{u}$ ben ik thuis, iedere dag, dat geeft veel meer rust.

cl: misschien komt daar de verwarring wel door.

va: ik vind het zonde om nu terug te vallen.

cl: maar $75 \%$, daar zie ik erg tegen op.

va: ik wil toch dat $u$ het probeert, $75 \%$ en dan gelijkmatig verdeeld. Daar moet u zich dan strikt aan houden, geen extra dingen doen. Bespreekt u dat maar met de werkgever, en dan komt u eind volgende week even terug, dan kijken we of dat beter gaat.

cl: goed, regelmaat is misschien wel beter, ik wil ook wel graag, ik heb genoeg van al dat gedoe, misschien is regelmaat wel de oplossing.

va: ik hoop het.

De vrouw heeft gedeeltelijk haar werk hervat, maar vindt het te zwaar. De verzekeringsarts wil graag dat ze het toch volhoudt. Met wat schipperen over en weer over de werkzaamheden, waarbij de verzekeringsarts met het introduceren van regelmaat probeert zijn voorstel voor de vrouw acceptabel te maken. Een heel snelle heroproep voor het spreekuur lijkt de vrouw toch over de streep te trekken. Het vastleggen van die datum maakt de periode waarover de vrouw de $75 \%$ vast moet houden overzichtelijk, namelijk een week. 
Toch is het niet altijd de verzekeringsarts die de uitslag van de onderhandeling bepaalt. In sommige gevallen wordt overeenstemming bereikt over het voorstel dat door de cliënt naar voren is gebracht.

va: het ziet er goed uit, hoe staat het met het werk? $U$ werkt op arbeidstherapeutische basis op kantoor?

cl: ja, 4 u per dag, telefoon, administratic etc. Dat is beter dan elke dag thuiszitten. Er was echt wel wat te doen.

va: en uw eigen werk als kraamverzorgster?

cl: nou gisteren heb ik een gesprek gehad. Vanaf maandag kan ik het 5 uur proberen.

va: een hele dag is nog te veel?

cl: ja, traplopen is zwaar en ik krijg moede voeten.

va: een hele dag gaat nog niet?

cl: nee, dat is denk ik teveel

va: dan moet u een schema maken, hoe u daarna gaat uitbouwen.

De vrouw heeft op haar werk afgesproken dat ze gedeeltelijk haar eigen werkzaamheden op gaat pakken. De verzekeringsarts vraagt voorzichtig, maar wel tot twee keer toe of de vrouw niet de hele dag haar gewone werk kan oppakken. De vrouw geeft vrij stellig aan dat dat niet gaat, en de verzekeringsarts laat het niet op een conflict aankomen en gaat met het voorstel van de vrouw mee. Wellicht speelt hierbij mee dat de vrouw al afspraken heeft gemaakt met haar werkgever, hetgeen enige garantie geeft dat de vrouw ook werkelijk in haar eigen werk zal gaan hervatten.

In het laatste voorbeeld legt de verzekeringsarts zich neer bij het voorstel van de vrouw en verloopt het gesprek wel soepel. Als cliënten in eerdere fases sterk vast hielden aan een medische probleemdefinitie kunnen voorzichtige voorstellen of suggesties echter ook leiden tot een confrontatie. In feite wordt dan de discussie over de probleemdefiniering weer heropend.

[eerder in het gesprek heeft de verzekeringsarts tegen belanghebbende gezegd dat ze moet leren omgaan met haar klachten, langzaam dingen moet uitproberen. De vrouw reageerde daarop met de uitspraak 'maar als ik geen pijn heb doe ik gewoon alles']

va: u gaat naar de huisarts, vraagt om therapie. U moet proberen op een bepaald functieniveau te komen, leren accepteren dat sommige dingen niet kunnen, proberen om op te bouwen. De spanning doet geen goed.

cl: ja maar met die pijn kun je niet werken.

va: $u$ moet het toch proberen te accepteren.

cl: ja, dat doe je niet.

va: u moet toch proberen om u er bij neer te leggen, dat kan helpen, het is een langzaam proces, probeer het te aanvaarden. Bespreekt u het maar met de huisarts, en laat het even bezinken, dan zie ik u over 4 weken terug. 
In plaats van meer afstand nemen volhardt de vrouw in het naar voren brengen van de pijn, die het haar onmogelijk maakt dingen te doen. Ze wil erkenning voor haar probleem en de aanwijzingen van de verzekeringsarts om te leren accepteren vat ze op als een ontkenning van haar probleem. De voorzichtige voorstellen leiden niet tot overeenstemming, het transformeren van de voorstellen van de werknemer leidt hier tot een confrontatic. De verzekeringsarts slaagt er dan niet in om tot overeenstemming te komen over de activiteiten die de werknemer zal gaan ondernemen.

De werkhervatting is een probleem waarbij de zieke werknemer een verantwoordelijkheid heeft om het op te lossen. Het maken van plannen wordt in eerste instantie bij de werknemer gelegd. Het praten 'over' impliceert tegelijkertijd activiteiten ondernemen. Werknemers moeten doen wat ze zeggen (verzekeringsartsen ook). In de interactic worden de ideeën getransformeerd, maar blijven werknemers er aan gebonden omdat ze ten dele door hen zelf geintroduceerd zijn. Het creëert commitment omdat er een beroep gedaan wordt op het vanzelfsprekende idee dat 'je moet doen wat je zegt', Ook bij het constateren van verbeteringen wordt gebruik gemaakt van een vanzelfsprekend idee van redelijkheid. Eerder in het gesprek is de kwestie waar het over gaat al in werkgebonden termen geformuleerd. De problemen waar werknemers mee kampten waren gelegen in het feit dat ze bepaalde handelingen niet uit konden voeren. Als dat beter gaat is het vanzelfsprekend dat je ook wat meer kunt doen. Omdat de plannen die ontwikkeld worden een soort vanzelfsprekendheid hebben, wordt het moeilijk voor werknemers om zich er aan te onttrekken. Het mensen binden aan wat ze zeggen, wordt versterkt door plannen in afspraken vast te leggen.

\section{Afspraken maken}

Het bespreken van de behandeling van de klachten en de voorbereiding en uitvoering van de werkzaamheden is gericht op overeenstemming over de activiteiten die werknemers in de toekomst zullen gaan ontplooien. De overeenstemming wordt bereikt doordat werknemers zelf voorstellen doen. Aanpassingen die verzekeringsartsen daarin aanbrengen, en die meestal iets verder gaan dan belanghebbenden voorstellen, leiden meestal niet tot conflicten omdat het moeilijk is voor werknemers kleine wijzigingen af te wijzen. Zeker als dat gecombineerd wordt met het vaststellen van vooruitgang. Deze overeenstemming over de activiteiten die werknemers gaan ondernemen wordt vast gelegd in afspraken. Op die afspraken zal in het volgende gesprek worden teruggekomen. Het vastleggen van activiteiten in de vorm van afspraken versterkt de poging tot activering van werknemers. Afspraken zijn immers niet vrijblijvend, maar houden de verplichting in zich om ze na te komen.

Ook bij het maken van afspraken veranderen verzekeringsartsen de voorstellen vaak enigszins. Bijvoorbeeld door niet alleen het voorstel van de werknemer vast te leggen, maar tevens de vervolgstappen. 
va: (doet lichamelijk onderzoek) het is wel verbeterd ten opzichte van de vorige keer, de spieren zijn soepeler, u moet uw oefeningen goed volhouden. Heeft u afspraken gemaakt over uw werk?

cl: ja, ik zou eigenlijk I ochtend meer gaan werken.

va: dat is goed ... dan maken we een opbouwschema. Nu één ochtend meer, over twee weken ook een middag en dan twee weken later volledig hervatten.

Om de lijn in de werkhervatting gaande te houden, worden meteen de vervolgstappen tot een volledige werkhervatting vastgelegd. Meestal levert dat geen problemen, als verzekeringsartsen aansluiten bij de voorstellen van werknemers, dat wil zeggen de voorstellen tegelijkertijd overnemen en veranderen. Het maken van afspraken creëert commitment. Afspraken worden gemaakt in de veronderstelling dat mensen ze nakomen, en omdat er in het vervolggesprek op zal worden teruggekomen, houden ze een verplichting in. Dat het maken van afspraken commitment creëert en verplichtingen inhoudt wordt extra duidelijk als mensen zich niet aan die afspraken houden.

va: ik heb u twee weken geleden gezien... u zou 15 juni gaan eten met het werk, om weer contact op te bouwen.

cl: nou, ik ben niet gegaan.

va: waarom niet?

cl: dat wil ik ook wel, maar het is moeilijk, ik wil het wel.

va: dat zei $u$ vorige keer ook, maar gaat $u$ dan ook eens echt koffiedrinken of zo.

cl: ja, maar dat is moeilijk.

va: ja, de eerste stap is ook moeilijk, maar u moet wel weer terug.

va: dan moeten daar goede afspraken over worden gemaakt, en dan moet u zich daar zelf ook aan houden, dat is voor iedereen beter, en thuis doet u dat ook. Volgende week gaat u op het werk langs om koffie te drinken en dan begint $u$ daama op arbeidstherapeutische basis. Daarover maakt u maar vaste afspraken, met een rooster en als het niet gaat kunt u weg. De week daarna maken wij een afspraak en dan hoor ik hoe het gaat.

De vrouw heeft afspraken gemaakt met de verzekeringsarts, maar is ze niet na gekomen. Op verschillende momenten in het gesprek wordt de vrouw met dit gedrag geconfronteerd: "u zegt het wel, maar doet u het dan ook" en later "maar dan moet u zich daar zelf ook aan houden". Ze wordt aangesproken op het feit dat ze zich niet aan haar afspraken houdt.

\section{Activeren en committeren}

De gesprekken tussen verzekeringsartsen en werknemers zijn gericht op activering van werknemers. Bij die activering beginnen verzekeringsartsen, afhankelijk van de situatie van werknemers, met het verhelpen van de klachten, de voorbereiding van het bespreken van de werkhervatting of het initiëren van de werkhervatting. In eerste instantie wordt 
deze activering bij werknemers zelf gelegd. Door het stellen van vragen over de ideeën van werknemers ten aanzien van het verhelpen van de klachten en/of het voorbereiden van de werkhervatting worden werknemers aangezet om afstandelijk naar zichzelf en hun klachten te kijken en na te denken over de werkhervatting in de toekomst. Werknemers die te weinig initiatief tonen worden daarin gestimuleerd door suggesties of voorstellen van de verzekeringsartsen. Het maken van afspraken, het voortbouwen op de voorstellen van de werknemer, het vasthouden aan een idee van vooruitgang en het aanspreken van de werknemer op z'n verantwoordelijkheid, zowel in het herstelproces, als in de gesprekssituatie zijn hulpmiddelen van verzekeringsartsen om werknemers in de rol van "werknemer met een eigen verantwoordelijkheid om zo spoedig mogelijk weer aan het werk te gaan" te krijgen.

Door het aansluiten bij ideeēn van werknemers en het maken van afspraken worden werknemers gecommitteerd aan de activering, wordt duidelijk dat van werknemers een specifiek type gedrag wordt verwacht. De aanspreekvorm die in de eerste paragraaf is besproken brengt tot uitdrukking dat werknemers betrokken worden in de besluitvorming en een actieve rol hebben in het gesprek. In de wijze waarop verzekeringsartsen de agenda van het gesprek inrichten worden de sociale capaciteiten van werknemers naar voren gehaald, en hun klachten naar achteren geschoven. De mechanismen die commitment moeten bewerkstelligen geven een preciezere richting aan de inhoud van de werknemersrol. Werknemers die deze rol niet als vanzelf op zich nemen wordt dat als het ware geleerd, door ze te stimuleren en, als dat niet voldoende is, aan te spreken op hun (ongepaste) gedragingen.

In de wijze waarop het creëren van commitment vorm krijgt in het gesprek, wordt de verwachting die verzekeringsartsen tot uitdrukking brengen ten aanzien van de rol die werknemers aan behoren te nemen getransformeerd. De mededeling in de introductie dat verzekeringsartsen geïnteresseerd zijn in de oordelen van werknemers zelf, blijkt geen open vraag te zijn. Werknemers worden geacht hun oordeel binnen een bepaald kader te geven. De vraagstelling 'daarbij zijn we geïnteresseerd in uw eigen oordeel' en 'wat denkt u zelf ten aanzien van de werkhervatting?' benadrukken enerzijds de zelfstandigheid van werknemers, werknemers moeten zelf iets doen of vinden. Maar tegelijkertijd is er in het gesprek een impliciete notie aanwezig wat verantwoordelijk gedrag is. Verantwoordelijke werknemers zijn bezig met hun herstel en tonen initiatief. Deze invulling van wat 'verantwoordelijk gedrag' betekent in de spreekkamer van verzekeringsartsen, wordt als het ware mogelijk gemaakt door de probleemdefiniëring die er plaats vindt. Door van de arbeidsongeschiktheid een sociale kwestie te maken, en geen medische, wordt het makkelijker om die eigen verantwoordelijkheid centraal te stellen en krijgt hij tegelijkertijd een specifieke invulling. Meer dan in het medische vertoog past in een sociaal vertoog en actieve opstelling van cliënten. Door in dat sociale vertoog het werk- 
gebonden perspectief te introduceren, worden cliënten aangezet om over hun werknemersrol na te denken en zich als een verantwoordelijke werknemer te gedragen.

Door het creëren van commitment bij werknemers ten aanzien van activiteiten die in de toekomst ondernomen moeten gaan worden, wordt in de interactie een werknemer geconstrueerd, die 'zelfstandig' opereert. De cliënt is geen afhankelijke zieke, maar een sociaal subject: een werknemer die zijn eigen verantwoordelijkheid kent. Die eigen verantwoordelijkheid brengt tegelijkertijd een bepaald type gedragingen met zich mee.

\section{Vertrouwen geven of reguleren ?}

"..prima, regel het maar, we maken een afspraak voor over 5 weken, dan hoor $i k$ wel hoe het gegaan is.."

De gesprekken tussen zieke werknemers en verzekeringsartsen kennen een specifieke ordening waarin specifieke verwachtingen ten aanzien van de rol van de zieke werknemer worden gearticuleerd. Zieke werknemers worden aangesproken als competente gesprekspartners, die zelf een actieve bijdrage moeten leveren in het gesprek. De definiering van arbeidsongeschiktheid als een sociale kwestie, waarin de werkhervatting centraal staat maakt het mogelijk, meer dan een medisch-technische definiëring zou doen, dat werknemers zelf een grote bijdrage leveren aan de oplossing van dat probleem. De wijze waarop plannen geformuleerd worden en afspraken gemaakt, impliceert vrij dwingend een commitment van zieke werknemers aan die plannen en zet aan tot daadwerkelijke acties 'buiten' het gesprek, die uiteindelijk de werkhervatting bewerkstelligen.

Zoals we in de vorige paragraaf hebben gezien worden cliënten door deze ordening aangezet tot het opnemen van hun werknemersrol en de daarbij behorende verantwoordelijkheden zelf te dragen. In een (groot) deel van de gevallen gebeurt dat ook. In andere gevallen heeft het gesprek een ander verloop; cliënten onttrekken zich aan die verantwoordelijkheid. Ze doen bijvoorbeeld een beroep op hun patiëntenrol, komen niet zelf met ideeën of komen hun afspraken niet na. Afhankelijk van die opstelling, verantwoordelijkheid nemen of zich er aan onttrekken, ontstaan andere patronen in het verloop van de gesprekken. Met andere woorden die opstelling heeft consequenties voor de vormgeving van de begeleiding gedurende het traject. In deze paragraaf zal ik die patronen bespreken. Ik begin met werknemers die zich in het gesprek verantwoordelijk tonen.

\section{Verantwoordelijke werknemers}

In de voorafgaande paragrafen is al aan de orde geweest dat verzekeringsartsen in het licht van de werkhervatting initiatieven verwachten van werknemers ten aanzien van de behandeling van hun klachten. Deze initiatieven zijn van belang omdat ze tot uitdrukking brengen dat werknemers bezig zijn met de oplossing van hun problemen en zich daarmee 
opstellen als verantwoordelijke werknemers. Het nadenken en overwegen van mogelijkheden in de toekomst is van belang en wordt door verzekeringsartsen gestimuleerd door instemmend te reageren op reacties van werknemers die deze 'redelijkheid' suggereren.

va: bent $u$ al naar iets anders an het kijken?

cl: ja, er is niet veel. Ik kijk regelmatig in de krant, maar ik denk ook, dan moet ik me wel een beetje goed voelen als ik ga solliciteren, anders wordt het toch niks.

va: daar heeft $u$ wel gelijk in. Rust en een beetje afstand zouden u ook goed doen, maar anderzijds. hoe langer u er uit bent, hoe moeilijker het wordt om er weer tussen te komen.

cl: ja dat weet ik, maar ik kijk ook wel in de krant.

De man komt weliswaar niet tot echte concrete activiteiten, maar maakt duidelijk in zijn overweging dat hij nadenkt of bezig is met een oriëntatie op de toekomst. Het is van belang om verder te kijken, maar solliciteren zou nu wel eens averechts kunnen werken. De verzekeringsarts geeft expliciet aan dat hij het met die overweging eens is.

Eenzelfde soort instemming treedt op bij mensen die initiatief tonen ten aanzien van hun werkhervatting.

va: u heeft voor $50 \%$ hervat, vorige keer ging dat nog niet zo goed, hoe gaat het nu?

cl: Het werken gaat goed, ik heb geregeld dat ik diensten van 6 uur kan draaien. Ik wil nu proberen alle diensten 6 uur te hervatten en dan breid ik daarna uit naar 8 .

va: dat lijkt me goed, als ze op het werk geen problemen hebben met 6 uurs diensten, lijka het me een goede oplossing.

De vrouw heeft in overleg met haar werkgever al een plan gemaakt over hoe ze haar werk verder gaat uitbreiden. De verzekeringsarts geeft aan dat hij dat een goed plan vindt.

Naast bevestiging in het gesprek krijgen werknemers die in de ogen van verzekeringsartsen verantwoord met hun arbeidsongeschiktheid omgaan en/ of initiatief ontplooien vaak ook meer ruimte om hun eigen beslissingen te nemen.

va: hoe is het nu?

cl: niet zo best, ik ben op het werk geweest en wil graag op arbeidstherapeutische basis beginnen. De psycholoog zegt wel dat ik op moet letten. Ik ga een schema maken met m'n baas, zodat ik het langzaam op kan bouwen, ik heb het nog niet geregeld, want $m$ 'n buik is nog niet goed.

va: prima, regel het maar, we maken een afspraak over 5 weken, dan hoor ik hoe het gegaan is.

De vrouw geeft op eigen initiatief aan hoe ze haar werkhervatting denkt vorm te geven. Dat eigen initiatief schept vertrouwen bij de verzekeringsarts. De vrouw is duidelijk bezig met haar hervatting en dat geeft aan dat ze zich niet (alleen) concentreert op haar klachten, maar voldoende afstand heeft. Het vertrouwen van de verzekeringsarts reikt zo 
ver dat hij het niet belangrijk vindt verder over de klachten te praten. Bovendien geeft hij de vrouw vijf weken lang de vrije hand om haar hervattingsproces naar eigen goeddunken in te richten. Ook al zijn de plannen die ze heeft nog geenszins uitgevoerd of vastgelegd, het eigen initiatief dat ze toont is voldoende om met vertrouwen het herstelproces in haar hand te leggen.

Een dergelijke beloning in de vorm van een eigen beslissingsruimte voor werknemers die zelfstandig hun hervattingsplan uitwerken, wordt ook gegeven aan mensen die een concrete hervattingsdatum voorstellen.

[belanghebbende had met de rapporteur afgesproken dat ze haar werk weer zou hervatten, maar dat is niet gelukt. Ze heeft afgelopen vrijdag geprobeerd te lopen, maar dat ging niet. Belanghebbende is verpleegkundige en heeft een gebroken teen.]

va: wanneer denkt u weer te kunnen hervatten?

cl: ja, ik weet het niet, ik hoop volgende week, er staan drie weken voor.

va: we maken een afspraak voor over twee weken, die vervalt als u weer aan het werk bent. We kunnen wel afspreken dat u maandag weer begint, maar als het dan niet lukt, moet $u$ weer helemaal hierheen komen.

$\mathrm{Na}$ afloop zegt de verzekeringsarts: werken met zo'n teen kan niet omdat ze verpleegkundige is. Ik heb haar nog nooit eerder gezien, die gaat wel weer uit zichzelf aan het werk.

De verzekeringsarts heeft er alle vertrouwen in de vrouw voldoende initiatief zal nemen om weer aan het werk te gaan. Dat vertrouwen is gebaseerd op een aantal factoren. $\mathrm{Ze}$ is nog nooit ziek geweest, ze heeft al geprobeerd om te hervatten en dat terwijl het voor de verzekeringsarts vanzelfsprekend is dat haar klachten haar belemmeren in haar werk. Hierdoor ziet de verzekeringsarts dat de vrouw voldoende verantwoordelijkheidsgevoel toont om haar eigen zaakjes te regelen. Ondanks het feit dat ze zelf voorstelt maandag weer te beginnen, krijgt ze van de verzekeringsarts de vrijheid om zelf te kijken wanneer dat weer echt lukt. Ze kan tussen nu en twee weken zelf beslissen wanneer ze haar werk weer hervat zonder dat dat consequenties heeft. De verzekeringsarts acht het niet nodig dat hij daar toezicht op houdt, en om te voorkomen dat de vrouw nodeloos op het spreekuur moet komen, geeft hij haar een marge waarin ze naar eigen oordeel kan handelen".

Het tonen van initiatief en verantwoordelijk gedrag schept tevens ruimte voor verzekeringsarts om de vraag op te werpen of mensen niet te enthousiast zijn.

va: hoe gaan we dat oplossen?

cl: ik weet het niet.

va: ik denk dat $u$ een beetje rust moet nemen.

cl: ja, morgen en vrijdag, dan kan ik maandag wel weer beginnen.

va: is dat niet te snel? Ik wil nu geen definitieve afspraak maken dat u maandag begint. Ik wil u over 1,5 week terug zien, als u eerder beter bent kunt $u$ aan de slag gaan. 
Een beloning kan tenslotte ook bestaan uit het soepel omgaan met de regels, bijvoorbeeld ten aanzien van het opnemen van vakantie of verlengen van de Ziektewet wegens privéomstandigheden. Een werknemer kon bijvoorbeeld eigenlijk wel weer gedeeltelijk hervatten, maar moest ook verhuizen. De hervattingsdatum werd over de verhuizing heen getild, omdat werken en verhuizen een te zware belasting zouden opleveren. De verzekeringsarts geeft na afloop van het gesprek aan dat de vrouw daar eigenlijk vakantie voor zou moeten opnemen, maar dat is ingewikkeld omdat ze slechts gedeeltelijk hervat. De verzekeringsarts legitimeert dit besluit met de woorden 'met deze dame valt ook wel wat te regelen, als het nou een zeurpiet was geweest had ik het anders gedaan'.

Sommige werknemers voegen zich vrij onproblematisch naar de rolverwachting van de verzekeringsartsen, in die zin dat zij hun klachten op een tamelijk afstandelijke manier bespreken en zelf met initiatieven komen om die klachten te verhelpen en/of voorstellen doen om het werk weer op te pakken. Deze werknemers kunnen rekenen op instemming van de verzekeringsartsen. De verzekeringsartsen laten zich in positieve bewoordingen over de werknemer uit, iemand neemt initiatief, is gemotiveerd, doet redelijke voorstellen etc. Deze positieve waardering van de verzekeringsarts komt (ook) tot uitdrukking in de vorm waarin vervolgafspraken worden gemaakt. Deze werknemers krijgen ruimte om naar eigen goeddunken te handelen. Ofwel door geen harde afspraken te maken over de werkhervatting, of door pas na een relatief lange periode een vervolgafspraak te maken (bv. vijf weken) waarbinnen de werknemer naar eigen goeddunken het werk kan oppakken, en/ of plannen uit werken in overleg met de werkgever. Tenslotte schept verantwoordelijk gedrag van werknemers de mogelijkheid om het initiatief van werknemers enigszins af te remmen en in redelijkheid te bespreken of werknemers niet al te enthousiast zijn gezien de klachten die ze hebben.

\section{Afhankelijke zieken}

Lang niet alle werknemers tonen dergelijk initiatief in de gesprekken met verzekeringsartsen. Waar 'verantwoordelijke' werknemers steeds meer ruimte krijgen om het werkhervattingstraject zelf in de hand te nemen, stellen verzekeringsartsen zich bij passieve werknemers eerder directief op.

va: ik heb u drie weken geleden voor het laatst gezien. Als het goed is bent $u$ inmiddels gestart met Mensendieck.

cl: ik heb nog niks van de therapeut gehoord.

va: zoals het er nu uitziet kunt u niet aan de slag. $U$ moet wel vaart zetten achter die Mensendieck

De man had afgesproken dat hij naar therapie zou gaan, maar dat is nog niet gelukt. De verzekeringsarts interpreteert dit als onvoldoende initiatief. In plaats van een bevestiging geeft de verzekeringsarts een vermaning "u moet wel vaart zetten achter die Mensen- 
dieck". Een dergelijke vermaning of terechtwijzing volgt ook op onredelijke verwachtingen van mensen. Een vrouw die niet goed overweg kon met haar collega's reageerde bijvoorbeeld op de vraag 'wat zou u willen' dat een collega die elders een baan had aanvaard terug zou komen. De verzekeringsarts reageerde daarop met 'dat is een utopie, u moet zich niet afhankelijk maken van anderen'. Naast een vermaning uiten verzekeringsartsen soms ook een soort waarschuwing aan werknemers die onvoldoende herstelgedrag, dat wil zeggen activiteiten ondernemen om belemmeringen weg te nemen, tonen.

[belanghebbende zou een gesprek hebben met het maatschappelijk werk, maar die is afgebeld]

va: wat heeft $u$, behalve het maatschappelijk werk, nog meer gedaan om uw situatie te veranderen, want met zo'n gesprek krijgt u geen andere baan.

cl: ja, maar als ik in de krant kijk, voel ik me niet goed, ik wil eerst met het maatschappelijk werk praten. Ik droom ook 's nachts over het werk.

va: ja, maar zo langzamerhand is het geen ziektewetprobleem meer. Ik heb u gemeld aan de GMD, de kans dat u dan nog een uitkering krijgt is niet zo groot. Mijn advies is doe er toch wat aan, hoe langer $u$ eruit bent hoe moeilijker het wordt. Het is niet makkelijk, maar de eerste stap is vaak het moeilijkst. Wij maken een afspraak voor over 3 weken, dan kunt u vertellen hoe het bij het maatschappelijk werk was.

cl: maar ik weet niet of dat dan al geregeld is.

va: nou 3 weken is ruim tijd.

De verzekeringsarts is van mening dat de man te weinig initiatief toont om wat aan zijn klachten te doen. Enerzijds leidt dat tot vermaningen en confrontaties. 'wat doet $u$ nog meer, want met maatschappelijk werk alleen komt u er niet' en 'regel het maar, want het is tijd genoeg'. Anderzijds haalt de verzekeringsarts een formeel argument naar voren, hij verwijst naar de wet: 'zo langzamerhand is het geen ziektewetprobleem meer' en waarschuwt dat de man in de problemen zal komen " de kans dat u nog een uitkering krijgt is niet zo groot."

Dergelijke meningsverschillen tussen verzekeringsartsen en werknemers, waarin de verzekeringsartsen vinden dat de werknemers niet voldoende initiatief tonen treden vaak op bij werklozen. Dat zou te maken kunnen hebben met het feit dat werklozen niet geleidelijk kunnen opbouwen omdat ze geen werk hebben. Het is alles of niets en de mechanismen die commitment creëren werken hier niet, omdat er geen kleine stapjes gemaakt kunnen worden. $\mathrm{Na}$ afloop van een van de gesprekken zegt een verzekeringsarts het volgende:

lastig dat de man geen werk heeft, dan zou je voorzichtig op kunnen bouwen, vanuit WW is het alles of niets. Ik heb het idee dat hij er een beetje gebruik van maakt, hij wekt in ieder geval niet de indruk er echt last van te hebben. Die specialist zegt 3 maanden revalideren, maar dat betekent nog niet niet werken, dat kan soms juist heel goed zijn. 
Opvallend is dat verzekeringsartsen slechts zeer sporadisch sanctionerend optreden, in de zin dat ze de Ziektewet stopzetten ${ }^{10}$. Als ze dat wel doen gebeurt dat meestal meteen in het eerste gesprek en gebruiken verzekeringsartsen formele argumenten: het is geen ziektewetprobleem.

[belanghebbende heeft zich ziek gemeld vanuit de WW en heeft gewerkt als thuishulp. Na een konte introductic en de vraag hoe belanghebbende in de WW terecht is gekomen vraagt de verzekeringsarts wat de reden is van de ziekmelding van de vrouw.]

cl: ik kan maar 0,5 dagen werken door migraine en epilepsie, 's ochtends gaat wel, maar voor meer kan ik niet solliciteren.

va: heeft u elke dag hoofdpijn?

cl: nee, maar ik moet wel opletten, als ik te veel doe, krijg ik last.

va: welke medicijnen krijgt u voor epilepsie? heeft u vaak aanvallen?

cl: dat valt wel mee, als ik regelmatig leef en medicijnen gebruik.

[belanghebbende vertelt dat ze zich op advies van vakbond heeft ziek gemeld]

va: ik zie geen reden voor langdurige arbeidsongeschiktheid.

cl: hoezo?

va: u gebruikt medicijnen, dan kunt u alleen geen onregelmatige diensten draaien, maar verder wel werken. Regelmatige winal is geen neden voor arbeidsongeschiktheid; u zult passend werk moeten zoeken.

......

cl: maar ik vind het werk leuk, en toen ik vast werkte viel ik voortdurend uit, dat is voor een werkgever niet leuk.

va: dat ben ik met u eens, het zal ook niet eenvoudig zijn om iets anders te vinden, maar het is geen reden voor arbeidsongeschiksheid. $\mathrm{U}$ meldt zich maar beter.

De vrouw heeft een aantal klachten die in de ogen van de verzekeringsarts geen belemmering vormen om te werken. De verzekeringsarts stelt zich heel formeel op en geeft aan dat het probleem van de vrouw geen ziektewetprobleem is. Door het inzetten van die formele argumenten creëren verzekeringsartsen een gedepersonificeerd perspectief ${ }^{1 \text { " }}$ " "Ik kan er niets aan doen, de wet schrijft het voor".

Ook als mensen al langere tijd een beroep hebben gedaan op de Ziektewet maken verzekeringsartsen gebruik van formele argumenten als hun inziens de belemmeringen zodanig zijn verbeterd dat de werknemer wel weer kan werken of als mensen onvoldoende initiatief nemen. Vaak verloopt dit wel moeizamer. Wellicht heeft dat te maken met het feit dat verzekeringsartsen gedurende het traject van perspectief veranderen. Waar de inzet aan het begin van het traject gericht was op het bevorderen van de eigen verantwoordelijkheid van de zieke werknemer, waarbij de mening van die werknemer van belang was, neemt die verzekeringsgeneeskundige die verantwoordelijkheid als het ware weer terug en gaat zelf voor de zieke werknemer oordelen ${ }^{12}$. 


\section{Ruimte of afhankelijkheid}

Werknemers die de verantwoordelijke en actieve rol op zich nemen waar de verzekeringsartsen op inzetten, worden vaak bevestigd in hun houding. Het eigen oordeel dat deze werknemers geven getuigt van een verantwoorde en redelijke opstelling. Verzekeringsartsen reageren daar vaak op door werknemers meer ruimte te geven om hun eigen herstelproces vorm te geven. Deze structuur van aanzetten tot activiteit, opnemen van activiteit, belonen en ruimte geven versterkt de rol van de werknemer als goede en zelfstandige werknemer steeds verder. De actieve opstelling van de werknemer creëert steeds meer mogelijkheden om de eigen situatie te kunnen beoordelen en daar naar eigen inzicht op te reageren, omdat deze werknemers blijk geven de 'normen' die gelden ten aanzien van verantwoord werknemersgedrag te hebben geïnternaliseerd.

In gevallen waar werknemers in de ogen van verzekeringsartsen bij het geven van hun eigen oordeel niet de opstelling van een actieve, redelijke en initiatiefrijke werknemer kiezen, werkt de spiraal echter eerder de andere kant uit. Verzekeringsartsen verengen de ruimte die werknemers krijgen door directief aan te geven wat de werknemer moet doen, door af te keuren wat de werknemer voorstelt, door de (suggestie van) openheid in het gesprek te vervangen door de formele taakstelling. Werknemers worden hier steeds passiever gemaakt en onder een controle-regime geplaatst.

\section{Conclusie}

In dit hoofdstuk stond de vraag centraal hoe in de gesprekken tussen verzekeringsartsen en cliënten de constructie van een specifiek type cliënt tot stand komt. In die interactie komt een bepaalde ordening tot stand. In die ordening krijgen cliënten, maar ook verzekeringsartsen, werk en ziekte een bepaalde plaats en daarmee betekenis.

Ten aanzien van de plaats die cliënten in de orde van het gesprek en de arbeidsongeschiktheidsbegeleiding en -beoordeling krijgen is een viertal mechanismen besproken, die elkaar ten dele in chronologische volgorde opvolgen maar tegelijkertijd met elkaar verweven zijn en elkaar versterken. In het dominante patroon in die gesprekken krijgen clienten eerst to horen wat ze moeten doen: zelf oordelen vellen. In de probleemdefinitie die vervolgens geïntroduceerd wordt, en gedurende het hele gesprek steeds herhaald wordt, wordt duidelijk waar dat oordeel over moet gaan. Daarbij wordt arbeidsongeschiktheid als een sociaal probleem gedefinieerd. Door arbeidsongeschiktheid tot een sociale kwestie te definiëren wordt niet alleen het onderwerp waarover gesproken wordt vastgesteld; het heeft tevens implicaties voor de rol van de verzekeringsartsen en de cliënten. Die cliënten zijn vooral werknemer, dat betekent dat over de werkhervatting wordt gesproken, maar ook dat ze de verantwoordelijkheden op zich moeten nemen die horen bij hun werknemersrol: contacten onderhouden met de werkgever en collega's, zelf 
onderhandelen met hun werkgever over de taken die ze wel en niet uit (kunnen) voeren etc. Werknemers die die verantwoordelijkheden nemen krijgen vervolgens ook de vrijheid om die verantwoordelijkheid te kunnen dragen. In de onderhandeling worden elienten getransformeerd tot werknemers en wordt hun positic die van een sociaal subject.

Om cliênten hun eigen verantwoordelijkheid te laten dragen en leiding te laten nemen over hun eigen reīntegratieproces moet veel werk worden verzet. Als ze de spreekkamer binnenkomen zijn ze tegelijkertijd patiēnt en werknemer, en een deel van de cliénten is zelfs voornamelijk patiēnt. De cliënten worden als het ware uit die patiēntenrol gehaald en voortdurend gestimuleerd om vanuit een werknemersperspectief met enige distantie naar zichzelf en hun situatie te kijken. De wijze waarop cliënten worden aangesproken, de continue herhaling van de probleemdefinitie, de aanmoediging om eigen ideeěn te formuleren en activiteiten te ontplooien dragen allemaal bij tot die transformatie van patiēnt tot werknemer.

Het op deze wijze creêren van subjecten is geen expliciete doelstelling van de gesprekken tussen verzekeringsartsen en cliēnten. De aanpak van verzuimcontrole en begeleiding van verzekeringsartsen, die ook in de handleiding voor gesprekken (zie. H2) is terug te vinden, is niet in dergelijke meta-termen geformuleerd. Wel is expliciet aangegeven dat de aanpak van verzuimeontrole en begeleiding gericht moet zijn op de dingen die mensen nog wel kunnen en dat de insteek positief moet zijn. Deze aanpak wordt tegenover een medisch-objectiverende geplaatst. In een medisch-objectiverende aanpak zouden cliënten afhankelijk gemaakt worden, en is er te weinig aandacht voor het persoons- en situatiegebonden karakter van gezondheidsklachten. In de argumentatieve claim beoordeling is daar wel aandacht voor, omdat die methode uitgaat van de wijze waarop cliënten hun eigen klachten benoemen en analyseren. In de analyse van gesprekken tussen verzekeringsartsen en cliënten hebben we gezien dat cliënten er inderdaad toe worden aangezet om hun klachten zelf te benoemen en te analyseren, maar tegelijkertijd is in die analyse het disciplinerende karakter van deze aanpak naar voren gekomen. Deze disciplineringstendens is uitdrukkelijk niet de doelstelling van de gesprekken, maar ligt er wel in besloten. Het meest expliciet wordt dat duidelijk als cliënten die zich het 'medische' vertoog hebben eigen gemaakt, over de ziektegeschiedenis en het behandelingstraject willen spreken. Deze cliënten benoemen en analyseren hun klachten in medische termen, en alhoewel ze dat zelf doen, zoals de bedoeling was, blijkt deze 'zelfanalyse' incorrect. In deze gevallen ontstaat een onderhandeling tussen verzekeringsartsen en cliēnten, die in sommige gevallen gedurende het hele gesprek steeds opnieuw de kop opsteekt. Zoals in de volgende hoofdstukken explicieter aan de orde zal komen, worden deze mensen 'probleemgevallen'. Tegelijkertijd komt op deze momenten de veronderstelde machtsbalans die voort zou vloeien uit de wet, waarin de verzekeringsarts meer macht heeft dan de cliēnt, ter discussie te staan. Er ontstaat immers een patstelling, waarin de verzekeringsartsen meegaan met de claim van cliënten, terwijl zij van mening zijn dat 
die claim onterecht is. Ondanks het feit dat zij de claim onterecht vinden, treden ze niet sanctionerend op. Hun inschatting en verwachting ten aanzien van het verloop van het proces weerhoudt hen daarvan. In deze situaties wordt uiteindelijk de probleemdefinitie van de cliënt doorslaggevend en is de cliënt in dat opzicht dus 'machtiger' dan de verzekeringsarts.

Als twee kanten van dezelfde medaille worden in dit constructieproces, waarin de clienten worden gesubjectiveerd en getransformeerd tot verantwoordelijke werknemers, tevens verzekeringsartsen geconstrueerd. Doordat ze van arbeidsongeschiktheid een sociale kwestie maken, en voortdurend de werkhervatting als centrale probleem op de agenda plaatsen, duiden ze niet alleen wat van werknemers wordt verwacht, maar definieren ze tevens hun eigen identiteit. $\mathrm{Zij}$ zijn mensen (artsen) die oordelen vellen over de vraag of een werknemer zijn of haar werk kan hervatten. In de introductie van de gesprekken met cliënten wordt die taak of identiteit, zij het wellicht impliciet, voortdurend ge(her)definieerd. Het overbrengen van die identiteit aan cliënten speelt een belangrijke rol. In hoeverre zij er in slagen cliënten te transformeren tot werknemers, hangt ten dele af van de mate waarin zij er in slagen hun eigen identiteit aan cliënten te presenteren.

Niet alleen worden cliënten werknemers en krijgt arbeidsongeschiktheid de betekenis van belemmerd zijn in je werk, die ordening geeft ook verzekeringsartsen een specifieke plaats. Waar de aanwezigheid van verzekeringsartsen in deze context gelegitimeerd wordt door hun expertise op het gebied van ziekte, is het juist die ziekte die in deze gesprekken naar de achtergrond wordt geschoven. Dat ziekte naar de achtergrond wordt geschoven hangt samen met de probleemdefinitie die centraal staat. Zoals al is aangestipt geeft die probleemdefinitie het kader waarin over klachten (en ziekte) wordt gesproken, maar betekent dat niet dat de ziekte en de behandeling volstrekt niet aan de orde komen. De positie die ziekte krijgt in de ordening van het gesprek wordt echter niet alleen bepaald door de probleemdefinitie die gericht is op de werkhervatting, maar hangt tevens nauw samen met de wijze waarop behandelend artsen gepositioneerd worden in het gesprek. Die positionering van behandelend artsen en de specifieke wijze waarop zij in de interactie geconstrueerd worden, vormt het onderwerp van het volgende hoofdstuk.

\section{Noten}

1. Deze gespreksfragmenten zijn niet letterlijk, maar gereconstrueerd op basis van aantekeningen. De cursieveringen zijn van de auteur.

2. Vgl. de Swaan's analyse van het intake gesprek in de psychotherapeutische setting. Een van de criteria waaraan cliênten moeten voldoen duidt de Swaan aan met verteller-vertelde: patienten moeten het vermogen bezitten zichzelf te ervaren, waar te nemen, te analyseren en tegelijkertijd over zich zelf te praten; zo'n dubbelperspectief vereist en impliceert een zekere mate van distantie ten aanzien van de eigen problematick.(De Swaan (1990) Het spreekuur als opgave) 
3. De globale inhoud van deze handleiding (De Boer, 1991) heb ik besproken in hoofdstuk 2.

4. Soms zijn of willen mensen geheel of gedeeltelijk weer aan het werk. In het geval van een gedeeltelijke werkhervatting volgt een vergelijkbaar patroon. In het geval van een gehele werkhervatting krijgt het gesprek een andere wending: er wordt dan vrij snel een werkhervattingsafspraak gemaakt. De reden die cliēnten geven voor het feit dat $z e$ nog niet aan het werk zijn is dan meestal dat ze het idee hebben dat ze toestemming aan de verzekeringsarts moeten vragen. Verzekeringsartsen zijn het daar niet mee eens. Alhoewel die toestemming wel nodig is aan het einde van het ziektewetjaar. Dit om te voorkomen dat mensen om strategische redenen (uit de WAO blijven) korte tijd weer gaan werken, maar wel zodanig lang dat de wachttijd voor de WAO opnieuw ingaat.

5. In de gesprekken wordt de 'werkgever' vaak gespecificeerd. Er wordt bijvoorbeeld naar de direct leidinggevende, de personeelsfunctionaris of collega's gevraagd.

6. Door het benadrukken van bepaalde aspecten van de problematick of het aan de orde stellen van specifieke onderwerpen, wordt een bepaald type subject geconstrueerd. Silverman (1989) laat in zijn onderzoek zien dat artsen, afhankelijk van de vraag of zij wel of niet willen opereren, het gesprek in de richting sturen van medisch-technische dan wel sociale aspecten van de patiēnt. Door het benadrukken van de sociale rol van kinderen met een Downsyndroom en een bepaalde hartafwijking slagen artsen erin ouders er van te overtuigen dat niet opereren beter is. Deze besluitvorming wordt voor de hand liggend omdat deze kinderen in sociaal opzicht 'goed' functioneren. Ze zijn vrolijk, gezellig etc. De klachten worden daardoor naar de achtergrond geschoven. Bij kinderen zonder Downsyndroom met dezelfde hartafwijking zijn artsen echter geneigd om al dan niet aan de hand van testuitslagen de medische toestand van het kind te bespreken. Deze kinderen worden geen sociaal subject, maar een medisch object.

7. Vergelijk Mol en van Lieshout (1989): het spreken in termen van problemen, klachten of hulpvragen in de geneeskunde maakt verschil. o.a. omdat de onderlinge relatie tussen arts en patiēnt erdoor wordt gedefinieerd.

8. Vergelijk Rose (1993). In onze samenleving staat autonomie hoog in het vaandel. Autonomie betekent echter niet dat je kunt doen wat je wil. Allerlei instituties zijn er namelijk op gericht mensen te 'Ieren' wat onder autonomie moet worden verstaan, en hoe zij zich als autonome individuen behoren te gedragen.

9. Zie ook Mudde (1995). Mudde spreekt bij dergelijke voorstellen van de verzekeringsarts over een belonend regime. In deze gevallen wordt controle niet nodig geacht.

10. Hier kom ik uitvoeriger op terug in hoofdstuk 4.

11. Dit mechanisme is vergelijkbaar met de autoritaire besluitvorming die Silverman (1989) onderscheidt in zijn analyse van 'gewone' arts-patiënt contacten. Daar doet de arts een beroep op testuitslagen en medische kennis, en stelt die als het ware verantwoordelijk voor het besluit.

12. Deze verandering lijkt op wat Silverman (1989) verandering in besluitvormingsstrategie noemt. De gezamenlijke (democratische) strategie (waar in gesproken wordt in termen van we) wordt ingeruild voor een gedepersonificeerd perspectief (autoritair). Naast wetgeving wordt medische kennis ook op deze manier ingezet. Hier kom ik op terug in hoofdstuk 4 . 



\section{De behandelaar op afstand}

- de constructie van het verzekeringsgeneeskundig domein -

\section{Inleiding}

In de logica van de verzekeringsgeneeskundige praktijk wordt niet alleen een bepaald type cliënt geconstrueerd, maar ook andere betrokkenen krijgen rollen en verantwoordelijkheden toebedeeld. Dit hoofdstuk gaat in op de verhouding tussen behandelend artsen en therapeuten enerzijds en verzekeringsartsen anderzijds. In tegenstelling tot cliênten zijn behandelend artsen en therapeuten niet zelf bij de gesprekken aanwezig. Verzekeringsartsen hebben bij aanvang van de gesprekken met zieke werknemers geen direct contact gehad met behandelend artsen en beschikken ook niet over informatie van behandelend artsen over de ziekte en/of de klachten van de zieke werknemer. Ook later in het begeleidingstraject is er slechts in uitzonderlijke gevallen direct contact tussen verzekeringsartsen en behandelend artsen. Desalniettemin zijn behandelend artsen wel van belang voor de arbeidsongeschiktheidsbegeleiding en - controle. Zieke werknemers gaan over het algemeen ook met hun klachten naar behandelend artsen of therapeuten. In de gesprekken tussen zieke werknemers en verzekeringsartsen komen adviezen van behandelend artsen aan de orde via verhalen van zieke werknemers, meestal in die onderdelen van het gesprek waar de klachten van de zieke werknemers verder worden uitgediept.

Zoals in het vorige hoofdstuk duidelijk is geworden vormen de gezondheidsklachten van zieke werknemers in curatieve zin geen centraal onderwerp van gesprek tussen verzekeringsartsen en zieke werknemers. De probleemdefinitie die in die gesprekken centraal staat wordt immers gevormd door de vraag hoe belemmeringen voor de werkhervatting kunnen worden opgeheven. Met de cliënt als 'zieke' verdwijnt in die definiering ook de curatieve behandeling van de ziekte naar de zijlijn. Tegelijkertijd is in het vorige hoofdstuk aangetoond dat die probleemdefinitie concurreert met een ziektegeorienteerde definitie, waarin cliënten zichzelf juist wel definiëren als patiënten, de curatieve behandeling van hun klachten centraal stellen en behandelend artsen en therapeuten bij wijze van spreken de verzekeringsgeneeskundige spreekkamer binnen halen. De wijze waarop ziekte en arbeidsongeschiktheid gedefinieerd worden in de verzekeringsgeneeskundige praktijk hangt dan ook samen met de definitie van de rol en positie van behandelend artsen en verzekeringsartsen ten opzichte van elkaar en ten opzichte van de cliënt.

In dit hoofdstuk ga ik in op de vraag hoe die verhouding tussen behandelend artsen en verzekeringsartsen in de spreekkamer van de verzekeringsarts tot stand komt. Net als in het vorige hoofdstuk plaats ik daartoe de context in eerste instantie tussen haakjes, niet 
omdat deze geen invloed zou uit oefenen, maar omdat het mij hier gaat om de specifieke betekenis die zij krijgt, om de wijze waarop zij in de interactie wordt gereproduceerd. In de eerste paragraaf komen twee mechanismen aan de orde die in de interactie tussen zieke werknemers en verzekeringsartsen een domeinafbakening construeren tussen behandelend artsen en verzekeringsartsen. Die domeinafbakening komt tot stand door taken te verdelen. Die taakverdeling maakt het mogelijk om de behandeling van gezondheidsklachten enerzijds en de begeleiding naar de werkhervatting anderzijds als onafhankelijke problemen te behandelen. De trajecten die uitgezet worden om deze problemen op te lossen vragen om verschillende typen patiënten/cliënten. Die taakafbakening, probleemdefiniëring en de verwachtingen ten opzichte van het gedrag van de cliënt construeren gezamenlijk de deskundigheden van respectievelijk verzekeringsartsen en behandelend artsen. In de tweede paragraaf zal ik verder uitwerken waarom juist het definiëren van de klachten in termen van belemmeringen voor de werkhervatting in de verzekeringsgeneeskundige praktijk zo'n belangrijke rol speelt, door uitvoeriger in te gaan op situaties waarin een ziekte georiënteerde probleemdefinitie de agenda beheerst. Een ziekte georienteerde probleemdefinitie heeft namelijk consequenties voor de verhouding tussen verzekeringsartsen en behandelend artsen, omdat de scheiding van taken dan problematisch wordt. In de conclusies kom ik terug op de wijze waarop de mechanismen resulteren in de constructie van domeinen van beide hulpverleners en de constructie van de rol of taak van de behandelaar enerzijds en de identiteit van verzekeringsartsen anderzijds.

\section{Ziekte naast werkhervatting}

"..bespreekt u dat met de huisarts, dan kijken wij hoe het met het werk verder moet..."

In het vorige hoofdstuk hebben we gezien dat in de interactie tussen verzekeringsartsen en zieke werknemers een verzekeringsgeneeskundige identiteit wordt gecreëerd. De probleemdefiniëring die in die gesprekken voortdurend herhaald wordt draagt niet alleen bij aan de constructie van de cliënt als zieke werknemer, maar definieert tevens het deskundigheidsdomein van verzekeringsartsen'. Verzekeringsartsen houden zich niet zomaar bezig met ziekte en arbeidsongeschiktheid, ze zijn deskundig ten aanzien van de vraag hoe een werkhervatting gestalte kan krijgen. Die identiteit van verzekeringsartsen komt echter niet alleen tot stand door het (positief) benoemen wat verzekeringsartsen doen. Die definiëring van de identiteit hangt nauw samen met de positionering van verzekeringsartsen ten opzichte van andere betrokkenen. Om een eigen domein te kunnen claimen moet de verhouding tussen de verzekeringsgeneeskundige deskundigheid en de deskundigheid van anderen gedefinieerd worden ${ }^{2}$. In dit geval zijn dat met name behandelend artsen en therapeuten. In deze paragraaf zal ik twee mechanismen bespreken die 
de constructie van domeinen voor respectievelijk verzekeringsartsen en behandelend artsen tot stand brengen.

\section{Scheiding van taken}

In het eerste deel van de analyse van de logica van de verzekeringsgeneeskundige praktijk, zoals die is gepresenteerd in het vorige hoofdstuk, is gebleken dat de medische achtergrond van de klachten van zieke werknemers geen centrale plats inneemt in de gesprekken tussen zieke werknemers en verzekeringsartsen. Vanuit het standaardbeeld over het werk van poortwachters van de arbeidsongeschiktheidsregelingen, waarin cen belangrijk element van hun taak wordt geformuleerd als het nagaan of mensen die een beroep doen op de arbeidsongeschiktheidsregelingen ook echt ziek zijn, is dat merkwaardig. Alhoewel ziekte geen voldoende voorwaarde vormt om tot die regelingen toegelaten te worden is het immers wel een noodzakelijke voorwaarde. Vanuit de probleemdefiniering rondom de werkhervatting die in de gesprekken tussen werknemers en verzekeringsartsen tot stand komt, is het minder vreemd dat de medische achtergrond van klachten niet centraal staat. Toch zal duidelijk zijn dat die medische achtergrond en de behandeling van ziekte (in curatieve zin) in het licht van de arbeidsongeschiktheidsbegeleiding en - beoordeling wel een plaats hebben. In de gesprekken tussen verzekeringsartsen en werknemers komt dit onderwerp dan ook aan de orde. In deze paragraaf ga ik in op de vraag welke plaats de behandeling van klachten heeft en hoe de verzekeringsgeneeskundige deskundigheid zich ertoe verhoudt.

Op de eerste plaats informeren verzekeringsartsen regelmatig naar de behandeling van de klachten, zoals die wordt uitgevoerd door behandelend artsen of therapeuten.

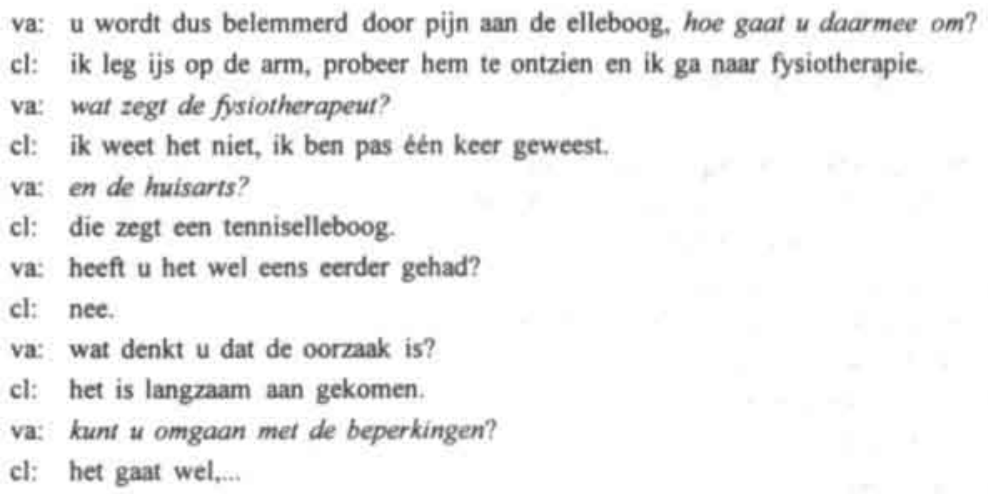

De verzekeringsarts vraagt aan de vrouw wat de huisarts en de fysiotherapeut hebben gezegd over haar klachten. Die vragen worden echter gesteld binnen het kader van de vraag in hoeverre de klachten van de vrouw belemmeringen opleveren voor haar werkzaamheden en wat ze er aan doet om met die beperkingen om te kunnen gaan. Waar de 
vragen van de verzekeringsartsen precies over gaan, of hij geïnteresseerd is in de diagnose, de behandeling, een inschatting van de ernst of de adviezen die de fysiotherapeut of de huisarts hebben gegeven is onhelder en blijft onhelder omdat hij ook niet ingaat op de antwoorden van de vrouw. Meer dan gericht op informatie over wat de huisarts of therapeut nu precies aan de klachten doet, is de verzekeringsarts geïnteresseerd in de wijze waarop de vrouw actief bezig is met het verhelpen van haar klachten. Adviezen van behandelend artsen worden besproken vanuit de vraag wat iemand doet om de belemmeringen op te heffen. Hoe en wat ze precies ondernemen is voor de verzekeringsartsen niet zo van belang.

va: vorige keer was u niet zo tevreden over uw therapeut.

cl: daar heb ik met haar over gesproken, ik wilde naar een psychiater, maar dat vond zij geen goed plan, het geeft een stempel. Ze vindt me niet depressief, maar overwerkt, en die reactie is normaal.

va: het maakt mij ook niet uit bij wie u therapie volgt, als u maar grip krijgt.

cl: ja, ik moet ontspannen. Ik heb steeds geslapen, ik probeer nu wat meer te doen.

De verzekeringsarts toont wel interesse voor de behandeling door terug te komen op het feit dat de vrouw vorige keer niet zo tevreden was over wat de therapeut deed. Zelf spreekt hij daar geen oordeel over uit. Hoe en waar die therapie vorm krijgt maakt niet uit, het gaat om het resultaat. Ten opzichte van de inhoud van de behandeling neemt de verzekeringsarts een neutrale houding aan. Wat er het beste aan de gezondheidsklachten gedaan kan worden laten ze over aan behandelend artsen.

Voor de behandeling van gezondheidsklachten in curatieve zin worden werknemers in de gesprekken tussen werknemers en verzekeringsartsen doorverwezen naar behandelend artsen.

cl: duurt dat altijd zo lang? Ik dacht dat ik er na een paar weken wel klaar mee zou zijn, maar de huisarts heeft het over veel langer.

va: dat ligt eraan, het ligt eraan hoe lang u dingen opgezouten heeft. Nu bent u moe, dan barst het, dingen van jaren terug die naar boven komen, dat heeft tijd nodig, maar u bent al wel verder gekomen, $\mathrm{u}$ heeft al weer dingen opgepakt.

cl: wat ik soms ook had is dat ik niet kon ophouden. Een vlaag van activiteit maar dat moest ik dan later bekopen. Dat doe ik niet meer, ik probeer dat te voorkomen door lijstjes te maken met wat ik moet doen, en doe dan ook niet meer.

va: u heeft moeite met grenzen stellen?

cl: ja, altijd gehad, ik deed alles altijd wel, dat kan nu niet meer, dat is moeilijk.

va: gebruikt u nog medicijnen?

cl: ja ..

va: praat u met de huisarts ook over uself? Weet hij dat u thuis bent?

cl: ja.

va: dat is belangrijk dat hij weet dat dingen so'n druk op u leggen, er is veel gebeurd, u heeft ook al een hoop dingen aangepakt, u moet leren om grenzen te stellen. 
goed, ik denk dat we de uren nog even hetzelfde moeten houden: het programma wordt dan voor $50 \%$ aan de slag, gespreiteen met haisarts en het leren grenzen stellen.

cl: ik hoef nog niet naar een psycholoog?

va: nee, we proberen het eerst 20, u moet wel bij de haisarts ook over wself wrtellen die goff wel aan als hij nodig windt dat u met anderen gaat praten, of als hil het niet movr zelf kan behappen.

De vrouw vraagt aan de verzekeringsarts wat hij vindt van de uitspraak van de huisarts hoe lang het nog gaat duren. De verzekeringsarts houdt zich daarover op de vlakte, maar spreekt tegelijkertijd wel over datgene waar de vrouw tegenaan loopt. De uitspraken van de verzekeringsarts zijn niet helemaal vrij van adviezen hoe de vrouw haar gezondheidsproblemen op kan lossen, maar die adviezen hebben betrekking op de vraag hoe de vrouw haar werk weer kan oppakken. Een voorwaarde voor die werkhervatting is dat ze grenzen kan stellen. De vraag hoe de vrouw behandeld moet worden om er voor te zorgen dat ze grenzen kan stellen, is een kwestie die ze met de huisarts moet bespreken. Zodra de bespreking van de klachten van de vrouw richting de behandeling daarvan gaan, verwijst de verzekeringsarts de vrouw naar de huisarts. Die heeft de verantwoordelijkheid voor het behandelen van de gezondheidsklachten en die beoordeelt of hij dat zelf kan of dat de vrouw naar een psycholoog moet. De behandeling van klachten behoort tot het domein van behandelend artsen of therapeuten.

Ook als verzekeringsartsen het niet eens zijn met een behandeling, laten ze dat over aan de therapeut.

cl: de therapeut vond die band niet goed, dat hoeft helemaal niet. De fysiotherapeut masseert het en zet er een lamp op.

va: misschien kunt u op het werk de band dragen, dat kan ondersteunend zijn, heef u ook rekoefeningen?

cl: ja, die gaan ook veel beter.

va: goed, de tips van de therapeut opvolgen, en dan kunt u maandag weer beginnen..

$\mathrm{Na}$ afloop geeft de verzekeringsarts aan: wat een rare therapie, maar daar bemoei ik me maar niet mee. Dat vinden therapeuten vaak vervelend, en het brengt de verzekerden in verwarring. Als het helpt en de klachten verbeteren dan laat ik het maar.

De verzekeringsarts doet in het gesprek een voorzichtige suggestie aan de vrouw om, ondanks dat de fysiotherapeut dat niet goed vond, toch maar een band te gebruiken op haar werk. Verder laat hij aan de cliênt niet merken dat hij het niet eens is met de behandeling. Die behandeling valt onder de verantwoordelijkheid van de therapeut.

De behandeling of nazorg die een behandelend arts voorschrijft ten behoeve van het verhelpen van gezondheidsklachten, heeft soms consequenties voor de vraag welke belemmeringen werknemers ondervinden bij het uitvoeren van hun werkzaamheden. 
va: heeft $\mathrm{u}$ instructies gekregen van de specialist?

cl: ik mag niet tillen en niet bukken, eigenlijk kan ik niets doen.

va: wat merkt u nog?

cl: ik heb veel pijn in de buik, en na zo'n tripje als dit moet ik languit op de bank. En ik heb last van de ontlasting, ik moet oefeningen doen om het op te houden.

va: u moet oefeningen doen om uw bekken en blaas te trainen, dus dat is er gebeurd, is er verder nog iets?

cl: nee, ik ben blij dat dat het was.

va: nu even het werk, uw werkt op de linnenkamer?

cl: ja, het is till werk, behoorlijk zwaar en ik moet de hele dag staan

va: zit u ook wel eens?

cl: nee, dat kan niet.

va: dus u moet voortdurend staan en lopen, u heeft een zware operatie achter de rug, ik wacht even de controle af. Vraagt $u$ de gynaecoloog dan wel even wat u wel en niet mag, dan kunnen we volgende keer kijken hoe het werk ingevuld moet worden.

De vrouw mag van de specialist niet tillen, maar haar werk bestaat voor een groot deel uit tillen. Het gezondheidsprobleem en het werkprobleem van de vrouw komen als het ware bij elkaar in het 'niet kunnen tillen'. Vanuit het gezondheidsprobleem is het 'niet mogen tillen' een behandelingsadvies van de gynaecoloog. Vanuit het werkhervattingsprobleem is het niet kunnen tillen een belemmering. Die belemmering moet worden opgeheven. Vanuit het gezondheidsprobleem gezien kan dat probleem alleen opgelost worden door de oorzaak weg te nemen. Dat betekent dat de verwondingen van de vrouw moeten genezen, ofwel rust houden. Vanuit het werkhervattingsprobleem kan het probleem echter ook (ten dele) op andere wijze worden opgelost. Door bijvoorbeeld andere werkzaamheden te doen. De behandelend arts mag uitspraken doen ten aanzien van de behandeling van de klachten, in dit geval het niet belasten van de buikspieren. Wat dat betekent voor de werkhervatting is echter een andere kwestie. Die relatie tussen belemmeringen en al of niet werken wordt tot de taak van de verzekeringsarts gerekend. Door taken op deze manier te scheiden, creëren verzekeringsartsen enerzijds taken voor behandelend artsen en therapeuten en anderzijds taken voor zichzelf. De verzekeringsartsen houden zich bezig met problemen ten aanzien van de werkhervatting, behandelend artsen met de behandeling van de gezondheidsklachten.

In die taakafbakening wordt een deel van de taken 'afgestaan' aan behandelend artsen maar kan een ander deel van de taken door de verzekeringsarts geclaimd worden.

va: u heeft mij gebeld omdat u van de verloskundige niet mocht tillen, aan de telefoon hebben we afgesproken dat $\mathrm{u}$ andere dingen zou gaan doen, wat heeft u gedaan op uw werk?

cl: ik heb bedden opgemaakt en medicijnen rondgebracht, dat ging wel, maar al snel ging ik toch weer tillen, dan vraagt iemand om hulp en dan doe je het toch, de collega's denken er de eerste dag nog wel aan maar daarna niet meer. Ik vind het vervelend om dat niet te doen, dat was ook 
toen ik begon met werken op arbeidstherapeutische basis. De gynaecoloog hevft liever dat ik $10 \mathrm{u}$ ga werken.

va: het is nog 3 weken tot uw zwangerschapsverlof. Ik wil toch graag dat a 509 vasthoudt, maar dan echt zonder tillen, dat moet kunnen, want er is genoeg ander werk.

De verloskundige en de gynaecoloog hebben aangegeven dat de vrouw nict mag tillen. Volgens de verzekeringsarts betekent dat echter niet dat de vrouw ook niet kan werken. Door deze kwesties uit elkaar te trekken en als twee problemen te definièren, wordt het mogelijk dat beiden (verzekeringsarts en behandelend arts) een andere taak op zich nemen.

Het actief inzetten van het onderscheid tussen de taken van behandelend artsen en verzekeringsartsen om ten opzichte van werknemers zeggenschap te claimen komt regelmatig voor.

va: u bent een beetje dubbel, aan de ene kant zegt u ik moet niet te hard rennen, rustig opbouwen, maar u geeft zelf ook meteen $200 \%$.

cl: dat klopt, opbouwen zegt psycholoog ook, niet alles tegelijk.

va: maar op zich zijn de uren niet het probleem, maar alles wat er dan op u afkomt.

cl: ik heb op werk overiegd om taken af te stoten naar anderen, dat willen ze wel, maar het loopt niet, de ouders komen toch naar mij toe.

va: wat kunt $u$ daar nou aan doen?

cl: wat ik zeg, meer afschuiven.

va: als $u$ er bent, trekt $u$ alles naar $u$ toe, hoe wil u dat gaan oplossen?

cl: ja, ik maak lijstjes van wat er moet gebeuren en delegeer, daar heb ik met de psycholoog over gesproken, thuis ben ik daar ook mee bezig.

va: even, op de datum en uren komen we zo terug, eerst het echte probleem, alles wat er op u afkomt.

cl: ik maak een planning, maar het is moeilijk om je daar aan te houden met kinderen, ik zeg wel sneller dingen af, sport bijvoorbeeld.

va: maar wat doet u op moment zelf, als mensen beroep op u doen?

va: er zijn twee dingen aan de hand, de uren, dat regelen we hier en wat u in die uren doet, dat heeft $u$ zelf in de hand, daar moet $u$ met psycholoog over praten.

cl: ik wil wel erg graag, maar ik kan niet.

va: wanneer is precies de vakantie? Dan kunt u gedeeltelijke hervatten na de vakantie, 3 ochtenden, dat moet u even met uw werkgever overleggen en goed bespreken met de therapeut, hoe u die uren inricht.

Ook in dit voorbeeld worden twee problemen gedefinieerd: de werkhervatting en het omgaan met gezondheidsklachten. Die problemen vragen om verschillende oplossingen, bij het eerste heeft de verzekeringsarts een taak, bij het tweede de behandelend arts. Verzekeringsartsen perken zo de invloed van behandelend artsen op het werkhervattingstraject in. Behandelend artsen hebben verstand van het oplossen van gezondheidsklachten, maar niet van de vraag welke consequenties gezondheidsklachten hebben voor de 
werkzaamheden die een zieke werknemer al dan niet kan doen. Die taakafbakening heeft twee kanten. Enerzijds worden taken van de behandelend arts benoemd en worden zaken naar de behandelend arts doorverwezen. Daarmee wordt de taak van de behandelaar geconstrueerd. Anderzijds wordt aangegeven wat de behandelend arts juist niet mag doen. Door twee problemen te definiëren krijgen behandelend artsen een duidelijke taak en wordt ruimte gecreëerd om een domein voor de verzekeringsarts te definiëren. Een strijd over wie de juiste adviezen geeft wordt gepacificeerd door de adviezen te definieren als betrekking hebbend op iets anders. De taakafbakening maakt zo een harmonieuze verhouding tussen behandelend artsen en verzekeringsartsen mogelijk.

Zowel behandelend artsen als verzekeringsartsen houden zich bezig met klachten van zieke werknemers. Het verschil in situatiedefinitie maakt echter dat het probleem en de mogelijke oplossingen anders gedefinieerd worden. De behandelend arts houdt zich bezig met de vraag hoe medisch (lichamelijk of geestelijk) gezien de klachten verholpen kunnen worden. De verzekeringsarts houdt zich bezig met de vraag hoe een werkhervatting mogelijk is. Dat verschil in situatiedefinitie creëert andere mogelijke oplossingen en levert daarmee andere taken op voor behandelend artsen en verzekeringsartsen. De taak van behandelend artsen is het opheffen van gezondheidsklachten, dat is hun deskundigheid. De taak van verzekeringsartsen is het bewerkstelligen van een werkhervatting, dat is andere deskundigheid.

\section{Onafhankelijke trajecten}

Het onderscheid tussen behandelend artsen en verzekeringsartsen dat in de gesprekken geconstrueerd wordt, bestaat echter niet alleen uit het verdelen van taken. Via de onderscheiden probleemdefinities worden deze taken tevens op een specifieke wijze aan elkaar gerelateerd. Zieke werknemers komen de verzekeringsgeneeskundige spreekkamer binnen met één probleem: door hun klachten kunnen ze niet werken. De oplossing voor dat probleem lijkt het behandelen van de klachten. Dat zou impliceren dat de taak van de behandelaar vooraf gaat aan de taak van de verzekeringsarts. Gedurende de reeks van gesprekken in de spreekkamer van verzekeringsartsen ontstaan echter geleidelijk twee problemen, die tamelijk onafhankelijk van elkaar opgelost kunnen worden.

\footnotetext{
va: zijn de klachten verminderd als u de hele periode in beschouwing neemt?

cl: sinds zondag gaat het wat beter.

va: heeft $u$ al eens eerder van Cara-achtige klachten last gehad?

cl: nog nooit.

va: de diagnose is dus eigenlijk nog steeds niet duidelijk; heeft u enig idee wanneer $u$ weer met het werk sou kunnen beginnen?

cl: geen idee, het is niks voor mij om zo lang thuis te zitten, maar ik ben uitgeput. Ik slaap slecht en durf ook bijna niet meer te gaan slapen omdat 's nachts de aanvallen zo erg zijn.
} 
va: het verhaal is duidelijk, wat het werk betreft ten minste. Dat kan nog niet. Wij maken over twee weken een nieuwe afspraak, als het eerder beter gaat kunt a eender beginnen. Dan bijvoorbeeld eerst part-time.

In het behandelingstraject zijn de klachten van de vrouw nog niet gediagnosticeerd en worden ze dus ook nog niet behandeld. De klachten leveren nog wel beperkingen op waardoor de vrouw niet kan werken. Maar de onduidelijkheid ten aanzien van de klachten in medische zin laat onverlet dat de werkhervatting besproken wordt. Bovendien maakt de verzekeringsarts duidelijk dat het al of niet bekend zijn van een diagnose, die van belang is voor het medisch oplossen van de gezondheidsklachten, voor de vraag wanneer de werkhervatting plaats kan vinden niet van belang is. Als de vrouw zich beter voelt, ongeacht of duidelijk is wat er medisch aan de hand is, kan de werkhervatting opgepakt worden. In plaats van eerst de diagnose af te wachten, op basis waarvan de gezondheidsklachten behandeld kunnen worden, en dan pas de werkhervatting te bespreken, wordt de vraag of de werkhervatting plaats kan vinden als onafhankelijke vraag op de agenda gezet. De vrouw wordt gevraagd om haar klachten niet medisch, maar vanuit de werkhervatting te bekijken.

Om die werkhervatting als onafhankelijk probleem te kunnen analyseren, moeten zieke werknemers afstand nemen tot datgene wat de behandelend arts zegt of doet. Die afstand kan worden gecreēerd door de werkhervatting als centraal probleem op de agenda te houden, maar ook door directer in te gaan op de vraag hoe zieke werknemers staan tegenover voorstellen van de behandelend artsen.
va: wat is daarvan de aanleiding?
cl: de huisarts zegt de scheiding van 5 jaar geleden.
va: vindt $u$ dat een plausibele verklaring?
cl: ja, hij heeft wel gelijk, maar ik heb er een hekel aan om er wat mee te doen.
va: ...op het werk ligt geen oorzaak?
cl: nee, ik heb 4 kinderen en dat is ook druk. Ik dacht zelf misschien dat het door de drukte kwam, maar misschien is het ook de scheiding.

De zieke werknemer ervaart de klachten en wordt verondersteld zelf ideeën te hebben ten aanzien van het verloop, de oorzaak en de beperkingen die dat met zich meebrengt. Met de vraag naar een oordeel van de belanghebbende over de verklaring van de behandelaar, wordt de belanghebbende gevraagd om zijn klachten en de behandeling daarvan niet alleen te ondergaan, maar daar tevens op een analytische manier naar te kijken', Een eventuele afhankelijke opstelling van de zieke werknemer ten opzichte van de behandelaar wordt hier ter discussie gesteld. De zieke werknemer krijgt een eigen verantwoordelijkheid, waardoor er afstand tussen de werknemer en de behandelend arts wordt 
gecreëerd. Dat zelfde mechanisme treedt op door zieke werknemers op voorhand vragen te stellen over wat zij denken te gaan doen bij de behandelaar.

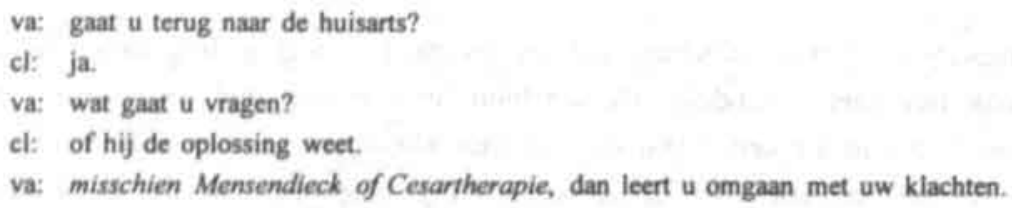

De verzekeringsarts stimuleert de vrouw om zelf na te denken over de behandeling van haar klachten en initiatief te nemen in het behandelingstraject. Als dat initiatief niet vanzelf komt probeert hij door middel van suggesties duidelijk te maken hoe de vrouw dat initiatief vorm kan geven. Daarmee stelt hij impliciet het (mogelijke) idee van de vrouw ter discussie, dat de behandelend arts haar zal zeggen wat ze moet doen en dat zij zelf geen ideeën hoeft te hebben. Door de cliënt aan te zetten tot het nemen van initiatief in de behandeling en het actief zoeken naar adequate hulp wordt een eigen verantwoordelijkheid bij de cliënt gelegd, hetgeen tot uitdrukking brengt dat een eventuele afhankelijke rol van de cliënt in het behandelende circuit, in de spreekkamer van de verzekeringsarts niet op zijn plaats is. Het eigen oordeel van de cliënt staat naast dat van de behandelend arts. Dat wijzen op het belang van een onafhankelijk oordeel van de clienten ten opzichte van behandelend artsen en therapeuten is nodig om cliënten er van te kunnen overtuigen dat de arbeidsongeschiktheid twee problemen omvat, die in twee verschillende circuits opgelost dienen te worden.

Verzekeringsartsen lijken zich in deze voorbeelden te begeven op het terrein van behandelend artsen. De verzekeringsarts stelt immers in het eerste geval de diagnose en in het tweede geval de therapie ter discussie. Tegelijkertijd wordt met het ter discussie stellen duidelijk gemaakt dat het in de spreekkamer van de verzekeringsarts over iets anders gaat dan in de spreekkamer van de huisarts. De uitspraken van de verzekeringsartsen zijn niet zozeer kritiek op de behandelend arts, maar eerder pogingen om de zieke werknemer distantie te laten nemen van het perspectief van de behandelend arts. Die distantie is enerzijds voorwaarde om de werkhervatting als ander probleem te kunnen beschouwen als het behandelen van klachten en anderzijds een 'kenmerk' om het onderscheid tussen een curatieve praktijk en de verzekeringsgeneeskundige praktijk te definieren. Cliënten worden er niet alleen toe aangezet om de problemen die aan de orde zijn in beide praktijken als verschillende problemen te percipiëren, maar tegelijkertijd wordt duidelijk dat cliënten voor het oplossen van die problemen verschillende taken en verantwoordelijkheden moeten dragen. Het met distantie kijken naar de eigen problemen is wellicht bij de behandelend arts geen vereiste, het is wel een vaardigheid waar werknemers over moeten beschikken om in de verzekeringsgeneeskundige praktijk 'goede' cliënten te zijn. 
Door vragen ten aanzien van de werkhervatting op de agenda te plaatsen ongeacht de fase waarin het curatieve traject zich bevindt en door cliênten met distantie te laten kijken naar datgene wat in het curatieve traject gebeurt, wordt de aanzet gegeven om het probleem waar de cliënt de spreekkamer mee binnen kwam in twee problemen te verdelen. Die problemen staan in zeker opzicht los van elkaar, omdat het beantwoorden van de vraag of iemand zijn of haar werk kan hervatten niet per definitie afhankelijk is van de curatieve behandeling van de klachten, die wel de aanleiding voor de ziekmelding vormden. Die problemen worden door respectievelijk verzekeringsartsen en behandelend artsen aangepakt. De behandeling valt daarbij, zoals we hebben gezien onder de bevoegdheid van de behandelend arts. Dat betekent echter niet dat het behandelingstraject in de spreekkamer wordt doodgezwegen. Die behandeling van de klachten is immers iets waar de zieke werknemer eveneens mee bezig is, en ook behandelend artsen en therapeuten vragen commitment en activiteiten van zieke werknemers. Het volstrekt negeren van wat er in het behandelingstraject gebeurt, zou betekenen dat de verzekeringsarts een deel van de cliënt negeert.

De wijze waarop het behandelingstraject een plaats krijgt in de gesprekken tussen werknemers en verzekeringsartsen is overigens opmerkelijk. Verzekeringsartsen volgen via verhalen van de zieke werknemers hoe het behandelingstraject verloopt, maar laten zich in het zoeken naar oplossingen niet volledig leiden door dat traject. Enerzijds wordt aandacht besteed aan het behandelingstraject dat de zieke werknemer ondergaat, anderzijds wordt duidelijk gemaakt dat dat traject niet per definitie bepalend is voor wat er ten aanzien van de werkhervatting wordt ondernomen. Een mogelijke werkhervatting wordt niet alleen ter sprake gebracht, er worden ook activiteiten ondernomen om die werknemers gestalte te geven, ondanks het feit dat er in medische zin niet veel veranderd is.

va: het is wel iets beter geworden. Over vier weken hoort u de uitslag van het neurologisch onderzoek. Mag ik informatie opvragen?

cl: ja.

va: onze afspraken gaan over werk als u niet verder op knapt wachten we het onderzoek af. Als het beter gaat kunt u zelf langzaam het werk oppakken, bijvoorbeeld voor halve dagen.

De vrouw wacht op onderzoeksuitslagen. De verzekeringsarts geeft het behandelingstraject een plaats, maar koppelt de uitslag van de onderzoeken los van de vraag of de vrouw aan het werk kan. Het construeren van twee onafhankelijke problemen, door middel van het op de agenda houden van de werkhervatting en het reflecteren op activiteiten in het behandelingstraject, maakt het mogelijk om op twee fronten tegelijkertijd acties te ondernemen.

va: er zit schot in. $U$ heeft wat tijd nodig om de concentratie op te vijzelen, maar we moeten niet te lang wachten. We wachten wel even af tot $u$ bij de psycholoog bent geweest. We maken een af- 
spraak voor over twee weken. Als $u$ dan daarvoor contact opneemt met de directeur om te horen hoe de situatie op het werk is; en dan hoor ik dan ook wat de psycholoog zegt.

De vrouw gaat naar de psycholoog en het eerste bezoek van de psycholoog wordt afgewacht. Ogenschijnlijk stemt de verzekeringsarts, door die afspraak af te wachten, zijn handelen af op het behandelingstraject. We wachten af wat de psycholoog zegt. Tegelijkertijd moet de vrouw echter overleggen met haar werkgever over de situatie op het werk. Afwachten betekent niet dat de zieke werknemer achterover kan leunen. Tegelijkertijd wordt het traject van de werkhervatting ingezet, ongeacht wat de psycholoog zal zeggen of doen. De vrouw kan terwijl ze wacht op een afspraak met de psycholoog, ook een gesprek met de directeur houden om te kijken hoe de situatie op het werk is. Alhoewel niet te verwachten valt dat er na één gesprek met de psycholoog in medische zin veel veranderd zal zijn ten aanzien van de gezondheidsklachten, is het dan kennelijk wel zinvol om opnieuw over de werkhervatting te spreken. Het afwachten van de afspraak met de psycholoog lijkt dan ook niet zozeer gericht op het verkrijgen van helderheid ten aanzien van de klachten en de prognose, op grond waarvan vervolgens een inschatting ten aanzien van de werkhervatting gemaakt kan worden, als wel gericht op het creëren van rust, waardoor ruimte ontstaat om de werkhervatting opnieuw te bespreken. Het afwachten pacificeert een mogelijke weerstand bij de zieke werknemer om over hun werkhervatting te praten zonder dat er iets aan hun klachten gedaan is.

cl: maar als ik 20 uur niet vol houd?

va: u begint nu gewoon met $50 \%$ en als het lukt werkt u op arbeidstherapeutische basis wat meer, we proberen het uit en volgende keer kijken we of u $100 \%$ kunt hervatten, dan zijn de onderzoeken ook achter de rug.

cl: dat is vlak voor mijn vakantic, kan ik dan wel weg? Maar de uitslagen van het onderzoek zijn dan nog niet bekend.

va: uw vakantic is geen probleem, en de onderzoeken zijn dan afgerond, dan kunnen we wel iets meer zeggen.

Ondanks het feit dat de uitslagen van de onderzoeken die de vrouw ondergaat nog niet bekend zijn op het moment van de vervolgafspraak, en het in medische zin dus nog niet duidelijk zal zijn wat er met de vrouw aan de hand is, is er volgens de verzekeringsarts sprake van een nieuwe situatie als de onderzoeken zijn afgerond. Als de vrouw de onderzoeken achter de rug heeft, is de tijd rijp om het werk verder uit te bereiden, ondanks het feit dat er medisch gezien geen uitsluitsel zal zijn over wat er met de vrouw aan de hand is, is dat er wat betreft de werkhervatting kennelijk wel. Het op deze niet traditioneel medische wijze afstemmen van de twee trajecten op elkaar, geeft ruimte voor de cliënt om afstand te nemen van het idee dat haar klachten eerst behandeld moeten worden, voordat de werkhervatting plaats kan vinden. 
Verzekeringsartsen stemmen hun afspraken met zieke werknemers af op de behandeling die die werknemers ondergaan bij behandelend artsen of therapeuten. Die afstemming is echter niet gericht op de inhoud van de behandeling. Er wordt niet afgewacht tot diagnose en prognose helder zijn, om daar vervolgens de werkhervatting op af te stemmen. Het behandelingstraject wordt tot bepaalde hoogte serieus genomen om vervolgens de werkhervatting als zelfstandig probleem te kunnen bespreken. Het afwachten of afstemmen op de behandeling geeft zieke werknemers tijd om aan het idee wennen dat er twee onafhankelijke problemen aan de orde zijn en neemt tegelijkertijd mogelijke onvrede dat er aan een werkhervatting wordt gewerkt terwijl de klachten nog niet verholpen zijn weg. Het creēert de mogelijkheid op twee afzonderlijke trajecten in gang te zetten.

\section{Twee problemen, twee deskundigheden, twee domeinen}

Het probleem waar de cliënt de spreekkamer binnen komt wordt gedurende de arbeidsongeschiktheidsbeoordeling en -begeleiding gesplitst in twee problemen, die om verschillende oplossingen vragen. Het ene probleem, de behandeling van gezondheidsklachten wordt over gelaten aan behandelend artsen. Dat creëert ruimte om het andere probleem, de werkhervatting tot het zeggenschapsdomein van verzekeringsartsen te laten behoren. Een mogelijke invloed van behandelend artsen op het werk van verzekeringsartsen kan daardoor worden beperkt ${ }^{4}$. Om die scheiding in stand te houden is het nodig om voortdurend 'onderhoudswerkzaamheden' te plegen. Er moet steeds opnieuw benoemd worden welke zaken vallen onder 'werkhervattingsproblemen' en welke zaken vallen onder 'gezondheidsproblemen'. Wat waaronder valt is tot op zekere hoogte onderhandelbaar, mits er tussen verzekeringsartsen en zieke werknemers een (stilzwijgende) overeenstemming bestaat dat de verzekeringsarts verantwoordelijk is voor de werkhervatting, en het probleem dat tijdens die gesprekken op de agenda staat de werkhervatting is. Die overeenstemming komt mede tot stand door het stimuleren van een afstandelijk perspectief ten aanzien van zijn eigen situatie bij de werknemer, hetgeen enige distantie ten opzichte van de behandelaar impliceert. Die distantie geeft op haar beurt weer ruimte om interventies ten aanzien van de werkhervatting onafhankelijk te maken van de uitkomst van het behandelingstraject. De verhouding tussen verzekeringsartsen en behandelend artsen, zoals die in de gesprekken tot stand komt, is harmonieus, ieder heeft een eigen deskundigheidsdomein. Met het deskundigheidsdomein 'behandelen van gezondheidsklachten' worden behandelend artsen en therapeuten tot buitenstaanders ten aanzien van het probleem rondom de werkhervatting.

Waar de constructie van cliënten tot zieke werknemers mede tot stand komt door het creëren van commitment van zieke werknemers zelf, aan de probleemdefiniéring werkhervatting en aan hun rol van werknemer, ligt dat in het geval van behandelend artsen anders. Werknemers worden aan de in het gesprek geconstrueerde rol en verantwoorde- 
lijkheden gebonden door de implicaties die eigen voorstellen en afspraken hebben voor de wijze waarop zij zich gedragen. De constructie van de rol van verantwoordelijkheden van behandelend artsen en therapeuten vindt eveneens in de interactie tussen zieke werknemers en verzekeringsartsen plaats, en niet in een directe onderhandeling tussen verzekeringsartsen en behandelend artsen en therapeuten. In de praktijk is er nauwelijks tot geen contact tussen die beiden, maar vormt de zieke werknemer de schakel tussen hen. Voor een effectieve uitvoering van de arbeidsongeschiktheidsbeoordeling is het voor verzekeringsartsen van belang dat zij een eigen onafhankelijk domein creëren, waarin zij zeggenschap over en autoriteit ten opzichte van de cliënt hebben. De medewerking van de zieke werknemers, en hun erkenning van de specifieke taak van verzekeringsartsen is daarbij van belang. Een erkenning van deze domeinscheiding door behandelend artsen en therapeuten vergemakkelijkt weliswaar hun werk, omdat zieke werknemers dan zowel in de spreekkamer van de verzekeringsarts als in de behandelend arts dezelfde boodschap te horen krijgen, maar is secundair. De beïnvloeding van behandelend artsen ligt echter buiten de directe invloedssfeer van verzekeringsartsen. Meer dan te pogen om behandelend artsen en therapeuten aan hun rol te binden, richten verzekeringsartsen zich dan ook op het committeren van zieke werknemers aan hun opvattingen over de taak- en deskundigheidsverdeling tussen behandelend artsen en henzelf, om die domeinscheiding in de praktijk te effectueren.

\section{Samenvallende domeinen}

"..de specialist zei dat ik me onmiddellijk helemaal ziek moest melden.."

In de gesprekken tussen zieke werknemers en verzekeringsartsen worden taken voor behandelend artsen onderscheiden van taken voor verzekeringsartsen. Door het probleem van zieke werknemers te transformeren in twee problemen, krijgen beide een afzonderlijk deskundigheidsdomein toegewezen. Behandelend artsen gaan over de behandeling van gezondheidsklachten, verzekeringsartsen over de werkhervatting. Door het probleem in de verzekeringsgeneeskundige spreekkamer te definiëren als een probleem ten aanzien van de vraag 'hoe te komen tot een werkhervatting', komt de behandelend arts of therapeut op afstand te staan en creèert de verzekeringsarts een eigen zeggenschapsdomein. Zoals we in hoofdstuk 3 hebben gezien slagen verzekeringsartsen er niet altijd in om de probleemdefinitie rondom de werkhervatting centraal op de agenda te krijgen. In sommige gevallen houden cliënten vast aan een ziekte georiënteerde definitie van hun problemen. In deze gevallen wordt het problematisch voor verzekeringsartsen om de werkhervatting als afzonderlijk probleem te behandelen en zichzelf als een onafhankelijke autoriteit ten opzichte van de zieke werknemer te presenteren. In deze paragraaf zal ik bespreken wat er verschuift in de verhouding tussen verzekeringsartsen en behandelend artsen, 
als een ziekte georiēnteerde probleemdefiniëring centraal komt te staan. In het eerste deel komen situaties aan de orde, waarin verzekeringsartsen zich genoodzaakt voelen zich neer te leggen bij adviezen van behandelend artsen. In het tweede deel situaties waarin ze die adviezen juist gebruiken om de arbeidsongeschiktheid van een zieke werknemer te beëindigen.

\section{Concurrentie tussen artsen}

Het behandelen van de werkhervatting als een onafhankelijk probleem ten opzichte van de behandeling van gezondheidsklachten, dat thuis hoort in de spreekkamer van verzekeringsartsen, staat of valt met de mate waarin verzekeringsartsen er in slagen om die werkhervatting tot centraal onderwerp van de gesprekken met zieke werknemers te maken. Een door de werkhervatting gedomineerde gespreksagenda lijkt de stilzwijgende overeenstemming tussen verzekeringsartsen en zieke werknemers in zich te dragen, dat adviezen en afspraken ten aanzien van de werkhervatting zaken zijn die met de verzekeringsarts geregeld moeten worden. Cliënten respecteren het zeggenschapsdomein van verzekeringsartsen. Bij een gespreksagenda waar een ziekte georiënteerde probleemdefinitie centraal staat lijken cliēnten de domeinscheiding en daarmee het verschil in taken en bevoegdheden tussen behandelend artsen en verzekeringsartsen niet te onderkennen.

va: vorige keer hebben we afgesproken dat u zou uitbreiden van 2 naar 3 ochtenden.

cl: ja, dat heb ik gedaan, maar mu ben ik bij de chiropractor en die zei dat ik onmiddellijk $100 \%$ de Ziektewet in moest. Hij had goede hoop dat het goed zou komen.

cl: de huisarts zei dat ik 3 of 4 keer naar de chiropractor moest, de therapeut vond dat raar; wat de fysiotherapie in $20 \mathrm{x}$ niet lukt moet hij $\mathrm{nu}$ in $3 \mathrm{x}$ doen.

va: ja, maar die therapie werkt heel anders. Wat merkt u van de therapie, helpt het?

cl: eerst werd het erger, nu heb ik alleen nog last van m'n schouder, maar ik heb de laatste tijd ook niks gedaan.

va: hoe lang moet u rust houden?

cl: nou, $u$ kunt informatie opvragen bij de therapeut, maar dat moet dan wel schriftelijk.

va: komt u over een maand maar terug, dan kijken we of rust en warmte op uw vakantic hebben geholpen.

In de nabespreking geeft de verzekeringsarts aan: die chiropractor helpt niet goed, zoveel behandelingen mag helemaal niet. Dit is een heel lastig geval, de vrouw heeft allerlei argumenten waarom ze niet aan het werk wil, maar die belemmering valt volgens mij best mee, $z e$ is heel passief en dat advies $100 \%$ Ziektewet komt haar maar al te goed uit.

De vrouw geeft aan dat ze het advies van de chiropractor om te stoppen met werken heeft opgevolgd en sluit zich aan bij de verontwaardiging van de chiropractor dat deze maar drie keer een behandeling mag geven. De vrouw beroept zich op de autoriteit van de chiropractor en volgt zijn adviezen op. Gedurende het gesprek blijft de verzekerings- 
arts redelijk neutraal, alhoewel hij aangeeft dat de doorverwijzing van de huisarts gezien het karakter van de behandeling van de chiropractor alleszins redelijk is. Hij gaat tevens akkoord met volledige Ziektewet van de vrouw. In de verklaring die hij na afloop geeft blijkt dat hij het eigenlijk niet eens is met dat besluit. Hij is van mening dat de chiropractor ongelijk heeft en de vrouw de chiropractor gebruikt om haar wens om volledig thuis te zitten kracht bij te zetten. De verzekeringsarts legt zich daarbij neer, maar ervaart dat als noodgedwongen. Hij kan niet anders. De vrouw definieert haar probleem als één probleem, namelijk een medisch. Ze gaat er vanuit dat de chiropracter daar zeggenschap over heeft en beschouwt dat niet als een probleem waarin ze zelf verantwoordelijkheid draagt voor de oplossing. De verzekeringsarts is er niet in geslaagd om voor zichzelf een onafhankelijk domein te creëren. Een directe concurrentie met de chiropracter gaat hij uit de weg.

va: $u$ bent 4 weken geleden hier geweest, toen was het niet beter, $\mathrm{U}$ was doorverwezen naar de reumatoloog, en we hebben afgesproken dat we nu zouden kijken hoe dat verlopen is.

cl: ik ben geweest en heb bloed- en urineonderzoek gehad. Er zijn ook röntgenfoto's gemaakt van $m$ 'n hand en de longen.

va: heeft $\mathrm{u}$ al uitslagen?

cl: nee, specialist ging met vakantie.

va: wanneer bent $u$ daar geweest?

cl: 3 weken geleden; de uitslag komt over 3 weken.

va: heeft specialist al iets gezegd over uitslag?

cl: in de hand zit een ontsteking, verder moet hij de uitslag afwachten. Ik heb medicijnen gekregen, die helpen goed tegen de pijn.

....

cl: ik doe bijna niks.

va: is dat advies van de specialist?

cl: nee, ik kan niks, zodra ik wat ga doen komt de pijn en hou ik op.

va: wij wachten uitslag even af; daarna kan ik eventueel informatie opvragen. Wij maken een afspraak voor over 3 weken. (kijkt nog even naar hand) Uw hand is inderdaad dik, maar het ziet er beter uit dan de vorige keer.

na afloop zegt de verzekeringsarts: hier zit ik tegen een muur; ze heeft genoeg gezag achter zich om niet te werken (specialist, huisarts), het gaat beter dus eigenlijk vind ik dat ze het maar weer moet proberen, maar het is vorige keer mislukt, dus eigenlijk heb ik geen ruimte. Die kliniek waar ze behandeld wondt is erg soft, ze schrijven meestal wat de mensen willen, dat maakt het ons erg moeilijk.

Ook in dit fragment is tijdens het gesprek niet veel te merken van de wijze waarop de verzekeringsarts denkt over de behandeling. Uit zijn reactie achteraf blijkt echter dat hij het niet eens is met de arbeidsongeschiktheid. De vrouw geeft geen blijk van erkenning van het bestaan van een onafhankelijk probleem, dat door de verzekeringsarts opgelost zou kunnen worden. Zonder die erkenning, verdwijnt de zeggenschap of autoriteit van de 
verzekeringsarts. De verzekeringsarts ziet het als onmogelijk om zijn eigen koers te varen.

In bovenstaande voorbeelden leggen verzekeringsartsen zich neer bij de adviezen die de behandelend artsen volgens zieke werknemers hebben gegeven. De vraag of los van het verloop van de behandeling een werkhervatting mogelijk is staat niet meer op de agenda. Daarmee verdwijnt het domein van verzekeringsartsen. De verzekeringsarts volgt wat de behandelend arts doet, want het specifieke verzekeringsgeneeskundige onderwerp is van de agenda verdwenen en daarmee is de zeggenschap van verzekeringsgeneeskundige nihil geworden. Verzekeringsartsen lijken geen eigen taak meer te hebben en volgen de adviezen van behandelend artsen op.

Verzekeringsartsen geven twee typen verklaringen voor het feit dat zij zich neerleggen bij arbeidsongeschiktheid, als behandelend artsen of therapeuten dat aangeven, terwijl zij zelf van mening zijn dat zieke werknemers wel weer gedeeltelijk kunnen hervatten. In een van de voorbeelden in de vorige paragraaf gaf de verzekeringsarts aan dat hij zich niet bemoeit met de therapie omdat dat verwarrend is voor de cliënt en omdat therapeuten dat vervelend vinden. Die argumentatie verwijst impliciet naar een specifieke verhouding tussen de verzekeringsarts, de cliēnt en de therapeut, die in andere situaties explicieter benoemd wordt als een vertrouwenskwestie. Zo zegt een van de verzekeringsartsen na afloop van één van de gesprekken:

Adviezen van de fysiotherapeuten zijn vaak discutabel; maar soms interpreteren mensen het ook niet goed; de therapeut zegt dan het gaat zoveel weken duren, en mensen zeggen dan dat ze al die tijd niks mogen doen. Ik voer geen discussie over de therapie, dat is slecht voor het vertrouwen.

Bij geven van tegenstrijdige adviezen door behandelend arts enerzijds en verzekeringsarts anderzijds zou een patiënt gedwongen worden om voor één van beide te kiezen. De verhouding tussen verzekeringsartsen en behandelend artsen zou dan een concurrentie verhouding worden, waarin ze strijden om het vertrouwen van de zieke werknemer. Door de behandeling aan de behandelend arts of therapeut over te laten, ook al lijkt die behandeling in de ogen van de verzekeringsarts niet geschikt, wordt die strijd om het vertrouwen gepacificeerd. Verzekeringsartsen respecteren de domein- en deskundigheidsscheiding tussen hen en behandelend artsen en therapeuten. Als werknemers aangeven dat behandelend artsen adviezen geven ten aanzien van de werkhervatting, en die behandelend artsen het domein van de verzekeringsartsen betreden, wordt het echter moeilijker om die strijd om het vertrouwen te pacificeren, omdat cliënten in deze situaties die domeinscheiding, of eigenlijk de specifieke taak die verzekeringsartsen tot hun domein rekenen, niet lijken te erkennen.

De constructie van de verhouding tussen verzekeringsartsen en behandelend artsen als een potentiële concurrentie-verhouding komt tot stand in de reflectie van verzekeringsart- 
sen op voorgenoemde voorbeelden waarin ze het optreden van de cliënt als een vertrouwensbreuk definiëren. In de ogen van verzekeringsartsen is een vertrouwensbreuk problematisch voor hun werk omdat het advies van de behandelaar een belemmering vormt om een eigen, afwijkend advies te formuleren. Dat dat eigen advies niet meer geformuleerd kan worden hangt samen met het feit dat ze veronderstellen dat cliënten de zijde van de behandelend arts zal kiezen. In die beeldvorming over de situatie worden de verzekeringsartsen als zwakker geconstrueerd.

Een tweede argument dat verzekeringsartsen geven voor het feit dat ze meegaan in een arbeidsongeschiktheidsverklaring, terwijl zij zelf van mening zijn dat iemand wel kan werken, is de inschatting dat ze een beroepszaak zullen verliezen als een zieke werknemer in deze gevallen in beroep gaat tegen een 'arbeidsgeschikt' verklaring.

\footnotetext{
va: hoe gaat het nu?

cl: ik ben geneigd om te denken dat het wel goed gaat, maar klachten nemen toe.

va: welke klachten?

va: we moeten maar $50 \%$ blijven proberen. $U$ bent over 3 maanden uitgeteld, wanneer begint het verlof?

cl: over 7 weken.

va: dan maak ik geen nieuwe afspraak meer, tot dan blijft het $50 \%$ Ziektewet, als het niet meer gaat moet u even bellen. Na het verlof bent u $100 \%$ arbeidsgeschikt, als dat niet gaat moet u zich opnieuw ziek melden.
}

De vrouw belt 's middags terug. Ze is bij de huisarts geweest en mag absoluut niet meer werken. De verzekeringsarts gaat akkoord met volledige Ziektewet.

De verzekeringsarts geeft daarop als reactie: bij zwangerschapsklachten adviezen altijd opvolgen ook al ben je het daar niet mee eens; daar is jurisprudentie over.

Alhoewel de verzekeringsarts in het gesprek met de vrouw tot een afspraak over het gedeeltelijk blijven werken komt, besluit hij na het oordeel van de huisarts dat de vrouw niet meer hoeft te werken. Hij geeft zijn taak over aan de huisarts. In de motivering van dat besluit verwijst hij impliciet naar de mogelijkheid van een beroepszaak. De jurisprudentie in beroepszaken laat zien dat oordelen van behandelend artsen ten aanzien van de werkhervatting bij vrouwen met zwangerschapsklachten oordelen van verzekeringsartsen overrulen. De verzekeringsarts staat zijn taak af. In deze situatie wordt de scheiding van taken doorbroken en tegelijkertijd een andere verhouding tussen behandelend arts en verzekeringsarts geconstrueerd. In plaats van de harmonische verhouding die bij een takkverdeling tot stand komt, verschijnt hier, evenals in situaties die gedefinieerd worden in termen van vertrouwen, een potentiële concurrentie-verhouding. Nog sterker dan in gevallen waarin verzekeringsartsen veronderstellen het vertrouwen van cliënten te verliezen, beschouwen verzekeringsartsen deze strijd bij voorbaat als een verloren strijd. Een 
hiërarchische verhouding tussen behandelend artsen en verzekeringsartsen wordt hier ge(re)produceerd.

\section{Medisch gezien is er niets aan de hand}

Toch betekent een ziekte georiēnteerde probleemdefiniëring en het opgeven van het eigen domein in de gesprekken met cliënten niet altijd dat verzekeringsartsen het nakijken hebben. In een aantal gevallen wordt een keuze gemaakt om van vertoog te veranderen, zodat de verzekeringsarts de greep op de situatie niet verliest. Waar in het werkhervattingsvertoog de eigen verantwoordelijkheid van de patiēnt een belangrijk element is om succesvol tot een reïntegratie te komen, is het binnen het ziekte georiënteerde vertoog niet zozeer van belang wat de zieke werknemer vindt, maar staat er iets anders op het spel. Aan het einde van het vorige hoofdstuk heb ik al laten zien dat verzekeringsartsen in sommige gevallen de Ziektewet beëindigen door een beroep te doen op de formele criteria. Verzekeringsartsen vallen dan terug op een formele definitie van hun taak: het is geen ziektewetprobleem meer. Daarbij doen ze een beroep op medisch-technische informatie. Verzekeringsartsen, zo zou je kunnen zeggen, vechten hier terug met de middelen van de (onwillige) cliënt. Bij cliënten die leunen op uitspraken van behandelend artsen, vervalt als het ware het recht op een eigen oordeel. Als behandelend artsen niets kunnen aantonen, of aangeven dat de klachten minder ernstig zijn dan de cliēnt zegt, kunnen cliënten dus aan het werk, ook al vinden ze zelf hun klachten wel ernstig.

va: ik heb u 3 weken geleden gezien, het ging toen iets beter, 's nachts had u nog veel pijn, $u$ ging naar fysiotherapie, en we hebben afgesproken dat u naar de huisarts zou gaan voor verder onderzoek.

cl: de huisarts heeft bloed afgenomen, er wordt naar van alles gekeken, vrijdag komt de uitslag. afhankelijk daarvan wordt ik doorverwezen, misschien heeft het te maken met de overgang.

va: wanneer krijgt u precies de uitslag?; het zou kunnen dat klachten met elkaar samenhangen.

cl: ik heb pijn aan m'n duim....

va: daar komen we zo op terug, eerst wil ik weten hoe het is met uw rug, gaat het beter dan de vorige keer?

$\mathrm{cl}$ i ik heb nog last bij het stofzuigen, en met traplopen, nu ook bij het naar beneden gaan, dan voel ik m'n knieën, maar die zijn altijd al slecht.

va: en de rug?

cl: ja dat zeg ik, uitstraling in m'n been vanuit de rug.

va: ik weet genoeg, $\mathrm{u}$ bespreekt eind deze week de uitslag van het bloedonderzoek met huisarts en de doorverwijzing voor uw rug, ik zie u over twee weken terug.

$\mathrm{Na}$ afloop van het gesprek geeft de verzekeringsarts aan: die duim noemde ze vorige keer wel, maar niet zo duidelijk. Toen ging het over de rug. Ik wacht uitslag af, als het niets is, is ze arbeidsgeschikt. Het zou wel kunnen dat rug samenhangt met gewrichtsklachten.

De vrouw heeft steeds nieuwe klachten. De verzekeringsarts twijfelt over de vraag of die klachten nu wel echt een belemmering opleveren. De uitslag van het bloedonderzoek 
wordt cruciaal. Als daar niets uitkomt is de vrouw arbeidsgeschikt. Behalve het medisch criterium als maatstaf voor de beoordeling, gelden in dit vertoog ook andere randvoorwaarden waarbinnen een besluit als legitiem wordt gezien. Beslissingen die tegen de wil van belanghebbende in genomen worden, geven een risico dat de cliënten tegen dat besluit in beroep gaan. Er komen dan mogelijk derden in het spel, bijvoorbeeld in een beroepszaak. Verzekeringsartsen anticiperen op de mogelijkheid dat hun oordeel niet getoetst wordt aan de 'informele' interpretatie van de wet als zouden verzekeringsartsen de werkhervatting moeten stimuleren, maar aan het formeel-medische criterium. Het vermoeden van een verzekeringsarts dat de klachten van iemand niet zo ernstig zijn behoeft dan een bevestiging van derden, voordat hij daadwerkelijk zijn besluit neemt.

va: vier weken geieden bent $u$ hier geweest, het ging toen niet $z 0$ goed, maar ik heb toen toch besloten dat u weer kon werken, dat heeft u gedaan, maar 2 weken geleden heeft u zich weer ziek gemeld, met dezelfde klachten?

cl: ja, toen was de arm opeens weer dik, ik ben toen naar het ziekenhuis geweest, daar heb ik een prik gekregen, ik moest rusten, maar het heeft niet geholpen, de arm is nog steeds opgezet en doet pijn, morgen ga ik weer terug naar de specialist.

va: de pijn, is die continu?

cl: ja.

va: wordt $u$ er 's nachts wakker van?

cl: nee.

va: wanneer wordt het erger?

el: het komt opeens opzetten.

va: wat doet $u$ thuis?

cl: niks, dat gaat niet, $m$ 'n vriend doet alles, en soms komt m'n moeder.

va: wat zei de specialist?

cl: niks, die heeft alleen een prik gegeven.

va: (bekijkt de arm) het is duidelijk dik, maar de kracht functic is goed. Ik wil even afwachten wat de specialist zegt, overmorgen zie ik u dan weer terug, u kunt zo meteen een afspraak maken

$\mathrm{Na}$ afloop van het gesprek geeft de verzekeringsarts aan: dat was een hele rare bobbel op de peesaanhechting. ik weet niet wat dat is, de kracht is goed, een erg raar beeld. Ik wil toch even afwachten wat de specialist segt, maar hier speelt zeker ook mee dat de vrouw niet zo gemotiveerd is. Ik denk eigenlijk dat ze wel weer aan het werk kan, het ligt een beetje aan wat de specialist zegt. Dit zou wel eens een beroepsaak kunnen worden, daar laat ik het dan wel op aankomen.

Als de specialist niets ernstigs aantoont, gaat de verzekeringsarts de strijd aan. Het verhaal van de zieke werknemer doet niet meer ter zake. Het wettelijke criterium van medisch-objectieve maatstaven wordt ingezet.

va: (leest de brief die hij op verzoek heeft ontvangen van de neuroloog) de neuroloog kan geen afwijkingen vinden, hij suggereert dat de reumatoloog misschien meer kan vinden, wat zegt u huisarts daarvan? 
va ik kan mijn oonded alleen basenen op medische gegevens, daar komt niets uit, ik heb met uw huisarts overlegt, en de neuroloog gehoord. Er is geen duidelijke medische reden op dit moment: dat betekent dat ik de Ziektewet moet betindigen. Als de medische gegevens veranderen wordt het anders, maar nu is er geen aanleiding om de Ziektewet te continueren.

cl: 20 als ik er tegen aankijk, is dat ik nu niet voor de klas kan staan.

va: dat kan ik me voorstellen, ik snap uw verhaal wel, en ik begrijp dat het niet makkelijk is, maar ik heb geen medische gegevens die hosvast bieden voor de Ziektewet.

va: ik zie geen redenen am $\mathrm{u}$ in de Ziektewet te houden, als $u$ het er niet mee eens bent kunt $u$ in beroep gaan.

Het oordeel van de vrouw is niet meer relevant. De verzekeringsarts stapt over naar een formele aanpak. Hij kan er ook niets aan doen, het is zo in de wet geregeld. De specialisten hebben gezegd dat er niets aan de hand is. De probleemdefinitic van werkhervatting wordt verlaten en vervangen door het probleem 'zijn de klachten echt', Op die vraag verschaft de behandelend arts het antwoord en de verzekeringsarts volgt dat. In plaats van een tegenstander in de concurrentiestrijd om het vertrouwen van de zieke werknemer, wordt de behandelend arts tot bondgenoot van de verzekeringsarts. Tegelijkertijd herdefiniëren verzekeringsartsen hun taak. In plaats van begeleiden naar een werkhervatting, treden ze op als controleur die op objectieve gronden besluiten nemen. Daarmee verliezen ze wel een onafhankelijk zeggenschapsdomein. Hun besluiten vloeien immers voort uit datgene wat behandelend artsen zeggen, en komen niet als onafhankelijke oplossing voor een ander problemen, waar behandelend artsen niets over te zeggen hebben, tot stands.

\section{Medische adviezen, vertrouwen en verantwoordelijkheid}

De identiteit van verzekeringsartsen wordt bepaald door de definitie van hun deskundigheid en de afbakening van het domein. Die deskundigheid wordt inhoudelijk gedefinieerd door het oplossen van problemen ten aanzien van de werkhervatting en methodisch door het aanzetten van zieke werknemers tot het opnemen van een eigen verantwoordelijkheid ten aanzien van het oplossen van belemmeringen ten aanzien van het werk. Deze definitie van deskundigheid construeert een eigen domein ten opzichte van behandelend artsen, die over deskundigheid beschikken ten aanzien van de behandeling van klachten.

In gesprekken tussen werknemers en verzekeringsartsen die gedomineerd worden door een ziekte georiënteerde probleemdefinitie wordt de domeinscheiding tussen verzekeringsartsen en behandelend artsen afgebroken. Omdat de werkgeoriënteerde situatiedefinitie in de gesprekken weg valt, verliezen verzekeringsartsen hun taken. Vaak leggen verzekeringsartsen zich daarbij neer en volgen de adviezen van behandelend artsen of therapeuten. In feite houden ze dan vast aan hun deskundigheid, maar is er geen ruimte om die taken naar behoren uit te kunnen voeren. Om die taken uit te kunnen voeren is 
namelijk commitment van de zieke werknemer nodig, commitment aan de oplossingsstrategie dat deze actief zoekt naar oplossingen om zijn of haar werk weer te kunnen oppakken. In gesprekken waar de ziekte georiënteerde definitie centraal op de agenda staat, hebben zieke werknemers hun eigen positie echter juist als zieke en niet als werknemer gedefinieerd, en zien ze zichzelf op de eerste plaats als patiënt van de behandelende arts. Verzekeringsartsen voelen zich in deze situaties in het nauw gedreven. Waar bij een domeinscheiding tussen verzekeringsartsen en behandelend artsen zieke werknemers tegelijkertijd adviezen van behandelend artsen en verzekeringsartsen kunnen opvolgen omdat die betrekking hebben op verschillende problemen, is in gesprekken waar een ziekte georiënteerde probleemdefinitie op de agenda staat slechts één domein over. De optie om de concurrentie met de behandelend artsen aan te gaan over wie als adviseur van de zieke werknemer kan optreden is bij voorbaat een verloren strijd. Daarmee reproduceren verzekeringsartsen de hiërarchische verhouding binnen de medische beroepsgroep.

Het spreken in termen van strijd met behandelend artsen moet wellicht enigszins genuanceerd worden. De reactie van verzekeringsartsen op het handelen van behandelend artsen, is een reactie op de 'verhalen' van zieke werknemers over behandelend artsen. Verzekeringsartsen geven aan dat die uitspraken van zieke werknemers heel goed af kunnen wijken van wat behandelend artsen hebben (willen) zeggen.

va: je moet er rekening mee houden dat het een interpretatie van iemand is die in een kwetsbare situatie zit. Soms blijkt dan dat zo'n huisarts of fysiotherapeut het veel genuanceerder gezegd heeft dan je in eerste instantie zou denken

Meer dan het voorkomen van een strijd met behandelend artsen, gaan verzekeringsartsen dus de discussie met cliënten, of deze de adviezen van een behandelend arts wel juist interpreteren, uit de weg. Die opstelling lijkt wellicht merkwaardig, omdat navraag bij behandelend artsen de gepercipieerde verschillen tussen de adviezen van behandelend artsen en adviezen van verzekeringsartsen eenvoudig zou kunnen corrigeren. Het is echter maar de vraag of het probleem daarmee opgelost zou zijn. Het probleem waar verzekeringsartsen mee geconfronteerd worden draait niet zozeer om de inhoud van de adviezen, maar is terug te voeren op het gegeven dat de cliënt het onderscheid in taken en zeggenschap tussen behandelend artsen en verzekeringsartsen niet onderkent en bovendien zijn verantwoordelijkheid als werknemer niet op zich neemt. Om hun domein veilig te stellen is het voor verzekeringsartsen van belang dat zieke werknemers de scheiding van domeinen erkennen en zich committeren aan de situatiedefinitie en de taakopdracht binnen de verzekeringsgeneeskundige praktijk. Boven tafel krijgen wat de behandelend arts bedoeld heeft te zeggen, door de kwestie aan de behandelend arts voor te leggen, draagt niet bij aan het bewerkstelligen van dergelijk commitment. Er zijn zelfs 
argumenten aan te voeren op grond waarvan een dergelijke actie juist een averechts effect zou hebben. Zo erkent de verzekeringsarts op dat moment de autoriteit van de behandelend arts en komt zijn onafhankelijkheid in het geding. Bovendien spreekt uit het navraag doen bij de behandelend arts een wantrouwen naar de zieke werknemer toe. Navraag doen is immers alleen maar zinvol als er bij de verzekeringsarts gerede twijfel bestaat dat de zieke werknemer de waarheid niet spreekt. Om een commitment en een interne motivatie bij zieke werknemers te bewerkstelligen om mee te werken binnen de door de verzekeringsarts gedefinieerde probleemstelling, is een dergelijk wantrouwen eerder contra-productief. Het doet expliciet afbreuk aan de oproep van de verzekeringsarts dat het in de gesprekken tussen verzekeringsarts en zieke werknemer gaat om de mening van de zieke werknemer ${ }^{6}$. Dat wil zeggen dat de wijze waarop de zieke werknemer het advies van de behandelend arts gehoord heeft, uitgangspunt van het gesprek is. Of de werknemer volgens de behandelend arts een juiste interpretatie geeft van wat die gezegd heeft of niet, doet niet ter zake. Die interpretatie, of de wijze waarop de werknemer het advies gehoord heef, is op dat moment werkelijkheid voor de werknemer.

Om dezelfde reden is de keuze om op formele gronden een einde te maken aan de arbeidsongeschiktheid voor verzekeringsartsen niet echt cen bevredigende oplossing. Een formele opstelling en het gebruik van medisch objectieve bewijzen van ziekte als hard criterium voor toelating tot de Ziektewet (of eigenlijk het ontbreken van een degelijk bewijs als hard criterium voor uitsluiting) leiden impliciet tot een andere identiteit van verzekeringsartsen, namelijk een identiteit van objectieve controleur. Ze raken dan hun eigen zorgvuldig geconstrueerde domein kwijt en worden afhankelijk van behandelend artsen, want het zijn behandelend artsen die aangeven of er al dan niet sprake is van echte ziekte. Behalve verlies van het inhoudelijke domein, schorten ze daarmee ook hun deskundigheid op als 'stimulator' van de eigen verantwoordelijkheid van de zieke werknemer. Daarmee wordt de werknemer leidend voorwerp, niet alleen van de behandeling van klachten maar ook ten aanzien van de beoordeling. Behandelend artsen worden in deze situaties weliswaar een steun voor de verzekeringsarts, tegelijkertijd worden zowel cliënten als verzekeringsartsen afhankelijk van de behandelend artsen?

\section{Conclusie}

De definiëring van het probleem in de verzekeringsgeneeskundige praktijk als een probleem rondom de werkhervatting van de zieke werknemer speelt niet alleen een rol bij de constructie van cliënten als 'werknemer', maar is tevens van belang voor de constructie van de verhouding tussen behandelend artsen en therapeuten enerzijds en verzekeringsartsen anderzijds. Met behulp van die probleemdefiniëring wordt het mogelijk om een domein voor verzekeringsartsen te onderscheiden van dat van behandelend artsen, 
ondanks het feit dat de positie van beiden haar legitimering vindt in de expertise op het terrein van (het behandelen) van ziekte.

In dit hoofdstuk zijn een tweetal mechanismen besproken, die hun basis vinden in onderscheid tussen een ziekte georiënteerde probleemdefinitie en een werkgeoriënteerde probleemdefinitie, waarmee een domein- en deskundigheidsscheiding tussen behandelend artsen en verzekeringsartsen gestalte krijgt. Die mechanismen 'werken' in op de rol van de cliënt. Die cliënt wordt in de spreekkamer van de verzekeringsarts niet alleen gecommitteerd aan een specifieke probleemdefinièring, zoals we in het vorige hoofdstuk hebben gezien, maar ook aan de taak en het werkterrein van verzekeringsartsen. Dat commitment komt tot stand door middel van het verdelen van taken over behandelend artsen en verzekeringsartsen. Behandelend artsen krijgen daarbij een weliswaar duidelijke maar eveneens afgebakende taak toegewezen. Door de behandelend arts middels die taaktoewijzing een plaats te geven ontstaat ruimte voor verzekeringsartsen om het voor de cliënt aannemelijk en redelijk te maken dat verzekeringsartsen een aantal andere taken kunnen en moeten uitvoeren. Door de taken van behandelend artsen enerzijds en verzekeringsartsen anderzijds te definiëren als oplossingen of behandelingen van verschillende problemen wordt het mogelijk om de begeleiding naar de werkhervatting tot een kwestie te maken die los staat van deskundigheid van behandelend artsen. Behandelend artsen worden zo tot buitenstaanders ten opzichte van het werkhervattingsdomein en verantwoordelijk voor het traject van de behandeling van klachten. Het varen van een onafhankelijke koers in het werkhervattingstraject door het wegschrijven van de invloed van behandelend artsen is een kwestie van geven en nemen (onderhandelen). Het volstrekt negeren van het behandelingstraject, met andere woorden het negeren van het bestaan van de behandelend arts, houdt immers het risico in dat niet alleen de behandelend arts uit het werkhervattingstraject verdwijnt, maar dat deze bovendien de werknemer meeneemt. Niet in lijfelijke zin uiteraard, want de plicht om op het spreekuur van de verzekeringsarts te verschijnen blijft overeind, maar als werknemer. De cliënt wordt dan alleen maar patiënt, terwijl verzekeringsartsen cliënten nodig hebben, die met distantie naar hun eigen situatie kunnen kijken, om op het juiste moment zieke en op het juiste moment werknemer te zijn.

De verhouding tussen behandelend artsen en verzekeringsartsen komt tot stand in de spreekkamer van verzekeringsartsen. Behandelend artsen zijn daar niet aanwezig, de constructie heeft dan ook meer betrekking op de functie die ze vervullen bij de constructie van verzekeringsartsen en werknemers, dan dat het een representatie is van datgene dat behandelend artsen de facto doen in hun eigen spreekkamer. Om de logica van de constructie van verzekeringsartsen en werknemers te begrijpen, is inzicht in de constructie van behandelend artsen echter wel relevant. Verzekeringsartsen hebben specifieke clienten nodig, cliënten die zich gedragen als werknemers, verantwoording dragen voor hun eigen handelen en gericht zijn op activiteiten die een werkhervatting mogelijk maken, om 
hun domein ten opzichte van behandelend artsen veilig te stellen. Cliênten die hun rol als zieke naar voren halen, zijn niet alleen moeilijke cliēnten omdat het ziek zijn een belemmering vormt om aan het werk te gaan, maar ook omdat 'zieken' de verzekeringsgeneeskundige expertise ontkennen. Zieken maken deel uit van de wereld van behandelend artsen en laten de verzekeringsartsen geen ruimte. Dat is problematisch omdat een 'goede' arbeidsongeschiktheidsbegeleiding daarmee onmogelijk wordt. Een goede arbeidsongeschiktheidsbegeleiding bestaat uit het op basis van vertrouwen stimuleren van cliènten om zich als verantwoordelijke werknemers te gedragen. Bij zieken ligt dat problematisch. Houden verzekeringsartsen vast aan hun identiteit, dan staan ze machteloos ten opzichte van zieken, want slagen ze er niet in op deze cliënten om te polen tot werknemers. Het verruilen van die identiteit voor een formele opstelling resulteert weliswaar in een arbeidsgeschikt verklaring en maakt de zieke in die zin noodgedwongen tot werknemer, maar schiet te kort ten aanzien van het bereiken van dat doel op basis van het vertrouwen, en stelt vragen ten aanzien van de mate waarin de werknemer zich gebonden voelt aan het besluit en aan de mate waarin de cliënt de 'verantwoordelijkheid' die bij het werknemersschap hoort opneemt. Externe dwang laat immers geen ruimte voor een internalisering van de controle door zieke werknemers. $\mathrm{Zij}$ gaan werken omdat het moet, niet omdat zij tot het inzicht komen dat dat alleszins redelijk is, dat dat onderdeel vormt van de verantwoordelijkheden die zij dragen omdat zij werknemer zijn. De arbeidsongeschiktheidsbegeleiding op deze wijze beëindigen houdt dan ook een groot risico in voor de vraag hoe lang de werknemer 'werknemer' blijft, ofwel het vergroot het risico op een nieuwe ziekmelding op korte termijn.

Met het vervangen van de patiënt door de werknemer verdwijnt de behandelend arts uit zicht. Behandelend artsen horen immers bij patiënten, niet bij werknemers. En alhoewel verzekeringsartsen er lang niet altijd in slagen de cliënt tot werknemer te construeren, is de positie van behandelend artsen in de logica van de verzekeringsgeneeskundige praktijk er een van buitenstaander. Werknemers horen niet bij behandelend artsen, maar wel bij werkgevers. Op grond van het voorgaande wordt het aannemelijk dat die werkgevers wel een serieuze plaats hebben binnen de logica van de verzekeringsgeneeskundige praktijk. In hoofdstuk drie hebben we al gezien dat werknemers in het kader van de arbeidsongeschiktheidsbegeleiding bijvoorbeeld gestimuleerd worden om contact te onderhouden met hun werkgever en te overleggen over mogelijkheden om hun werk weer op te pakken. Welke plaats werkgevers precies in de logica van de verzekeringsgeneeskundige praktijk innemen en wat 'werkgever' zijn in deze context betekent is het onderwerp van het volgende hoofdstuk. 


\section{Noten}

1. Vergelijk De Swaan (1990), The management of normality, hoofdstuk 6. The initial interview as task. De criteria die psychotherapeuten hanteren tijdens intake gesprekken vervullen een rol bij de selectie van patiënten, maar zij spelen tevens een rol bij het demarkeren van cen competentiedomein van psychotherapeuten ten opzichte van andere hulpverleners.

2. In The system of professions; an essay on the division of expert labour laat Abbott (1988) zien dat de verhouding tussen professionals niet gegeven is met hun formele taakstelling. De scheiding tussen zeggenschapsdomeinen komt in de praktijk tot stand en vormt geen afspiegeling van de formele scheiding. Die formele scheiding en taakdefinitic speelt wel een rol bij de legitimering van werkzaamheden en het bewaken van een deskundigheidsdomein.

3. Vgl. de Swaan (1990), een dubbelperspectief vergt en vereist van de belanghebbende dat hij een zekere mate van distantie kan betrachten ten aanzien van zijn problemen.

Mudde (1995) spreekt in dit verband over een adequate zelfpresentatie (blz. 137)

4. De Wilde (1992) beschrijft pacificeren als een belangrijk element in de demarcatiearbeid van verschillende wetenschappelijke disciplines, met name als een eenmaal verworven positie verdedigd moet worden.

5. Voor de volledigheid is het goed om op te merken dat verzekeringsartsen deze strategie ook niet altijd aantrekkelijk vinden omdat ze op basis van ervaring vinden dat de samenwerking met behandelend artsen en therapeuten nogal te wensen overlaat. Behandelend artsen laten vaak lang op zich wachten en geven informatie waar een verzekeringsarts weinig aan heeft. De volgende uitspraken van verzekeringsartsen illustreren dat: Ik heb het rapport opgevraagd bij de psychiater, maar niets ontvangen. De communicatie

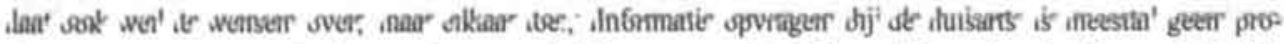
bleem, maar tegenwoordig is er wel een machtiging voor nodig. Bij specialisten kun je alleen schriftelijk informatie opvragen, maar dat duurt vaak lang.; Met de psychiatrische sector loopt dat meestal goed, daarmee kun je ook overleggen over het werk. Met specialisten is dat moeizaam, vaak geven ze geen antwoord op je vragen, maar ze bemoeien zich wel met het werk. Dat ga ik meestal tegen door aan de orde te stellen of de specialist wel weet wat voor werk iemand doet.

6. Dit betekent overigens niet dat verzekeringsartsen nooit navraag doen bij behandelend artsen. In een aantal gevallen geven ze expliciet aan dat in sommige gevallen, juist als er onenigheid bestaat tussen zieke werknemers en henzelf, het oordeel van de behandelend arts door zieke werknemers als legitiem argument geldt om zich bij het besluit van de verzekeringsarts neer te leggen. In het kader van een volgens verzekeringsartsen 'goede arbeidsongeschiktheidsbemiddeling' is deze 'strategie' echter niet erg bevredigend. Zo zegt éen van de verzekeringsartsen naar aanleiding van een gesprek met een cliěnt: ik denk wel dat dat (info opvragen over belastbaarheid, AM) ook van belang is, je probeert hier in de spreekkamer, de acceptatie van je beslissing zo groot mogelijk te maken... het is niet het enige, het zou voor mij niet het enige argument zijn om informatie op te vragen. Het gebeurt wel eens dat ik tegen mensen zeg, nou ik weet voldoende om deze beoordeling te doen. Het is niet niet nodig om informatie op te vragen, dat heeft geen enkele meerwaarde voor mij. maar het kan meespelen voor de acceptatic van de beslissing.

7. Dat 'bondgenootschap' kan in een concreet geval soms effectief zijn. In breder verband maakt dat verzekeringsartsen echter ook kwetsbaar. Discussies binnen de beroepsgroep van artsen laten zien dat juist die identiteit als controleur reden voor behandelend artsen is om verzekeringsartsen een status aparte binnen de beroepsgroep te geven. Juist dat controle aspect van het verzekeringsgeneeskundige werk wordt 
door artsen als smet op het eervolle geneeskundig beroep gezien, waarbinnen de vertrouwensrelatie met patiënten van wezenlijk belang is. 



\section{Werkgevers als spil in de verzuimbegeleiding}

\section{- de constructie van een gezonde arbeidsrelatie -}

\section{Inleiding}

Naast zieke werknemers, verzekeringsartsen en behandelend artsen vormen werkgevers een vierde groep van betrokkenen bij de arbeidsongeschiktheidsbegeleiding en - beoordeling. De constructie van de rol en verantwoordelijkheden van werkgevers staat in dit hoofdstuk centraal. De rol en verantwoordelijkheden die werkgevers krijgen toebedeeld in de arbeidsongeschiktheidsbegeleiding en -beoordeling hangen samen met de in de vorige hoofdstukken besproken onderdelen van de logica van de verzekeringsgeneeskundige praktijk, zowel met de rol en verantwoordelijkheden die andere betrokkenen krijgen toebedeeld als met de specifieke wijze waarop arbeidsongeschiktheid gedefinieerd wordt. In de vorige hoofdstukken hebben we gezien dat arbeidsongeschiktheid gedefinieerd wordt in termen van belemmeringen voor de werkhervatting. Het domein van verzekeringsartsen wordt door die definitie afgebakend en hun deskundigheid bestaat uit het begeleiden van mensen bij het hervatten van hun werkzaamheden, door hen te stimuleren om de verantwoordelijkheid als werknemer op te nemen. Dat deskundigheidsdomein wordt gevormd door een specifieke definitie van het probleem en specifiek type oplossingen, maar ook door een specifiek type cliënten. Cliënten die in deze logica een rol spelen zijn verantwoordelijke subjecten die (bereid zijn) zichzelf in de eerste plaats als werknemer (te) zien, en niet als zieke. Voor verzekeringsgeneeskundige zeggenschap in dat domein is het noodzakelijk dat domein af te bakenen van dat van behandelend artsen en dat cliënten afstand nemen van hun zieken rol en van behandelend artsen. De definiëring van arbeidsongeschiktheid in termen van belemmeringen voor een werkhervatting, het werknemersschap van de cliënt en de deskundigheidsdefinië ring van verzekeringsartsen haalt werkgevers binnen in de logica van de verzekeringsgeneeskundige praktijk. Hun rol en verantwoordelijkheden worden mede bepaald door de logica, maar tegelijkertijd is de roldefinitie van werkgevers medebepalend voor die logica.

In tegenstelling tot behandelend artsen komen werkgevers niet alleen ter sprake in gesprekken tussen werknemers en verzekeringsartsen, maar zijn er ook directe contacten tussen verzekeringsartsen en werkgevers. De belangrijkste vormen van direct contact zijn de Sociaal Medische Teams, die bestaan uit (vertegenwoordigers van) werkgevers, verzekeringsartsen en bedrijfsartsen en gesprekken tussen arbeidsconsulenten ' en werkgevers, die in opdracht van verzekeringsartsen plaats vinden. De rol en verantwoordelijkheden van werkgevers worden op deze verschillende plaatsen geconstrueerd. In dit hoofdstuk 
zal ik dit constructieproces bespreken in het licht van de andere onderdelen van de logica van de verzekeringsgeneeskundige praktijk ${ }^{2}$.

In dit hoofdstuk staan de rol en verantwoordelijkheden van werkgevers centraal. Die rol en verantwoordelijkheden van werkgevers hebben overigens geen betekenis zonder de aanwezigheid van een werknemer. In de gesprekken tussen werknemer en verzekeringsarts en werkgever en verzekeringsarts gaat de bespreking van de rol van de werkgever dan ook vrijwel altijd gepaard met de bespreking van de verhouding tussen werkgever en werknemer. In de eerst paragraaf staat de constructie van de verhouding tussen werkgever en werknemer centraal. Daarbij komt eerst de relatie tussen deze verhouding en de definitie van arbeidsongeschiktheid aan de orde. Vervolgens wordt de verhouding tussen werkgever en werknemer ten opzichte van de verzekeringsgeneeskundige deskundigheid besproken. In de tweede paragraaf wordt het belang van verantwoord werkgeverschap voor de arbeidsongeschiktheidsbegeleiding verder uitgewerkt, door in te gaan op situaties waarin werkgevers zich onttrekken aan hun verantwoordelijkheid. Evenals werknemers belemmeren werkgevers de arbeidsongeschiktheidsbegeleiding als zij toegewezen verantwoordelijkheden niet op zich nemen. Het zich onttrekken aan verantwoordelijkheden heeft dan ook consequenties voor het werk van verzekeringsartsen en de mate waarin werknemers is staat zijn hun werknemersrol vorm te geven. Met een bespreking van deze consequenties wordt het hoofdstuk afgesloten.

\section{De werkhervatting als probleem van de werkgever}

"..ik heb met m'n werkgever afgesproken dat ik volgende week voor halve dagen ga beginnen."

Zowel de definitie van het deskundigheidsdomein van verzekeringsartsen als de plaats van cliënten in de arbeidsongeschiktheidsbegeleiding en -beoordeling impliceren een rol en verantwoordelijkheden voor de werkgever. Werknemerschap heeft geen betekenis zonder werkgever. Met de constructie van werknemers wordt tegelijkertijd een werkgever of beter nog een relatie tussen werkgever-werknemer gedefinieerd. De werknemerwerkgeverrelatie bevindt zich in het hart van het verzekeringsgeneeskundig domein. De constructie van een specifieke werkgeversverantwoordelijkheid en een specifieke werknemer -werkgeverrelatie zijn van belang voor de definitie van arbeidsongeschiktheid en het verloop van de arbeidsongeschiktheidsbegeleiding en -beoordeling en de verzekeringsgeneeskundige identiteit. De constructie van die werkgeversverantwoordelijkheid en de werkgever-werknemerrelatie staan centraal in deze paragraaf. In het eerste deel komt aan de orde hoe die verantwoordelijkheid samenhangt met de definitie van arbeidsongeschiktheid, in het tweede deel staat de relatie tussen verantwoordelijkheden van werkgevers, 
werknemers en verzekeringsartsen en de consequenties die deze verantwoordelijkheidsverdeling heeft voor de arbeidsongeschiktheidsbegeleiding en -beoordeling centraal.

\section{Arbeids(on)geschikt of (on)geschikte arbeid}

Eén van de elementen in het constructieproces van cliènten tot werknemers wordt gevormd door cliênten voortdurend te stimuleren na te denken hoe zij zelf de werkhervatting gestalte kunnen geven. Werknemers worden door middel van vragen over hoe zij de toekomst wat werk betreft zien aangemoedigd om na te denken over hun werk en om met de werkgever te overleggen over die mogelijkheden. Het zijn niet de verzekeringsartsen die bepalen hoe mensen hun werk inrichten, de verantwoordelijkheid voor het zoeken naar oplossingen wordt op het bordje van werknemers gelegd. Werknemers doen dat echter niet alleen, maar in samenspraak met hun werkgevers. De vraag of er sprake is van arbeids(on)geschiktheid wordt daarmee afhankelijk gemaakt van de wijze waarop werknemers en werkgevers gezamenlijk oplossingen definiëren. Die oplossingen hebben op de eerste plaats te maken met de mogelijkheden voor het verrichten van arbeid onder aangepaste omstandigheden.

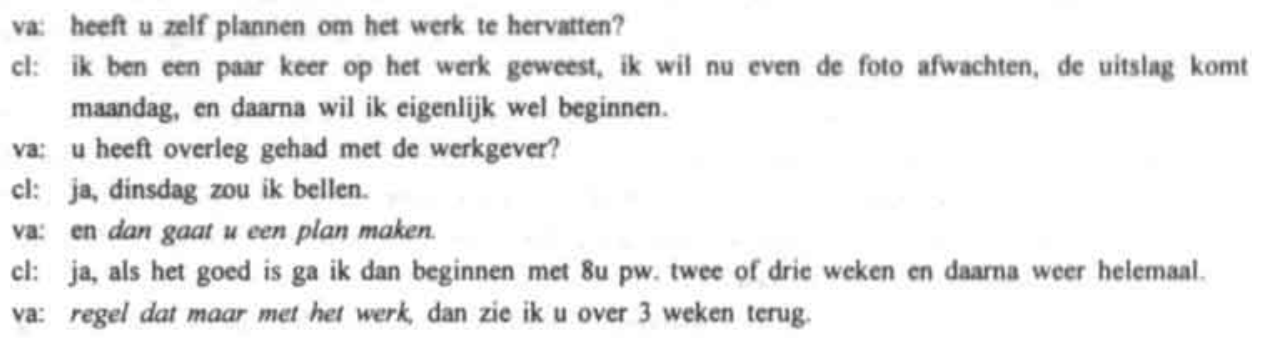

De vrouw heeft een voorstel dat ze met haar werkgever gaat overleggen. De verzekeringsarts geeft aan dat ze die plannen verder met haar werkgever moet bespreken. Werknemers en werkgevers maken onderling afspraken ten aanzien van het precieze aantal uren dat iemand gaat werken en ten aanzien van de taken die de werknemer uit gaat voeren. In feite vormen deze afspraken (indirect) het antwoord op de vraag of iemand arbeidsongeschikt is of niet. Het (gedeeltelijk) hervatten van het werk heeft immers tot consequentie dat iemand praktisch gezien (gedeeltelijk) arbeidsgeschikt wordt. Vaak worden werknemers met een relatief open opdracht naar hun werkgever gestuurd. De afspraken die ze maken worden in het volgende gesprek na besproken.

\footnotetext{
va: u heeft een gesprek gehad met u leidinggevende? Hoe ging dat?

cl: redelijk.

va: viel het mee?

cl: ja, ik heb wel kunnen praten en er werd geluisterd. Ik heb nu afgesproken dat ik volgende week weer ga beginnen voor halve dagen, maar dan nog niet dweilen.
} 
Het overleg tussen werknemer en werkgever gaat in eerste instantie over mogelijkheden om in aangepaste omstandigheden te kunnen werken. Werkgevers wordt gevraagd om mee te werken aan plannen die het mogelijk maken om werknemers gezien hun beperkingen toch zinvol werk te laten doen. Daarvoor wordt van hen flexibiliteit verwacht ten aanzien van het organiseren van de werkzaamheden. Die flexibiliteit heeft invloed op mogelijkheden om belemmeringen voor de werkhervatting op te heffen en kan daarmee de arbeidsongeschiktheid (ten dele) opheffen. Werknemers worden door verzekeringsartsen gestimuleerd om daar met hun werkgevers over te overleggen. Maar ook werkgevers worden door verzekeringsartsen, bijvoorbeeld gedurende het SMT, aangemoedigd om zich actief op te stellen bij het zoeken naar oplossingen.

[Tijdens een Sociaal Medisch Team bij een instelling voor Geestelijke Gezondheidszorg komt een vrouw ter sprake, die daar als maatschappelijk werkster werkt.]

wg: deze vrouw is inmiddels al een behoorlijke tijd uit de roulatic. Er is van alles aan de hand, maar precies weten we het niet. Ik maak me wel zorgen over hoe het moet als ze straks terug komt. $\mathrm{Er}$ is nog al het een en ander aan het veranderen, het zou goed zijn als ze daar wat feeling mee zou houden, anders komt ze straks terug en weet ze niet meer hoe het er hier aan toegaat. Wat zouden we als instelling kunnen doen?

va: deze vrouw heeft aangegeven dat er twee problemen spelen, waardoor ze haar werk niet kan doen. Op de eerste plaats is haar lopen beperkt. Omdat ze immobiel is vindt ze het eng om met cliënten in contact te komen, omdat ze bij onverwachtse agressie of problemen met cliënten niet weg kan. Daarnaast zegt ze dat ze nogal wat tijd nodig heeft om regelmatig de door de fysiotherapeut voorgeschreven oefeningen te doen.

wg: oh, maar met die probleem valt best rekening te houden. Als ze geen baliediensten draait en geen nieuwe cliênten krijgt, komt ze niet in contact met cliënten die zich onvoorspelbaar gedragen.

va: dan lijkt het me goed dat u dat met de vrouw gaat bespreken. Als er mogelijkheden voor haar zijn om het werk op te pakken, moeten die zo snel mogelijk benut worden.

wg: ik denk dat haar afdelingshoofd maar met haar moet gaan praten.

De personeelsfunctionaris heeft een probleem gesignaleerd bij één van zijn zieke medewerkers en vraagt aan de verzekeringsarts wat zij kan doen om de vrouw op z'n minst contact te laten houden met haar werk. De verzekeringsarts geeft geen direct antwoord op de vraag van de personeelsfunctionaris, maar vertelt wat de vrouw zelf heeft gezegd. Daarmee legt hij het beantwoorden van de vraag wat de personeelsfunctionaris kan doen, terug bij de personeelsfunctionaris. Die doet vervolgens zelf voorstellen over hoe een gedeeltelijke werkhervatting vorm kan krijgen en de arbeidsongeschiktheid van de vrouw voor een groot deel opgelost kan worden.

Gedurende het SMT wordt, door het terugleggen van problemen van werknemers, een beroep gedaan op het zelfoplossend vermogen van werkgevers. Dat moet hen leren om 
problemen zelf te herkennen en verantwoordelijkheid te nemen voor het zoeken naar oplossingen voor belemmeringen die werknemers ondervinden.

[Tijdens het SMT vertelt een werkgever naar aanleiding van de bespreking van de verzuimeijfers van het afgelopen half jaar het volgende:]

wg: Met mevrouw $x$ hebben we een uitvoerig gesprek gevoerd omdat ze na haar awangerschap veelvuldig verzuimde. Ze woont op vrij grote afstand van haar werk en haar dochtertje ging naar de crèche in haar woonplaats. Uit het gesprek bleek dat ze met name op vrijdagmiddag regelmatig in de problemen kwam. Op die tijd komen er vaak crisissituaties voor. Veel andere opvanginstellingen zijn dan al gesloten, daarom komen mensen bij ons terecht. Maar op vrijdagmiddag is het tevens moeilijk en tijdrovend om nog voor het weekend wat te regelen, omdat veel andere instellingen al gesloten zijn. Mevrouw $\mathrm{x}$ werkte vaak op vrijdagmiddag alleen. Dat leverde veel spanningen op, omdat ze haar dochter op tijd van de crèche moest halen, terwijl de afhandeling van opvang van mensen nog niet geregeld was. Die spanningen werden haar soms te veel, en dan meldde ze zich daarna ziek. Toen dat probleem eenmaal boven tafel was gekomen hebben we de roostering van medewerkers opnieuw bekeken. Mevrouw $\mathrm{x}$ werkte vaak op vrijdag alleen, omdat veel van onze medewerkers part-time werken en de vrijdag vrij hebben. Nu hebben we die roostering veranderd, zodat mevrouw $\mathrm{x}$ niet meer alleén dienst heeft op vrijdagmiddag. Dat leidt tot minder spanningen, waardoor haar ziekteverzuim ook is godaald. Ook bij andere vrouwen blijken strakke werktijden vaak een probleem. Door flexibilisering van de werktijden en kleine veranderingen in de roosters proberen we mensen tegemoet te komen, die probiemen hebben met het realiseren van oppas voor de kinderen. Vaak maken deze aanpassingen een einde aan het verzuim.

De werkgever doet in het SMT verslag van de wijze waarop hij om is gegaan met het specifieke probleem van één van de medewerkers. Door een gesprek met de vrouw te voeren over de redenen van haar verzuim, heeft de werkgever zich eveneens afgevraagd of de problemen die de vrouw heeft niet ook bij andere werknemers spelen. Het afstemmen van roosters en diensten op privé-omstandigheden of wensen, blijkt een positief effect te hebben op het ziekteverzuim van deze medewerkers. Deze invulling van zijn verantwoordelijkheden als werkgever beïnvloeden de arbeidsongeschiktheid in positieve zin. Door de vragen van werkgevers over hoe zij om moeten gaan met (problemen van) zieke werknemers, niet direct te beantwoorden, maar terug te leggen bij werkgevers worden werkgevers gestimuleerd om verantwoordelijkheid te nemen om zelf voorstellen te doen over hoe zij zaken aan kunnen pakken.

Alhoewel werkgevers er toe aangezet worden om creatieve plannen te bedenken om de arbeidsongeschiktheid van een werknemer ten dele op te heffen, betekent dat niet per definitie dat werkgevers werknemers altijd de mogelijkheid moeten bieden om aangepaste werkzaamheden te kunnen verrichten. Het is eerder een inspanningsverplichting. waarover ze verantwoording moeten af leggen. Waar werknemers in gesprekken met verzekeringsartsen plausibel moeten maken dat hun klachten een belemmering vormen voor het uitvoeren van werkzaamheden, wordt van werkgevers verwacht dat ze plausibel 
maken dat het niet mogelijk is om aanpassingen in de werksituatie te creëren, die het mogelijk maken om een zieke werknemer werk te laten uitvoeren.

cl: ik heb met de leidinggevende gesproken, want ik wil graag arbeidstherapeutisch aan de slag. Maar de leidinggevende ziet dat niet zitten. $\mathrm{E} x$ zijn al te veel mensen arbeidstherapeutisch aan het werk (3), en ze vindt dat ik te weinig kan.

va: hoe lang kunt u uw prothese aanhouden?

cl: het wisselt, maar soms moet hij na $10 \mathrm{~min}$. echt af.

va: dat is ook wel heel kort. Ik kan me het standpunt van de leidinggevende wel voorstellen. $U$ kunt op de afdeling nauwelijks iets doen, zeker gezien het feit dat er al veel andere mensen rondlopen die alleen lichte werkzaamheden doen. Ik wil u graag over 5 weken terug zien, dan heeft u die nieuwe prothese. Als het in de tussentijd nou beter gaat, kunt u overleggen met uw leidinggevende over werk op arbeidstherapeutische basis. Misschien kan dat eventueel op een andere afdeling.

De werknemer wil graag op arbeidstherapeutisch basis aan het werk. De werkgever is echter van mening dat het niet mogelijk is aangepaste werkzaamheden aan te bieden. De verzekeringsarts vindt de argumenten van de leidinggevende redelijk, gezien de beperkingen van de vrouw èn de bijzondere situatie op de afdeling waar ze werkt. De arbeidsongeschiktheid wordt gehandhaafd, maar als de situatie van de vrouw verandert, moet de werkhervatting opnieuw worden bekeken. Ook de vraag of de situatie op de afdeling dan nog een belemmering vormt zal dan opnieuw op de agenda staan. De problemen die het grote aantal mensen dat al op arbeidstherapeutische basis werkt op de afdeling kan in principe immers omzeild worden door de vrouw tijdelijk op een andere afdeling werkzaamheden te laten verrichten. De vraag of de werkomstandigheden het toelaten of iemand wel of niet aangepaste werkzaamheden kan doen, moet steeds opnieuw door de werkgever beargumenteerd worden.

va: vorige keer hebben we afgesproken dat we nu afspraken zouden maken over uw werkhervatting, $u$ zou met uw werkgever een afspraak maken om de mogelijkheden bekijken, wat zei werkgever?

cl: we hebben geen concrete afspraken gemaakt, ik heb wel aangegeven dat ik per half juli weer halve dagen ga werken. Binnenkort gaan we preciezere afspraken maken.

va: het is nu begin juni, waarom pas half juli?

cl: dan is de verbouwing klaar, en is het wat rustiger

va: het verhaal is duidelijk, ik wil nu een principe afspraak maken over de werkhervatting: vanaf 11 juli op arbeidstherapeutische basis. Eind juli hebben wij een nieuwe afspraak, mocht dat niet haalbaar zijn dan moet $\mathrm{u}$ bellen.

De vrouw zou haar werk hervatten, maar door de verbouwing op haar werk, kan daar volgens de werkgever geen rekening mee gehouden worden. Alhoewel de vrouw eigenlijk wel eerder zou kunnen hervatten, wordt het argument van de werkgever dat de 
vrouw gezien de ongewone situatie op het werk haar werk niet kan doen, als redelijk beschouwd.

Wat wel en niet kan wordt niet zozeer door de situatie bepaald, als wel door de overtuigingskracht van de argumenten van de werkgever. Een voorbeeld uit de thuiszorg laat dat zien.

va: ik heb u ongeveer 6 weken geleden voor het laatst gezien, en a heef 4 weken geleden het werk hervat. Na drie weken heeft u zich opnieuw ziek gemeld.

cl: klopt, het ging eigenlijk heel goed, maar nu heb ik een ontsteking in m'n schouder......Nu ben ik weer aan het werk.

va: het werken ging goed, $w$ werkt voornamelijk in lichte gezinnen?

cl: ja, het ging goed, ik werk nu bij GGV (gezinnen die geestelijke verzorging krijgen = sociaalpsychologisch/maatschappelijk).

va: mooi, dus u heeft toch die plaats gekregen. U heeft alleen maar GGV-gezinnen?

cl: ja, in principe wel, dat ligt een beetje aan het aanbod.

va: en u heeft het werk weer helemal opgepakt?

cl: ja, voor $40 \mathrm{u}$.

va: en de werkgever zoekt lichte gezinnen?

cl: ja, 's middags ben ik arbeidstherapeutisch aan het werk 's ochtends werkt daar iemand anders, die het zware werk doet.

De vrouw heeft last van haar rug en heeft daardoor moeite met het verrichten van zware huishoudelijke werkzaamheden. Voor een werkgever in de thuiszorg is het niet goed mogelijk om de arbeidsomstandigheden in materiële zin aan te passen. Verzorgenden werken in privé-situaties met hulpmiddelen die de mensen die verzorgd worden zelf aanreiken. De werkgever heeft dan ook een andere oplossing bedacht, waardoor rekening gehouden kan worden met de belemmeringen van de vrouw. Enerzijds door gezinnen te zoeken waar de hulpverlening niet bestaat uit zware huishoudelijke werkzaamheden en anderzijds door het werk te verdelen. De vrouw doet in sommige gezinnen lichte huishoudelijke werkzaamheden en er komt iemand anders voor het zware werk. $\mathrm{Na}$ afloop van het gesprek geeft de verzekeringsarts aan:

va: bij de thuiszorg in $\times$ kan heel veel. Mensen doen dan lichte gezinnen, of andere thuishulpen komen dan de ramen wassen. Collega's in andere regio's reageren daar vaak verbaasd op. Maar hier gaat het goed, differentiatie is belangrijk. Er zit natuurlijk wel een grens aan, ik kan niet voor te veel mensen met beperkingen tegelijkertijd om aanpassingen vragen, dan wordt het voor anderen te zwaar.

Een voorbeeld uit een andere regio laat zien dat wat redelijke aanpassingen zijn niet vanzelf spreekt.

va: wat maakt het werk zwaar? 
cl: bij mensen thuis heb je vaak slecht materiaal en weinig hulpmiddelen, dan kan ik m'n nug niet ontzien.

va: wat doet $u$ er aan als dat erg slecht is?

cl: ik heb er wel eens over gesproken met m'n leidinggevende. Die gaat wel naar de mensen toe, maar als die geen dingen willen aanschaffen, houdt het op.

na afloop geeft de verzekeringsarts aan: Soms wou ik dat ik een andere werkgever had dan de thuiszorg. dan kon ik mensen wat anders laten doen. In de thuiszorg kan je het werk niet aanpassen.

De vrouw geeft aan dat ze haar werk niet kan hervatten omdat het te belastend is voor haar rug. De werkgever heeft geprobeerd om die situatie te veranderen, maar heeft daar volgens de vrouw weinig invloed op. De verzekeringsarts legt zich neer bij de arbeidsongeschiktheid van de vrouw en legitimeert zijn besluit door te wijzen op de bijzondere situatie in de thuiszorg. Omdat verzorgenden van een thuiszorgorganisatie bij mensen thuis werken, heeft de werkgever volgens de verzekeringsarts inderdaad weinig mogelijkheden om de situatie aan te passen. Alhoewel de verzekeringsarts weet dat zijn collega uit het vorige voorbeeld werkaanpassingen regelt door de organisatie van het werk en de taaktoewijzing te veranderen, staat hij op het standpunt dat in de thuiszorg in algemene zin geen werkaanpassingen mogelijk zijn. De argumenten van de werkgever, dat de vrouw geen rugsparende arbeid kan verrichten omdat de situatie in de gezinnen waar zij werkt niet aangepast kan worden, wordt door de verzekeringsarts plausibel gevonden.

Werknemers overleggen met hun werkgever over mogelijkheden om het werk aan te passen. Werkgevers worden verondersteld mee te werken aan het bedenken van oplossingen, of, als zij denken dat die niet mogelijk zijn, te beargumenteren waarom een werkaanpassing niet mogelijk is. In hoofdstuk 3 hebben we gezien dat in gesprekken tussen zieke werknemers en verzekeringsartsen arbeidsongeschiktheid gedefinieerd wordt als belemmeringen om het werk uit te voeren. Door die definiëring wordt aan werknemers, maar, zoals bovenstaande gespreksfragmenten laten zien, ook aan werkgevers een verantwoordelijkheid voor de oplossing van het probleem toebedeeld. De definiëring van het probleem in termen van werkhervatting en niet in termen van ziekte is niet zomaar een beschrijving van hetzelfde probleem in andere termen. Een andere probleemdefiniëring herbergt andere sociale en organisatorische veronderstellingen. Dat wordt zichtbaar als we ons de vraag stellen of oplossingen mogelijk zijn. In bovenstaande voorbeelden heeft het beantwoorden van die vraag slechts ten delen met de klachten van de werknemer te maken. De vraag of een werknemer (gedeeltelijk) arbeidsongeschikt is, is evenzeer afhankelijk van de mate waarin werkomstandigheden aangepast kunnen worden. Met andere woorden van de mate waarin werkgevers actief zoeken naar oplossingen en of zij al dan niet plausibel kunnen maken dat de belemmeringen niet opgeheven kunnen worden door werkaanpassingen. 


\section{Een open arbeidsrelatie}

De probleemdefinitie in de verzekeringsgeneeskundige praktijk, die gesteld wordt in termen van belemmeringen voor een werkhervatting, plaatst de ziekte in curatieve zin op de achtergrond en haalt de afstemming tussen datgene wat een werknemer kan en wat hij moet doen naar voren. Die afstemming is niet alleen afhankelijk van de klachten van zieke werknemers, maar evenzeer van de mogelijkheden die werkgevers zien om werktaken en omstandigheden aan te passen. Die afstemmingsproblematick is een kwestie die werknemers en werkgevers onderling bespreken. De consequentie daarvan is dat de vraag of iemand al dan niet arbeidsongeschikt is, mede bepaald wordt door de vraag in hoeverre werkgevers en werknemers er in slagen daar goede afspraken over te maken. Verzekeringsartsen zijn bij de uitvoering van de arbeidsongeschiktheidsbegeleiding en beoordeling afhankelijk van werkgevers en de wijze waarop werkgevers en werknemers gezamenlijk hun werkgever-werknemer relatie vormgeven. Waar verzekeringsartsen zich weinig bemoeien met de precieze vormgeving van de aangepaste werkzamheden, houden ze zich wel intensief bezig met de aard van die relatie. In vergelijking met de contacten die cliënten onderhouden met behandelend artsen, worden contacten tussen werkgevers en werknemers in de spreekkamer van de verzekeringsarts uitvoeriger nabesproken, in die zin dat zowel ingegaan wordt op datgene wat werknemer en werkgever afgesproken hebben, als op de wijze waarop die afspraken tot stand zijn gekomen en wat de opstelling van de werkgever daarbij is geweest. In deze gesprekken wordt een specifieke werkgever-werknemer relatie geconstrueerd.

Werknemers en werkgevers, zo hebben we gezien, voeren overleg met elkaar. Overleg voeren betekent in de eerste plaats praten over de praktische inrichting van de werkzaamheden.

cl: ....ik werk nu $2 \times 4$ uur en doe even geen GGV (gezinnen die geestelijke verzorging nodig hebben). daarnaast doe ik administratief werk, dat neem ik mee naar huis. Dat bevalt goed, want dan kan ik het doen als ik me kan concentreren.

va: op het werk heeft u aanpassingen makkelijk kunnen regelen?

cl: ja, dat ging heel goed.

De werkgever heeft, aldus de vrouw, meegewerkt aan het treffen van maatregelen om het mogelijk te maken dat de vrouw werkzaamheden verricht, en geen belemmeringen of bezwaren aangevoerd. Maar van werkgevers wordt meer verwacht dan dat zij meewerken aan 'organiseren' van aangepaste werkzaamheden. Bovenstaand gesprek gaat als volgt verder:

va: er is wel begrip voor uw situatie? 
cl: ja, de leidinggevende snapt het heel goed, ik mag de administratie doen als ik het kan, en ik wil wel graag halve dagen volhouden, de leidinggevende zegt ook, $100 \%$ kan even niet.

va: nog even over het werk, de leidinggevende coốrdineert het?

cl: ja, dat loopt heel goed.

Om die aanpassingen te regelen is het nodig dat de werkgever betrokkenheid toont bij situatie van de werknemer. Werkgevers kunnen een werknemer steunen bij de moeilijkheden die ze ondervinden door aandacht te even aan de kwetsbare situatie waarin deze verkeert. Om een werkhervatting succesvol te laten verlopen, is het maken van afspraken ten aanzien van aangepaste werkzaamheden niet voldoende, ook begeleiding en aandacht van de werkgever zijn daarvoor noodzakelijk.

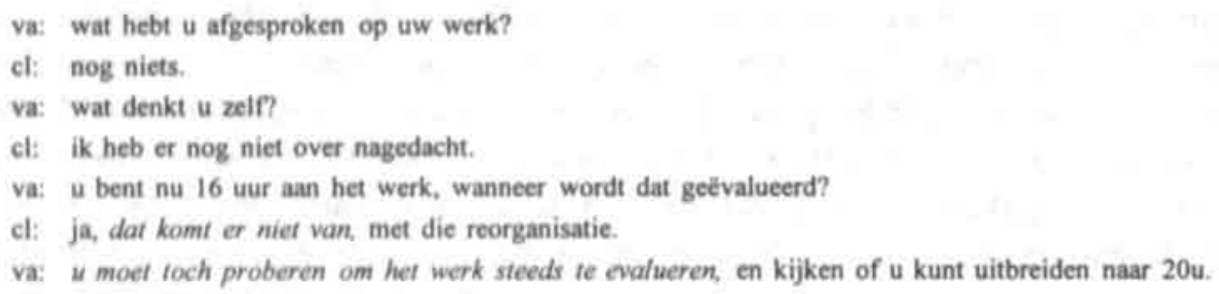

De vrouw heeft haar werkzaamheden gedeeltelijk hervat, maar spreekt niet met haar werkgever over hoe dat loopt. Om een terugkeer soepel te laten verlopen is het volgens de verzekeringsarts wel van belang dat de vrouw met haar werkgever evalueert hoe de werkhervatting onder aangepaste omstandigheden verloopt. Die evaluatie is een vorm van aandacht voor de vrouw en de vrouw moet zorgen dat ze die aandacht van haar werkgever krijgt.

Maar niet alleen werknemers worden gestimuleerd om werkgevers 'bij de les te houden'. Ook werkgevers zelf worden aangesproken op hun taak om mensen te stimuleren en te begeleiden. Bijvoorbeeld gedurende het SMT.

wg: deze vrouw heeft thuis veel problemen. Ze wil over een maand weer beginnen. Het liefst zou ze minder gaan werken, maar dat geeft financiële problemen. Wat is volgens u de prognose?

va: ze kan nog niet aan het werk. Maar $u$ kun wel stimuleren dat ze af en toe op het werk komt kijken.

Om een werkhervatting soepel te laten verlopen, is aandacht van een werkgever voor de situatie van de werknemer van belang. In hoofdstuk 3 is al aan de orde geweest dat werknemers gestimuleerd worden om contacten te onderhouden met hun werk. Werkgevers hebben eveneens een taak om aandacht te geven aan de (problemen van) zieke werknemers en verzekeringsartsen stimuleren werkgevers om daar een actieve rol in te spelen. De werkgever wordt door de verzekeringsarts aangesproken op zijn rol bij de 
begeleiding van de vrouw. Als werkgevers die taak op zich nemen, worden werknemers door zowel verzekeringsartsen als hun werkgevers aangesproken op hun verantwoordelijkheid als werknemers om contacten op het werk in tact te houden. Werkgevers hebben de verantwoordelijkheid om werknemers daar in te ondersteunen.

$\mathrm{Om}$ een werkhervatting succesvol te laten verlopen hebben verzekeringsartsen een specifieke werknemer-werkgever relatie nodig, die zich kenmerkt door een 'open' karakter. Dat betekent op de eerste plaats dat werkgever en werknemer moeten overleggen over werkaanpassingen en dat de problemen van werknemers bespreekbaar moeten zijn. Zowel werkgevers als werknemers hebben een verantwoordelijkheid voor de werkgeverwerknemer relatic. Problemen die werknemers signaleren ten aanzien van het gedrag van hun werkgevers, moeten zij zelf met werkgevers bespreken. Werknemers geven bijvoorbeeld regelmatig aan dat de werksfeer of de cultuur van een organisatie parten speelt in de arbeidsongeschiktheid.

va: mogelijk komt het door spanningen, is dat op het werk of prive?

cl: de sfeer op het werk is niet goed. Soms wordt het me te veel. Er wordt nu ook gestolen, en we draaien veel overdiensten, omdat er zoveel mensen ziek zijn.

va: heeft u deze problemen wel eens op het werk besproken?

cl: nee, niet echt.

va: dat moet u wel doen, $u$ moet het maar eens gaan uitpraten bij personeelszaken.

cl: ik weet het niet, ik moet me eerst beter voelen.

va: ja, maar uw klachten hebben juist met het werk te maken, daarom moet u gaan praten. $U$ maakt een afspraak met personeelszaken, en ik ga het ook met uw werkgever bespreken.

cl: misschien is het toch wel goed om te praten.

De vrouw geeft aan dat haar klachten misschien veroorzaakt worden door de sfeer op het werk. De verzekeringsarts stimuleert de vrouw om daar over te praten met haar werkgever. In een werknemer-werkgeverrelatie zouden dergelijke zaken bespreekbaar moeten zijn. De verantwoordelijkheid van werknemers, zoals die in gesprekken met verzekeringsartsen geconstrueerd wordt, heeft niet alleen betrekking op het uitvoeren van werkzaamheden die ze gewoonlijk doen, maar gaat verder. Werknemers hebben tevens een verantwoordelijkheid voor het onderhouden van een open relatie met de werkgevers. Dat betekent enerzijds het bespreekbaar maken van problemen die werknemers zelf ervaren en anderzijds het aanspreken van de werkgever op diens verantwoordelijkheid om wat met die problemen te doen.

In een werkgever-werknemer relatie moeten achterliggende problemen en onvrede geuit kunnen worden. Werknemers hebben een plicht dat te doen, de verzekeringsartsen leren werknemers hoe ze dat kunnen doen. Maar ook werkgevers hebben een verantwoordelijkheid voor het creëren van een open sfeer. 
[Tijdens een SMT in een verpleeghuis brengt de personeelsfunctionaris een ziekenverzorgende ter sprake:]

wg: mevrouw $\times$ werkt nu enige tijd halve dagen op arbeidstherapeutische basis. Volgens haar leidinggevende doet ze haar taken wel langzaam, maar gaat dat redelijk goed. De collega's geven echter aan dat $z e$ problemen hebben met haar sociale functioneren in het team. Ik weet niet zo goed wat we daarmee moeten doen.

ya: is daar met mevroww zelf al eens over gesproken? Heeft de personeelsfunctionaris of de leidinggevende dat bij de evaluatie van haar werk al eens besproken?

wg: nee, we weten niet zo goed wat we er mee moeten.

va: ik denk dat u dat dan maar eens moet gaan doen. Vraagt u haar eens hoe ze self vindt dat het gaat, ook ten aanzien van de samenwerking met anderen.

wg: dat is misschien wel goed. Haar direct leidinggevende is ook niet altijd even begripvol, misschien kijkt mevrouw zelf daar wel anders tegen aan.

De werkgever vraagt aan de verzekeringsarts wat hij het beste kan doen met het probleem dat het functioneren van de vrouw klachten oproept bij collega's. De verzekeringsarts geeft geen inhoudelijke oplossing, maar legt het probleem terug bij de werkgever. De personeelsfunctionaris realiseert zich dan dat de vrouw zelf misschien wel anders tegen de situatie aan kijkt en wil daar met de vrouw zelf over praten. Het bespreekbaar maken van ongenoegens behoort tot de verantwoordelijkheid van werkgevers. Werkgever en werknemer zijn gezamenlijk verantwoordelijk voor het creëren van een open relatie. Niet alleen werknemers worden daartoe aangezet. Ook werkgevers worden aangemoedigd om open overleg te voeren en zaken bespreekbaar te maken.

Ook in het geval van conflicten, worden het bespreken van problemen en het zoeken naar oplossingen in de eerste plaats gezien als kwesties die werkgevers en werknemers aangaan.

[belanghebbende is secretaresse op een afdeling in het ziekenhuis. Ze werkt daar nu 2 jaar.]

va: U heeft zich 3 weken geleden ziek gemeld, bent $u$ inmiddels weer in staat om te werken?

cl: nee, ik denk het niet, ik ben helemaal op, ik heb een conflict met éen van bazen, dat is helemaal uit de hand gelopen. Ik heb twee jaar gevochten om het goed te krijgen, ik kan niet meer.

va: hoe denkt u dat het nu verder moet? krijgt u hulp?

cl: Ik ben bij de bedrijfsarts geweest en ook bij de huisarts. En ik heb een gesprek met de clustermanager gehad, en er volgt er mu nog een. Ik kan me daar erg over opwinden. Ik wil graag dat m'n man meegaat, dan blijf ik rustiger, maar dat mag niet. Zij zitten wel met meerderen, maar ik moet het allemaal alleen doen. Maar goed, ik wil wel dat het opgelost wordt, dus ik ga er toch maar weer heen.

va: wat wilt u zelf? een overplaatsing?

cl: eigenlijk wil ik eerst een gesprek met die baas, om de boel uit te praten, maar dat gaat nu niet, want hij is op vakantic.

va: laten we ewen afwachten hoe het volgende gesprek verloopt. Als het nodig is kunnen we daarna ook de arbeidsconsulent er nog bij betrekken. Ik wil u volgende week even terug zien. 
een week later:

va: hoe is het gesprek verlopen

cl: ik ben er niet negatief over. We hebben een twee sporen beleid afigesproien. Ik ga het eerst nog een half jaar proberen op de afdeling, met begeleiding vamit personeelszaten. Als dat niet goed gaat dan gaan we kijken naar een andere afdeling.

$\mathrm{Na}$ afloop geeft de verzekeringsgeneeskundige aan: dat wordt goed geregeld. De bedrijfsarts en personeelszaken zijn er bij betrokken. Dan hoef ik de arbeidsconsulent niet in te schakelen.

Vanuit de dienst personeelszaken wordt de vrouw begeleid, worden haar problemen bespreekbaar gemaakt en wordt naar oplossingen gezocht. Een sterk ontwikkeld oplossend vermogen van werknemers en werkgevers, ook in geval van confliet, houdt de verzekeringsarts op de achtergrond. De arbeidsongeschiktheidsbegeleiding en -beoordeling loopt vanzelf.

Naast het regelen van organisatorische kwesties, het begeleiden en het bespreekbaar maken van ongenoegens over het werk, wordt een 'open' werknemer-werkgever relatie gekenmerkt door het feit dat werknemers en werkgevers elkaar kunnen aanspreken op gemaakte afspraken.

va: u lacht nog gelukkig, hoe is het?

el: beter, ik kan me beter concentreren. Ik heb gebeld naar het werk voor een afspraak, ze zouden terug bellen, maar dat is niet gebeurd.

va: nou dan moeten ze zelf maar ergens mee komen.

wat wilt u zelf?

cl: nou, niet te zwaar werk, dat zou geregeld worden.

va: weet u wel wat ze met u van plan zijn?

cl: ja, ze willen me op een nieuwe afdeling plaatsen.

va: nou, u moet zelf nog maar een keer contact opnemen. Dan maken wij voor over 3 weken een afspraak.

De man heeft contact met zijn werkgever gehad en die zou hem terugbellen om afspraken te maken. In eerste instantie lijkt de verzekeringsarts dat een tekortkoming van de werkgever te vinden. Toch moet de werknemer, nu de werkgever het laat afweten, zelf opnieuw initiatief nemen. Het ontwikkelen van plannen door werknemers en werkgevers om een werkhervatting vorm te geven is niet vrijblijvend. Werknemers en werkgevers maken daar, net als werknemers en verzekeringsartsen, afspraken over. Van beide partijen wordt verondersteld dat ze zich aan die afspraken houden, maar ook dat zij elkaar onderling aanspreken op die afspraken.

va: dat moet u goed met de leidster afspreken. Heeft het gesprek iets opgelost?

cl: nou, dat is even afwachten, de afspraak is mis gelopen.

va: dat is ook uw verantwoordelijkheid. Ik wil u over 3 weken terug zien. 
na afloop geeft de verzekeringsarts aan: dit is een vervelende werkgever, ze vinden ons te soft, maar het heeft geen zin om harder op te treden, dan zie je ze zo weer tenug. De vrouw moet door de werkgever beter begeleid worden.

De verzekeringsarts stimuleert de vrouw om haar werkgever aan te spreken op zijn verantwoordelijkheid maar geeft na afloop te kennen dat ook de werkgever zich onttrekt aan zijn verantwoordelijkheid om op serieuze basis met de vrouw te praten. De werkgever zou de vrouw meer moeten aanspreken op haar verantwoordelijkheden om haar taken goed te vervullen, de werknemer moet haar werkgever aanspreken op zijn verantwoordelijkheid om zich aan afspraken te houden. Behalve verantwoordelijke werknemers heeft de verzekeringsarts ook verantwoordelijke werkgevers nodig, om de arbeidsongeschiktheidsbegeleiding goed vorm te geven. Om werknemers hun verantwoordelijkheid op te laten nemen, is het van belang dat niet alleen de verzekeringsarts, maar ook de werkgever een werknemer daarop aanspreekt. Als een werkgever dat niet doet, kan de werknemer zich alsnog aan zijn verantwoordelijkheden onttrekken. Na een gesprek met een cliënt geeft de verzekeringsarts het volgende aan:

va: heilloos, de werkgever spreekt haar wel aan, maar niet echt. Dat moet ik van ze doen. Ik stuur haar elke keer weer aan het werk, ik heb met haar besproken dat ze ander werk moet gaan doen, maar dat ziet ze niet zitten. En de werkgever is er nog niet aan toe om een ontslagaanvraag in te dienen. Bij organisatie $\mathrm{x}$ is dat wel anders, als mensen daar niet functioneren worden ze daar op aangesproken; er worden afspraken met ze gemaakt en als mensen zich daar niet aan houden zijn er gronden voor een ontslag aanvraag. Je moet mensen ook aanspreken op hun functioneren.

De vrouw wordt door de verzekeringsarts steeds aangesproken op haar verantwoordelijkheden als werknemer, maar de werkgever spreekt haar daar niet op aan. Daardoor wordt het volgens de verzekeringsarts voor de vrouw gemakkelijk om zich steeds weer ziek te melden.

Het zoeken naar oplossingen voor de belemmeringen die een werknemer ervaart bij de uitvoering van de werkzaamheden is een verantwoordelijkheid van werknemers en werkgevers. In gesprekken tussen werknemers en verzekeringsartsen en in gesprekken tussen werkgevers en verzekeringsartsen worden zowel werknemers als werkgevers aangesproken op hun verantwoordelijkheid om een dusdanige relatie te onderhouden, dat ze die verantwoordelijkheid ook kunnen dragen. Dat betekent dat een werkgever-werknemer relatie er een moet zijn van open overleg. Dat open overleg houdt enerzijds in dat problemen en ongenoegens bespreekbaar gemaakt worden, zodat ruimte ontstaat voor wederzijds begrip. Maar anderzijds heeft dat overleg een zakelijke dimensie. Problemen en ongenoegens zijn geen reden om ontslagen te worden van redelijke verplichtingen, een open relatie betekent eveneens dat werkgevers en werknemers elkaar aanspreken op 
verplichtingen als werknemer en werkgever. Een dergelijke werkgever-werknemerrelatie wordt in de gesprekken geconstrueerd.

\section{Normen voor goed werkgeverschap}

De definiëring van het probleem in termen van belemmeringen voor de werkhervatting en het in eerste instantie toewijzen van verantwoordelijkheid voor het oplossen van het probleem aan de cliēnt, geeft werkgevers een positie binnen de arbeidsongeschiktheidsbegeleiding en -beoordeling. Cliënten hebben, om hun verantwoordelijkheid als werknemers op te nemen, hun werkgever nodig. De vraag of werknemers al dan niet arbeidsongeschikt zijn is niet alleen afhankelijk van hun klachten, maar evenzeer van de mate waarin werkaanpassingen mogelijk zijn. De vraag of werkaanpassingen mogelijk zijn, is een kwestie die werkgevers en werknemers in onderling overleg beantwoorden. Werkgevers krijgen daarmee een stem in de bepaling van arbeids(on)geschiktheid.

De definiëring van arbeidsongeschiktheid op deze manier en niet in termen van gezondheidsklachten, $\mathrm{zo}$ is in het vorige hoofdstuk aan de orde geweest, plaatst behandelend artsen buiten het domein van verzekeringsartsen. Werkgevers worden in het verlengde van die definitie en in samenhang met de verantwoordelijkheden die werknemers krijgen toegewezen centraal in dat domein gepositioneerd. Naast het organiseren van werkaanpassingen hebben werkgevers een verantwoordelijkheid voor het creëren van een open werkgever-werknemer-relatie waarin ruimte is voor het bespreken van problemen en fricties, maar ook het wederzijds aanspreken op gedrag mogelijk is. Werkgevers worden gestimuleerd om die verantwoordelijkheid op te nemen en er door verzekerings* artsen op aangesproken. Verzekeringsartsen spreken werknemers en werkgevers op vergelijkbare manier, met vergelijkbare middelen aan. Beiden worden gestimuleerd om hun verantwoordelijkheid op te nemen. Verantwoord werkgeverschap is nodig om verantwoorde werknemers te creëren en daarmee is de medewerking van werkgevers van belang voor het uitoefenen van de verzekeringsgeneeskundige taak.

De wijze waarop de verantwoordelijkheidstoewijzing naar werkgevers en werknemers gestalte krijgt, laat tegelijkertijd nieuwe implicaties zien van de definiëring van arbeidsongeschiktheid in termen van belemmeringen rond de werkhervatting en niet in termen van gezondheidsklachten. Het spreken over belemmeringen voor de werkhervatting en het naar achter schuiven van de gezondheidsklachten in curatieve zin, creëert ruimte om belemmeringen voor een werkhervatting in algemene zin te bespreken. Het stimuleren en bespreken van verantwoordelijk werknemers- en werkgeversgedrag kan een zelfstandige plaats krijgen in de gesprekken. De definitie van het verzekeringsgeneeskundig domein in termen van het verhelpen van belemmeringen in de werkhervatting, schept de mogelijkheid om die conflicten of problemen in de arbeidsrelatie centraal te stellen. Hierdoor behelst die deskundigheid niet alleen een werkgeoriënteerde benadering van gezondheids- 
klachten, maar het gezond houden van een werkgever-werknemer relatie. In feite raakt die deskundigheid tot op bepaalde hoogte los van gezondheidsklachten.

\section{Werkgevers als probleem}

"..m'n werkgever vindt het beter om eerst de onderzoeksuitslagen af te wachten."

Het functioneren van de praktische logica in de verzekeringsgeneeskundige praktijk staat of valt met de mate waarin diverse betrokkenen zich conformeren aan de probleemdefiniëring door het opnemen van de verantwoordelijkheden die daarmee samenhangen. Waar werknemers zich, door in de gesprekken te volharden in een curatieve probleemdefinitie en zich in eerste instantie te beroepen op hun behandelend artsen of therapeuten, kunnen onttrekken aan hun verantwoordelijkheid, kunnen werkgevers dat ook. Dat het meewerken aan een oplossing voor de arbeidsongeschiktheid van een werknemer een verantwoordelijkheid is van de werkgever, is voor de hand liggend door de specifieke probleemdefinitie die gesteld is in termen van belemmeringen voor de werkhervatting. Vanuit een medisch georiënteerde definitie van de situatie is de betrokkenheid van werkgevers allerminst vanzelfsprekend. Zo'n definitie legt de oorzaak van het probleem immers in het 'lichaam' van cliënten, maakt van cliënten patiënten, hetgeen hen juist (tijdelijk) ontslaat van verantwoordelijkheden als werknemers. De vanzelfsprekendheid van een werkgeversverantwoordelijkheid bij de arbeidsongeschiktheidsbegeleiding en beoordeling is dan ook gekoppeld aan de specifieke definitie van het probleem dat op de agenda staat. Niet alleen werknemers ook werkgevers kunnen zich onttrekken aan die verantwoordelijkheid door zich niet te binden aan die probleemdefinitie. Een werkgever die het zoeken naar mogelijkheden voor een werkhervatting niet tot zijn taak rekent, verstoort daarentegen, ook als cliënten wel hun verantwoordelijkheden willen opnemen, de orde in het verzekeringsgeneeskundig domein. Verzekeringsartsen zijn voor de uitoefening van hun zeggenschap in grotere mate afhankelijk van werkgevers dan van behandelend artsen. Waar de invloed van behandelend artsen als deze er een andere probleemdefinitie op na houden, in een aantal gevallen gepacificeerd kan worden door de cliënt los te weken van de behandelend arts, belemmeren werkgevers die zich onttrekken aan hun verantwoordelijkheid de constructie van cliënten tot werknemers. In deze paragraaf ga ik in op wat er gebeurt als werknemers en/of werkgevers volharden in het feit dat zij de oplossing van de werkhervatting niet als ook hun probleem definiëren.

\section{Wijzen op verantwoordelijkheid}

In de verzekeringsgeneeskundige praktijk wordt een werkgever-werknemer relatie geconstrueerd, zodanig dat het zoeken naar oplossingen om een werkhervatting mogelijk te maken een verantwoordelijkheid voor werknemers en werkgevers gezamenlijk wordt. 
Daarvoor is, zo blijkt uit de gesprekken, een specifieke werkgever-werknemer relatie nodig, waarbinnen werkgevers en werknemers in redelijkheid met elkaar overleggen, problemen bespreekbaar maken, zich aan afspraken houden en elkaar aanspreken op deze verantwoordelijkheden. Door het voortdurend aanspreken op die verantwoordelijkheden worden zowel werkgevers als werknemers gebonden aan hun rol. Die rolverdeling hebben verzekeringsartsen nodig om hun taak uit te kunnen voeren, of zeggenschap binnen hun domein effectief te kunnen maken. Zowel werkgevers als werknemers onttrekken zich bij tijd en wijle aan de verantwoordelijkheden, die horen bij deze definitie van een werkgever-werknemerrelatic. Deze situatie is ten dele vergelijkbaar met situaties waarin een op ziekte georiēnteerde probleemdefinitie centraal staat. In gesprekken waarin een op ziekte georiënteerde probleemdefinitie op de agenda staat, zo hebben we in het vorige hoofdstuk gezien, onttrekken werknemers zich aan hun werknemersrol. Ze definiëren zichzelf als zieken en richten zich op behandelend artsen en therapeuten. Verzekeringsartsen reageren hierop door te proberen cliënten aan zich te binden, maar als dat niet lukt houdt het op. Ze ondernemen nauwelijks actie in de richting van behandelend artsen. Als in gesprekken tussen verzekeringsartsen en zieke werknemers echter blijkt dat werkgevers zich, volgens cliënten, niet aan hun werkgeversverantwoordelijkheden houden, ondernemen verzekeringsartsen vaak wel actie, bijvoorbeeld door de werkgevers direct aan te spreken op hun verantwoordelijkheden.

va: u gaat nu binnenkort naar een psycholoog en u heeft een gesprek gehad met directeur?

cl: ja, dat gesprek is goed verlopen, ze zeggen zelf ook dat ze te veel op mij steunen, de problemen zijn doorgesproken, er worden een aantal van mijn taken bij anderen gelegd, en mijn leidinggevende wordt aangesproken op haar verantwoordelijkheid in de begeleiding. ze zijn ook bezig om een 'wepper' (werkervaringsplaats) aan te nemen om mij te ondersteunen, ik wil wel aan de slag. directeur vindt beter om even psycholoog af te wachten.

va: ... over twee weken hebben we opnieuw een gesprek. Daarvoor wil ik dat u nog contact opneemt met de werkgever om te horen hoe de situatie staat en dan hoor ik ook wat de psycholoog zegt. De arbeidsconsulent hoeft nog niet ingeschakeld, er is genoeg initiatief en dat lijkt ook wat te worden. Als er problemen optreden doen we dat alsnog.

De vrouw heeft in een gesprek met de directeur gesproken over veranderingen in haar werk die het mogelijk moeten maken dat zij haar werk weer hervat. In het volgende gesprek dat de vrouw heeft op haar werk, blijkt dat de zaken niet geregeld zijn. In het verslag dat de vrouw aan de verzekeringsarts doet geeft zij aan dat de werkgever onduidelijk is over de vraag of hij die toezeggingen nu door gaat voeren.

va: ...en gesprek met coôrdinator?

cl: dat ging slecht, hij was heel sceptisch, ik wilde graag IX per week overleg. nou vond hij niet nodig. 
va: u zou structurele afspraken willen maken over begeleiding?

cl: ja, uiteindelijk zei hij als het dan moest, dan wou hij dat wel doen. Toen heb ik nog gevraagd over ondersteuning als ik terug kwam, van die 'wepper' (werkervaringsplaats). Daar kon hij niets over zeggen, niet wanneer die komt en het is bovendien onduidelijk of er wel geld voor is.

va: dat komt niet overeen met afspraken die u heeft met directeur?

cl: nee, ik snap het ook niet, een andere coördinator vertelde me dat er een 'wepper' komt in september, waarom heeft hij dat dan niet gezegd?

va: dat is allemaal vervelend, u zegt dat uw klachten er ook door zijn toegenomen, ik zal van onze kant wat meer laten doen. Ik zal de arbeidsconsulent inschakelen, want aan deze onzekerheid moet een einde komen.

cl: m'n grootste angst is die werkdruk, als ik terug kom en alles komt weer over me heen, ik kan niets half doen, dus ben erg bang dat ik heel snel weer terug bij af ben.

va: we spreken af dat arbeidsconsulent het een en ander uitzoekt, $u$ heeft ook nog een afspraak bij psycholoog, en over twee weken zie ik u terug, dan kijken we verder.

Uit het gesprek dat de vrouw met de coördinator van de afdeling heeft gehad, blijkt dat de toezeggingen van de directeur niet gerealiseerd zijn. Nu de werkgever zich niet aan de afspraken blijkt te houden, stuurt de verzekeringsarts de arbeidsconsulent op de werkgever af. Die arbeidsconsulent moet bij de werkgever de afspraken na gaan. De werkgever zal gevraagd worden om verantwoording. Werknemers en werkgevers maken afspraken, en het karakter van afspraken is dat je mensen er op kunt aanspreken om ze na te komen. In de eerste plaats is dat een taak van werknemers zelf, maar verzekeringsartsen zien dat eveneens als hun taak.

In het kader van de arbeidsongeschiktheidsbegeleiding en -beoordeling worden ook afspraken gemaakt met werkgevers ten aanzien van meer permanente aanpassingen. Deze aanpassingen hebben veelal betrekking op de 'fysieke' arbeidsomstandigheden, en komen tot stand op advies van de arbeidsconsulent. Dergelijke aanpassingen en afspraken hebben een langere geldingsduur dan de specifieke verzuimperiode van een werknemer, naar aanleiding waarvan dergelijke afspraken gemaakt worden.

[belanghebbende werkt gedeeltelijk als groepsleidster en gedeeltelijk als huishoudelijke hulp. Een aantal jaar geleden is afgesproken met de werkgever dat de vrouw geen zwaar werk kan doen.]

va: ik heb van de rapporteur gehoord welke klachten u heeft, zou u nu weer aan het werk kunnen?

cl: nee, ik heb veel pijn, de laatste drie weken is het niet beter geworden. Het zat eerst alleen rechts, maar nu ook links.

va: wat is de oorzaak?

cl: overbelasting. Door de reorganisatie heb ik ander werk gekregen. Ik heb deze klachten al eerder gehad, toen ben ik via de arbeidsconsulent in overleg met de werkgever in aangepast werk geplaatst.

va: wat zeggen ze op het werk?

cl: ze hebben geen aandacht voor de klachten. 
cl: het komt door die reorganisatie. en het nieuwe hoofd luistert helemaal niet naar de klachten, dat was bij het oude hoofd veel beter.

va: ik vind het toch een verannwoondelijkheid van de werkgewer, zeker gezien het vorige atvies en de afspraken die toen gemaak sijn. Ik wil opnieuw de arbeidsconsulent inschakelen, die neemt contact met u op en inventariseen de situatie op uw werk.

cl: over een paar weken is de verbouwing afgelopen, dan keert de oude situatie weer terug. dan ga ik weer gewoon $m$ 'n oude werk doen.

va: ik wil toch dat de arbeidsconsulent even contact opneemt, want de werkgever howdt zich niet aan de afspraken.

De vrouw werkt normaal gesproken onder aangepaste omstandigheden, daar zijn in het verleden afspraken over gemaakt tussen de werkgever, de werknemer en de verzekeringsarts. De werkgever heeft daar nu verandering in aangebracht. Ondanks het feit dat die verandering een tijdelijk karakter heeft, vindt de verzekeringsarts dat de werkgever zich rekenschap moet geven van die afspraken. Hij gaat dan ook, via zijn verlengde arm, de arbeidsconsulent, met de werkgever praten, om hem te wijzen op een afspraak uit het verleden. Het aanspreken van werkgevers op hun verantwoordelijkheid om zich aan afspraken te houden die een werk voor werknemers mogelijk maken, rekent de verzekeringsarts tot zijn taak.

Die definitie van hun taak hangt samen met de relatie tussen werkgevers en de verzekeringsartsen. Waar behandelend artsen en verzekeringsartsen geen formele afspraken hebben over hoe zij met elkaar omgaan, zijn in het verzuimbeleid van een instelling, dat meestal in overleg met de verzekeringsartsen tot stand is gekomen, niet alleen taken van werknemers vastgelegd, maar eveneens verplichtingen voor de werkgever. In het verzuimprotocol zijn afspraken vastgelegd over het onderhouden van contacten met zieke werknemers en het in overleg met werknemers nagaan of er mogelijkheden zijn om een werkhervatting gestalte te geven. Het aanspreken van werkgevers door verzekeringsartsen vindt plaats tegen die achtergrond. Werkgevers die in meer algemene zin niet voldoende initiatief tonen, kunnen ook op grond van deze afspraken worden aangesproken.

[belanghebbende werkt bij een bureau dat trainingen en opleidingen verzorgd, een 'vreemde' werkgever volgens de verzekeringsarts.]

va: wat is het probleem, waaraan merkt u dat het niet gaat?

cl: stress, ik wordt helemaal gek van het werk, ik kan niet slapen, m'n geheugen is een zeef, ik kan me niet concentreren en eet nauwelijks meer.

va: komt dat door het werk? Wat zit daar niet goed?

cl: ja, ze manipuleren je de hele tijd, je moet keihard werken, het is nooit goed, en er komen voonturend dingen bij.

va: en wat nu? Wilt u nog terug?

cl: nee, ik wil nooit meer terug.

va: maar wat dan? Gaat u ontslag nemen?

cl: Ik weet het niet, ontslag nemen is niet mogelijk. 
va: niet mogelijk?

cl: dat zegt m'n advocaat.

va: ik schakel de arbeidsconsulent in, dan gaan wij met uw werkgever praten

cl: kan ik wel op vakantie?

va: ja, dat is geen probleem. Zodra u terug bent neemt de arbeidsconsulent contact met u op.

In dit geval is de werkgever-werknemer-relatie dusdanig verstoord, dat de werknemer niet zelf hoeft te overleggen. Er wordt direct een arbeidsconsulent ingeschakeld om te kijken of de werkgever te bewegen is tot goed werkgevers gedrag.

Het kader dat door afspraken wordt gevormd, zowel de afspraken in individuele gevallen als die die hun basis hebben in het verzuimprotocol, wordt door de verzekeringsarts tot bondgenoot gemaakt. Deze werkgevers hebben zich in eerdere instantie bereid verklaard hun medewerking te verlenen en de verantwoordelijkheid voor de arbeidsongeschiktheidsbegeleiding ten dele op zich genomen. Die afspraken maken het mogelijk om werkgevers te binden en actief aan te spreken. In vergelijking met behandelend artsen definiëren verzekeringsartsen hun positie ten opzichte van werkgevers sterker. Alhoewel KNMG en de uitvoeringsinstellingen ook regels hebben geformuleerd, doen verzekeringsartsen daar in de praktijk naar behandelend artsen nauwelijks beroep op, terwijl afspraken met werkgevers voldoende steun bieden om confrontaties aan te gaan.

\section{Werkgevers buiten spel}

Toch zit ook aan het confronterend optreden in de richting van werkgevers een grens. Die grens hangt samen met manier waarop verzekeringsartsen het succes van een arbeidsongeschiktheidsbegeleiding definiëren. In de relatie tussen werknemers en verzekeringsartsen hebben we al gezien dat verzekeringsartsen het gebruik van dwang bij het beëindigen van de Ziektewet als een soort zwaktebod zien. De effectiviteit van een begeleiding is gelegen in het accepteren van de verantwoordelijkheden door de werknemer zelf. De aanmoediging aan werknemers en werkgevers om zelf hun verantwoordelijkheden gezamenlijk op te nemen, laat zien dat niet alleen het verkrijgen van de medewerking van werknemers maar ook het verkrijgen van de medewerking van werkgevers gebaseerd is op het stimuleren van een eigen verantwoordelijkheid.

In een aantal gevallen maken werknemers plausibel dat werkgevers hun verantwoordelijkheden niet goed op zich nemen. Ze onttrekken zich dan bijvoorbeeld aan de plicht om redelijk overleg te voeren met de werknemers.

[belanghebbende is door de rapporteur bezocht als gevolg van een spoed oproep. Ze heeft conflicten op haar werk. De rapporteur trof de vrouw werkend in de tuin, ze had hoofdpijn en moest veel hoesten. maar het leek volgens de rapporteur niet erg serieus, daarom heeft hij de vrouw direct opgeroepen voor het spreckuur van de verzekeringsarts. De verzekeringsarts constateert dat de vrouw geen verzuimverleden heeft. $\mathrm{Ze}$ werkt volgens de verzekeringsarts voor een 'rare' leidinggevende, die veel conflicten 
heeft met zijn personeel. Hij vraagt altijd om een spoedcontrole. De verzekeringsarts vindt dat onzin, maar de leidinggevende is niet van het idee af te brengen.]

va: u heeft zich ziek gemeld met klachten hoofdpijn en hoesten. De rapporteur is meteen bij u langs gekomen ondat de werkgever een spoedcontrole had aangevraagd. Volgens de werkgever heeft u zich ziek gemeld in verband met de weekend dienst die u moet gaan draaien (het is vrijdag).

cl: dat ging allemaal heel raar, ik had de bel niet gehoord en was gewoon in de tuin aan het werken. Die spoedcontrole is omdat ik geen vroege diensten kan draaien. Ik ben gewoon heel verkouden, en moet al een tijdje erg hoesten, en 's nachts heb ik hoofdpijn. Ik mag toch wel $m$ 'n bed uit. Die rapporteur deed heel aanvallend, moet ik met die bloedhitte dan in m'n bed blijven liggen in een kamer waar het niet te harden is? Die klachten gaan niet over, dat heeft te maken met m'n moeder, die is opgenomen in het ziekenhuis met een tumor.

va: weten ze dat op an werk?

cl: nee, dat kan ook niet. Dat is jouw probleem, niet het hunne, dat weet ik wit envaring. Het is net als met de werktijden. Ik kan niet om 7 uur 's ochtends beginnen vanwege m'n zoontje, dat weten ze, maar er valt niet over te praten. We hadden eerst andere diensten, maar nu moeten we opeens ook de vroege diensten draaien. Een collega heeft er nu een beroepszaak over gewonnen, maar er valt nog steeds niet over te praten.

va: als ik het goed begrijp lopen er een aantal dingen niet lekker, thuis niet en op het werk niet, en daardoor gaan de klachten niet over. gebruikt u medicijnen?

cl: ja, en ik heb de huisarts gebeld, die zegt dat ik veel moet drinken, met dat warme weer moet ik zorgen dat ik voldoende vocht binnen krijg.

va: u verklaart het feit dat de werkgever een spoedcontrole heeft aangevraagd door de werksfeer, wat bent u nu van plan?

cl: ik wil nu eigenlijk 6 dagen in de Ziektewet blijven, ik moet echt even uitrusten, daarna heb ik 8 dagen vrij, dan meld ik me weer beter

va: laten we dat maar afspreken.ik kan me goed voorstellen dat $u$ uw werkgever niets verteld heeft in die werksfeer

De vrouw heeft in het verleden al vaker problemen gehad met haar werkgever, waaruit blijkt dat de werkgever niet bereid is met de werknemer te overleggen. Ook de verzekeringsarts heeft al vaker met de leidinggevende van de vrouw te maken gehad. Op grond van die ervaringen begrijpt de verzekeringsarts dat de vrouw niet met haar werkgever tot afspraken kan komen. Alhoewel de problemen met haar werkgever een belemmering vormen voor de vrouw om haar werk te hervatten, gaat de verzekeringsarts niet over tot het bespreken van die problemen met de werkgever. De opstelling van de werkgever lijkt dusdanig dat het hier geen zin heeft hem aan te spreken op zijn verantwoordelijkheid. De vrouw krijgt enkele dagen om bij te komen en gaat daarna weer aan het werk. In feite ziet de verzekeringsarts hier eigenlijk geen mogelijkheden om zijn taak uit te voeren.

Als argumenten van werknemers plausibel lijken, zoeken verzekeringsartsen soms ook naar andere oplossingen.

va: ik heb begrepen van uw werkgever dat u morgen weer 12 uur per week gaat werken. 
cl: ja, dat heeft hij geregeld, hij heeft me gewoon ingepland, vanmiddag moet ik even bellen.

va: $e r$ is geen overleg over geweest?

cl: nee.

va: wilt $u$ nog wel terug naar ...?

tan

va: bel wel vanmiddag ook even met de leidinggevende. Gaat u nu werken?

cl: liever niet.

va: nou dan maken we een afspraak voor over twee weken.

na afloop zegt de verzekeringsarts: die leidinggevende legt haar dus gewoon zijn wil op, die voert geen overleg Dat snap ik niet, die mensen kunnen niet naar hun eigen functioneren kijken. $1 \mathrm{k}$ heb nog gezegd, dat is natuurlijk niks voor zo'n meisje, wees voorzichtig. Dat zou hij doen.

Op advies van de verzekeringsarts heeft de vrouw met haar werkgever gesproken over aangepaste werkzaamheden. In het gesprek blijkt echter dat er niet echt sprake is geweest van overleg. De leidinggevende heeft aangegeven wat de vrouw moet doen, maar is voorbij gegaan aan het idee dat de vrouw zelf ook ideeën heeft. De verzekeringsarts heeft de werkgever daar voorafgaande aan het gesprek met de werknemer al op aangesproken. De werkgever is echter niet te motiveren voor begripvol werkgeversgedrag. De verzekeringsarts geeft de vrouw ruimte om naar een andere oplossing te zoeken.

Soms wordt de samenwerking bemoeilijkt omdat de werkgever niet op de hoogte is van wat er met de werknemer aan de hand is, en wil de werknemer ook niet dat de werkgever dat te weten komt. Het idee dat werkgevers en werknemer zelf problemen oplossen, veronderstelt een bepaalde mate van begrip aan weerszijden. Dat begrip is soms moeilijk op te brengen, met name als de werknemer de werkgever niet precies wil vertellen wat er aan de hand is. Dat komt met name voor bij mensen met psychische of psychosociale klachten. Aan deze mensen is 'aan de buitenkant' niets te zien en dat maakt het voor de werkgever soms moeilijk om begrip op te brengen. De bemiddeling van de verzekeringsgeneeskundige is dan ook niet eenvoudig, omdat die gehouden is aan een geheimhouding.

[Gedurende cen SMT bij de thuiszorg brengt een leidinggevende cen thuishulp ter sprake:]

wg: mevrouw $x$ heeft aangegeven dat ze voorzichtig weer wil beginnen. En dan eigenlijk alleen in de gezinnen waar ze werkte voor ze zich ziek meldde. $1 \mathrm{k}$ vind dat dat eigenlijk niet kan. Dat is niet verantwoord naar die mensen toe. Die mensen zijn inmiddels gewend aan een nieuwe thuishulp, en dan zouden ze nu weer om moeten schakelen. Als mevrouw weer kan werken, kan ze toch ook gewoon in andere gezinnen beginnen?

va: ik kan me de wens van mevrouw wel voorstellen. Gezien de problemen van mevrouw is het voor haar makkelijker om in haar oude gezin te beginnen, dat is vertrouwd. Voor mevrouw is het ook moeilijk, en ze komt dan in een vertrouwde omgeving. Wat voor gezin is dat precies, waar mevrouw werkte voor haar ziekmelding? Vinden die mensen het zelf vervelend als mevrouw daar nu weer terugkomt? Ik heb er met mevrouw over gesproken en zelf dacht ze dat dit gezin dat wel goed zou vinden, omdat ze altijd heel plezierig contact met deze mensen had. 
wg: eigenlijk vind ik dat we dat naar onze cliênten niet kunnen doen. We willen haar eigenlijk in een nieuw gezin plaatsen.

wg: goed, ik zal er nog eens naar kijken, misschien kan ik er nog wel een mouw aan passen en haar toch in dat gezin plaatsen.

va: goed, ik hoop dat het lukt, want dat zou voor mevrouw wel goed zijn.

(als belanghebbende later op het spreekuur komt, blijkt de thuiszorgmanager niets te hebben ondernomen; na afloop van dat gesprek zegt de verzekeringsarts dat $z e$ dat al vermoedde. De thuiszorgmanager is niet overtuigd van het feit dat de vrouw terecht verzuimt. Belanghebbende heef zeer ernstige problemen in de prive-sfeer en lijdt daar psychisch erg onder. De verzekeringsarts kan dat echter niet aan de thuiszorgmanager vertellen, omdat de vrouw in kwestie niet wil dat ze op haar werk op de hoogte zijn van har privéproblemen).

De werkgever vertrouwt het verhaal van de werknemer niet. Alhoewel de verzekeringsgeneeskundige overtuigd is van de ernst van de klachten, blijft de twijfel bij de werkgever aanwezig. De verzekeringsarts kan daar weinig aan doen, omdat de vrouw niet wil dat de werkgever weet wat er aan de hand is. De werkgever wordt niet overtuigd, om zijn verantwoordelijkheid op te moeten nemen. Hij vertrouwt niet op het oordeel van de verzekeringsarts en trekt daarmee impliciet diens deskundigheid in twijfel. De arbeidsongeschiktheid van de vrouw wordt verlengd.

In bovenstaande voorbeelden heeft de arbeidsongeschiktheid van de zieke werknemers te maken met de relatie tussen werkgevers en werknemers. Werkgevers nemen hun verantwoordelijkheid om die relatie 'gezond' te houden niet op zich. De verzekeringsartsen zijn niet in staat werkgevers te overtuigen en staan met lege handen. Werknemers in bovenstaande voorbeelden maken plausibel dat de relatie met de werkgever de werkhervatting in de weg staat. Die redelijkheid wordt, zonder dat dat relatieprobleem wordt opgelost, in zeker zin beloond. De werknemers krijgen de tijd om 'bij te komen' voordat zij weer aan het werk gaan. Uiteindelijk verliezen verzekeringsartsen in deze situaties terrein. Ze slagen er niet in om werkgever en werknemer gezamenlijk verantwoordelijk te maken voor het zoeken naar oplossingen die een werkhervatting mogelijk maken. Op korte termijn krijgt de werknemer enige ruimte, maar op lange termijn verandert er niets in de werkgever-werknemer relatie en zou de werknemer wel eens aan het kortste eind kunnen trekken.

Waar verzekeringsartsen nauwelijks overleg voeren met behandelend artsen, richten zij zich regelmatig tot werkgevers om hen aan te moedigen tot verantwoord werkgeversgedrag. Een belangrijk aspect van het accepteren van verantwoordelijkheid is, zoals we bij werknemers ook gezien hebben, dat degene die de verantwoordelijkheid op zich neemt, het idee van verantwoordelijkheid internaliseert. Het onder dwang opleggen van verplichtingen, als dat al zou kunnen, doet afbreuk aan het opnemen van verantwoordelijkheid. Enige stimulering om mensen als het ware te leren hoe ze verantwoordelijkheid kunnen vormgeven is wel mogelijk, maar als mensen dat niet vanzelfsprekend vinden (de situatie 
anders definiëren), ontstaat een patstelling. De mate waarin verzekeringsartsen er in slagen om de arbeidsongeschiktheidsbegeleiding en -beoordeling vorm te geven vanuit het idee dat het oplossen van belemmeringen ten aanzien van de werkhervatting een verantwoordelijkheid van werkgevers en werknemers is, is in sterke mate afhankelijk van het feit of ze werkgevers (en werknemers) kunnen overtuigen van die situatiedefinitie.

\section{De formele uitweg}

Zoals in de vorige hoofdstukken al aan de orde is geweest, is er een uitweg in situaties waarin probleemdefiniëring en verantwoordelijkheden door betrokkenen genegeerd worden. Verzekeringsartsen vallen dan terug op een formele aanpak. De vraag die dan centraal staat is niet meer of werknemers hun verantwoordelijkheden dragen, maar of er sprake is van ziekte. De logica van de verzekeringsgeneeskundige praktijk maakt het vanzelfsprekend dat verzekeringsartsen zich bezig houden met interventies in een werkgever-werknemer-relatic, min of meer los van de vraag of naast die fricties sprake is van ziekte (die relatie kan immers een belemmering vormen voor de werkhervatting). De vanzelfsprekendheid van het bespreken van fricties in de arbeidsrelatie in de verzekeringsgeneeskundige praktijk verdwijnt echter als de logica op andere plaatsen barsten gaat vertonen. Als werknemers en/of werkgevers hun verantwoordelijkheden niet op zich nemen, en im- of expliciet de situatiedefinitie niet onderschrijven en het verzekeringsgeneeskundige domein negeren, wordt het onmogelijk voor de verzekeringsarts om zijn zeggenschap via het beroep op verantwoordelijkheid uit te oefenen. Zoals we ook in de vorige hoofdstukken hebben gezien, resten verzekeringsartsen dan twee oplossingen. Of ze houden vast aan hun deskundigheid, maar omdat ze er niet in slagen andere betrokkenen te binden, verliezen zij hun zeggenschap. Of ze veranderen van rol. De werkgerelateerde situatiedefinitie en de daarbij behorende verantwoordelijkheden maken dan plaats voor het formele criterium van ziekte.

\footnotetext{
va: heeft u contact met het werk?

cl: ik heb de baas gebeld, volgende week ga ik koffie drinken.

va: u bent er nog niet geweest?

cl: nee, ik heb ook nog pijn in m'n heup.

va: uw werkgever denkt niet dat u nog terug komt tijdens de zwangerschap.

el: nee, het werk is te zwaar.

va: en u kunt geen andere werkzaamheden doen?

cl: nee, dat is te zwaar.

$\mathrm{Na}$ afloop geeft de verzekeringsgeneeskundige aan: het lukt niet om het hier anders te doen. Werkgever en werknemer aijn het eens.
}

De verzekeringsarts is er niet in geslaagd om het probleem zodanig te formuleren dat werkgever en werknemer gebonden worden aan het actief zoeken naar oplossingen. 
Werkgever en werknemer hanteren de zwangerschap als voldoende legitimatie om het niet werken van de vrouw te accepteren.

In geval van conflicten tussen werkgever en werknemer of spanningen op het werk, vormen die spanningen vaak de aanleiding voor werknemers om zich ziek te melden. In eerste instantie worden dat soort problemen vrij makkelijk gelabeld als overspannenheid, als de legitimatievraag op tafel komt. Als werkgevers en werknemers echter niet constructief werken aan het verbeteren van die relatie, valt voor verzekeringsartsen de legitimeringsgrond na verloop van tijd weg.

[Belanghebbende zit bijna een half jaar in de Ziektewet als gevolg van een conflict met de werkgever. De werkgever vindt hem niet geschikt als teamleider, maar de man is het daar niet mee eens. Hij heef nu een psychologische test gedaan, waaruit moet blijken of hij wel of niet geschikt is. Daarover heef hij als het goed is ook een gesprek met $z$ 'n werkgever gehad.]

va: u heeft de uitslag van de test gekregen en besproken met de werkgever, hoe is dat gegaan?

cl: de testuitslag is goed. Ik ben geschikt voor teamleider, niet autoritair, maar een democratisch leider. Volgens de psycholoog zou ik goed kunnen werken als personeelsmanager of iets dergelijks. Het gesprek met de werkgever is morgen.

va: dat gesprek moet nu wel snel gaan.

cl: ik wil ook aan de slag, ik wil het werk gaan combineren met een aanvullende opleiding. De werkgever heeft me wel aangeboden om als groepsleider terug te komen, maar gezien de uitslag van de test wil ik gewoon als teamleider terug. Tenzij er een ontwikkelingstraject uit gezet wordt en het tijdelijk onmogelijk is om dat met de functie als teamleider te combineren.

va: dat lijkt me wel redelijk, maar het moet nu wel 20 snel mogelijk geregeld worden. Heeft u nog gewerkt de afgelopen tijd?

cl: nee, ik heb wel aangeboden om administratieve werkzaamheden te doen, maar dat hebben ze afgewezen.

va: vrijdag bel ik u op over de afloop van het gesprek. Laat de werkgever maar weten dat uiterlijk over twee weken de Ziektewet stopt. Het is mu een probleem van de werkgever geworden.

$\mathrm{Na}$ afloop zegt de verzekeringsarts: dit is geen gemakkelijke werkgever, maar het is hun probleem. De spanningen die het conflict te weeg bracht waren wel even reden dat de man z'n werk niet kon doen, maar dat is nu over en de uitslag van de test is duidelijk.

De verzekeringsarts beëindigt de Ziektewet, ook al is het probleem niet opgelost. Omdat werkgever en werknemer niet constructief werken aan het oplossen van het probleem, haalt de verzekeringsarts het wettelijke criterium naar voren. $\mathrm{Er}$ is geen sprake van ziekte, dus is de werknemer niet arbeidsongeschikt. Wat werknemer en werkgever vinden is daarbij niet meer van belang. Ook als werkgevers zich eenzijdig onttrekken aan hun verantwoordelijkheid, wordt de mogelijkheid om in overleg en met wederzijdse instemming een arbeidsongeschiktheid te beëindigen afgesloten.

cl: ik wil wel graag weer met halve dagen beginnen, maar dat wil de werkgever niet. Die wil dat ik pas na de vakantie weer begin, in de nieuwe functie. 
De werkgever wil de vrouw geen aangepaste werkzaamheden laten doen. De vrouw zelf geeft aan dat ze dat wel kan. De werkgever wordt nu geconfronteerd met het formele criterium van ziekte. Ook al is de vrouw niet geschikt en zijn er belemmeringen omdat de werkgever en werknemer geen goede relatie hebben, er is geen sprake van ziekte en dus hoort het probleem niet in de spreekkamer van de verzekeringsarts thuis. De verzekeringsarts beëindigt daarmee zijn bemiddeling. Alhoewel de verzekeringsartsen in deze situatie aangeven dat het een probleem van de werkgever is, kun je je afvragen of het niet uiteindelijk de werknemer is die met een probleem blijft zitten. De 'normale' werknemer-werkgeverrelatie wordt hier hersteld, en daarin is de werknemer, zeker als er geen sprake is van een open (ideaaltypische) relatie, vaak de zwakkere partij.

Als werkgevers en/of werknemers zich onttrekken aan hun verantwoordelijkheid verschuift de arbeidsongeschiktheidsbegeleiding en -beoordeling van een werkgerelateerde definitie naar een ziekte georiënteerde definitie. De vraag die dan centraal komt te staan, is niet hoe werknemers en werkgevers hun verantwoordelijkheid kunnen vorm geven, maar of er sprake is van ziekte. Problemen die in eerste instantie werden beschouwd als belemmeringen voor de werkhervatting, worden dan kwesties die in de arbeidsrelatie opgelost moeten worden. Die horen niet in de Ziektewet, zijn geen oorzaken voor arbeidsongeschiktheid en behoren niet binnen het domein van verzekeringsartsen.

\section{Afwijken van goed werkgeverschap}

Werkgevers spelen een belangrijke rol in de verzuimbegeleiding. Ze bevinden zich door de situatiedefinitie in de verzekeringsgeneeskundige praktijk in het hart van het verzekeringsgeneeskundige domein. Waar verzekeringsartsen afhankelijk zijn van verantwoordelijke werknemers om hun domein te bewaken, zijn verantwoordelijke werknemers niets zonder verantwoordelijke werkgevers. Verantwoordelijkheid is echter geen afdwingbare opstelling. Niet alleen omdat werkgevers slechts ten dele binnen de invloedssfeer van verzekeringsartsen opereren, maar ook omdat dwang verantwoordelijkheid ondergraaft.

Meer dan bij behandelend artsen activeren verzekeringsartsen de institutionele inbedding waarin de arbeidsongeschiktheidsbegeleiding en -beoordeling plaats vindt. Werkgevers en werknemers maken afspraken waarop niet alleen werknemers, maar ook werkgevers kunnen worden aangesproken. Alhoewel werkgevers ook op basis van een verzuimbeleid en -protocol niet gedwongen kunnen worden om mee te werken, zijn werkgevers door de afspraken die daarin zijn opgenomen gecommitteerd, hetgeen het mogelijk maakt ze aan te spreken op niet-constructief gedrag. Het binden van werkgevers aan hun verantwoordelijkheden kent echter evenals bij andere betrokkenen haar grenzen. Werkgevers die zich aan hun verantwoordelijkheid onttrekken, bemoeilijken het werk van verzekeringsartsen omdat cliënten hun verantwoordelijkheid als werknemer niet volledig op zich 
kunnen nemen. De arbeidsongeschiktheidsbegeleiding stokt dan. Voor werkgevers is het aanzienlijk gemakkelijker dan voor werknemers zich aan hun door de verzekeringsarts gedefinieerde verantwoordelijkheid te onttrekken, omdat verzekeringsartsen bij werkgevers geen enkele sanctie mogelijkheid hebben. Verantwoordelijke werknemers worden desalniettemin in zekere zin voor hun opstelling beloond, door ze tijd te geven om zich op te laden voordat ze hun werk hervatten. Dat is echter slechts tijdelijk. Als conflicten of spanningen tussen werkgever en werknemer niet binnen de werkgever-werknemer relatie worden besproken, met andere woorden als werkgever en werknemer er niet toe komen hun verantwoordelijkheid op te nemen, verandert de verzekeringsarts van vertoog. De vraag die dan centraal komt te staan is of er sprake is van ziekte. Is de ziekmelding van de werknemer in diens eigen perspectief veroorzaakt door de conflicten of problemen op het werk, dan is die vraag snel beantwoord. Lopen gezondheidsklachten en problemen tussen werkgever en werknemer meer door elkaar, dan wordt voor beëindiging van de Ziektewet, zoals in het vorige hoofdstuk uiteen is gezet, de stem van de behandelend arts van belang. Beëindiging van de Ziektewet herstelt de 'normale' werkgever-werknemer relatie. Als die relatie slecht is (conflicten etc.), is de werknemer overgeleverd aan zijn werkgever. De machtsrelatie, die verzekeringsartsen in hun bemiddeling en stimulering min of meer lijken te negeren of proberen te corrigeren, kan dan weer gewoon haar werk doen.

\section{Conclusie}

In dit hoofdstuk is de constructie van de rol en verantwoordelijkheid van werkgevers bij de arbeidsongeschiktheidsbegeleiding en -beoordeling aan de orde geweest. Die rol van werkgevers hangt nauw samen met de constructie van cliënten als werknemers en de definiëring van arbeidsongeschiktheid als probleem ten aanzien van de werkhervatting. Het feit dat werknemers voor een belangrijk deel zelf oplossingen aan moeten dragen voor hun problemen, maakt werkgevers betrokken. Van werkgevers wordt verwacht dat zij met werknemers overleggen over werkaanpassingen en zoeken naar mogelijkheden om de werkhervatting gestalte te geven. De consequentie van die verantwoordelijkheidstoewijzing is dat werkgevers en werknemers de facto stem hebben bij de vaststelling van arbeidsongeschiktheid.

De werkgeversverantwoordelijkheid reikt verder dan het organisatorisch mogelijk maken van een werkhervatting. Willen werknemers hun verantwoordelijkheid kunnen dragen, dan is het niet alleen van belang dat ze taken uitvoeren. Om aanpassingen te realiseren is een goed functionerende werknemer-werkgever relatie van belang. Onder goed functioneren wordt dan verstaan een open relatie, waarin enerzijds ruimte is om problemen en fricties te bespreken en anderzijds een zakelijk karakter, waarbinnen werk- 
gevers en werknemers elkaar kunnen aanspreken op verantwoord gedrag. Een dergelijke relatie vormt als het ware een voorwaarde om de verantwoordelijkheid voor het zoeken naar praktische oplossingen naar de werknemer-werkgever relatie te kunnen delegeren.

De rol van werkgevers in dit samenspel is, afhankelijk van de situatie, begeleider van het bemiddelingstraject of 'assistent' van de verzekeringsartsen. Door middel van begrip en openheid kunnen werkgevers een werknemer ondersteunen bij het hervatten van het werk. Anderzijds doen werkgevers, evenals verzekeringsartsen, door werknemers ter verantwoording te roepen, een beroep op het werknemer zijn van de werknemer.

Werkgevers en werknemers worden in de verzekeringsgeneeskundige praktijk op vergelijkbare manier en met vergelijkbare middelen aangesproken op hun verantwoordelijkheid. In deze wijze van aanspreken wordt een open werkgever-werknemerrelatie geconstrueerd. Dat open karakter veronderstelt een gelijkwaardigheid. Alhoewel er ongetwijfeld situaties zijn waarin de werknemer-werkgeverrelatie dat karakter draagt, is die relatie dat lang niet altijd. In gevallen waarin de werkgever niet erg genegen is om mee te werken aan cen open arbeidsrelatie wordt de bemiddelingspositie van de verzekeringsarts moeilijk. Het op formele gronden beëindigen van de Ziektewet, brengt problemen tussen werknemer en werkgever terug in de arbeidsrelatie. De vraag is of dat in de praktijk niet betekent dat het een probleem van de werknemer wordt.

Met het delegeren van verantwoordelijkheden worden verzekeringsartsen afhankelijk van de medewerking van werkgevers, maar komt tevens een 'nieuw' aspect van hun deskundigheid naar voren. Meer dan deskundig op het terrein van de klachten van zieke werknemers en de belemmeringen die daar mee samenhangen, zijn verzekeringsartsen bekwaam in het stimuleren van een goede werknemer-werkgever relatie. Dat stimuleren lijkt een taak op zich te worden. Binnen een goede werknemer-werkgever relatie, lossen werknemers en werkgevers immers het arbeidsongeschiktheidsprobleem op. Is die relatie open en nemen beiden hun verantwoordelijkheid, dan onthoudt de verzekeringsarts zich van een oordeel.

Tot op bepaalde hoogte is het voor verzekeringsartsen mogelijk om werkgevers te binden aan hun rol. Afspraken in het kader van een verzuimbeleid, maar ook afspraken die werknemers en werkgevers individueel maken, scheppen een kader om dat te doen. Lang niet altijd is een dergelijk kader aanwezig (sommige werkgevers hebben geen verzuimbeleid of SMT). Maar ook als dat wel het geval is, blijven verzekeringsartsen afhankelijk van de goodwill van werkgevers. Waar verantwoordelijkheid op zich nemen bij werknemers betekent dat zij normen ten aanzien van verantwoordelijk gedrag overnemen, geldt dat ook ten aanzien van werkgevers. Dwang uitoefenen doet het opnemen van verantwoordelijkheid te niet. Het beëindigen van de Ziektewet met behulp van formele argumenten, is dan ook een soort laatste redmiddel, dat tevens een echec karakter heeft. 


\section{Noten}

1. Arbeidsconsulenten nemen binnen de logica van de verzekeringsgeneeskundige praktijk een eigen positie in. Interessant zou zijn om hun werk en bijdrage in het proces van verantwoordelijkheidstoewijzing nader te analyseren. In deze studie worden ze echter als verlengde arm van de verzekeringsarts beschouwd.

2. Hierdoor lijkt het wellicht dat de rol van werkgevers een afgeleide vormt van die andere onderdelen. Dat is echter een product van het boek, de definitie van de rol van werkgevers komt in samenhang met die andere onderdelen tot stand, en is even zeer bepalend voot die andere onderdelen als dat ze er door bepaald wordt. 



\section{Conclusie}

\section{Inleiding}

De betrokkenheid van artsen bij de uitvoering van de arbeidsongeschiktheidsregelingen wordt gelegitimeerd door hun medische expertise. Recent onderzoek naar de wijze waarop artsen deze regelingen uitvoeren en discussies binnen de medische beroepsgroep werpen echter de vraag op, of de controle en begeleidingswerkzaamheden van artsen in de praktijk inderdaad vooral gebaseerd zijn op expertise op het gebied van ziekte en gezondheid. In dit onderzoek stond daarom de vraag centraal hoe verzekeringsartsen hun taak in de dagelijkse praktijk vormgeven. Uitgangspunt daarbij was dat inzicht in dat praktisch handelen verkregen kan worden door de logica van de praktijk in kaart te brengen. Om de logica van een praktijk in kaart te brengen, is het noodzakelijk om de diepte in te gaan. Om pragmatische redenen is daarom gekozen een specifieke 'poortwachterspraktijk' te analyseren, namelijk de uitvoering van de ziektewet bij een van de toen in nederland opererende bedrijfsverenigingen. Een aantal artsen, die in hun dagelijkse praktijk werken aan de hand van de zogenaamde argumentatieve claimbeoordeling, is daartoe gevolgd. In dit laatste hoofdstuk zal ik de logica van de verzekeringsgeneeskundige praktijk kort resumeren. Vervolgens ga ik in op de vraag wat de waarde is van het doen van onderzoek naar praktisch handelen aan de hand van het concept logica. Daarna zal ik de normatieve dimensies van dit praktisch handelen exploreren, om tenslotte op basis van de in dit onderzoek opgedane inzichten een blik op recente wijzigingen in het veld van de arbeidsongeschiktheidsregelingen te werpen.

\section{De logica van de verzekeringsgeneeskundige praktijk}

De uitvoeringspraktijk van de ziektewet kent haar legitimering in een wettelijk kader. Dat betekent echter niet dat die wet- en regelgeving de ordening van die uitvoeringspraktijk bepalen of verklaren. Die uitvoeringspraktijk kent, net als andere praktijken, een eigen dynamiek en logica, die wel verband houdt met wet- en regelgeving maar daar niet toe is te herleiden (Van der Veen, 1990, 1997).

Het analyseren van de verzekeringsgeneeskundige praktijk als een praktijk met een eigen logica, maakt het mogelijk om de rationaliteit of ordening van die praktijk in andere termen te beschrijven, dan in het standaardbeeld gebruikelijk. In het onderstaande zal ik die consequenties voor de beschrijving van de verzekeringsgeneeskundige praktijk 
nog eens de revue laten passeren. Daarbij ga ik in op de vraag wat die praktische rationaliteit in de verzekeringsgeneeskundige praktijk behelst; hoe in samenhang met die praktische rationaliteit betrokkenen specifieke identiteiten krijgen; en hoe binnen die praktische rationaliteit specifieke interactionele verhoudingen geconstitueerd worden, die die praktijk tot een werkbaar geheel maken.

Inzicht in het functioneren van de uitvoeringspraktijk kan verkregen worden door haar op te vatten als een handelingspraktijk. Dat functioneren kenmerkt zich niet door een formele rationaliteit, maar door een praktische rationaliteit. De orde in die praktijk is een resultante van de wijze waarop mensen hun handelen op elkaar afstemmen. Dat onderling afstemmen van handelingen is niet zozeer een bewuste of cognitieve aangelegenheid, maar een sociale aangelegenheid (Widdershoven, 1987). Een weten 'hoe te handelen' zonder dat betrokkenen volledig kunnen expliciteren waarom ze zo handelen. Door de wijze waarop mensen handelen en spreken, het beroep dat ze daarbij doen op vanzelfsprekendheden wordt een orde gecreëerd, een regelmaat in de manier van omgaan met elkaar, in de manier van praten en problemen oplossen die in het dagelijkse omgang vanzelfsprekend is en die daardoor robuustheid kent.

In tegenstelling tot wat we op basis van de formele legitimering van deze praktijk zouden veronderstellen kenmerkt die praktische ordening zich niet door het uitspraken doen of oordelen vellen over door ziekte veroorzaakte arbeidsongeschiktheid. In de verzekeringsgeneeskundige praktijk gaat het om de vraag hoe belemmeringen die mensen ondervinden bij het uitvoeren van hun werkzaamheden opgelost kunnen worden. Die activiteit kenmerkt zich door het spreken over werk en toekomst, door maken van plannen en het bedenken van oplossingen, door het activeren van cliënten om de verantwoordelijkheid voor hun eigen situatie op zich te nemen.

De 'ratio' of het patroon van die activiteit heeft niet het karakter van oordelen vellen op basis van het inventariseren van een situatie (toestand van de cliënt) om vervolgens een conclusie te kunnen trekken. De vraag of iemand op basis van zijn toestand al dan niet arbeidsongeschikt is, is niet de centrale vraag die op het spel staat. De vraag die centraal staat is hoe mensen hun werk weer kunnen hervatten. Het gesprek tussen verzekeringsartsen en cliënten is een proces, waarin cliënten gestimuleerd en geactiveerd worden geheel of gedeeltelijk weer aan het werk te gaan. Arbeidsongeschiktheid, in de formele betekenis van niet kunnen werken vanwege ziekte, is in dit proces geen toestand die wordt vastgesteld. Er wordt hooguit aangeven dat mensen die hun werk niet of slechts gedeeltelijk hebben hervat arbeidsongeschikt zijn, omdat ze geheel of gedeeltelijk een beroep doen op de ziektewet. Of en in hoeverre dat niet werken oorzakelijk verband houdt met hun ziekte is geen ijkpunt in het proces en in die betekenis bestaat arbeidsongeschiktheid dus niet'. De formele definitie van arbeidsongeschiktheid, als niet kunnen werken wegens ziekte, speelt alleen een rol in gevallen waarin het proces van stimulering 
en activering niet loopt en verzekeringsartsen vervolgens een beroep doen op de wet om het ziekteverzuim te beëindigen.

In samenhang met de organisatie of ordening van de verzekeringsgeneeskundige praktijk rondom de vraag hoe iemand zijn werkzaamheden weer kan hervatten komen bepaalde identiteiten van de betrokken actoren tot stand. Ook de identiteit van betrokkenen is niet vooraf gegeven, maar krijgt in het handelen vorm. 'What is signified as an identity is not signified as a given point in time after which it is simply there as an inert piece of entitative language. Identity is practiced. The pervasive and mundane acts in which this is done make people what they are' (Mol, 1999, blz.27). Identiteit is dan 'het geheel van gewoonten, praktijken en instituties dat richting geeft aan het handelen en in het handelen gestalte krijgt' (Widdershoven, 1987, 44). Dat betekent niet dat mensen geen identiteit hebben voorafgaande aan de interactic, maar dat spreken over identiteit geen betekenis heeft zonder haar te benoemen aan de hand van de specifieke gestalte die ze krijgt in de interactie.

De deelnemers aan de interactie, verzekeringsartsen en cliënten, krijgen in die interactie een specifieke identiteit. Die identiteit komt niet overeen met de posities van beide partijen zoals in het standaardbeeld verondersteld wordt. Zoals voorstanders van het model van de argumentatieve claimbeoordeling al betogen, neemt de cliënt geen object maar een subject positie in. In tegenstelling tot de veronderstellingen in het argumentatieve claimbeoordelingsmodel, is die subject positie echter niet vooraf gegeven. In de interactie doet de cliënt geen verslag van zijn of haar toestand in een kant en klare taal, maar in het gesprek wordt door de wijze van vragen stellen en in samenhang met de centrale probleemdefinitie een werknemer geconstrueerd. Met andere woorden wat het probleem is, wie daar verantwoordelijkheid voor draagt en welke activiteiten daarin besloten liggen, krijgt gedurende de interactie vorm.

De constructie van werknemers met een eigen verantwoordelijkheid geeft ook aan verzekeringsartsen een andere positie dan in het standaardbeeld is verondersteld. De verzekeringsarts is niet zozeer beoordelaar of beslisser, maar stimulator. Niet zijn expertise op het gebied van ziekte, die de legitimatie vormt van zijn aanwezigheid bij de verzuimbegeleiding en -controle, maar zijn bekwaamheid in het motiveren van cliënten om hun eigen verantwoordelijkheid op zich te nemen vormt zijn identiteit. Niet externe dwang, maar internalisering van controle door werknemers staat voorop.

Die verzekeringsgeneeskundige identiteit is in het licht van de formele legitimering van zijn positie merkwaardig. Die legitimering is namelijk gelegen in zijn professionele expertise op het terrein van ziekte. In dit onderzoek is echter duidelijk geworden dat verzekeringsartsen een eigen domein definiëren, dat niet in de lijn ligt van wat normaal gesproken onder medische expertise wordt verstaan ${ }^{2}$. Dat heeft te maken met de verhouding tussen behandelend artsen en therapeuten enerzijds en verzekeringsartsen anderzijds. Ontwikkelen van professioneel handelen via de 'ziektelijn', is ingewikkeld, omdat deze 
twee typen artsen dan in elkaars vaarwater komen. Met een nieuwe deskundigheidsdefinitie in de hand ontstaat ruimte om in ieder geval ten opzichte van de cliënt een eigen zeggenschapsdomein te creễren. Het construeren van twee problemen en twee trajecten maakt het mogelijk om naast, in plaats van onder in de hiërarchie te staan, ook al blijft in debatten binnen de professie de positie van verzekeringsartsen ondergeschikt.

Maar de constructie van identiteiten beperkt zich niet tot de direct aanwezige betrokkenen alleen. In de interactie tussen verzekeringsartsen en cliënten worden eveneens andere betrokkenen, zoals behandelend artsen en werkgevers, gepositioneerd. Die positie of constructie dient als handelingsoriēntatie van verzekeringsartsen en cliënten, en vormt geen representatie van de positie van behandelend artsen in positivistische zin'. Verzekeringsartsen hebben in hun spreekkamer niet de macht/positie om voor te schrijven wat behandelend artsen doen. Waar verzekeringsartsen echter wel in kunnen slagen is binnen de spreekkamer cliënten te binden aan hun definiëring van het onderscheid tussen hun eigen taken en taken van behandelend artsen. Dat onderscheid definiëren ze in de spreekkamer op andere wijze dan dat het gestalte krijgt in formele regelingen. In die formele regelingen gaat het vooral om uitwisseling van informatie tussen behandelend artsen en verzekeringsartsen. Daarin is vrij strikt vastgelegd welke informatie overgedragen mag worden. In de praktijk zien we echter dat dit uitwisselen van informatie niet zozeer gericht is op 'een beeld krijgen van de toestand van de cliënt', al dan niet in strikt medische zin, maar dat contacten met de behandelende sector een rol spelen in de mate waarin verzekeringsartsen cliënten en eventueel derden kunnen overtuigen van de redelijkheid van hun voorstel voor een werkhervatting. De 'informatie' van behandelend artsen wordt pas relevant als er problemen ontstaan of als de arbeidsongeschiktheid langdurig wordt. Die informatie geldt in het eerste geval ter legitimering van een arbeidsgeschiktheidsverklaring ten opzichte van cliënten. In het tweede geval is die informatie nodig voor legitimering ten opzichte van derden. De probleemdefiniëring in de verzekeringsgeneeskundige praktijk en de handelwijze via zelf-controle, omzeilt in normale gevallen het probleem van gegevensuitwisseling. Door de arbeidsongeschiktheid los te koppelen van (objectieve) ziekte, is die informatie niet nodig voor de werkzaamheden. Tegelijkertijd kan het 'middel' informatie opvragen een rol spelen om uit een patstelling met een cliënt te komen.

Waar de probleemdefiniëring in de verzekeringsgeneeskundige praktijk het verzekeringsgeneeskundige domein onafhankelijk makt van het domein van behandelend artsen, en het mogelijk wordt om de invloed van behandelend artsen op de arbeidsongeschiktheidsbegeleiding te neutraliseren, worden verzekeringsartsen tegelijkertijd meer afhankelijk van werknemers en werkgevers en hun onderlinge relatie. In de verzekeringsgeneeskundige logica worden beiden 'patiënt', in die zin dat de interventies van verzekeringsartsen zich niet alleen richten op werknemers, maar evenzeer op werkgevers. In de wijze waarop werkgevers en werknemers gestimuleerd worden zien we overeenkomsten. De 
subjectvorming van beiden komt tot stand door middel van het wijzen op en delegeren van verantwoordelijkheid. Zowel werknemers als werkgevers moeten plausibele argumenten aanvoeren, plannen ontwikkelen en zich aan afspraken houden. Beide partijen zijn verantwoordelijk voor het creëren of in stand houden van een open arbeidsrelatic.

De probleemdefiniëring en de constructie van identiteiten, zowel die van werknemers en verzekeringsartsen zelf als die van behandelend artsen en werkgevers, komen in onderlinge wisselwerking tot stand. In de praktijk zien we een precair evenwicht ontstaan, waarbinnen het mogelijk wordt om de arbeidsongeschiktheidsbegeleiding en beoordeling vorm te geven. Precair in de zin dat er voortdurend werk moet worden verzet om de handelingen van alle actoren op elkaar af te stemmen. Zowel cliënten, al dan niet gesteund door behandelend artsen of therapeuten, als werkgevers kunnen zich onttrekken aan de in de verzekeringsgeneeskundige praktijk gedefinieerde aanspraken op verantwoordelijkheid. Die precaire balans wordt versterkt door mogelijke bondgenoten buiten het 'primaire' circuit van betrokkenen, zoals bijvoorbeeld commissies van beroep. waar de arbeidsongeschiktheidsbegeleiding en -beoordeling lang niet altijd beoordeeld op grond van de vraag of er daadwerkelijke belemmeringen zijn voor de werkhervatting. Maar ook verzekeringsartsen zelf zijn evenzeer speelbal als speler in het geheel. Ook de speelruimte van verzekeringsartsen is beperkt. Binnen de logica van de praktijk wordt immers duidelijk dat ook verzekeringsartsen zelf onderworpen zijn aan het verantwoordelijkheidsvertoog. De mogelijkheid om een machtswoord uit te spreken mag formeel niet op bezwaren stuiten, in de praktijk is ze begrensd. Het machtswoord is eerder een zwaktebod, waarmee de grenzen van het onderhandelingsspel zichtbaar worden en dat uiteindelijk weinig lijkt bij te dragen aan de activering en motivering van zieke werknemers om deel te blijven nemen aan het arbeidsproces.

De logica van de verzekeringsgeneeskundige praktijk of de dynamiek van de uitvoering heeft het karakter van een onderhandeling waarbinnen betrokkenen actoren hun handelen op elkaar afstemmen. Die afstemming vindt plaats rondom de activiteiten die ondernomen moeten worden om een werkhervatting gestalte te geven. Die probleemstelling creëert een afstand tussen de verzekeringsgeneeskundige praktijk en de curatief gerichte geneeskundige praktijk, en brengt werkgevers en werknemers in het hart van het verzekeringsgeneeskundig domein. Dat betekent dat behandelend artsen een positie van buitenstaander krijgen, zonder verantwoordelijkheden ten aanzien van de arbeidsongeschiktheidsbegeleiding en -beoordeling, en werknemers en werkgevers een centrale positie innemen, met grote verantwoordelijkheid voor de arbeidsongeschiktheidsbegeleiding. Wat die verantwoordelijkheid precies inhoud krijgt tijdens de onderhandeling vorm. De rol van verzekeringsartsen in dit geheel is niet zozeer controlerend van aard, als wel het activeren of motiveren van werknemers en werkgevers tot het dragen van verantwoordelijkheid en het stimuleren van zelf-controle. 
De logica van de verzekeringsgeneeskundige praktijk heeft een eigen dynamiek, die afwijkt van datgene dat in het standaardbeeld wordt verondersteld. Die eigen dynamiek kent een bepaalde robuustheid, maar is tegelijkertijd precair. Dat hangt samen met het feit dat gegeven het complexe onderhandelingsproces weinig andere wegen openstaan om het proces vorm te geven, zonder dat die wegen op grenzen stuiten.

\section{Logica's van praktijken}

In het eerste hoofdstuk van dit proefschrift heb ik voorgesteld om de verzekeringsgeneeskundige praktijk te onderzoeken met behulp van het concept 'logica'. Op theoretische gronden heb ik beargumenteerd dat het werken met dit concept een meerwaarde heeft ten opzichte van analyses die dat praktisch handelen tegemoet treden aan de hand van het concept 'besluitvorming'. Beide concepten, logica en besluitvorming, geven een algemeen format of beeld van het soort activiteit dat in de spreekkamer plaats vindt. Het concept 'besluitvorming' heeft een formele connotatie. Om een besluit te nemen wordt een toestand of situatie in kaart gebracht, en wordt door een beoordelaar aan de hand van criteria afgewogen in welke categorie de situatie thuis hoort. In het kader van het thema van dit boek gaat het dan over de toestand of situatie van de cliënt die al dan niet in de categorie arbeidsongeschikt wordt geplaatst. Een analyse van de praktijk draait dan enerzijds om de vraag welke aspecten van de situatie in kaart worden gebracht en anderzijds om de vraag welke criteria worden gehanteerd om iemand te categoriseren. Deze aspecten worden geanalyseerd in het licht van de uiteindelijke conclusie die getrokken wordt door de beslisser, in casu de verzekeringsarts. Het concept logica biedt de mogelijkheid om het praktisch handelen in zekere zin opener tegemoet te treden. De focus van de analyse is gericht op het proces waarin interactiepartners voortdurend op elkaar reageren. Waar het doel van die interactie bij een analyse in termen van besluitvorming al vast ligt, namelijk het nemen van een besluit, wordt in een analyse met behulp van het concept logica dat formele doel tussen haakjes gezet. De wijze waarop de interactiepartners hun handelingen op elkaar afstemmen hoeft niet noodzakelijkerwijs gericht te zijn op de formele doelstelling van de gesprekken die verzekeringsartsen en cliënten voeren. Het doel van de interactie wordt, evenals de identiteit van betrokkenen en de betekenis van arbeidsongeschiktheid, tijdens die interactie door de interactiepartners geproduceerd. Welk doel dat is, of eigenlijk de wijze waarop interactiepartners zich op elkaar oriënteren, vormt onderdeel van de vraag en de analyse.

De analyse in dit proefschrift laat zien dat het hanteren van een dergelijk concept andere resultaten oplevert dan het werken met het concept besluitvorming. Alhoewel bijvoorbeeld Van der Veen (1990) en Mudde (1995) in hun onderzoek de formele connotatie van het concept 'besluitvorming' afzwakken door de onderhandeling centraal te 
stellen, wordt in de conclusies van deze onderzoeken dat basisidee wel terug gehaald. Artsen of arbeidsdeskundigen wegen meer zaken mee dan alleen de ziekte (inventariseren ook andere aspecten van de situatie) en hanteren aanvullende criteria om die situatie te beoordelen. De onderhandeling wordt in het licht gesteld van het besluit dat uiteindelijk genomen wordt. Daarbij maakt Mudde onderscheid tussen enerzijds medisch georienteerde normen en sociaal-normatieve normen. Alhoewel hij betoogt dat sociaal-normatieve oordelen noodzakelijk zijn om oordelen te vellen, kan dit analytische onderscheid een ongemakkelijk gevoel op bij de lezer oproepen. Door sociaal-normatieve oordelen te onderscheiden van medische wordt op z'n minst de theoretische mogelijkheid open gehouden dat die sociaal-normatieve oordelen onafhankelijk van de medische tot stand komen en wellicht dus eigenlijk beter achterwege zouden kunnen blijven.

De sociaal-normatieve dimensie van de oordelen die Mudde in hun onderzoek benoemen hebben betrekking op gedragingen van de cliënt. Ook Van der Veen gaat in op de rol die gedragingen van de cliềnt spelen bij de arbeidsongeschiktheidsbeoordeling. Ze gaan over de mate waarin cliënten herstelgedrag vertonen, zich als verantwoordelijke werknemers gedragen etc. Ook in voorliggend onderzoek is duidelijk dat dergelijke gedragingen van cliënten in de gesprekken een rol spelen. Die rol is echter in zeker opzicht anders dan de rol die Mudde en Van der Veen er aan toeschrijven. Door het hanteren van het concept logica is duidelijk geworden dat de centrale activiteit in de spreekkamer niet zozeer gericht is op beoordelen, maar zich concentreert op de vraag 'wat te doen'. In tegenstelling tot wat vaak gedacht wordt gaat het 'inventariseren' van een toestand daar niet aan vooraf, maar worden de vragen naar 'wat te doen' en 'wat is er aan de hand' gelijktijdig beantwoord. De activiteiten hebben de vorm van een traject waarin zowel het antwoord op de vraag naar 'wat te doen' als het antwoord op de vraag 'wat is er aan de hand' voortdurend tegelijkertijd maar ook slechts gefragmenteerd beantwoord worden. Waar die activiteit gericht is op het hervatten van het werk door de werknemer is de mate waarin daarin acties worden ondernomen of plannen worden gemaakt (het antwoord op de vraag 'wat te doen') tegelijkertijd een antwoord op de vraag 'wat is er aan de hand'. De vraag wat is er aan de hand is niet een vraag die verwijst naar het vaststellen van de feiten in het licht van de uitkomst, maar verwijst naar steeds verschuivende elementen in de situatie. Vanuit de vraag 'wat te doen' vervaagd het onderscheid tussen medisch-technische en sociaal-normatieve aspecten. Met andere woorden de gedragingen van de werknemer zijn indicatoren of symptomen van diens toestand. De mate waarin werknemers zich in de ogen van verzekeringsartsen verantwoord gedragen, zegt iets over het feit of zij ziek of arbeidsongeschikt zijn. Het vaststellen van ziekte, of het definiëren van de situatie van de patiënt bestaat niet uit een medisch en een sociaal-normatief deel, gedragingen en ziekte of arbeidsongeschiktheid zijn twee kanten van dezelfde medaille. Een analyse van de praktijk met behulp van het concept 'logica' laat zien dat de activiteit in de spreekkamer niet zozeer gericht is op het 
nemen van besluiten, als wel op het ondernemen van activiteiten. De praktische rationaliteit oriënteert zich op (bijbrengen van) verantwoordelijkheid en niet op de formeel gedefinieerde taakstelling vaststellen van al dan niet arbeidsongeschiktheid.

Het tamelijk open karakter van het concept logica maakt het mogelijk om het eigenstandige karakter van de praktische rationaliteit inzichtelijk te maken. Naast het open karakter hangt dat tevens samen met het abstractieniveau waarop patronen en regelmatigheden worden gezocht. Die patronen liggen op het niveau van de constructie van identiteiten van betrokken actoren en niet op het niveau van de letterlijke opeenvolging van uitingen, waar ze bijvoorbeeld in de conversatie-analyse worden gelokaliseerd. De logica van de verzekeringsgeneeskundige praktijk, zoals die in dit onderzoek is geanalyseerd, is tamelijk éénvormig. Dat betekent uiteraard niet dat alle gesprekken die deze artsen voeren identiek zijn. Er zijn wel degelijk verschillen in de wijze waarop verschillende verzekeringsartsen gesprekken voeren en ook tussen de gesprekken die één verzekeringsarts met verschillende cliënten voert. Om het patroon te zoeken zijn overeenkomsten naar voren gehaald en verschillen naar de achtergrond verschoven. De gespreksfragmenten vormen specifieke uitdrukkingsvormen van het algemene patroon. In de praktijk doen sommige artsen dat wellicht systematischer en consequenter dan andere of wijken artsen op incidentele momenten wellicht om particuliere redenen af van het algemene patroon, maar dat doet niet onmiddellijk afbreuk aan het feit dat daarmee het activeren via het stimuleren van een zelf-controle een mechanisme is dat in de praktijk werkzaam is. Ongetwijfeld kan het interessant zijn om die verschillende uitingsvormen van het algemene patroon te onderzoeken, dat maakt het opsporen van het patroon echter niet minder interessant.

Verschillen en patronen zijn in dat opzicht geen oppositionele uitersten. Praktisch handelen is niet totaal toevallig, maar kent een bepaalde robuustheid door de wijze waarop ze is ingebed in de context. Het benoemen van de logica maakt het mogelijk om te reflecteren op de vraag welke variaties waarschijnlijk zullen optreden en waar de begrenzing daarvan ligt. Bovendien maakt het signaleren van dergelijke mechanismen het enerzijds mogelijk om te reflecteren op de vraag hoe oordelen op andere locaties plaats zullen hebben en anderzijds om een afweging te maken tussen typen interventies die gepleegd zouden kunnen worden om die praktijk eventueel te veranderen.

In het boek is duidelijk geworden dat het type activiteit dat in die verzekeringsgeneeskundige praktijk wordt ondernomen drastisch afwijkt van de voorstelling die daarvan leeft in het standaardbeeld. Ik heb bijvoorbeeld laten zien hoe verzekeringsartsen op verschillende manieren cliënten proberen te binden aan het opnemen van verantwoordelijkheid. De vraag is in hoeverre de logica of dit type mechanismen ook in andere dan de onderzochte verzekeringsgeneeskundige praktijken aanwezig is. Alhoewel we daarover op basis van dit onderzoek slechts kunnen speculeren, lijkt dit niet onaannemelijk. Op de eerste plaats blijkt het mogelijk om het handelen van de zes artsen, die op verschillende 
plaatsen werken in één patroon te typeren. Bovendien blijkt ook uit ander onderzoek naar de verzekeringsgeneeskundige praktijk dat de mate waarin cliênten zich 'verantwoordelijk' gedragen een rol speelt in de arbeidsongeschiktheidsbeoordeling en -begeleiding (zie HI). Mudde laat in zijn onderzoek het GAK en het SFB bijvoorbeeld zien dat verantwoordelijkheid een grote rol speelt bij de arbeidsongeschiktheidsbegeleiding en -beoordeling. De plaats die hij aan deze noties geeft is anders dan de plaats die ze in dit onderzoek krijgen. Het lijkt echter, op grond van het voorafgaande, aannemelijker dat deze verschillen het gevolg zijn van de wijze waarop de analyse is uitgevoerd, dan dat de verzekeringsgeneeskundige praktijk binnen het SFB en het GAK een andere is dan die binnen de BVG.

De eigen verantwoordelijkheid van patiënten en cliënten staat bovendien niet alleen in de verzekeringsgeneeskundige praktijk, maar ook in hulpverleningspraktijken in het algemeen centraal (Silverman, 1989; Lupton, 1995; Süssgen, 1997; Van Loenen, 1997). Rose (1996) wijst in dit verband op de psychologisering van hulpverleningspraktijken in de Westerse samenleving. De specifieke vormgeving van de eigen verantwoordelijkheid is echter in al deze praktijken verschillend. Dat maakt het interessant om onderzoek te doen naar de wijze waarop een notie als 'eigen verantwoordelijkheid' in specifieke praktijken vorm krijgt en welke mogelijkheden en beperkingen dat oplevert voor de actoren (cliënten, maar ook hulpverleners) die in die praktijk opereren. De consequenties van het stimuleren van verantwoordelijkheid voor patiënten/cliënten zouden, gezien het verschil in karakter van hulpverlenerspraktijken enerzijds en de verzekeringsgeneeskundige praktijk, waar naast hulp (begeleiding) ook een controle-element aanwezig is, wel eens anders kunnen zijn. Ook vergelijkend onderzoek naar de verzekeringsgeneeskundige praktijk in het kader van de WAO is daarbij interessant. Onderzoek naar deze praktijk laat eveneens zien dat verantwoordelijkheid een rol speelt (Van der Veen, 1990). In tegenstelling tot de ziektewetpraktijk, kent de arbeidsongeschiktheidsbeoordeling in het kader van de WAO meer een moment-karakter en eindigen deze gesprekken meer expliciet met een oordeel. Noties van verantwoordelijkheid zouden in deze praktijk dan ook wel eens andere effecten op de interactiepartners kunnen hebben dan in de ziektewetpraktijk. Dat maakt het des te interessanter om met een open concept naar deze praktijk te kijken. Verder onderzoek is hiervoor noodzakelijk.

\section{Normativiteit van praktijken}

Onderzoek naar de logica van de verzekeringsgeneeskundige praktijk laat zien dat de rationale van het praktisch handelen in die praktijk zich onttrekt aan de formele basis daarvan, zoals die in regelgeving is vormgegeven. Dat betekent dat die praktijk een eigen normativiteit kent. In de betekenis van het in zich dragen van normen en waarden; im- of 
expliciet draagt de verzekeringsgeneeskundige praktijk normen in zich ten aanzien van de vraag hoe op een 'goede' manier met arbeidsongeschiktheid omgegaan dient te worden. En in samenhang daarmee is de verzekeringsgeneeskundige praktijk normatief in de betekenis van 'normaliseren'; het maken van onderscheidingen tussen cliënten die zich wel en cliënten die zich niet volgens de normen gedragen, tussen mensen die zich 'normaal' gedragen en mensen die afwijken.

Zeker in het domein van de sociale zekerheid, waar het draait om normatieve kwesties als rechtvaardigheid en gelijkheid, is het van belang na te gaan hoe de normativiteit van de praktijk precies werkt en welke consequenties zij heeft. Om te begrijpen hoe die normatieve dimensie van de praktijk werkt, is het van belang haar in samenhang met de praktische rationaliteit te bekijken.

In onderstaande zal ik op twee dimensies van de normativiteit van de verzekeringsgeneeskundige praktijk reflecteren. In eerste punt dat aandacht behoeft is de vraag wat de verzekeringsgeneeskundige praktijk maatschappelijk gezien 'aflevert'. Wat is het product van de activiteiten in de verzekeringsgeneeskundige spreekkamer en welke normen liggen daarin besloten. Vervolgens zal aan de orde komen welke consequenties die handelingsrationaliteit en de impliciete normen die daarin besloten liggen hebben voor de behandeling van individuele cliënten, in de spreekkamer zelf, maar meer nog op langere termijn.

De centrale activiteit binnen de verzekeringsgeneeskundige praktijk is het stimuleren, motiveren en activeren van cliënten om weer aan het werk te gaan. Activering naar werk is de afgelopen decennia één van de speerpunten van het overheidsbeleid. Na een periode waarin vooral de beschermende functie van het stelsel van sociale zekerheid centraal stond, is in het denken over sociale zekerheid in de loop van de jaren ' 80 een omslag te herkennen (Teulings e.a., 1997). Die omslag gaat gepaard met de maatschappelijke constatering dat het aantal gebruikers van sociale voorzieningen problematisch is. In eerste instantie omdat de verhouding tussen het aantal actieven en inactieven financieel economisch te zware lasten met zich mee zou brengen. Daarnaast heeft die constatering een morele dimensie: het aantal mensen dat niet werkt zou onverantwoord groot zijn gezien de betekenis van arbeid voor maatschappelijke integratie van het individu.

Alhoewel de beschermende doelstelling van het stelsel van sociale zekerheid niet geheel van de agenda is verdwenen, staat op die beleidsagenda activering, dat wil zeggen het stimuleren van arbeidsdeelname centraal. Vanuit die beleidsagenda kunnen we niet anders dan constateren dat het werk van verzekeringsartsen effectief is. De logica van de verzekeringsgeneeskundige praktijk 'produceert' immers verantwoordelijke werknemers, en hoewel dat niet bij iedereen succesvol is, zien we tegelijkertijd dat een groot deel van de zieke cliënten zich vrij onproblematisch voegt in de logica van de praktijk.

Maar de verzekeringsgeneeskundige praktijk is niet alleen reagens, die beleidsactivering van de maatschappelijke agenda absorbeert. De verzekeringsgeneeskundige praktijk 
produceert niet alleen verantwoordelijke werknemers, tegelijkertijd levert ze een bijdrage aan de normalisatie van werk als beste manier om maatschappelijke integratie te bevorderent. Met andere woorden, de verzekeringsgeneeskundige praktijk is evenzeer producent van de norm dat werken als hoogste goed beschouwd moet worden. Met de productie van verantwoordelijke cliênten, mensen die zelf hun best doen om hun werk te hervatten, wordt, als keerzijde van de zelfde medaille, de norm geproduceerd, dat werken belangrijk is.

Vanuit bovengenoemde beleidsagenda gezien is de productie van een dergelijke norm eveneens productief. De verzekeringsgeneeskundige praktijk stimuleert niet alleen arbeidsdeelname, maar bestendigt eveneens de norm dat werken van belang is voor deelname aan het maatschappelijk leven. Dat arbeid in onze samenleving een belangrijke rol vervult, zullen weinigen betwisten. Desalniettemin kunnen we vragen stellen bij het risico dat dergelijke praktijken in zich dragen, namelijk dat aan arbeid het alleenrecht wordt toegeschreven bij het bevorderen van maatschappelijke integratie en dat arbeid altijd bevorderend is voor die integratic. Met name in banen aan de onderkant van de arbeidsmarkt valt te betwijfelen of arbeid een dergelijke bijdrage wel levert. In deze regionen van de arbeidsmarkt hebben banen vaak niet de positieve eigenschappen die aan arbeid in algemene zin worden toegeschreven. Bovendien is de rechtspositic, zeker gezien de opkomst van flexibele arbeidsovereenkomsten, daar dusdanig dat mensen weinig mogelijkheden hebben betere arbeidsomstandigheden af te dwingen. Op deze negatieve kanten van een sterke activeringspolitiek is door diverse auteurs in het kader van discussies over burgerschap uitvoerig gewezen (Van Stokkum, 1995: Van Gunsteren, 1992; Dercksen en Engbersen, 1992).

Dat brengt ons op een tweede overweging, van waaruit we de normatieve werking van de verzekeringsgeneeskundige praktijk kunnen bekijken. Het functioneren van die praktijk kunnen we ook benaderen vanuit de vraag wat de consequenties van de logica van de praktijk zijn voor individuele cliënten. In eerdere hoofdstukken heb ik laten zien dat de verzekeringsgeneeskundige praktijk normaliseert, dat wil zeggen cliēnten middels subtiele mechanismen van zelfcontrole aanzet tot een gedrag van 'verantwoordelijke' werknemers. Via die normalisering worden mensen gereïntegreerd in het arbeidsproces. Voor een redelijk groot deel van de zieke werknemers werkt dat, en betekent dat dat ze deel blijven nemen aan het arbeidsproces. In een samenleving waarin arbeid een belangrijke bijdrage heeft bij het mogelijk maken van maatschappelijke reintegratie, is dat positief. Voor een deel van de zieke werknemers zullen deze mogelijkheden om mee te blijven doen juist geschapen worden door activeringskarakter van de individuele bemiddeling. Voor hen vormt dat activeringskarakter met andere woorden het steuntje in de rug om te blijven werken of weer aan het werk te gaan.

Tegelijkertijd hebben we gezien dat die normalisering niet altijd slaagt. Mensen die zich niet gedragen als 'verantwoordelijke' werknemers, die hun situatie blijven beschrij- 
ven in termen van ziekte, krijgen problemen. Het traject dat deze mensen doorlopen is op basis van dit onderzoek niet precies aan te geven. Een deel verwerft steun van ofwel behandelend artsen ofwel hun werkgevers om hun claim niet te kunnen werken hard te maken. $\mathrm{Zij}$ behouden hun recht op uitkering. maar worden tegelijkertijd vaak als onwillig, ongemotiveerd etc. gebrandmerkt. In andere gevallen worden mensen tegen hun wil, met behulp van formele machtsmiddelen en vaak na relatief lange periode van ziekte weer aan het werk gestuurd. Verzekeringsartsen zelf wijzen echter op de ineffectiviteit van dergelijke dwang op lange termijn (zie h4). Mensen melden zich opnieuw ziek, en ook hier spelen oordelen als onwilligheid en ongemotiveerdheid een rol. Los van de vraag hoe het traject er precies uit ziet, is aannemelijk dat mensen die niet in staat zijn om mee te denken in het vertoog van activering en eigen verantwoordelijkheid het moeilijk krijgen.

De vraag waarom sommige mensen er niet in (willen?) slagen mee te komen in het opnemen van de eigen verantwoordelijkheid is niet eenvoudig te beantwoorden. We kunnen ons wel afvragen of de ideologie van de eigen verantwoordelijkheid voor iedereen betere kansen biedt. Is het inderdaad zo dat iedereen beter af is, als hij of zij via de mogelijkheden die het werk biedt mee te doen in het maatschappelijke leven? Is de belofte van zelfstandigheid beter dan de afhankeliikheid van een uitkering?

De realiteit van de arbeidsmarkt gebiedt ons op de eerste plaats rekening te houden met het feit dat volledige arbeidsdeelname op dit moment niet gerealiseerd wordt. Dat betekent dat een deel van de mensen aangewezen zal blijven op een uitkering. Deze mensen komen niet alleen in financieel opzicht in een marginale positie terecht. De kansen op een plaats op de arbeidsmarkt nemen af, naarmate een periode van uitval langer duurt (Teulings e.a., 1997). In een tijd waarin arbeid als voorwaarde geldt voor maatschappelijke participatie, betekent dat sociaal isolement en uitsluiting. Om die positie van sociaal isolement te doorbreken zouden ze aan het werk moeten, maar dat is problematisch. Bovendien gaat de positie van uitkeringsafhankelijkheid in toenemende mate gepaard met een morele veroordeling. Een situatie van uitkeringsafhankelijkheid kenmerkt zich niet alleen door een financieel geringe mogelijkheden, "maar ook door een maatschappelijk gezien weinig gerespecteerde positie, geringe perspectieven en het gevaar van het verlies van zelfrespect" (Van der Veen 1990, 199). Juist de nadruk op de eigen verantwoordelijkheid in de activeringsgedachte geeft ruimte aan deze morele veroordeling. In zekere zin leidt het benadrukken van die eigen verantwoordelijkheid immers tot het idee dat deelname aan het arbeidsproces iets is dat je zelf in de hand hebt. De positie voor een wellicht kleinere groep mensen (alhoewel de resultaten van het activeringsbeleid in cijfermatige zin nog niet duidelijk zijn) is daarmee des te schrijnender.

Een tweede groep mensen waar we ons de vraag kunnen stellen of activering door een beroep op de eigen verantwoordelijkheid een aantrekkelijk alternatief is, zijn degenen die 
aangewezen zijn op de onderste regionen van de arbeidsmarkt. Gezien de geringe ontplooiingskansen die het werk hier bieden, het vaak zware lichamelijke karakter van het werk en de financieel niet meest florissante posities kunnen we ons afvragen wat activering deze mensen brengt. Niet ondenkbaar is dat juist voor deze groep mensen de impliciete dwang in het activeringsbeleid de afhankelijkheid vergroot. Zeker omdat werkgevers in deze regionen van de arbeidsmarkt niet de meest enthousiaste aanhangers van sociaal-preventieve verzuimbegeleiding zijn (Mudde, 1995). Met andere woorden dit zijn niet direct de meest aangewezen plekken op de arbeidsmarkt, waar sprake is van een gelijkwaardige werknemer-werkgeverrelatie. De vraag is dan ook of het voor deze mensen aantrekkelijk is om 'ziekte' als tijdelijke ontsnappingsroute op te geven, en in te ruilen voor het activeringsdenken.

Met het stimuleren van mensen om hun werk te hervatten wordt in de verzekeringsgeneeskundige praktijk tegelijkertijd de norm dat werken van groot belang is voor maatschappelijke integratie ge(re)produceerd. Die activering creěert, zeker in een tijd waarin het stimuleren van arbeidsparticipatie hoog op de maatschappelijke agenda staat, voor een groot deel van de mensen kansen. Tegelijkertijd brengt de normaliserende werking van de verzekeringsgeneeskundige praktijk een deel van de zieke werknemers, juist door de reproductie van de norm dat werken van belang is voor maatschappelijke integratie, in een moeilijk en wellicht uitzichtloze situatie.

\section{Besluit}

Sinds de uitvoering van dit onderzoek is de wet- en regelgeving op het terrein van (kortdurende) arbeidsongeschiktheid gewijzigd. Middels de in 1996 ingevoerde Wet Uitbreiding Loondoorbetalingsverplichting bij Ziekte (WULBZ) dragen werkgevers de financiele risico's van verzuim van zieke werknemers gedurende het eerste ziektejaar. Ook de begeleiding en controle van zieke werknemers is primair de verantwoordelijkheid van werkgevers. Voor de uitvoering van deze taken dienen zij een gecertificeerde deskundige dienst (Arbodienst) in te schakelen. Welke taken deze dienst in het kader van de sociaalmedische begeleiding precies voor de werkgever uitvoert, wordt middels een contract tussen werkgever en Arbodienst vastgelegd.

Gezien deze wijzigingen wordt de vraag opportuun wat de in dit onderzoek gevonden resultaten nog voor geldigheid hebben. Ondanks de doorgevoerde wijzigingen kan beargumenteerd worden dat deze resultaten wel degelijk relevant zijn. Enerzijds omdat er naast de veranderingen ook grote overeenkomsten zijn tussen het dagelijks werk dat verzekeringsartsen ten tijde van het onderzoek verrichtten en het werk dat bedrijfsartsen binnen de Arbodiensten in de nieuwe situatie uitvoeren. Anderzijds omdat de normatieve 
dilemma's die samenhangen met het werk van verzekeringsartsen geenszins verdwenen zijn.

Op de eerste plaats vertoont het dagelijkse werk van de huidige bedrijfsartsen belangrijke overeenkomsten met het werk van de verzekeringsartsen in de oude situatie. Werknemers die zich hebben ziek gemeld brengen een bezoek aan de bedrijfsarts van de Arbodienst. Volgens de formele richtlijnen heeft dit gesprek zowel een controlerend als een begeleidend karakter. Die begeleiding bestaat dan uit het stimuleren van een reïntegratie in eigen of ander werk. Die reintegratie heeft, formeel gezien, meer aandacht gekregen. Vanuit de overheid worden werkgevers en Arbodiensten namelijk gestimuleerd om de mogelijkheden voor reïntegratie niet alleen bij de eigen werkgever, maar ook bij andere werkgevers te onderzoeken.

Met de nadruk die ook in de nieuwe situatie ligt op reintegratie, lijkt het eveneens aannemelijk dat bedrijfsartsen zich in de begeleiding van zieke werknemers oriënteren op cen probleemdefinitie die relatie houdt met de werkhervatting en niet op de eerste plaats op een op ziekte georiënteerde definitie. Een domeinafbakening ten opzichte van behandelend artsen volgens deze lijn, zal in de praktijk dan ook nog wel terug te vinden zijn.

Naast de gesprekken met zieke werknemers, houden bedrijfsartsen zich, afhankelijk van het contract dat werkgevers met de Arbodienst hebben afgesloten, bezig met begeleiding van werkgevers bij het voeren van een verzuimbeleid binnen de instelling. Het voeren van een verzuimbeleid is in de nieuwe regelgeving een verplichting van de werkgever. Die begeleiding vindt nog steeds ten dele plaats in de zogenaamde SMT's.

Discussies in (medische) tijdschriften, die ten tijde van de doorvoering van de veranderingen opnieuw zijn opgelaaid, laten zien dat de verhouding tussen verzekeringsartsen, bedrijfsartsen en behandelend artsen nog steeds onderwerp van debat is. De positie van bedrijfsartsen binnen de Arbodienst maakt bedrijfsartsen volgens velen meer afhankelijk van werkgevers, dan de verzekeringsartsen in de oude situatie dat waren. De samenwerking en informatie-uitwisseling tussen bedrijfsartsen en behandelend artsen wordt daar eerder door bemoeilijkt dan verbeterd, omdat het risico dat vertrouwelijke informatie over patiënten in handen van derden (werkgevers) komt wordt vergroot (zie ook h2).

Bedrijfsartsen houden zich in de nieuwe situatie dus nog steeds bezig met individuele verzuimbegeleiding en -controle, het afbakenen van hun taken van die van behandelend artsen en met begeleiding van werkgevers/bedrijven bij het ontwikkelen van een verzuimbeleid. De nadruk bij deze activiteiten ligt niet op het vaststellen van ziekte, maar op het reïntegreren van zieke werknemers. Bedrijfsartsen opereren met andere woorden nog steeds in een afhankelijkheidsnetwerk, waarin werkgevers, werknemers en behandelend artsen een positie in hebben.

Zowel de inzet of doelstelling, de probleemdefiniëring als de configuratie van actoren betrokken bij de arbeidsongeschiktheidsbegeleiding en -beoordeling staat nog voor een groot deel overeind. Belangrijk verschil is de aard van de relatie tussen bedrijfsarts en 
werkgever. Op de eerste plaats is de werkgever nu (via de Arbodienst) opdrachtgever van de bedrijfsarts, waar de positie van verzekeringsartsen in de oude situatie onafhankelijk was. Ten tweede zijn de taken die bedrijfsartsen uitvoeren voor werkgevers vastgelegd in contracten tussen werkgever en Arbodienst, en heeft de werkgever dus een stem bij het bepalen van de begeleidingstaken die door de Arbodienst worden uitgevoerd.

Het lijkt aannemelijk dat deze verandering in de aard van de relatie tussen werkgever en bedrijfsarts consequenties heeft. Binnen de logica van de verzekeringsgeneeskundige praktijk hebben we immers gezien dat het reïntegreren van mensen slaagt door het precaire evenwicht in de afhankelijkheidsrelaties tussen de verschillende actoren. Om dat evenwicht in stand te houden, verzetten verzekeringsartsen veel werk om (onder andere) werkgevers te motiveren en te activeren om een open werkrelatic te onderhouden met hun zieke werknemers, waardoor overleg over werkaanpassingen mogelijk wordt. Het is de vraag of de ruimte die bedrijfsartsen in de nieuwe situatie hebben voldoende groot is om werkgevers op deze wijze te motiveren. Onderzoek onder bedrijfsartsen duidt eerder op het tegendeel (Willems, 1998). Bedrijfsartsen geven desgevraagd aan meer druk te ervaren vanuit werkgevers, waardoor een goede begeleiding van werknemers belemmerd wordt.

In wet- en regelgeving lijken een aantal zaken die in de praktijk reeds op vrijwillige basis werden uitgevoerd nu verplicht te worden gesteld. Wet- en regelgeving lijkt daarmee ondersteuning te geven aan een aantal ontwikkelingen in de praktijk. Het is echter de vraag of die conclusie gerechtvaardigd is. Verzekeringsartsen slaagden er redelijk goed in om bijvoorbeeld werkgevers aan te spreken op hun verantwoordelijkheid bij het oplossen van belemmeringen die werknemers ondervonden bij het uitvoeren van hun werkzaamheden. Nu werkgevers deze verantwoordelijkheid formeel opgelegd hebben gekregen, komen er steeds meer signalen uit de praktijk dat ze die verantwoordelijkheid in zekere zin afwentelen. Uit recent onderzoek onder bedrijfsartsen (Willems, 1998) komt naar voren dat bedrijfsartsen van mening zijn dat er in toenemende mate sprake is van risicoselectie door werkgevers, een afnemende aandacht voor preventie en dat de druk op werknemers is vergroot. Het herverzekeren van de loondoorbetalingsplicht bij particuliere verzekeringsmaatschappijen zou daar wel eens de oorzaak van kunnen zijn. Dit leidt tot de wat paradoxale conclusie dat het formaliseren van zaken die in de uitvoering reeds op vrijwillige basis werden uitgevoerd, deze zaken niet zozeer steunt als wel ondermijnt.

Een tweede aspect dat we in de vergelijking van de oude en nieuwe situatie kunnen betrekken is de normativiteit van het praktisch handelen. Gezien de grote overeenkomsten tussen de positie van bedrijfsartsen in de nieuwe en de positie van verzekeringsartsen in de oude situatie lijkt het niet aannemelijk dat de normativiteit van deze praktijk, de impliciete normen ten aanzien van de vraag hoe op een 'goede' manier om te gaan met arbeidsongeschiktheid, van richting veranderd is. Ook in de nieuwe situatie is het 
werk van bedrijfsartsen gericht op het stimuleren en activeren van zieke werknemers om hun werk weer te hervatten. Alhoewel de precieze patronen in de onderhandeling tussen zieke werknemers en bedrijfsartsen wellicht veranderd zijn, lijkt het evenmin aannemelijk dat deze gesprekken een volledig andere opzet hebben dan in de oude situatie. Gezien het belang dat wordt gehecht aan reintegratie en activering, is het waarschijnlijk dat de uitvoeringspraktijk nog steeds zowel 'verantwoordelijke' werknemers produceert als de norm dat werken een goede manier is om maatschappelijke integratie te bevorderen. Beide hebben zoals gezegd duidelijk hun positieve kanten, maar dragen tegelijkertijd risico's in zich, met name voor mensen die moeite hebben om mee te doen in het activeringsvertoog. Zolang die risico's klein blijven, kunnen we spreken over een redelijke balans in het stelsel.

De bovengenoemde signalen over de opstelling van (sommige) werkgevers leiden echter tot vraag of de positieve kanten van activering en de risico's die dat meebrengt voor mensen die onder aan of buiten de arbeidsmarkt raken, niet uit balans zijn geraakt. De kansen op uitsluiting van werk voor mensen die toch al geen sterke positie hebben op de arbeidsmarkt zouden wel eens vergroot kunnen zijn, doordat bedrijfsartsen hun invloed op werkgevers dreigen te verliezen. Een verandering in een stelsel van sociale zekerheid, waarin de positie van de zwaksten in de samenleving verslechtert, kunnen we toch moeilijk als een verbetering zien.

Het inzicht in de logica van de verzekeringsgeneeskundige praktijk maakt ons opmerkzaam op de precaire verhoudingen rondom de arbeidsongeschiktheidsbegeleiding en -beoordeling. Dat inzicht geeft ons handvatten om een voorzichtige inschatting te maken van de effecten die de nieuwe maatregelen kunnen hebben. Het lijkt erop dat de redelijk evenwichtige situatie van een aantal jaar geleden, uit balans dreigt te raken. Om vast te stellen of dat daadwerkelijk zo is, zal echter opnieuw onderzoek moeten worden verricht.

\section{Noten}

1. Dat wil niet zeggen dat mensen die een beroep doen op de ziektewet niet arbeidsongeschikt zijn in de betekenis dat ze door ziekte niet kunnen werken. Mensen die een beroep doen op de ziektewet zullen hun toestand wel als zodanig definiêren. In de verzekeringsgeneeskundige praktijk wordt dat echter niet getoetst, maar worden mensen die (nog) niet werken en waar de ziektewet doorloopt (niet expliciet is stopgezet) arbeidsongeschikt genoemd.

2. Overigens zegt dat meer over het 'standaardbeeld van medische expertise, dan over de verzekeringsgeneeskunde. Ook binnen andere geneeskundige (sub)disciplines wijkt het praktisch handelen af van deze standaardopvatting (Mol en Van Lieshout, 1989; Mol en Berg, 1998). 
3. Met andere woorden, de vraag of behandelend artsen zich buiten de spreekkamer daadwerkelijk zo gedragen is niet aan de orde. Hetgeen niet wegneemt dat die positionering in de contacten tussen bijvoorbeeld cliënten en behandelend artsen een handelingsoriēntatie vormt voor cliënten. Die identiteitsconstruetie van behandelend artsen in de verzekeringsgeneeskundige praktijk nemen cliënten mee naar de spreekkamer van de behandelend arts, om daar in de interactic met tussen behandelend artsen en cliênten opnieuw haar specifieke bij de interactie behorende gestalte aan te nemen. Dat geldt tevens voor de wijze waarop in de verzekeringsgeneeskundige praktijk onderscheidt gemaakt wordt tussen verschillende identiteiten van de cliênt.

4. Vergelijk Rose (1996), instituties creèren door hun in steeds grotere getale aanwezig zijn een psychologisch mensbeeld. 



\section{Literatuur}

Abbot, A. (1988) The system of professions; An essay on the division of expert labour. Chicago: The university of Chicago Press.

Asscher- Vonk, I.P., Bouwens, W.H.C.M., Jacobs- De Klerk, C.C.A.M., Monster, W.C. en Sparrius, C.F. (1997) De zieke werknemer. Deventer: Kluwer.

Beek, J.L.M. van der (1974) De mystificerende rol van de WAO in de psychiatrie. Arts en Sociale Verzekering, 12, 61-63.

Berg, S.A. van den, Kerkhoff, A.H.M. (1994) Artsen in niet-curatieve functies en beroepen, Tijdschrift voor Sociale gezondheidszorg, 7, 385-391.

Berg, M. (1992) The construction of medical disposals medical sociology and medical problem solving in practice, Sociology of Health and Illness, 14, 2, 151-180.

Berg, M. (1997) Rationalizing Medical Work: decision-support techniques and medical practices. Cambridge: MIT Press.

Boer, W.E.L. (1988) Beoordeling, begeleiding en preventie in de sociale verzekeringsgeneeskunde, Medisch Contact, 43, 1597-1600.

Boer, W.E.L. (1991) Het verzekeringsgeneeskundig beoordelingsgesprek. Zeist: BVG.

Boer, W.E.L. (1992) Argumentatieve claimbeoordeling deel I: de claim. Tijdschrift voor Verzekeringsgeneeskunde, 30, 110-114.

Boer, W.E.L., Giezen, A.M., Josée, L.H., Wieten, H., Til, M.J. van, Moolhuizen, E., Geldermans, W. Kieft, L.C. van de, Beldhuis, A. (1995) Gegevensoverdracht van arbodienst naar bedrijfsvereniging, Tijdschrift voor bedrijfs- en verzekeringsgeneeskunde, 2 , 46-50.

Bont, A. de, Meus, C., Hazelaar, G. (1998) Stoornissen, beperkingen en handicaps in de uitvoering; over verschillen in implementatie, interpretatie en de uitvoering van de richtlijn medisch arbeidsongeschiktheidscriterium, geillustreerd aan de hand van de problematiek bij ME. Zoetermeer: Ctsv. 
BVG (1992) Alert; een handleiding voor begeleiding op individueel niveau als onderdeel van een integraal verzuimbeleid. Zeist: BVG.

Caljé, K. (1993) Explosie WAO: "zo ontstond een klimaat van ga je gang maar", NRChandelsblad, 8 april 1993.

Collins, H.M. (1985) Changing Order; replication and Induction in Scientific Practice. London: Sage Publications.

Combé, L. de la, Streng, J.C. (1991) Artsen en Arbeidsongeschiktheid, Medisch Contact, 49, 46, 1477-1479.

Croon, N.H.Th. (1988) NVVG: garantie voor kwaliteit, Tijdschrift voor verzekeringsgeneeskunde 26, 166-167.

Croon, N.H.Th., Langius, S.W.Th. (1993) Arbeid en gezondheid; een studie van de verzekeringsgeneeskundige praktijk bij de bedrijfsverenigingen. Proefschrift UVA.

Croon, N.H.Th., Boer, W.E.L. de (1994) Informatie-uitwisseling tussen deskundige diensten en sv-organen, Tijdschrift voor bedrijfs- en verzekeringsgeneeskunde, 2, 28-31.

Cuypers, J.J.F.M., Eijndhoven, A.J.B. van en Theloesen, P.H.M. (1992) Samenwerking van artsen bij werkhervatting, Nederlands Tijdschrift voor Geneeskunde, 136, 22, 10541057.

Denzin, N.K., Lincoln, Y.S (eds.) (1994) Handbook of qualitative research. Thousand Oaks: Sage publications.

Dercksen, W.J., Engbersen, G. (1992) Arbeid en sociaal Burgerschap. In: Gunsteren, H.R. van (red) Burgerschap in praktijken. WRR.

Eck, M.M.A. van (1990) Het beslissingsproces van de medische functie bij het GAK. Proefschrift UVA.

Festen, H. (1970) Organisatie van de gezondheidszorg en invaliditeit. Arts en Sociale Verzekering, 8, 117-125.

Garfinkel, H. (1967) Studies in Ethnomethodology. Prentice-Hall. 
Gentis, A.F.J. (1972) Medische aspecten van de arbeidsongeschiktheidsverzekering, Arts en Sociale Verzekering, 10, 90-91.

Greveling, G.W., Waanders, W.J. (1995) Ziekteverzuim en arbeidsongeschiktheid; 100 praktische vragen voor de werkgever. Delwel Uitgeverij B.V.

Gunsteren, H.R. van (1992) Eigentijds burgerschap. WRR.

Harré, R. (1979) Social Being. Oxford: Basil Blackwell Publishers.

Herngreen, H. (1985) Kritische reflecties op het verzekeringsgeneeskundig referentiekader, Tijdschrift voor verzekeringsgeneeskunde, 23, 188-192.

Hilverinck, H.G. (1978) Arbeidsongeschikt of arbeid ongeschikt. Arts en sociale verzekering, 16, 55-60.

Horstman, K. (1996) Verzekerd leven; Artsen en levensverzekeringsmaatschappijen 18801920. Amsterdam: Babylon- De Geus.

Hunfeld, G. (1984) Arbeidsongeschiktheid vroeger en nu, Tijdschrift voor Sociale Geneeskunde/ Arts en Sociale Verzekering, 62/22, 523-528.

Josten, J.G.J.E. (1974) WAO - doel en verwerkelijking, Arts en sociale verzekering, 12 , $11-17$.

Josten, J.G.J.E. (1978) Tussen zorg en zelfstandigheid: een samenleving op schaal, Arts en sociale verzekering, 16, 42-45.

Kaiser, C.P. (1992) Het verzekeringsgeneeskundig handelen en de verzuimduur; een studie naar het handelen en de taakopvatting van verzekeringsgeneeskundigen en met verzekeringsgeneeskandige taken belaste bedrijfsartsen in de regio Zuid-Limburg. Maastricht: universitaire pers Maastricht (proefschrift)

Knepper, S. (1989) Het onderzoek naar beperkingen van vaardigheden in relatie tot ziekte of gebreken, Sociaal recht, 75-78.

KNMG (1987) Procedure verandering informatieverstrekking, Medisch Contact, 42, 382 383 . 
KNMG (1991) Herziening van het Besluit en Rapport inzake Geneeskundige Verklaringen, Intercollegiale Informatie, Medische Informatie (het 'groene boekje'), Medisch Contact, 46, 36, 1053-1062.

KNMG (1995) Richtlijnen inzake het omgaan met medische gegevens. Utrecht: KNMG.

KNMG (1996) Behandeling en controle: scheiding of combinatie? Een blik over de grenzen; symposium 25 april, Medisch Contact, 51, 16, 562-563.

Komter, A. (1983) De onmacht van het getal, Kennis en methode, 3, 202-226.

Latour, B. (1987) Science in Action. Milton Keynes: Open University Press.

Latour, B. (1988) The Pasteurization of France. Harvard University Press.

Levi, R.H. (1994) Ziekmakend, Medisch Contact, 49, 6, 184.

Livingstone, E. (1987) Making sense of ethnomethodology, London: Routledge \& Kegan Paul.

Loenen, A.L.W. van (1997) Van chronische psychiatrische patiënt naar brave burger? Over de moraal van psychische rehabilitatie, Maandblad Geestelijke Volksgezondheid, 52, 751-761.

Lupton, D. (1995) The imperative of health; public health and the regulated body. London: Sage Publications.

Lynch, M. (1985) Art and Artifact in Laboratory Science; a study of shop work and shop talk in a research laboratory. London: Routledge \& Kegan Paul.

Meershoek, A.M. (1993) Falende poortwachters met een goed geweten? Verzekeringsgeneeskundigen en het debat over de uitvoering van de arbeidsongeschiktheidsregelingen, Gezondheid; theorie en praktijk, 1, 2, 156-173.

Mertens, P.J.J. (1974) Openingsrede studiedagen sociale verzekeringsgeneeskunde, Arts en sociale verzekering, $12,26-32$. 
Mol, A. en Lieshout, P. van (1989) Ziek is het woond niet; Medicalisering, normalisering en de veranderende taal van de huisartsgeneeskande en geestelijke gezondheidszorg. 1945-1985. Nijmegen: SUN.

Mol, A. (1993) Van wie is de theorie? Gezondheid; theorie en praktijk, 1, 5-16.

Mol, A. en Berg, M. (1994) Principles and practices of medicine; the co-existence of various Anemias, Culture, Medicine and Psychiatry, 18, 247-265.

Mol, A. (1999) The body multiple; ontology in medical practice. (forthcoming)

Mol, A. en Berg, M. (1998) Differences in Medecine: an introduction. In: Berg, M., Mol, A. (eds.) Differences in Medecine; unraveling practice, techniques, and bodies. Durham: Duke University Press.

Mudde, E.C. (1995) Ziek in de zin der wet; de interpretatie van ziekteverzuim door verzekeringsgeneeskundigen en rapporteurs. Den Haag: Sdu.

Post, D. (1994) Samenwerking stimuleren tussen sociale geneeskunde en curatieve sector; werken aan hetzelfde doel, Medisch Contact, 49, 38, 1179-1182.

Rapportage Arbeidsmarkt zorgsector (1997). Utrecht: Nivel, NZi en OSA.

Razenberg, P.P.A. (1992) Verzekeringsgeneeskundige oordeelsvorming; inzicht in de praktijk. Proefschrift UVA.

Robroek, F. (1998) Ziektewet; onderzoeken tonen negatieve effecten privatisering aan, Arbeid en Milieu, 16-17.

Rose, N. (1993) Towards a critical sociology of freedom. London: Goldsmiths College, Inaugural Lecture.

Rose, N. (1996) Inventing our selves; Psychology, power, and personhood. Cambridge: university press.

Saan, M. (1981) Nabeschouwingen over de studiedagen Sociale Verzekeringsgeneeskunde 1981, Tijdschrift voor Sociale Geneeskundel Arts en Sociale Verzekering, 59/19, 692694. 
Schuyt, C.J.M. (1986) Filosofie van de sociale wetenschappen. Leiden: Nijhoff.

SCP (1996) Sociaal en Cultureel rapport 1996. Rijswijk: SCP.

Silverman, D. (1989) Communication and medical practice; social relations in the clinic, London: Sage publications.

Silverman, D. (1993) Interpreting qualitative data; methods for analysing talk, text and interaction. London: Sage publications.

Smits, E.L. (1988) 'Protocollen in de verzekeringsgeneeksunde: garantie voor kwaliteit', Tijdschrift voor verzekeringsgeneeskunde, 26, 164-166.

Spreeuwenberg, C. (1996) Scheiding van behandeling en controle, Medisch Contact, 51, 21, 695.

Steen, W.J. (1988) Protocollen in de verzekeringsgeneeskunde, Tijdschrift voor Verzekeringsgeneeskunde, 26, 168-171.

Stokkum, B. (1995) Zelfrespect boven werk. Beschouwingen over burgerschap en basisinkomen. In: Veen, R.J. van der, Pels, D. (red) Het basisinkomen; Sluitstuk van de verzorgingsstaat. Amterdam: Van Gennip.

Stone, D.A. (1979) Physicians as gatekeepers: Illness certification as rational device, Public Policy, 27, 2, 227-254.

Stone, D.A. (1984) The Disabled State. Philadelphia: Temple University Press.

Stüssgen, R.A.J. (1997) De nieuwe patiënt op weg naar autonomie. Amsterdam: Thesis Publishers.

Swaan, A. de (1983) De mens is de mens een zorg. Amsterdam: Bert Bakker.

Swaan, A. de (1990) The management of normality; critical essays in Health and welfare. London: Roudledge.

Teulings, C., Veen, R.J. van der, Trommel, W. (1997) Dilemma's van Sociale zekerheid; een analyse van 10 jaar herziening van het stelsel van sociale zekerheid, 's Gravenhage: Vuga. 
Timmer, M. (1985) Verzekeringsgeneeskundig referentiekader, Tijdschrift voor verzekeringsgeneeskunde, 23, 22-24.

Tweede kamer (1992) Parlementaire enquéte uitvoering sociale zekerheid, vergaderjaar 1992-1993, 22 730, nrs. 7-8. 's-Gravenhage: Sdu.

Veen, R.J. van der (1990) De sociale grensen van beleid; een ondersoek naar de uitwoering en effecten van het stelsel van sociale zekerheid, Leiden: Stenfert Kroese.

Veen, R.J. van der (1997) Uitvoering van beleid; een beschouwing over onderzoek naar de uitvoering van wet- en regelgeving in Nederland, Recht der werkelijkheid,2, 4-17.

Veerman, T.J. (1990) Ziekteverzuim: definities, termen, wetten. In: Smulders, P.G.W., Veerman, T.J. (red.) Handboek Ziekteverzuim; Gids voor de bedriffspraktijk.

Velema, W. (1991) De falende poortwachters van de WAO, Intermediair, 27, 37 (13 sept.), 10-17.

Weijel, J.A. (1970) De plaats van de psychotherapie in de sociale verzekering. Arts en Sociale Verzekering, 8, 3-8.

Weijel, J.A. (1973) Verzekeringsgeneeskunde nieuwe stijl, Arts en sociale verzekering, $11,21$.

Widdershoven, G.A.M. (1987) Handelen en rationaliteit; een systematisch overzicht van het denken van Wittgenstein, Merleau-Ponty, Gadamer en Habermas. Amsterdam: Boom.

Wilde R. (1992) Discipline en legende; de identiteit van de sociologie in Duitsland en de Verenigde Staten 1870-1930. Amsterdam: Van Gennip.

Willems, J.H.B.M. (1998) Privatisering van de ziektewet; het medisch draagvlak wordt kleiner, Medisch Contact, 53, 423-426.

Zaal, M.J. (1978) Meningen van GMD-cliënten, Arts en sociale verzekering, 16, 47-53. 



\section{Summary}

In the Netherlands, public programs of disability insurance have been the subject of political and public debate for over ten years. The foundation of the social security system as such, as well as its organization, are criticized in these debates. The work of physicians, however, has received little attention in these discussions. Their professional expertise seems to protect physicians from external interference; laymen - the general public as well as policy makers - seem to feel that they are not authorized to judge 'medical' work. The lack of attention for physicians' work is remarkable, because who is entitled to receive financial support and who is not, is determined - at least in part- in insurance physicians' daily practice. In the way decisions are made in practice, the boundary between those who are included and those who are excluded from sickness benefits is constructed. Therefore, insight into insurance physicians' practical work is important when addressing questions about the legitimacy and justice of the social security system.

The aim of this dissertation is to gain a clear understanding of the daily practice of physicians' illness certification for the Dutch Sickness Benefit Act. These insurance physicians are employed by social insurance companies in order to determine whether clients are entitled to financial support for loss of income due to illness or handicap. In this investigation of their daily practice, it is assumed that their activities are not so much a derivative of formal rules and professional expert knowledge, but that they have a 'logic' or 'ratio' of their own. Formal rules and expert knowledge are modified in practice due to the fact that participants in these practice make use of them and attribute meaning to them. In order to gain insight into this practical logic, the consultations between sick workers and insurance physicians are analyzed. In particular the way disability - that is partial or complete incapacity to work due to sickness or handicap - is constructed in these interactions, and the consequences of this construction process for the constitution of the different participants is explored.

Chapter one reviews research on insurance physicians' work, in particular on illness certification. Further, the theoretical perspective used in this study is introduced in relation to themes emerging from this literature. In chapter two the methodology and the research setting are introduced. Chapters three, four, and five, consist of analyses of empirical material, obtained by participatory observation of conversations between insurance physicians and clients during the medical examinations. Using excerpts of the conversations between physicians and clients, the order of the conversations is exposed. The analysis in chapter three clearly demonstrates how clients in the consultingroom are transformed into workers rather than patients. Not the illness and the medical treatment, but rather the limitations people are confronted with in doing their job, and the possibilities of working despite these limitations, are themes of the conversation. Thus, 
the sick person entering the consultingroom is transformed during the conversation into a person with a rehabilitation problem. Sick workers are encouraged to take their own responsibility for managing their problems, instead of relying on the doctor. Managing inability to work thus appears as a matter of internalized motivation and self-control, instead of external supervision and coercion.

Chapter four explores the order of the conversation by examining the way insurance physicians' work and responsibilities become demarcated from those of physicians working in a curative setting. Approaching the client as a worker more than as a patient, defines not only the identity of the client but also the insurance physician's identity. Insurance physicians claim jurisdiction in affairs of rehabilitation of sick workers. In doing so, they pacify possible interference in their work by physicians treating these sick workers. However, insurance physicians can not intervene directly in the work of curative physicians. In daily practice therefore, they try to convince the client of the demarcation they themselves maintain between their own focus on work versus the 'normal' physicians' emphasis on (treatment of) illness.

In chapter five, the position of the employer in the illness certification for the disability insurance program is investigated. By defining the problem in terms of the employee's abilities to work - either their regular job or other activities - employers become of crucial importance. In practice, the question whether an employee is unable to work appears not only to depend on the health problems of the employee, but also on the opportunities employers offer to their employees. Both the employee and employer are stimulated by the insurance physician to take responsibility in dealing with the problem of the employee. In this stimulation process, an ideal type of employer-employee relationship is constructed.

Chapter six draws the three empirical chapters together and relates them to the political legitimacy of Dutch public disability insurance programs. My research shows how in the conversations between clients and insurance physicians, clients are disciplined to become responsible, active and self-controlling employees. However, this disciplinary process provides opportunities as well as limitations for those people. For employees, to be able to return to their job is important, especially at a time when work is one of the most important means for social integration. However, the particular way in which the conversation is organized not only disciplines the client as an employee, it also establishes the norm of work as an important, or even the ultimate way of reaching a state of wellbeing. Reproducing this norm may lead to even further marginalization of the weakest groups on the labour market and may increase the risk of social exclusion of people who are not able to yield to this norm. 


\section{Curriculum vitae}

Agnes Meershoek is geboren op 25 februari 1967 te Losser. Op haar $7^{\text {th }}$ verhuisde zij naar Waalre, alwaar ze de lagere school voltooide. Van 1979-1985 doorliep zij het VWO aan het Sint Joris College te Eindhoven. Van 1985 tot 1990 studeerde zij Gezondheidswetenschappen, afstudeerrichting Theorie van de Gezondheidswetenschappen, aan de Universiteit van Maastricht. Van 1991-1995 was zij als Aio verbonden aan de vakgroep Gezondheidsethiek en Wijsbegeerte van diezelfde Universiteit. Sinds 1995 is zij bij dezelfde vakgroep werkzaam als universitair docent. 
AL MEER DAN EEN DECENNIUM zijn de Ziektewet en de WAO onderwerp van politieke en publieke debatten. Het functioneren van verzekeringsartsen wordt daarbij veelvuldig bekritiseerd, terwijl er weinig inzicht is in de wijze waarop zij in de praktijk arbeidsongeschiktheidsregelingen uitvoeren. In Weer aan het werk schetst Agnes Meershoek een gedetailleerd beeld van de gesprekken die artsen en zieke werknemers in het kader van de ziektewet voeren. Daarin wordt duidelijk dat niet het controleren van werknemers op ziekte, maar het aanspreken van werknemers op hun verantwoordelijkheid ten aanzien van de werkhervatting een cruciale rol speelt in de beoordelingsgesprekken. Tegelijkertijd laat zij zien dat ondanks het feit dat de beoordelingstaak van verzekeringsartsen wettelijk verankerd is, zij in de praktijk sterk afhankelijk zijn van de medewerking van onder andere behandelend artsen en werkgevers.

Het benadrukken van de eigen verantwoordelijkheid van werknemers creëert grenzen en mogelijkheden. In de conclusies wordt ingegaan op de vraag wat de werkwijze van verzekeringsartsen betekent voor individuele werknemers in het licht van de rechtvaardigheid van de arbeidsongeschiktheidsregelingen.

AGNES MEERSHOEK studeerde Gezondheidswetenschappen en is als universitair docent verbonden aan de Vakgroep Gezondheidsethiek en Wijsbegeerte van de Universiteit van Masstricht. 